\title{
THE MAKING OF MINJIAN \\ Yi Sha's Poetics and Poetry Activities
}

\author{
BY \\ YUJING LIANG \\ 梁余晶
}

A thesis

submitted to the Victoria University of Wellington in fulfilment of the requirements for the degree of

Doctor of Philosophy

Victoria University of Wellington

(2020) 


\section{Acknowledgements}

First and foremost, I would like to express my sincere gratitude to my supervisors, Dr. Luo Hui and Prof. Yiyan Wang, for their great patience, consistent support, and immense knowledge. As my primary supervisor, Dr. Luo provided sustained guidance, through numerous stimulating discussions, on the step-by-step development of my dissertation during the entire course of my research, while Prof. Wang, as my secondary supervisor, read through my complete draft and gave valuable and detailed feedback at the final stage. Without such helpful supervisors, I would not have achieved what I have today.

Besides my supervisors, I would like to thank the examiners of my dissertation: Duncan Campbell (Victoria University of Wellington), Dr. Lorraine Wong (University of Otago) and Prof. Dian Li (University of Arizona). What I learned from their erudition, expertise and critical insight will continue to inspire and benefit me in my future career.

I would like to thank the Chinese poet Yi Sha, the subject of my research, for accepting my interview request and kindly posting me a full carton of his poetry books from China, including many unofficial publications of limited circulation, which became important sources for my research.

My gratitude also goes to Prof. Maghiel van Crevel (Leiden University), who showed great interest in my research and acted as a helpful friend. We had many interesting and enjoyable conversations on Chinese poetry via email and Wechat.

Last but not the least, I would like to thank my family in China for their enormous support. My special thanks go to my mother and wife, who looked after my son for six years during my absence, a task more painstaking than completing a PhD. 


\begin{abstract}
This thesis investigates and critiques the notion of minjian through a case study of Yi Sha 伊沙 (b. 1966), a key figure of Chinese minjian poetry since its emergence in the 1990s. The term minjian became a focal point during the Panfeng Polemic in 1999, a most significant event in the history of contemporary Chinese poetry, when minjian was adopted to name one of the rivalling poetry groups and triggered an influential debate that shaped the contour of contemporary Chinese poetry in the ensuing decade. Minjian became a prevailing keyword on the Chinese poetry scene of the 2000s and inspired numerous unofficial poetry groups both in print and online. Though the term was frequently evoked and widely discussed, its connotations remained uncertain. Through my study of Yi Sha's poetry and poetry activities, I identify two major elements of minjian: colloquial poetics and unofficial stance. Both elements harken back to the classical tradition and had long manifested in contemporary Chinese poetry, yet it was not until the Panfeng Polemic when they were explicitly joined together to defend and define a group that was to be called the minjian poets. Yi Sha rose to prominence after the Panfeng Polemic and became an outstanding representative minjian poet largely responsible for the 'making' of minjian into a literary and cultural phenomenon. By combining discourse analysis with a critical biography of the poet, this research demonstrates the complex relationship that minjian poetry has with China's cultural establishment, the literary avant-garde, and world literature. I argue that Yi Sha's minjian is both a political stance and an aesthetic choice, with broad cultural and ideological repercussions; understanding the concept of minjian is imperative to the understanding of contemporary Chinese poetry.
\end{abstract}

Keywords: minjian, Yi Sha, colloquial poetics, unofficial stance, world poetry 


\section{Contents}

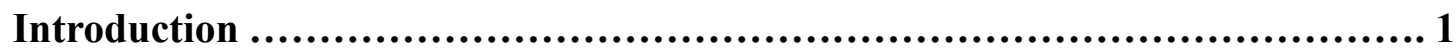

Chapter One Minjian in Polemics: From Panfeng to Yi Sha ....................21

1. Intellectual Poets vs. Colloquial Poets .................................... 22

2. The Panfeng Polemic: The Naming of Minjian ............................... 24

3. The Panfeng Polemic in Critical Assessment ............................ 27

4. Two Key Connotations of Minjian: Colloquial Poetics and Unofficial Stance .... 32

5. Yi Sha: The Making of a Minjian Hero ................................... 50

Chapter Two Minjian in Poetics: Yi Sha's Colloquial Poetry ................... 58

1. Colloquial Poetry Beyond Colloquialism: An Anti-Lyrical Poetics .............. 58

2. Yi Sha's Poetry: Profanity, Playfulness, Political Incorrectness ................ 73

3. Poetry of Facts: From 'Pre-Colloquial' to 'Post-Colloquial' ..................... 99

Chapter Three Minjian in the Digital Age: Yi Sha's Poetry Activities ......... 114

1. Poetry Jianghu: Performing the Unofficial in Digital Space ................. 115

2. Chang'an Poetry Festival: The Institutionalization of Minjian .................. 129

3. 'New Poetry Classics': Canonization of the Minjian Poetry .................... 139

Chapter Four Minjian in Global Context: Yi Sha and the World .............. 152

1. From Ginsberg to Bukowski: In Search of a Minjian Role Model ............. 153

2. From Bukowski to Tagore: Extending the Minjian Canon Through Translation. 170

3. Yi Sha's Poetry Overseas: Chinese Minjian Made in Australia ................. 175

4. Yi Sha in Translation: Minjian Brotherhood Through 'Gift-Exchange' ......... 184

5. Embracing Translatability: Minjian and World Poetry ........................189 
Appendix: Yi Sha Interviewed by Liang Yujing ............................... 209

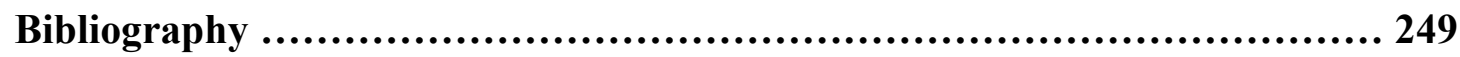




\section{Introduction}

This thesis is a study of contemporary Chinese poetry with a focus on the Minjian group through the trajectory of its outstanding representative, Yi Sha 伊沙 (b. 1966). It covers the time span of about twenty years since the emergence of the Minjian Poets in the 1990s. The main issues discussed include the concept of minjian, Yi Sha's colloquial poetics, Yi Sha's unofficial stance in his poetry activities, as well as Yi Sha's interactions with world poetry. This study will contribute to a better understanding of minjian as a major presence, a combination of both an aesthetic choice and a political stance, in contemporary Chinese poetry.

\section{Research Question}

The term minjian first appeared in the context of contemporary Chinese poetry during the Panfeng Polemic in 1999. The polemic involved two rival groups: the Zhishifenzi 知识分子 (Intellectual) poets and a cohort of poets loosely affiliated with Colloquial Poetry (kouyu shi 口语诗). During the Polemic, for want of a collective identity, the latter group was named the Minjian 民间 Poets. The name was accepted with enthusiasm and the poets quickly rallied around it. Since then, minjian has become a prevailing keyword on the Chinese poetry scene and inspired numerous unofficial poetry groups both online and offline, particularly during the 2000s. Though the term has been widely used and discussed, what minjian means for contemporary Chinese poetry remains open to question. Despite, and because of, the multiplicity in its meaning and usage, minjian has become a key term with regards to the development of contemporary Chinese poetry. This thesis, therefore, seek answers to the following twofold research questions: 1. What is the historical formation of minjian as a literary concept and how has it been re-imagined in contemporary Chinese poetics? 2. How has 
Yi Sha built his career as a representative Minjian Poet through his writing and literary activities and thus positioned himself at the forefront of the power dynamics and critical debates that shape contemporary Chinese poetry?

The word minjian contains two characters: $\min$ 民 (the people) and jian 间 (among), and it literally means 'among the people'. In popular usage, the word takes on multiple shades of meaning depending on the context. It has been variously translated as 'among the people', 'folk', 'unofficial', 'non-governmental', 'popular' and 'grassroots'. Attempts to define minjian can be found in essays by the poets Yu Jian 于坚 and Han Dong 韩东, two forerunners of the minjian group; but they both lack theoretical grounding and critical distance, and their arguments often slip into emotional venting or vague manifestos. Among the critics and scholars, discussions on minjian have often pivoted around its differences or similarities with zhishifenzi. Since zhishifenzi literally means 'intellectual', it is tempting to understand minjian as everything that is opposite to the intellectual.

The Minjian-Intellectual division was articulated in an early study in 1994 by the Chinese critic Chen Sihe 陈思和. ${ }^{1}$ In some ways anticipating the Panfeng Polemic, Chen identifies three dynamic forces - the official, the intellectual and minjianinteracting with each other in modern Chinese literary history. Chen's concept of minjian refers to the 'popular space' that, similar to Habermas's 'public sphere', resists the power of the nation-state. Chen's discussion relies heavily on examples from folk literature, which makes his minjian roughly identical to the traditional notion of the folk. ${ }^{2}$ Though sharing the same word minjian, the Minjian poetry that appeared in the late twentieth century can hardly be put into the category of folk literature, nor can it be considered part of Chen's popular space. Nearly all the Minjian Poets graduated from renowned universities in China. Their writings have little to do with folk literature.

\footnotetext{
${ }^{1}$ Chen Sihe 陈思和. 'Minjian de fuchen' 民间的浮沉 (The ups and downs of minjian). Shanghai wenxue 上海 文学 (Shanghai Literature), no. 1, 1994, p. 70.

2 Ibid, p. 68.
} 
Although the conception of minjian as folk literature does not seem applicable to the minjian poets that emerged after the Panfeng Polemic, Chen's study is relevant in that it puts minjian and zhishifenzi against the official and notes the dynamics of tension and resistance among the three forces. This resistance against the official is further highlighted in a recent study by Sebastian Veg, Minjian: The Rise of China's Grassroots Intellectuals. Veg points out that 'Because the term minjian takes its meaning from the historical dichotomy of $\min$ (people) and guan (officials), in the context of the People's Republic of China ('PRC') it is associated with anything that is "outside the system" (tizhi wai 体制外) - that is, any person, group, or activity that is not connected to a work unit (danwei 单位) in the official urban administrative system'. ${ }^{3}$ Veg further states that, in everyday speech, minjian often refers to a combination of three characteristics of people or institutions: independence from state income (self-funded), lack of approval by the state system (unofficial), and a low social marker (non-elite or grassroots). ${ }^{4}$ Veg's book focuses on a new figure of the intellectual that emerged in the 1990s - the grassroots or minjian intellectuals — who no longer indulged in 'sweeping discourses about culture, the nation, or democracy', but worked with 'vulnerable groups' and shared experiences with marginal realms of society. ${ }^{5}$ Veg's point that the intellectual taking on the stance of minjian is most helpful in understanding the formation and development of minjian poetry in recent decades.

It seems that during the Panfeng Polemic, minjian was indeed marked by an unofficial stance, as the minjian poets considered themselves independent and operating outside the official system. However, as Dian Li has pointed out, the so-called Minjian poetry is not essentially different from Intellectual poetry in poetic values, and both Minjian and Intellectual poets share a similar quality, that is, 'the independent spirit from the

\footnotetext{
3 Sebastian Veg. Minjian: The Rise of China's Grassroots Intellectuals. New York: Columbia University Press, 2019 , p. 7.

4 Ibid, p. 8.

5 Ibid, p. 7.
} 
official'. ${ }^{6}$ Maghiel van Crevel also defines both groups as 'avant-garde', which implies their difference from the writing influenced by the official Communist ideology. These observations have led to the assessment that the Panfeng Polemic was not a serious poetic debate, but a power game between two rival groups of poets.

Yet attempting to define or understand minjian vis-à-vis zhishifenzi can be risky because the two terms each have more complex connotations when used in the context of contemporary Chinese poetry, and therefore they should not be taken at face value. The two poetry groups and their respective poetics are far more sophisticated than what their names alone would suggest. Both 'intellectual' and 'minjian' are merely the names of the poetry groups, and it does not necessarily mean that members of one side are 'intellectuals' and of the other side are 'grassroots'. As poets who graduated from prestigious Chinese universities, both sides are in fact intellectuals. Their divergence lies in their aesthetic views. As I shall elaborate in Chapter One, the Minjian poets are all practitioners of various iterations of kouyu shi 口语诗 (Colloquial Poetry), and their poetics lean towards the 'earthly' rather than the 'elevated' end of van Crevel's aesthetic spectrum. ${ }^{7}$

In this study, I take departure from the Intellectual-Minjian dichotomy and re-examine the term minjian as both a cultural stance and an aesthetic orientation. This will involve moving beyond the Panfeng Polemic and placing the word minjian in the broader context of contemporary Chinese poetry, and observing its origins and evolution through a longer time span. Working under the assumption that minjian is not so much a literary concept articulated through theorisation, but rather a cultural position and a poetic ideal rooted in sustained practice, I propose to investigate the making of minjian through a case study of one of the most prominent and yet understudied Minjian

\footnotetext{
${ }^{6}$ Dian Li. 'Naming and Antinaming: Poetic Debate in Contemporary China'. In Christopher Lupke ed., New Perspectives on Contemporary Chinese Poetry. NY: Palgrave Macmillan, 2007, p. 190.

${ }^{7}$ Maghiel van Crevel. Chinese Poetry in Times of Mind, Mayhem and Money. Leiden: Brill, 2008, p. 25.
} 
Poets-Yi Sha.

This study is undertaken in the first-person, participatory mode. As I am a Chinese poet of the younger generation, Yi Sha has inspired me with his poetics for many years. Though I would not consider myself a steadfast follower of Yi Sha, my own aesthetic preferences do share some similarities with Yi Sha's. Meanwhile, I am a translator who has published a volume of the minjian poets' works in English translation, which signifies that, to some extent, I also participated in the making of minjian. My dual role as both an investigator and a participant is a challenge for me in conducting this study. Advantages and disadvantages coexist. On the one hand, my association with Yi Sha makes it easy for me to collect research data such as unofficial publications of a small circulation, which are usually difficult to obtain. On the other hand, I have to caution myself against being influenced by Yi Sha and keep a proper critical distance from my research subject. In my study, I have tried to maximise the advantages while avoiding the disadvantages.

\section{Focus and Scope}

Yi Sha is a key figure of Chinese minjian poetry since its emergence in the 1990s. Yi Sha rose to prominence after the Panfeng Polemic and became the most representative of the minjian poets. His work keeps evolving and contributing to the 'making' of minjian. In this study, I will trace Yi Sha's development from his formative years as a high school and university student in the 1980 s, to his most recent publications and literary activities, up to 2019. Through examining a broad range of literary texts and social activities, I will seek to provide a layered understanding of minjian as both a cultural position and an aesthetic ideal. By observing and chronicling a single poet over an extensive period of time, I will demonstrate that minjian does not just remain a theoretical concept, but also manifests and evolves as a distinctive poetic practice. I will also showcase the evident paradoxes in Yi Sha's life: an intellectual who defines his 
poetic practice in contradistinction to the 'intellectual poetry', a 'colloquial' poet whose translations of poetry seems somewhat less colloquial than earlier translations done in the 1920s by Zheng Zhenduo 郑振铎 (1898-1958), a poet whose creation of a nonofficial sphere for poetry mirrors the architecture of the official literary world. These paradoxes fully demonstrate the complexity of Yi Sha as a representative of the minjian concept.

Yi Sha's poetic career perfectly parallels the time span which I consider necessary for a full investigation of the emergence and evolution of minjian in contemporary Chinese poetry. The Colloquial Poets that emerged in the 1980s and were active for the most part of the 1990s, already exhibited certain characteristics and tendencies of minjian, though the term minjian had not yet been associated with these poets. They were loosely affiliated with each other through their mutual interest in 'Colloquial Poetry'. During the Panfeng Polemic in 1999, the term minjian appeared as the title of a group of Colloquial Poets. They immediately accepted this title and self-consciously cultivated their minjian qualities through their poetry, activities and a variety of publications online and in print, thus adding depth and complexity to this term and making it the most prevailing one on the Chinese poetry scene in the 2000s. In this study, I will trace the process in which Yi Sha initially identifies himself with Colloquial Poetry, then emerges as a key member of the minjian group after the Panfeng Polemic, and finally establishes himself as the most outstanding minjian poet through his sustained efforts to embody the spirit of minjian through his writing, translation, publishing, and social activities.

My discussion will focus on Yi Sha but will necessarily extend to other minjian or quasi-minjian poets, particularly Yu Jian, Shen Haobo 沈浩波, and Ouyang Yu 欧阳 昱. This is partly due to the fact that the minjian poets often acted as a group or collective in many settings, and partly due to the fact that the making of Yi Sha's poetic career has depended on some stellar friendships as well as some spectacular rivalries, all very much conditioned by the jianghu qualities of Chinese poetry circles, especially 
in the Internet age. As I shall explain in the chapters that follow, jianghu, which is originally a martial arts concept of sworn brotherhood operating on the margins of law and society, is useful for our understanding of the social aspects of minjian.

It should be pointed out that the term Minjian Poet, though primarily referring to those who participated in the Panfeng Polemic, is not a fixed list of poets that excludes those who did not participate. One distinctive feature of minjian is its inclusiveness. Any poet writing Colloquial Poetry or mainly engaging with unofficial poetry activities could claim to be a minjian poet. My study will mainly cover the poets with such characteristics who became active under the influence of the concept of minjian in the years following the Panfeng Polemic, primarily in the twenty-first century, such as Yi Sha, the Lower Body Poets and those who grew up under Yi Sha's influence. Though there are other poets with strong minjian characteristics such as migrant worker poets or peasant poets like Yu Xiuhua 余秀华, they are not the focus of my study. This also underpins the vitality and popularity of the term minjian, for it has fostered a sense of identity among a large number of Chinese poets.

My primary goal, through the case of study of Yi Sha, is to investigate how the term minjian is adopted, envisioned, conceptualised, and practised in contemporary Chinese poetry. There are a few other relevant terms that require elucidation in this study as well. For example, since Minjian Poetry was preceded by Colloquial Poetry in the 1980s, it is necessary to understand what Colloquial Poetry was and how it was developed to suit the needs and aspirations of Minjian Poetry. As a cultural stance, minjian is commonly believed to be unofficial. So what it means to be official, or unofficial, in contemporary Chinese cultural production also becomes a question that requires consideration.

\section{Literature Review}

Although the rise of the Minjian group is a relatively new phenomenon in contemporary 
Chinese poetry, scholars have produced a substantial body of research that touches upon either the Minjian Poets or some of their characteristics, in articles and in book form. Yet no one has provided a clear and convincing definition of minjian in contemporary Chinese poetry. As a representative of the minjian poetry group, Yi Sha has never been the focus of any monograph, or the subject of any extended academic study.

Maghiel van Crevel, a long-time researcher of contemporary Chinese poetry, published Chinese Poetry in Times of Mind, Mayhem and Money in 2008, which is a panoramic study of Chinese poetry since the 1980s, with a focus on the 'unofficial' and 'avantgarde' ${ }^{8}$ The book discusses nearly all the major avant-garde poets in China, but Yi Sha, though mentioned many times here and there as a representative of the Minjian Poets, does not get a full chapter. The book includes a full chapter about the Panfeng Polemic, with a detailed record of what was said and published during and after the polemic, and ends with a neutral attitude, proposing to treat it as a 'natural phenomenon'. 9 Van Crevel's monograph is a ground-breaking study of the complex situation of the Chinese poetry scene since the 1980s: he not only introduces the new trends of Chinese avantgarde poetry, then still unknown to the English academia, but also lays the theoretical foundation for future scholars in this field.

The importance of this book also lies in its effort to build a theoretical framework for the chaos of the contemporary Chinese poetry scene. Van Crevel insightfully uses a dichotomy to describe the aesthetic divergence in Chinese avant-garde poetry: the Elevated and the Earthly, and concludes that it is safe to say that across the contemporary period, the overall trend has been away from the Elevated and toward the

\footnotetext{
8 Though the word minjian only occasionally appears on its pages, it is easy to note that almost all the poets included in this book are major spokespersons of either the Intellectual or the Minjian group, with the exception of earlier poets Bei Dao 北岛, Yang Lian 杨炼 and Hai Zi 海子. The Intellectual Poets like Xi Chuan 西川, Wang Jiaxin 王家新 and Sun Wenbo 孙文波, as well as the Minjian Poets like Han Dong and Yu Jian, all find their own chapters in the book. Van Crevel also gives a full chapter to the Lower Body poets Yin Lichuan 尹丽川 and Shen Haobo, two young but prominent figures in the Lower Body group.

${ }^{9}$ Ibid, p. 450.
} 
Earthly'. ${ }^{10}$ This differentiation is important to my study of Minjian Poetry, because the term minjian, in poetics, is strongly related to the Earthly aesthetics in contemporary Chinese poetry as seen by van Crevel. The dichotomy of the Elevated and the Earthly will serve as the foundation for my analysis of the Minjian poetics.

Van Crevel notices that there is ambiguity in the use of the word 'official' 官方 among Chinese poets - they tend to desire to be institutionally official, while at the same time they are ashamed of being considered aesthetically official. ${ }^{11}$ This ambiguity also applies to the term minjian, which, when used in the context of contemporary poetry, does not have a fixed meaning, but should be understood on more than one level. Van Crevel's differentiation between how Chinese poets strategically position themselves on the ideological level and how they commit themselves on the aesthetic level will be helpful to my analysis of the Minjian Poets.

Apart from van Crevel, Michelle Yeh, in her article 'Anxiety \& Liberation: Notes on the Recent Chinese Poetry Scene', discusses the Panfeng Polemic and uses it as an example to illustrate the 'Chineseness complex' in contemporary Chinese poetry. According to Yeh, the Minjian Poets portrayed the Intellectual Poets as elitists and themselves as disadvantaged poets, who kept writing about native experiences. Yeh argues that the Polemic scandalized the poetry scene as a whole and 'probably did more damage than good to poetry'. ${ }^{12}$ Dian Li has also contributed an article that discusses the poetic debate between the Intellectual and the Minjian poets. In 'Naming and Antinaming: Poetic Debate in Contemporary China', Li analyses the deficiencies in the poetic claims of both the Intellectual and Minjian Poets, and argues that the two groups in essence share similar poetic values in many aspects: 'Misunderstanding and misreading of each other's positions are an integral part of any debate, and this debate

\footnotetext{
${ }_{10}$ Maghiel van Crevel. Chinese Poetry in Times of Mind, Mayhem and Money. Leiden: Brill, 2008, p. 26.

11 Ibid, p. 10.

12 Michelle Yeh. 'Anxiety \& Liberation: Notes on the Recent Chinese Poetry Scene'. World Literature Today, Vol. 81, No. 4, Inside China, July-August, 2007, p. 34.
} 
is no exception'. ${ }^{13}$ Li's article makes efforts to find out the cause of the Panfeng Polemic and his conclusion is a reasonable one. However, I think it is important to pay attention to both polemics and aesthetics in this case, because the Panfeng Polemic, as a complex and messy issue, was caused by more than one factor. This issue needs to be examined from the angles of both polemics and poetics.

Unlike van Crevel and Dian $\mathrm{Li}$, who focus on the poetic values of contemporary poets and their interactions, scholars like Michel Hockx, Michael Day and Heather Inwood approach this subject from another angle, that is, the interactions between poetry and media. Both Hockx and Day have produced research work on China's online poetry forums and poetry websites, which are exactly the places where the Minjian poetry grew into prosperity. In 'Virtual Chinese Literature: A Comparative Case Study of Online Poetry Communities', Hockx compares a Chinese online poetry community Zhongguo shiren wang 中国诗人网 (www.chinapoet.net) with an American one (www.everypoet.com), and concludes that 'Chinese web literature [...] has been the topic of intensive debate among Chinese critics and scholars of literature and it has literally made a name for itself among critics, publishers and book sellers in the larger print culture world, something that Western web literature has conspicuously failed to do'. ${ }^{14}$ Day's article 'Online Avant-Garde Poetry in China Today' is a detailed record and display of Chinese web poetry, including many minjian poetry websites such as Shi Jianghu 诗江湖 (Poetry jianghu) and Laji yundong luntan 垃圾运动论坛 (Trash movement forum). In this thesis, I will make a detailed examination of the website Poetry Jianghu, including its origin, characteristics and eventual shutdown, because that website served as the major space for the activities of Yi Sha and other Minjian Poets for most of the 2000s. Heather Inwood's book, Verse Going Viral: China's New Media Scenes, goes further along this road, and explores Chinese poetry on the web, in

\footnotetext{
13 Dian Li. 'Naming and Antinaming: Poetic Debate in Contemporary China.' In Christopher Lupke ed., New Perspectives on Contemporary Chinese Poetry. NY: Palgrave Macmillan, 2007, p. 200.

${ }^{14}$ Michel Hockx. 'Virtual Chinese Literature: A Comparative Case Study of Online Poetry Communities'. The China Quarterly, No. 183, Culture in the Contemporary PRC, September 2005, p. 691.
} 
print, on the stage and in the news during the initial years of this present century.

Other critics that touch upon this topic include John A. Crespi, who analyses the memory of the Cultural Revolution in the poems of Yu Jian and Sun Wenbo, ${ }^{15}$ and Ouyang Yu, who introduces the Lower Downs 下半身 (Lower body), the Rubbish 垃 圾诗派 (Trash poetry) and Low Poetry 低诗歌, and notices that 'contemporary Chinese poetry has unashamedly turned from the sublime and sacred to the vulgar and profane'. ${ }^{16}$ Ouyang's statement reveals there has been an Earthly poetics in contemporary Chinese poetry and that this trend has become more obvious in the age of the Internet. Yi Sha's poetry is also part of this trend. I will explore Yi Sha's poetics in my discussion of Colloquial Poetry.

Though Yi Sha has been overlooked by the current scholarship on the Minjian Poets, he is an important figure not only for his contribution to the poetics of Colloquial Poetry, but for his active engagement with unofficial poetry activities. Van Crevel's 'Rejective Poetry? Sound and Sense in Yi Sha' summarises Yi Sha's poetry as rejective on two levels: sound and sense. Van Crevel maintains that Yi Sha's work is worth rereading 'because of the concentrated, dense energy of his language and his capacity for observation and precise, defamiliarizing description, and most of all because of the dramatic tension generated by his ubiquitous irony' ${ }^{17}$ Heather Inwood's article 'Yi Sha: Running His Race in the "Ninth Lane"" introduces Yi Sha's literary works and addresses a number of core issues in his poetics and stances. Simon Patton and Tao Naikan published their translations of Yi Sha's short poems in 2008. In their introduction to that

\footnotetext{
15 John A. Crespi. 'Poetic Memory: Recalling the Cultural Revolution in the Poems of Yu Jian and Sun Wenbo.' In Christopher Lupke ed., New Perspectives on Contemporary Chinese Poetry. New York: Palgrave Macmillan, 2007, 165-183.

16 Ouyang Yu. 'Lower Downs, Rubbish and Low Poetry'. Otherland 194, Autumn 2009, p. 43. http://overland.org.au/?page id=931, accessed 23 October 2019.

17 Maghiel van Crevel. 'Rejective Poetry? Sound and Sense in Yi Sha'. In Maghiel van Crevel, Tian Yuan Tan, and Michel Hockx, eds. Text, Performance, and Gender in Chinese Literature and Music: Essay in Honor of Wilt Idema. Leiden and Boston: Brill, 2009, p. 412.
} 
publication, Starve the Poets: Selected Poems, they note that 'the stance Yi Sha has assumed as a poet is that of ordinary people rather than that of the elevated intellectual' and 'a curious feature of Yi Sha's early poetry is his insistence on illegitimacy'. ${ }^{18}$ Another book of translation was found in 2012, entitled Poems of Yi Sha, Shu Cai \& Yang Xie, translated and introduced by Ouyang Yu, who, in his introduction, traces the publication history of his translations of Yi Sha's poems and shows how popular they are among the English literary magazines. To date, there seems to be a disconnect between the significant exposure and popular acclaim that Yi Sha's poetry enjoys in the English-speaking literary circles and the apparent lack of scholarly treatment of his work. Although a typical Minjian Poet, Yi Sha's relationship with the foreign, including the foreign influence on him, and the spread of his poetry abroad, is an area that has never been studied before.

While English scholarship on minjian poetry tends to focus on polemics among the poets, Chinese scholarship pays more attention to poetics. In my research, I sought to bring these two aspects together to achieve a fuller understanding of minjian and Yi Sha. In Chinese academia, although there have not been any monographs on Yi Sha, he does draw the attention of influential critics like Tang Xin 唐欣, Luo Zhenya 罗振亚, Chen Zhongyi 陈仲义 and Deng Gen 邓艮. Their articles can be roughly divided into two groups. One group is about Yi Sha's poetry and poetics in general, while the other is about Yi Sha's individual poems. In general, the research to date focuses on what have come to be seen as the defining characteristics of Yi Sha's work: postmodern tendencies, irony, parody, comic spirit, deconstruction, colloquialism, everyday life and anti-culture. Chen Zhongyi examines the postmodern features in Yi Sha's poetry: decentralisation, anti-sublimity, anti-authority and intertextuality, and concludes that, under the camouflage of deconstruction, Yi Sha remains a steadfast advocator of traditional

\footnotetext{
18 Tao Naikan and Simon Patton. 'Introduction: There Is Style in the Blood'. Yi Sha. Starve the Poets!, trans. Simon Patton and Tao Naikan. Northumberland: Bloodaxe Books, 2008, pp. 11-12.
} 
Chinese values. ${ }^{19}$ Luo Zhenya, after studying Yi Sha's poems of the 1990s, points out that Yi Sha was always constructing his own poetics through the use of irony, parody, colloquial words and mixed styles, though he played the role of a 'deconstructor' on the surface. He maintains that Yi Sha was still 'on the road' to becoming a real master in the 1990s, running in his own way in the right direction but facing a lot of 'obstacles' in art, including too many petit themes and occasionally being too prosaic in his language. $^{20}$

In ‘Shige ye shi tiaozhan: Yi Sha shige jianlun’ 诗歌也是挑战一一伊沙诗歌简论 (Poetry as a challenge: on Yi Sha's poetry), Tang Xin, a poet and critic himself, argues that Yi Sha's poetry is a detailed record of Chinese society in the 1990s, with a comic spirit and playful language. ${ }^{21}$ In a later article, 'Tianhua luanzhui: Yi Sha jinzuo jiedu' 天花乱坠——伊沙近作读解 (Flowers cascading from the sky: Yi Sha's recent poems), he further points out that 'if in the last century Yi Sha was primarily a rebellious poet, a "destructor" ... then he was more like a "constructor" in the new century. $\mathrm{He}$ started and created a brand-new poetic ideal, spirit and style, and is joining in and becoming a new tradition. ${ }^{22}$ Tang Xin is also the author of a monograph, Shuohua de shige 说话的诗歌(The speaking poetry), in which he gives a detailed description of the development of Colloquial Poetry from Yu Jian to poets born in the 1970s, with Yi Sha occupying a prominent position. However, this book fails to construct a systematic

\footnotetext{
19 Chen Zhongyi 陈仲义. 'Yi Sha shige lun: “shaduba” bosa ji “huwenxing” huishou’ 伊沙诗歌论: “杀毒霸” 播撒及 “互文性” 回收 (On Yi Sha's poetry: its “viral' spread and 'intertextual' retrieve). Wenyi zhengming 文艺 争鸣 (Literature and art forum), No. 10, 2009, pp. 136-41.

${ }^{20}$ Luo Zhenya 罗振亚. “Hou xiandai” lushang de gujue tanxian: 1990 niandai Yi Sha shige lun” “后现代”路上的 孤绝探险—1990 年代伊沙诗歌论 (A lonely exploration on the ‘postmodern’ road: Yi Sha's poems in the 1990s). Guangdong shehui kexue 广东社会科学 (Guangdong social sciences), No. 4, 2013, pp. 164-72.

21 Tang Xin 唐欣. ‘Shige ye shi tiaozhan: Yi Sha shige jianlun' 诗歌也是挑战——伊沙诗歌简论 (Poetry as a challenge: on Yi Sha's poetry). Lanzhou daxue xuebao 兰州大学学报 (Journal of Lanzhou University), No. 6, 2006, pp. 15-20.

22 Tang Xin 唐欣. 'Tianhua luanzhui: Yi Sha jinzuo jiedu' 天花乱坠一一伊沙近作读解 (Flowers cascading from the sky: Yi Sha's recent poems). Hongyan 红岩 (Red cliff), No. 1, 2014, pp. 164.
} 
poetics for Colloquial Poetry and merely treats it as a tendency in contemporary poetry. Deng Gen's article 'Yipi culi, zhengliang de shazi: ye tan Yi Sha shige de richang yu kouyu' 一匹粗䊉、铮亮的砂子一一也谈伊沙诗歌的日常与口语 (A coarse, shiny sand: everyday and colloquial elements in Yi Sha's poetry) explores the two persistent characteristics in Yi Sha's poetry: the theme of everyday life and colloquialism in language. ${ }^{23}$

Among Yi Sha's individual poems, his three most famous short poems 'Esi shiren' 饿 死诗人 (Starve the poets), 'Che guo Huanghe’ 车过黄河 (Crossing the Yellow River), 'Jiejiebaba' 结结巴巴 (St-stammering, st-stuttering) and the long poem Tang 唐 (Tang) are the most cited and studied ones. Chen Zhongyi gives a close reading to 'Crossing the Yellow River' and praises it as a specimen of decontructive poetics in mainland China. ${ }^{24} \mathrm{He}$ also examines the intertextuality in Tang, analysing how it works and how it occasionally fails to work. ${ }^{25}$ Chen Shaoli analyses the text of 'Starve the Poets' and points out a series of antitheses in the poem. ${ }^{26}$ Other individual poems that draw academic attention include 'Linghun chuqiao' 灵魂出空 (The soul leaving the body), 'Wo zhongyu lijie le ni de jujue' 我终于理解了你的拒绝 (I eventually understood your refusal), and 'Zhangchangshi, ni de baomu' 张常氏, 你的保姆 (Ms

\footnotetext{
${ }^{23}$ Deng Gen 邓艮. 'Yipi culi, zhengliang de shazi: ye tan Yi Sha shige de richang yu kouyu'一匹粗粝、铮亮的 砂子——也谈伊沙诗歌的日常与口语 (A coarse, shiny sand: everyday and colloquial elements in Yi Sha's poetry). Shanhua 山花 (Mountain flowers), No. 16, 2012, pp. 101-03.

${ }^{24}$ Chen Zhongyi 陈仲义. “Siliang zenneng bo qianjin: du Yi Sha “Huanghe” 四两怎能拨千斤一一读伊沙 “黄 河” (How does four liang move a thousand jin: reading Yi Sha's 'Yellow River'). Mingzuo xinshang 名作欣赏 (Masterpieces review), No. 21, 2008, pp. 63-65.

${ }^{25}$ Chen Zhongyi 陈仲义. 'Gujin shixin, heyi huwen jiaohui? - ping Yi Sha Tang nengfou chengwei mingpian' 古 今诗心, 何以互文交汇? ——评伊沙《唐》能否成为名篇 (Poetry hearts ancient and modern, how do they realise intertextuality? - on whether Yi Sha's Tang can become a masterpiece). Mingzuo xinshang 名作欣赏 (Masterpieces review), No. 9, 2005, pp. 105-11.

${ }^{26}$ Chen Shaoli 陈韶利. 'Shi li shi wai de maodun duili: xidu Yi Sha mingzuo “Esi shiren” 诗里诗外的矛盾对立 ——细读伊沙名作《饿死诗人》 (Antitheses inside and outside poetry: reading Yi Sha's 'Starve the poets'). Mingzuo xinshang 名作欣赏 (Masterpieces review), No. 1, 2006, pp. 61-64.
} 
Zhangchang, your nurse).

Existing research regarding minjian and Yi Sha only touches upon one or two aspects of the topic, but a systematic study of the connotation of minjian in the context of contemporary Chinese poetry and Yi Sha as a representative of this poetic trend has yet to appear. For Yi Sha, most researchers only pay attention to his role as a rebellious deconstructor of the conventional poetics, but his role as the constructor of a new poetry, though noticed by a few critics, has never been systematically studied. This thesis therefore will critically study the following aspects of Yi Sha's creative trajectory - the links between Yi Sha and minjian, Yi Sha's poetics and his poetry activities, as well as Yi Sha and the foreign - to interpret such a controversial figure, who stands steadfast in the fast-changing climate of contemporary Chinese poetry scene.

\section{Methodology}

Existing research into Minjian Poetry has focused on the polemic debate, but assessment based on the polemic debate alone is limited in its ability to fully comprehend the scope and depth of minjian as poetic practice. In order to address both the polemic and aesthetic dimensions of minjian, and understand minjian as a practice, this thesis will adopt a multidisciplinary approach to the case study of Yi Sha and related topics. The thesis will take the shape of a critical biography, through which I shall conduct close reading of texts, theoretical discussion, discourse analysis and historical contextualisation.

Different methods are considered for their suitability to bring out the various dimensions of minjian as a full poetic practice. Textual analysis and close reading are used to study Yi Sha's poetry and poetics. I have obtained all the poetry collections and essays on poetry by Yi Sha up till 2015, 24 books in total, published with or without an ISBN. As an ISBN is quite expensive in China and poetry books generally do not sell, 
it is common practice for poets to print their own books without an ISBN. That sometimes happens even to established poets like Yi Sha. My research also involves three unpublished works by Yi Sha, which I obtained directly from the poet during my fieldwork in China. I therefore have the most comprehensive primary sources to study this significant contemporary Chinese poet.

The critical biography seems to have gone out of favour amongst literary scholars, and this partly explains why most of the monographs on contemporary Chinese poetry focus on poetry collectives or poetic themes, rather than on a single poet. For reasons I have stated above, this investigation into the literary phenomenon of minjian takes the form of a critical biography of a single author. The primary sources for my biographical research on Yi Sha include interviews, personal records, letters, diaries and essays, as well as other information related to Yi Sha's personal life and literary activities. Apart from print sources, the internet is also an important venue to collect research data. As Yi Sha is very active online, he leaves numerous records on his blog, Weibo, as well as many poetry forums and poetry websites, all of which have been quite useful to my research. A central part of my biographical research is an extensive interview I conducted with Yi Sha over the course of several months in 2016. Given the importance of this interview as a full account of Yi Sha's engagement with minjian poetry, I have included the full text of this interview in the Appendix.

Although originating from biographical research, my interview with Yi Sha focuses on the discursive issues of minjian and Colloquial Poetry, as well as the poet's own account of how his life experiences interact with the development of his literary and aesthetic outlook. Therefore, discourse analysis is employed to study Yi Sha's positions, intentions and purposes embedded in his comments. For instance, I am intrigued why Yi Sha, himself an intellectual and university professor, exalts Charles Bukowski as his American counterpart. Scholars in Cultural Studies have explored Charles Bukowski's life and poetics, focusing on his working-class stance, his presentations of an anti-hero rebel and outsider, as well as his writing of the cultural ordinary and everyday self- 
narrative, for example, Abel Debritto's Charles Bukowski, King of the Underground: From Obscurity to Literary Icon. I borrow some of the methods in Bukowski studies in my study of Yi Sha, although I approach Yi Sha primarily as an intellectual, or perhaps a minjian hero, but not a literary rebel like Bukowski.

Jürgen Habermas's public sphere has inspired Chen Sihe's earlier study of minjian in the broader context of modern Chinese literature. I find that an extended notion of public sphere is highly relevant to understanding the cultural habitat of Chinese minjian poets and their practice. In the case of Yi Sha, his cultural habitat is characterized by both physical and virtual realities (internet, poetry reading, teaching and publishing), and by frequent boundary crossing (provincial cities versus Beijing; China versus overseas; Chinese versus English, etc.). It is important to identify the cultural spheres or spaces that are available to a minjian poet, and how those spaces are inhabited and utilized to reinforce his unofficial stance and colloquial poetics.

Considering that minjian has a broad range of connotations that are context-specific and constantly evolving, I chose to use the pinyin term minjian throughout my thesis, instead of an English expression, because I have not found an appropriate rendering and do not wish to run the risk of being reductionistic or misleading. By refraining from translating the term, I am able to bring out its wide, embedded connotations. My intention is to construct this study as a translational exercise, one that aims at unpacking, contextualising, testing, and hopefully elucidating the term minjian as it manifests in contemporary Chinese poetry. Combining discourse analysis with a critical biography of the poet, I will demonstrate the complex relationship that minjian poetry has with China's cultural establishment, the literary avant-garde, and world literature. I will argue that Yi Sha's minjian is both a cultural stance and an aesthetic choice, with broad cultural and ideological repercussions. In other words, understanding the concept of minjian is imperative to the understanding of contemporary Chinese poetry. 


\section{Chapter Outline}

My thesis consists of four chapters. Chapter One focuses on the theoretical debate on minjian and provides a working definition of minjian not as a static theoretical concept, but as an ongoing poetic practice. The remaining three chapters form the core of my case study of Yi Sha, each focusing on one aspect of his minjian poetry practice, from the development of his colloquial poetics, to the manifestation of his unofficial stance, and finally to his engagement with translation and world poetry.

In Chapter One, 'Minjian in Polemics: From Panfeng to Yi Sha', I will construct a working definition of minjian, as the term is used in the context of contemporary Chinese poetry. This chapter discusses the emergence and development of the notion of minjian in contemporary Chinese poetry-its origins, connotations and implications. To achieve this goal, I will first introduce the Panfeng Polemic, a chaotic poetic debate in 1999, in which the word minjian become the name of a group of poets formerly known as the Colloquial Poets. My discussion will extend to the major connotations of the word minjian in Chinese context: folk literature, earthly aesthetics and the unofficial. By analysing Yu Jian's article in the Panfeng Polemic, I argue that the minjian notion in contemporary Chinese poetry has two elements: Colloquial Poetry and unofficial stance. Meanwhile, it is not a nativist or nationalist idea but a notion under the influence of international poetry. Though minjian as the name of a poetry group appeared in 1999, its characteristics first emerged in Chinese poetry in the 1980s. The Minjian poetry group that formed in the late twentieth century is a group of intellectuals under the title minjian. By this label they revealed their earthly poetics and unofficial stance. After the appearance of the minjian notion, it became an ideal with numerous followers on the Chinese poetry scene of the 2000s. To date, Yi Sha is the most representative Minjian Poet, who fully represents the minjian characteristics. This chapter seeks to answer

three questions: 1 . What is the nature of the Panfeng Polemic, the pivotal event that made minjian a buzzword for Chinese poetry in 1999? 2. How did the notion of minjian evolve in Chinese literary history and how was it re-articulated as a key concept in 
contemporary Chinese poetry? 3. What is Yi Sha's role in the making of minjian and how did he emerge as a minjian hero?

Chapter Two, 'Minjian in Poetics: Yi Sha's Colloquial Poetry', focuses on the aesthetic aspects of minjian by discussing the role of Colloquial Poetry in the formation of minjian poetics. The Colloquial Poets that emerged in the 1980s are often regarded as the forerunners of minjian, and Colloquial Poetry is sometimes used interchangeably with minjian poetry. However, the word 'colloquial' in the colloquial poetics of minjian poetry can be misleading. What is colloquial about Colloquial Poetry? Even within the minjian camp, poets have different understandings of colloquialism and think differently about what remains at the core of their poetics. Through close readings of Yi Sha's poetry as well as elaborations on Yi Sha's involvement with Colloquial Poetry, I explore three interrelated questions: On what grounds should Colloquial Poetry be understood as an anti-lyrical poetics beyond mere colloquialism? What are the distinctive features of Yi Sha's Colloquial Poetry? What is Yi Sha's contribution to the theorization of Colloquial Poetry?

Chapter Three, 'Minjian in the Digital Age: Yi Sha's Poetry Activities', focuses on Yi Sha's poetry-related activities and his deliberate choice of an unofficial stance in opposition to China's official literary establishment. In the context of contemporary Chinese poetry, the word 'official' can be understood in both aesthetic and institutional terms. To be institutionally official, in the Chinese context, denotes the close connection between a poet and one or more official institutions. However, being institutionally official does not equate with being aesthetically 'official'; the latter implies that a poet subscribes to a full set of state ideologies and writes within state guidelines through a process of internalised self-censorship. Yi Sha is arguably one of the very few established Chinese poets who manages to remain both institutionally and aesthetically unofficial. I will analyse three major activities that have shaped and defined Yi Sha's reputation as a minjian poet: his contribution to the poetry website Poetry Jianghu, his establishment of the Chang'an Poetry Festival and the ambitiously named digital 
anthology 'New Poetry Classics'. The primary purpose of the discussion is to demonstrate how Yi Sha navigates the intricate passages between official and unofficial cultural spaces in contemporary China, and how age-old jianghu ethos and new-found digital savvy have joined forces in the making of a representative Minjian Poet. More broadly, these activities reflect the cultural habitat and behaviour patterns of the minjian poets as a group, as they struggle to survive outside of the officially sanctioned cultural mainstream. As an exemplary figure of the minjian group, Yi Sha not only puts his minjian principles into practice but also proves that poetry can survive and prosper without the patronage of China's official institutions.

Chapter Four, 'Minjian in Global Context: Yi Sha and the World', demonstrates that the rise of minjian poetry is not an isolated Chinese phenomenon and must be examined in its broader global context. It is widely acknowledged that contemporary Chinese poetry has been greatly influenced by Western poetry through translation since the 1980s, and minjian poetry is no exception. Although one cannot completely circumvent the issues of influence, the critical assumptions of influence studies, as well as its attendant dichotomies of China/West and local/global, have been increasingly challenged by more fluid and inclusive critical perspectives from recent developments in the studies of world literature. In this chapter, while acknowledging obvious sources of influence, I will present the Minjian Poets not as passive recipients but as proactive agents who interact with the world of poetry beyond China, through translation and being translated, and through publishing overseas in both Chinese and foreign languages. Again, using Yi Sha as a revealing case study, I will explore Yi Sha's multifaceted engagement with Western poetry and how his translational and transnational poetry activities have reshaped the relationship between Chinese poetry and world literature. Taking departure from the 'anxiety of influence' debate, I will argue that Chinese minjian poetry has moved beyond the quagmire of influence and has embraced translatability as a means to communicate minjian poetics to the world. 


\section{Chapter One Minjian in Polemics: From Panfeng to Yi Sha}

The term，民间，(minjian-literally 'among the people') since its emergence in the context of contemporary Chinese poetry in the late 1990s, has become one of the most prevalent in discussions of Chinese poetry among poets, critics and scholars. It went 'viral' in the Chinese poetry circles in the first decade of the twenty-first century as poetic activities and debates shifted to online forums. However, while everyone talks about minjian, few people see eye to eye about the term. Like many other terms that prevail among Chinese poets and critics, the meanings and connotations of minjian need to be investigated and clarified. This chapter discusses the emergence and development of the concept of minjian in contemporary Chinese poetry-its origins, connotations and implications. I will focus on answering three questions: 1 . What is the nature of the Panfeng Polemic, the pivotal event that made minjian a buzzword for Chinese poetry in 1999 ? 2. How did the notion of minjian evolve in Chinese literary history and how was it re-articulated as a key concept in contemporary Chinese poetry? 3. What is Yi Sha's role in the making of minjian and how did he emerge as a minjian hero?

The word minjian itself is not new. It has been in the Chinese language for a long time. It first appeared in Mozi 墨子 (Mozi): 'Zhi youming zhe yi ji yu minjian zhe zhong 执有命者以集于民间者众' (It is due to the large number of fatalists among the people). ${ }^{27}$ Literally speaking, the two-character word minjian consists of min 民 (people, folk) and jian 间 (between, among), so its basic meaning is 'among the people'. Considering China's long history of authoritarian state control and its tradition of state control over cultural production, this word also implies the meaning of being 'unofficial', if not 'subversive'. Moreover, if we take into account the Chinese classification of minjian wenxue 民间文学 (folk literature), the word minjian here

${ }^{27}$ Mozi 墨子. Mozi 墨子 (Mozi), trans. W. P. Mei, https://ctext.org/mozi/anti-fatalism-i, accessed 3 December 2019. 
means 'folk', as minjian wenxue refers to literary works produced orally, and/or anonymously by the common people, or 'folk', as differentiated from works of literature created by the educated elite or the intellectuals. These basic meanings'among the people', 'popular' and 'unofficial'-all contribute to our present understanding of Minjian Poetry. However, minjian, as a keyword that surfaced during the Panfeng lunzheng 盘峰论争 (Panfeng Polemic) in 1999, took on more specific connotations that were directly associated with the divergence and rivalry between two major groups of Chinese poets. One group was called the Zhishifenzi 知识分子 (Intellectual) Poets, while the other group was then nameless, but roughly known as the Kouyu 口语 (Colloquial) Poets, and later became known as the Minjian Poets. ${ }^{28}$

\section{Intellectual Poets vs. Colloquial Poets}

The difference between Intellectual and Colloquial Poetry can be traced back to the poetry movements in the 1980s. After menglongshi 朦胧诗 (Obscure poetry) ${ }^{29}$ made its debut in the late 1970 s, Chinese poetry soon entered into a time called the postObscure Period 后朦胧时期, with the appearance of a new generation of poets known as the Third Generation 第三代 or the New Generation 新生代. ${ }^{30}$ Compared with Obscure Poets, they focused more on personal life than on national or social issues. As summarized by poet and critic Zhou Lunyou 周伦佑, himself the leading poet of feifei zhuyi 非非主义 (Not-Not or Non-ism) the Third Generation was characterized by

\footnotetext{
28 At the Panfeng Polemic, the Intellectual Poets included Wang Jiaxin 王家新, Xi Chuan 西川, Zang Di 㶓棣, Sun Wenbo 孙文波, Xi Du 西渡, Ouyang Jianghe 欧阳江河 and Chen Dongdong 陈东东, while among the Colloquial Poets were Yu Jian 于坚, Han Dong 韩东, Yi Sha 伊沙, Xu Jiang 徐江, Yang Ke 杨克, Shen Haobo 沈浩波 and many others.

${ }^{29}$ Menglong shi 朦胧诗 is sometimes translated as the Misty Poetry. However, Bonnie McDougall and Kam Louie think that translation is 'misleading' and adopt 'obscure' in their The Literature of China in the Twentieth Century, for menglong originally means 'difficult to understand'. See Bonnie S. McDougall and Kam Louie. The Literature of China in the Twentieth Century. Gosford: Bushbooks, 1998, p. 426.

${ }^{30}$ Generally the first generation refers to socialist realist poets like Gong Liu 公刘, Guo Xiaochuan 郭小川 and He Jingzhi 贺敬之. The second generation refers to Obscure poets like Bei Dao 北岛 and Shu Ting 舒婷.
} 
'anti-sublimity', 'anti-culture', 'anti-rhetoric' and 'anti-imagery'. ${ }^{31}$ However, the Third Generation was not a single group but a general name for various avant-garde poetry groups in the 1980s. Each group had their own aesthetic stances and experimented individually on writing. Some of the influential groups were Feifei 非非 (Not-Not), Manghan 莽汉 (Macho men), Tamen 他们 (Them) and Haishang 海上 (At sea). Colloquial Poetry emerged from among these groups. For instance, the Them group was composed purely of the Colloquial Poets, and the Macho Men group also bore the distinct characteristics of Colloquial Poetry. Some poets in other groups, such as Yang Li 杨黎 of the Not-Not group, may also be identified as Colloquial Poets.

In the spring of 1985, the first issue of Them was published, which was considered as a landmark for the Third Generation. The editor-in-chief was listed as Fu $\mathrm{Li}$ 付立, a pseudonym for the editors Yu Jian and Han Dong, two forerunners of Colloquial Poetry. Them soon became the gathering venue of the poets writing in the style of Colloquial Poetry. Yu Jian and Han Dong were invited to the 1986 Youth Poetry Meeting 青春诗 会, a programme hosted by Shikan 诗刊 (Poetry periodical), the most renowned official poetry journal in China, for the purpose of nurturing young talents. This event signified that Colloquial Poetry was officially being admitted by the mainstream of Chinese poetry establishment.

A year later, at the 1987 Youth Poetry Meeting, Xi Chuan, Chen Dongdong and Ouyang Jianghe appeared on the list of attendees. It was in this meeting that they came up with the idea of 'Intellectual writing' (zhishifenzi xiezuo 知识分子写作), in an attempt to correct the vernacularizing trend in Chinese poetry and to advocate refined language and imagery. In 1989, they published the first issue of Qingxiang 倾向 (Tendency), which then became a gathering venue of the Intellectual Poets. Although the Intellectual Poets made their collective debut in the Chinese poetry scene after, and in response to,

\footnotetext{
31 Zhou Lunyou 周伦佑. 'Disandai shilun 第三代诗论' (On the poetry of the Third Generation). Conference article at National Poetic Theory Symposium in Yangzhou, 1988. http://www.yuanliuw.com/html/201301/40461.html, accessed 30 June 2016.
} 
the Colloquial Poets, many of the individuals in this group were already established poets. In most of the 1990s, the Intellectual Poets experienced a steady rise in fame and influence, and almost became the representatives of contemporary Chinese poetry. In comparison, the Colloquial Poets, as a group, became somewhat less vocal and active. Yet both groups remained at the forefront of China's poetic avant-garde, and constituted the two most dynamic poetic forces in China throughout the 1990s.

The tension between the two rival groups reached its apex and exploded in the Panfeng Polemic. Their divergence was not only literary but also political and cultural. In terms of their positions on poetics, broadly speaking, the Intellectual Poets believed in the importance of the Western modernist canon and pursued sophisticated expressions in poetry, whereas the Colloquial Poets strived to develop China's own native modernism by embracing a colloquial poetics. However, as I will demonstrate in my discussion of Yi Sha's interactions with world literature in Chapter Four, the Colloquial Poets also sought inspiration and nourishment from Western literature. In terms of their broader cultural stance, the Colloquial Poets stood for the 'unofficial' - hence their readiness to embrace and claim the moniker of minjian. But the Colloquial Poets had no exclusive claim on the unofficial stance, for the Intellectual Poets also claimed to be independent of the mainstream, state-sanctioned communist ideology, and were therefore 'unofficial', as well. Thus, as the Panfeng Conference went on, divergence turned to rivalry, and debate into debacle. What made the Polemic a messy situation was that the discussions quickly fell outside of rational poetic debate and degenerated to accusations, name-calling and even personal attacks. One of the most significant, and also the most benign, instances of name-calling was the renaming of the Colloquial Poets as the 'Minjian Poets'.

\section{The Panfeng Polemic: The Naming of Minjian}

It is important to understand the Panfeng Polemic not as a singular event, but as an 
ongoing literary debate that consisted of three stages. I call these three stages 'before the conference', 'at the conference', and 'after the conference'.

\section{Before the Conference}

The fuse of the polemic was the publication of two poetry anthologies. On the Intellectual side, in 1998, the Beijing-based critic, Cheng Guangwei 程光伟, published Suiyue de yizhao: jiushi niandai wenxue shuxi, shige juan 岁月的遗照: 九十年代文 学书系, 诗歌卷 (A portrait of years gone by: literature of the nineties, poetry volume). This anthology excluded all of the Colloquial Poets except Yu Jian and Han Dong. As a reaction, Shen Haobo, then an undergraduate at Beijing Normal University, wrote a fierce article: ‘Shui zai na jiushi niandai kaishuan’ 谁在拿九十年代开涮? (Who was making a fool of the nineties?). Shen's article, first published in the BNU's Wusi wenxue bao 五四文学报 (May Fourth literary news) under the pseudonym of Chou Shui 仇 水 and later reprinted in many venues, launched the initial attack on Cheng and the Intellectual camp. On the Colloquial side, in early 1999, Yang Ke brought out 1998 Zhongguo xinshi nianjian 1998 中国新诗年鉴 (1998 yearbook of China’s new poetry) as a response to Cheng Guangwei's anthology. Yang Ke's anthology mainly selected poets on the Colloquial side, though it also included a few Intellectual poets. The most impressive feature was the motto printed on the cover of the 1998 Yearbook: 'In art, we take the real, eternal minjian standpoint' 在艺术上我们秉承: 真正的永恒的民间立 场. This was the first time the word minjian appeared in the context of contemporary Chinese poetry.

\section{At the Conference}

From 16 to 18 April 1999, a conference titled 'Turn of the Century: A Symposium on the Creation Tendency and Theoretical Construction of Chinese Poetry'世纪之交：中 国诗歌创作态势与理论建设研讨会 was held at the Panfeng Hotel 盘峰宾馆, 
Pinggu County, Beijing, (later referred to as the Panfeng Conference 盘峰会议). The conference, under the auspices of Beijing wenxue monthly 北京文学 (Beijing literature), Shi tansuo 诗探索 (Poetry explorations), the Beijing branch of the Writers' Association, and the Contemporary Chamber of the Research Institute for Literature, Chinese Academy of Social Sciences, gathered over 40 poets and critics and had a long list of topics on Chinese poetry. When the discussion moved to Intellectual and Minjian writing, a hotly-contested debate ensued, each side launching fierce polemics against the other. The attendees split into two camps, as many of them had already debated poetics and the Chinese poetry scene in the 1990s. However, like many other debates between Chinese poets, their arguments often went awry and slipped into personal attacks. ${ }^{32}$ A small incident occurred, which was not noticeable at the time but later proved to be one of the most important in the history of contemporary Chinese poetry. This was the naming of the Minjian group. According to Yi Sha, Wu Sijing 吴思敬, a professor from Capital Normal University and the host of the conference, when introducing both sides, casually said, since they 'take the real, eternal minjian standpoint, then let's call them the Minjian Poets'. ${ }^{33}$ Thus, the two sides of the debate became the Intellectual and the Minjian Poets.

\section{After the Conference}

After the verbal, face-to-face arguments of the two camps, the Panfeng Conference

\footnotetext{
${ }^{32}$ For a detailed account of the Panfeng Conference, see Zhang Qinghua 张清华. 'Yici zhenzheng de shige duihua yu jiaofeng- “shiji zhi jiao: zhongguo shige chuangzuo taishi yu lilun jianshe yantaohui” shuyao”一次真正的诗 歌对话与交锋——世纪之交：中国诗歌创作态势与理论建设”述要 (A real poetic dialogue and battle: an account of 'Turn of the century: a symposium on the creation tendency and theoretical construction of Chinese poetry'). Shi tansuo 诗探索 (Poetry explorations), No. 2, 1999, pp. 68-77. Yi Sha also has an essay on the conference but his account, full of rhetorical strategies, is biased against the Intellectual Poets, see Yi Sha 伊沙. 'Shiji mo: Shiren weihe yao dazhang' 世纪末: 诗人为何要打仗 (End of the century: why the poets are going to war). In Yi Sha 伊沙. Zhongguo xiandai shilun 中国现代诗论 (On modern Chinese poetry). Taipei: Showwe Information, 2011, pp. 247-60.

33 Yi Sha, Interviewed by Liang Yujing, 2016, see Appendix.
} 
finished on 18 April, but the real polemics seemed to have just begun, as these went on to appear in newspapers, magazines and on the Internet. Of course, it was public knowledge that the differences between the two camps, now in print, had originated well before the conference, in 1998 and 1999, and included Cheng Guangwei's and Yang Ke's anthologies and Shen Haobo's article attacking Cheng and the Intellectuals. Other major contributors to the polemics included Yu Jian, Han Dong, Xu Jiang, Yi Sha, Xie Youshun 谢有顺, Tang Xiaodu 唐晓渡, Wang Jiaxin, Xi Du 西渡 and Xi Chuan. In his monograph, van Crevel has put together a list of the polemics-related essays, articles and reports published between February 1998 and January 2002, which has 120 items in total. ${ }^{34}$ Before the conference, the articles were mostly written by poets and critics from the two camps. After the conference, one distinctive change was the participation of the third parties such as people using social media and critics outside the two camps, thus pushing this event outside the poetry circles and into the public sphere. Most of these articles, full of personal attacks, innuendos, distortions and namecalling, are generally illogical and non-poetic. According to van Crevel, the Polemic generally 'lost its real momentum' early in 2000, and what appeared afterwards were merely reverberations. ${ }^{35}$

\section{The Panfeng Polemic in Critical Assessment}

The Panfeng Polemic is arguably one of the most complex and controversial events in the history of contemporary Chinese poetry, and its after-effects lasted for over a decade. However, in the eyes of many critics, the Polemic is largely a chaotic and turbulent event that reflects the conflict of powers on the Chinese poetry scene with limited literary value, and an symptom of wenren xiangqing 文人相轻 (Men of letters despise each other). Critics, such as Dian Li and Michelle Yeh, hold such an opinion when

\footnotetext{
${ }^{34}$ Maghiel van Crevel. Chinese Poetry in Times of Mind, Mayhem and Money. Leiden: Brill, 2008, pp. 451-58. The list is part of a full chapter on the Panfeng Polemic in van Crevel's book, giving a comprehensive and detailed analysis of the polemic articles by some representative poets and critics of both sides.

35 Ibid, p. 449.
} 
talking about the Panfeng Polemic. Dian Li's article 'Naming and Antinaming: Poetic Debate in Contemporary China' examines the artistic positions of each of the sides through a reading of their respective chief spokespersons, such as Xi Chuan, Ouyang Jianghe, Wang Jiaxin, Xie Youshun 谢有顺, Han Dong and Yu Jian. By comparing the theoretical construction of both labels, Li discovers that the Intellectual and Minjian poetical content displays considerable overlap, for they both use qualitative vocabularies like 'marginalization', ‘independence', 'nonconformity' and 'personalization'. Thus the differences between the two schools are 'the choices of signifiers and not the definition of the signified'. ${ }^{36}$ By closely examining the theorization of minjian by the Minjian Poets like Xie Youshun and Yu Jian, Li finds that many terms the Minjian Poets use, such as yuyan ziyuan 语言资源 (language resources), are all problematic, and that their accusations of the Intellectual Poets are due to their misunderstanding of the latter's position. Li's analysis and comments reflect that the construction of minjian as a critical instrument is far from perfect. After recounting a brief history of poetic debates in the 1980s and 1990s, Li calls the Panfeng Polemic 'a continuation of the now familiar culture of debate and [that it] was also a realignment of Chinese poets' desire for naming and association', ${ }^{37}$ due to misunderstanding and misreading of each other's positions. Thus, it was 'a valiant collective effort by Chinese poets and critics to reconfigure the meaning of poetry in China's cultural discourse on tradition and modernity in the age of commercialism and globalization'.38

Michelle Yeh, in her article 'Anxiety \& Liberation: Notes on the Recent Chinese Poetry Scene', uses the Panfeng Polemic as an example to illustrate the 'Chineseness complex' on the contemporary Chinese poetry scene. According to Yeh, throughout the Polemic, the Intellectual Poets were portrayed by the Minjian camp as elitists, with this elitism being inseparable from their 'blind worship' of Western poetry. In contrast, the self-

\footnotetext{
36 Dian Li. 'Naming and Antinaming: Poetic Debate in Contemporary China'. In Christopher Lupke, ed., New Perspectives on Contemporary Chinese Poetry. NY: Palgrave Macmillan, 2007, p. 190.

37 Ibid, p. 199.

${ }^{38} \mathrm{Ibid}$, p. 200.
} 
image of the Minjian Poets was that of 'the underrecognized, disadvantaged poet' who kept writing about common life experiences with the 'plain, living language'. Yeh argues that, while the Polemic 'fed the media's hunger for sensationalism and maverick behaviour', it scandalized the poetry scene as a whole and 'probably did more damage than good to poetry'. 39

Both Dian Li and Michelle Yeh provide an insightful understanding of the nature of the Polemic as largely being not a serious poetic debate but a public performance. As a poetic debate, the Panfeng Polemic had no clear winners. In general, the Intellectual Poets, the more established side at the time, were on the defensive, while the Colloquial Poets took the offensive and challenged the Intellectuals. As a public performance, however, the Colloquial Poets seemed to have outshone the Intellectual Poets. Not only did they lay claim to the word minjian at the conference, and thereby transform themselves into Minjian Poets, they also made sure that minjian become the prevailing term on the Chinese poetry scene of the 2000s.

Neither Li's nor Yeh's article touches upon poetry itself or the difference between the poetry of the two camps. Power politics aside, poetry was, after all, what the poets were deeply concerned with. In my view, the nature of the debate, in spite of all the white noise, was actually about the clash of two kinds of poetics. Though the process of the Polemic was imbued with personal politics, the divergence of their poetics was at the heart of discord.

Critical assessment of the Panfeng Polemic to date has been focused on what transpired 'at the conference', with references to the gradual build-up towards the Polemic 'before the conference'. However, to put the Polemic in its proper perspective and understand its true significance, I maintain that a wider critical lens is necessary and more attention must be directed to what happened 'after the conference'. By 'after the conference', I

\footnotetext{
${ }_{39}$ Michelle Yeh. 'Anxiety \& Liberation: Notes on the Recent Chinese Poetry Scene'. World Literature Today, Vol. 81, No. 4, Inside China, July-August, 2007, p. 34.
} 
do not simply mean the numerous polemical articles the poets and critics wrote in the one or two years after the conference, but the subsequent developments in contemporary Chinese poetry in the decade that followed. If we take into account the subsequent poetry movements in the twenty-first century, such as Xiabanshen 下半身 (the Lower Body poetry), Laji pai 垃圾派 (Trash poetry ), Di shige 低诗歌 (Low poetry) and numerous other poetry groups in the 2000s, which all appeared under the banner of 'minjian', we begin to realise the magnitude of the minjian phenomenon and the importance of the Panfeng Polemic which catapulted the word into to the centre of contemporary Chinese poetic discourse. In this sense, the Panfeng Polemic was a watershed in the recent history of Chinese poetry, and minjian, both as the name of a poetry group and as a poetic concept, has had a tremendous impact on the Chinese poetry scene in the twenty-first century.

Perhaps Maghiel van Crevel is one of the few critics who recognises the full import of the Panfeng Polemic. In Chinese Poetry in Times of Mind, Mayhem and Money, he devotes an entire chapter to the Panfeng Polemic, providing a comprehensive analysis of the event. In the chapter entitled 'What Was All the Fuss About?: The PopularIntellectual Polemic', he examines every notable published article on both sides in great detail and his final analysis shows the full complexity of this issue. In van Crevel's opinion, though dividing lines from geographical-cultural, institutional and biographical angles can expose a skeleton inside the dynamics of the Panfeng Polemic, the Polemic is about nothing less than the legacy of Chinese poethood, namely, 'the right to see oneself and one's comrades-in-arms as torchbearers in a long-standing tradition'. ${ }^{40}$ He suggests that 'perhaps an alternative to calling the Polemic meaningful or meaningless is to view it as a natural phenomenon-like a tidal wave, or a thunderstorm'. ${ }^{41}$

Van Crevel's discussion of the Panfeng Polemic is also implicitly linked to his broader

\footnotetext{
${ }^{40}$ Maghiel van Crevel. Chinese Poetry in Times of Mind, Mayhem and Money. Leiden: Brill, 2008, p. 447. 41 p. 450 .
} 
study of contemporary Chinese poetics in the earlier chapters of his book. He divides Chinese avant-garde poetry since the 1980s into the schools of the Elevated and the Earthly, suggesting that: "[Chinese] avant-garde poetry can be viewed as a spectrum between the outer limits of two divergent, broadly defined aesthetics' ${ }^{42}$ He gives a set of dichotomies to describe the characteristics of the two sides. Whereas the Elevated are usually associated with expressions connotating 'heroic', 'literary', 'cultural', 'mythical', 'sacred', 'utopian', 'absolute', 'elitist', 'academic', 'Westernized', 'central', 'Northern', 'mind' and 'intellectual', the Earthly cherishes the values of being 'quotidian', 'colloquial', 'anti, pre- or non-cultural', 'anti-lyrical', 'anti-mythical', 'mundane', 'realist', 'relative', 'ordinary', 'authentic', 'indigenous', 'local', 'Southern', 'body' and 'popular'. ${ }^{43}$ Moreover, he explains that 'the Elevated and the Earthly are not pigeonholes but coordinates in a multidimensional body of texts', as every poet lies between the two extremities but has a tendency toward one side or the other. ${ }^{44}$ Van Crevel's analysis of the Elevated and the Earthly offers a useful working basis for the discussion of contemporary Chinese poetics, and points to the aesthetic and poetic issues that were at stake during the Panfeng Polemic and in the debates that ensued.

Although the Polemic itself was chaotic and generally non-poetic, it did highlight some basic differences in poetics similar to those between the Elevated and the Earthly. To some extent, the contentious and illogical discussions of minjian during the Polemictreating it as 'colloquial', 'earthly', 'folk', 'unofficial', 'non-governmental', 'native' or 'local'- helped to enrich the connotations of the term and made it an easy banner for the various new poetry groups to hold. Van Crevel does not make an explicit link between 'the Earthly' and 'minjian' in his book, yet the two terms do share many similar connotations. Like the Earthly, which occupies one end of a spectrum, minjian is also an elastic term with porous and negotiable borders. In spatial terms, it is an open and contestable site. As I will demonstrate through the case study of Yi Sha, the flourishing

\footnotetext{
42 Ibid, p. 24.

43 Ibid, p. 25

44 Ibid, p. 26.
} 
of numerous poetry groups and poetry activities online, in what might be called a 'democratisation of poetry' in digital China in the twenty-first century, on Weibo, Wechat and other online platforms, is in large part indebted to the Panfeng Polemic and the legitimation of minjian.

\section{Two Key Connotations of Minjian: Colloquial Poetics and Unofficial Stance}

The transformation of Colloquial Poetry into minjian poetry at the Panfeng Conference might have seemed somewhat accidental, as a result of Wu Sijing's off-hand renaming of one of the rival groups. However, what might have seemed merely a name change turned out to be of great significance to the evolution of the term minjian. The Colloquial Poets immediately embraced this new name and made it a prevailing term in their discussions through a series of essays. By adopting this new name, the Colloquial Poets became associated with one of the most complicated terms in Chinese poetic discourse. Through association with the Colloquial Poets, the word minjian also took on a new set of connotations. As I will discuss in the following section, two connotations - a colloquial aesthetic orientation and an unofficial cultural stancebecame prominent in the discourse around minjian in contemporary Chinese poetry. I will demonstrate that both connotations have long existed in different iterations of minjian throughout Chinese literary and cultural history; however, it was in the poetic discourse after the Panfeng Polemic when the two connotations became combined and intertwined for the first time in the shaping of a new poetics and its associated group of poets.

\section{Iterations of Minjian in Chinese Literary History}

When we consider minjian in the context of literature, the term minjian wenxue 民间 文学 immediately comes to mind, a term that is often considered equivalent to 'folk literature' in English. In the European tradition, folk literature indeed has strong 
associations with the oral and the colloquial. According to Encyclopaedia Britannica, folk literature, also called folklore or oral tradition, is 'the lore of cultures having no written language'. It is 'transmitted by word of mouth and consists, as does written literature, of both prose and verse narratives, poems and songs, myths, dramas, rituals, proverbs, riddles, and the like. Nearly all known peoples, now or in the past, have produced it' ${ }^{45}$ This definition highlights the orality of the production and transmission of folk literature.

In the Chinese tradition, however, the oral characteristics of early literature have long been entangled with the written medium, a prerogative of the cultural and political elite. In classical Chinese poetry, Shijing 诗经 (Classic of poetry) $)^{46}$, Yuefu Poetry ${ }^{47}$, Shang ge 山歌 (Mountain songs) and Guazhi'er 挂枝儿 (The dangling branch) ${ }^{48}$ are all considered to have their roots in folk literature and the oral tradition. However, much of this folk tradition had been quickly appropriated by the literati and turned into primarily written genres and forms. Yuefu, a literati genre written in the style of folk poetry that first flourished during the Six Dynasties period, is a case in point. ${ }^{49}$ In its

\footnotetext{
45 'Folk literature' entry. Encyclopaedia Britannica. https://www.britannica.com/art/folk-literature, accessed 4 July 2016.

46 It is highly possible that Shijing 诗经 (Classic of poetry) includes a large body of archaic folk songs. The poems in Classic of poetry, traditionally being dated between 1000 and $600 \mathrm{BCE}$, are mostly authorless and, in terms of content, can be divided into two parts: 'Airs of the States' 国风; the hymns 雅 and eulogies 颂. 'Airs of the States' are 'mostly shorter lyrics composed in simple formulaic language that frequently seem to assume the voice of the common folk.' See Martin Kern, 'Early Chinese Literature, beginnings through Western Han'. In Kang-I Sun Chang and Stephen Owen, eds. The Cambridge History of Chinese Literature, Cambridge: Cambridge University Press, 2010, vol. 1, p. 20.

47 Yuefu Poetry is a relatively broad and loose concept which includes a miscellany of poems, some of which, especially the early ones, are generally believed to be of folk provenance, while other poems are considered literati imitations. Hans Frankel proposed a definition that contains seven points, of which the first three are related to the Music Bureau of the Han, and the third one reads: 'it meant anonymous songs collected by the Music Bureau from various parts of China (the Chu region was the richest source) and from abroad. Most of these already had tunes; for those that did not, music was composed at the Bureau.' See Hans Frankel. 'Yüeh-fu Poetry'. Studies in Chinese Literary Genres. Ed. Cyril Birch. Berkeley, CA: University of California Press, 1977, p. 69.

48 Shang ge 山歌 (Mountain songs) and Guazhi'er 挂枝儿 (The dangling branch), compiled by Feng Menglong 冯梦龙 (1574-1646), are very likely to include some genuine folk songs. Mountain songs was uncovered in 1934 by Zhu Ruixuan 朱瑞轩, proprietor of Chuanjing Tang 传经堂 bookstore in Shanghai, and caused a stir among the New Culture Movement intellectuals like Hu Shi 胡适 who "saw the find as invaluable in their advocacy for a "genuine literature" that originated in the experience of the people (minjian 民间)'. See Wu Cuncun. “"It Was I Who Lured the Boy": Commoner Women, Intimacy and the Sensual Body in the Song Collections of Feng Menglong (1574-1646)'. Nan Nü 12 (2010), p. 313.

49 Yuefu poetry became popular among literati during Jian'an and Wei with its notable authors like Cao Cao 曹操,
} 
centuries-old history, Yuefu poetry demonstrates how a poetic genre that came from the folk tradition can influence literati writing over a long period of time and eventually become completely absorbed by literati writing. By the Tang Dynasty, there was no longer folk Yuefu poems and literati Yuefu became dominant in this genre. Although scholars are in disagreement about the authenticity of its folk origin, Tang Dynasty Yuefu nonetheless retained some distinctive qualities of folk literature, such as the use of vernacular, colloquial and plain expressions to depict daily life. Often these 'folk elements' are evoked and deployed as a refreshing antidote against the artificial and staid qualities of literary conventions. As Luo Genze notes, as the pompous style of Southern Dynasties gradually came to be detested by the Tang people, the Tang Dynasty Yuefu poems took on an aesthetics of simplicity, which was closer to the original Yuefu poetry. ${ }^{50}$ From the early Tang to the high Tang a great number of notable poets were associated with this genre. Li Bai 李白 is considered a master of this genre, whose Yuefu poems outnumbered any other high Tang poets with approximately 120 Yuefu titles. ${ }^{51}$ The mid-Tang witnessed a revival of the early Tang discourse of the 'ancient' with different representations among literati. For poets like Yuan Zhen 元稹 and Bai Juyi 白居易, it means the 'new Yuefu', which was 'the use of poetry to speak out on moral and political issues'.52 After the Tang, Yuefu as a poetic genre gave way to new genres such as $c i$, a type of lyric poetry inspired by music and singing, which performed a similar cultural function in the revitalisation and transformation of Song Dynasty poetry.

Although folk literature has long existed in China in heavily appropriated and

\footnotetext{
Cao Pi 曹丕, Cao Zhi 曹植 and Cao Rui 曹睿. In the Jin and Southern Dynasties, this prosperity continued to last and a number of literati wrote in the style of Yuefu poetry, such as Lu Ji 陆机, Xie Lingyun 谢灵运, Bao Zhao 鲍照, Wang Rong 王融, Xie Tiao 谢眺, Emperor Wu 梁武帝, Jianwen 简文帝 and Yuan 元帝 of Liang, Shen Yue 沈约, Chen Houzhu 陈后主 and Jiang Zong 江總.

${ }^{50}$ Luo Genze 罗根泽. Yuefu wenxue shi 乐府文学史 (A history of yuefu poetry). Beijing: Wenhua xueshe, 1932, p. 203-04

51 Joseph R. Allen. In the Voice of Others: Chinese Music Bureau Poetry. Ann Arbor: Centre for Chinese Studies, The University of Michigan, 1992, p. 168.

52 Stephen Owen. 'The Cultural Tang'. Kang-I Sun Chang and Stephen Owen, eds. The Cambridge History of Chinese Literature, Vol. 1. Cambridge: Cambridge University Press, 2010, p. 334.
} 
intervened forms, the term minjian wenxue 民间文学 as a literary and critical concept did not appear until the May Fourth Movement in early $20^{\text {th }}$ century. ${ }^{53}$ The earliest definition came from Hu Yuzhi 胡愈之, who argued in his article 'Lun minjian wenxue' 论民间文学 (One folk literature), published in Funü zazhi 妇女杂志 (Women’s magazine) in 1921, that 'the meaning of minjian wenxue is roughly the same as "folklore" in English and "Volkskunde" in German, referring to the literature popular in the nation'. He also explained the two characteristics of minjian wenxue: first, it is created by 'the nation as a whole instead of individuals'; second, it is Oral Literature 口述的文学 instead of Book Literature 书本的文学. ${ }^{54}$ The May Fourth interest in minjian wenxue, which was defined similarly as 'folk literature' in English, shows clear Western influences; yet the application of the term also reflects the broader political motivations and ideological currents at the time. In 1927, Xu Weinan's 徐蔚南 Minjian wenxue 民间文学 (Folk literature), the first monograph on this topic, gave a similar definition by emphasizing its collective creation and orality while adding that it belongs to 'proletarians' 无产阶级, comes from the 'common folk' 民间, and is 'revised by numerous persons and loved by the great majority of people'. 55 This understanding became dominant for a long time after the founding of the People's Republic of China. Contemporary Chinese scholars have turned their focus away from its association with class structure and generally accept minjian wenxue as literary works with four characteristics: collectivity, orality, heredity and variability. ${ }^{56}$ However, the political overtones of minjian wenxue persisted, and continued to be

\footnotetext{
53 According to Li Xiaoling's 李小玲 research, the Chinese term minjian wenxue 民间文学 first appeared in the correspondence between Mei Guangdi 梅光迪 and Hu Shi 胡适 on 19 March 1916. In early twentieth century, it was interchangeable with other terms like baihua wenxue 白话文学, guoyu wenxue 国语文学 and pingmin wenxue 平民文学. See Li Xiaoling 李小玲. 'Fan ben su yuan: dui zhongguo minjian wenxue gainian ji lilun de fansi’ 反本溯源：对中国民间文学概念及理论的反思 (Tracing the source: reflections on the concept and theory of Chinese folk literature). Tansuo yu zhengming 探索与争鸣 (Exploration and free views), No. 10, 2017, p. 156.

${ }^{54} \mathrm{Hu}$ Yuzhi published the article under the name of Yuzhi. See Yuzhi 愈之. 'Lun minjian wenxue' 论民间文学 (On folk literature). Funü zazhi 妇女杂志 (Women’s magazine), Vol. 7, No. 1, 1921, p. 32.

$55 \mathrm{Xu}$ Weinan 徐蔚南. Minjian wenxue 民间文学 (Folk literature). Shanghai: Shijie shuju, 1927, p. 6.

${ }^{56}$ Chen Yongchao 陈泳超. “Zuowei xueshu shi duixiang de “minjian wenxue”, 作为学术史对象的“民间文学” (Minjian wenxue as a subject of academic research). Minzu wenxue yanjiu 民族文学研究 (Studies of ethnic literature), No. 1, 2004, p. 10.
} 
echoed in other popular usages of the word minjian.

In everyday language, minjian is often used to mean 'unofficial', 'non-governmental' or 'people-to-people'. Minjian may refer to any persons, anything outside the Chinese official system. There are phrases like minjian jigou 民间机构 (non-governmental organizations), minjian xuezhe 民间学者 (independent scholars), minjian jiaoliu 民 间交流 (non-governmental exchanges) and minjian ziben 民间资本 (private capital). As China is a country with a long history of authoritarian state control, the dichotomy of guan 官 (the official) and min 民 (the people) is much more deeply entrenched than in many other countries. Since Emperor Qin Shi Huang 秦始皇 adopted a whole system of bureaucracy to establish the power of the central government, this institution had been continuously reinforced by the governments of every period until the end of the Qing Dynasty in 1912. After the founding of the People's Republic of China, though the government claimed itself to be the representative of the people, the tradition of bureaucratic hierarchies and divisions has not only continued but also has been strengthened. Under the camouflage of public ownership and communism, the government's power controlled nearly all the areas, leaving little room for the unofficial activities. The Party-state thrives with its authoritarian power and monopoly. The guan/min dichotomy prevails in every aspect of society, especially in cultural production. In many cultural arenas, the stamp of official approval is generally considered a guarantor of quality, reliability, not to mention legitimacy. Government sponsored universities, academic journals, and literary awards are considered of better quality and of greater value. On the other hand, anything associated with min or minjian, being inherently unofficial, is viewed with suspicion and considered somewhat inferior. Such words like 民间学者 (independent scholars) and 民间医生 (unaffiliated doctors) still imply that they are not authoritative or professional, and therefore of lower quality. The official/unofficial dichotomy became less clear-cut in the post-Mao era, as China went through political reform and economic privatisation, yet the biased mentality still persists. 
The official/unofficial dichotomy is met with the strongest resistance in the area of literature and art, where institutional affiliation is not necessarily a mark of quality. There are indeed writers who can be considered 'official', because, since the Chinese Writers' Association 中国作协 is an official organization, its members can be therefore called 'official writers' and in the past many of them could get salaries from the association. However, few of these writers would like their work to be considered 'official literature'. Van Crevel has noted the ambiguity in the use of the word 'official' among Chinese poets - they often desire to be institutionally official while they are ashamed of being aesthetically official. ${ }^{57}$ Thus, the 'unofficial poet' is not an inferior title. On the contrary, it reveals a hint of avant-garde and heroism, for it shows the poet's defiance of the official communist ideology. Poetry magazines can be also seen in this way: the government-run Shikan 诗刊 (Poetry Periodical) is the most prestigious publication almost every poet wants to appear in, but when discussing the contemporary poetry scene, people often give more attention to the unofficial magazines like Jintian 今天 (Today), Them, Not-Not and Tendency.

The two key connotations of minjian - colloquial poetics and unofficial stance, are not stable qualities but contested sites in Chinese literary history. The oral or colloquial aspects of minjian literature have always been entangled with the written medium and literati taste. The unofficial status of minjian writers, although suggesting a lack of official recognition and its attendant benefits, can project an aura of independent heroism and aesthetic risk-taking that is prized by official and unofficial writers alike. And it is the articulations and claims around these two connotations that fuelled much of the Panfeng Polemic and much of the poetic debate in the ensuing decade.

\section{Contesting Minjian in Contemporary Chinese Poetry}

The previous discussion highlights the two key connotations underlying the word

57 Maghiel van Crevel. Chinese Poetry in Times of Mind, Mayhem and Money. Leiden: Brill, 2008, p. 10. 
minjian - colloquial poetics and unofficial stance-by tracing its usage in Chinese literary history. However, both these connotations were hotly contested, and their meaning and relationship transformed, during the Panfeng Polemic. To understand how the meaning of minjian shifted after the Polemic, it is useful to ask the following questions: When the Colloquial Poets became relabelled as Minjian Poets, how did the renaming destabilise the power dynamics amongst the rivalling groups in contemporary Chinese poetry? Why was the Minjian Poets' exclusive claim on being 'unofficial' problematic to the rest of contemporary Chinese poets? And what did minjian mean to the Minjian Poets? And what responsibilities came with the prerogative of being called a Minjian Poet?

In the early 1990s, years before the Panfeng Polemic, the Chinese critic Chen Sihe 陈 思和 drew attention both at home and abroad with his study of minjian, and brought this word into focus among the academia years before it was highlighted in the poetry circles. In two seminal articles 'Minjian de fuchen' 民间的浮沉 (The ups and downs of minjian) and 'Minjian de huanyuan'民间的还原 (The restoration of minjian), Chen employs minjian as a strategy to rewrite modern Chinese literary history, offering an overview of Chinese literature from the 1930s to the present day. Chen points out that there have been three dynamic forces - the state ideology, the intellectual and minjian - interacting with each other in modern Chinese literary history. ${ }^{58}$ The minjian Chen refers to is the folk as a cultural space that lies on the margins of the state power, as a force resistant to the official, similar to but still different from Jürgen Habermas's 'public sphere'. Dian Li points out that as a critical instrument, Chen's construction of minjian is flawed by 'its ahistorical applications and its signifying instability'. ${ }^{59} \mathrm{Li}$ further notes that the connection between Chen's and the Minjian Poets' concepts of minjian 'remains tenuous at best' ${ }^{60}$ However, Chen Sihe's study sheds light on the

\footnotetext{
58 Chen Sihe 陈思和, 'Minjian de fuchen 民间的浮沉 (The ups and downs of minjian)'. Shanghai wenxue 上海 文学 (Shanghai literature), no. 1, 1994, p. 70.

59 Dian Li. 'Naming and Antinaming: Poetic Debate in Contemporary China'. In Christopher Lupke, ed., New Perspectives on Contemporary Chinese Poetry. NY: Palgrave Macmillan, 2007, p. 188-89.

${ }^{60}$ Ibid, p. 189.
} 
confusion about the understanding of the word minjian and can serve as a point of departure to reconsider the identity of the Minjian Poets.

Obviously, the minjian that appeared in 1999 in contemporary poetry can be hardly put into the category of folk literature, as their poetry was neither orally created nor collectively transmitted, and the poems were created by and circulated among the educated elite. Moreover, nearly all the major Minjian Poets are university graduates. Yu Jian graduated from Yunnan University, Han Dong from Shandong University, while Yi Sha, Xu Jiang and Shen Haobo all graduated from Beijing Normal University. In this sense, they are all intellectuals who fluctuate between the folk and the state ideology, resistant to both sides. ${ }^{61}$ Are the Minjian Poets unofficial? Not institutionally. At the time of the Panfeng Polemic, Yu Jian, the leading figure of the group, was an editor of a magazine under the Yunnan Federation of Literature and Art 云南省文联, and Yang Ke, who edited the 1998 Yearbook, worked as an editor for Zuopin 作品 (Literary works), a journal affiliated with Guangdong Writers' Association 广东省作协. Yi Sha also worked for Xi'an International Studies University 西安外国语大学. They were and still are all within the institution and thus should be considered official. However, they are aesthetically unofficial, which means their works do not keep accord with, but rather, pose challenges to the state ideology. In terms of the traditional connotations of the word minjian, 'the folk' and 'unofficial' do not completely apply to the Minjian Poets, which makes it more difficult to understand the connection between the group and its branding.

Not only did the Minjian poets' claim on their unofficial status seem problematic, their critical writing suggests that they had more ambitious goals in mind as they redefined and claimed the term minjian. Take, for example, Yu Jian's influential essay 'Dangdai shige de minjian chuantong 当代诗歌的民间传统, (The minjian tradition of contemporary poetry), written in 2001 in the aftermath of the Panfeng Polemic. The

${ }^{61}$ Chen Sihe 陈思和, 'Minjian de fuchen 民间的浮沉 (The ups and downs of minjian)'. Shanghai wenxue 上海 文学 (Shanghai literature), no. 1, 1994, p. 70. 
word minjian in this essay shifts to and fro, from 'the folk', 'unofficial', 'earthly aesthetics' to sometimes 'native'. When talking about the revival of poetry and fiction after the Cultural Revolution (1966-1976), Yu Jian wrote:

In the 1970 s, poetry and fiction were both considered subversive to the system, but poetry began with minjian, while the 'return' of fiction started with official publications. Minjian became the tradition of contemporary Chinese poetry; all the outstanding poets made their debut in minjian publications, became influential and established before they were accepted by the official magazines.

在七十年代, 诗歌和小说都是异端, 但诗歌的出发点是民间, 小说的“归来” 却是从正式的出版物。民间成为中国当代诗歌的传统, 杰出的诗人无不首先 出现在民间刊物，影响形成后，才被公开刊物所接受。62

In this statement, it is easy to understand minjian as 'unofficial', since what Yu Jian refers to are the unofficial publications, especially the independent, if not underground, literary magazines. Most of them did not even have an ISSN, like Today, which marked the revival of contemporary poetry after the Cultural Revolution. However, he soon makes broader claims about minjian by reaching back to the early roots of Chinese poetry:

Minjian is not a stance of resistance; minjian is the basic presence of poetry. Minjian is not alternative word for 'underground', which stands in opposition to official institution. Minjian is opposed to nothing but the very being of poetry, with its existence going back to antiquity. Where did Classic of poetry appear?

民间不是一种反抗姿态，民间其实是诗歌自古以来的基本在场。民间并不

\footnotetext{
${ }^{62}$ Yu Jian 于坚. 'Dangdai shige de minjian chuantong' 当代诗歌的民间传统 (The minjian tradition of contemporary poetry). Dangdai zuojia pinglun 当代作家评论 (Review of contemporary writers), Issue 4, 2001, p. 84.
} 
是 “地下” 的另一个说法。地下相对的是体制。民间不相对于什么, 它就是 诗歌基本的在场。这一在场从古代就已经存在着。《诗经》是在哪里出现的?

63

There is a shift in the meaning of minjian; here Yu Jian denies minjian as mere underground (unofficial), while skilfully expanding its connotation to a long-existing historical cultural space where folk literature (Classic of poetry) takes place. The two meanings overlap to some degree, but they basically belong to different literary categories. What Yu Jian did was disguise himself and his group as part of the folk tradition to seek theoretical support. When talking about the Intellectual-Minjian polemic, he maintains:

The fundamental difference between the so-called 'Minjian writing' and the socalled 'Intellectual writing' is that, the latter often stands for 'another shore' ideology $[\ldots]$ while minjian always attaches itself to the world of life, only the quotidian experience and common sense, only the things you rely on for living, homeland, earth, life and presence.

所谓的 “民间写作” 与所谓的 “知识分子写作”之间的根本分歧, 是因为后 者常常要标榜某种彼岸式的意识形态……而民间依附的永远只是生活世界, 只是经验、常识, 只是那种你必须相依为命的东西, 故乡、大地、生命、在 场、人生。64

Through these remarks, Yu Jian reveals a certain truth of the Polemic. The two sides are both intellectuals standing away from the state ideology and the official. However, their aesthetics become divergent when the Intellectual poets embrace the 'other shore' ideology and values, namely the Western, the faraway, the elsewhere, in a word, the Elevated. The Minjian Poets stand for the here and now, the native, the homeland, the

\footnotetext{
63 Ibid, p. 87.

${ }^{64}$ Ibid, p. 88
} 
Chinese, the Earthly. In this essay, Yu Jian uses minjian as a catch-all phrase that, reasonably or unreasonably, refers to every basic relevant connotation of this word, as long as it is useful, to help strengthen his argument.

It is perfectly justifiable that the Minjian Poets would define themselves and their poetry with the two most salient connotations of minjian in the literary context-colloquial poetics and unofficial stance. However, their tendency to lay exclusive claim on these two qualities, particularly on the latter (unofficial stance), was problematic and bound to be challenged by other poetic groups. Both colloquial poetics and unofficial stance had strong associations with the emergence of Obscure Poetry in the late 1970s and remained prominent features of contemporary Chinese poetry in general throughout the 1970s, 1980s and 1990s.

Obscure Poetry was arguably the earliest embodiment of the unofficial stance in contemporary Chinese poetry and signalled the reawakening of the minjian spirit immediately after the Cultural Revolution. The factors leading to the emergence of Obscure Poetry can be traced back to the underground poetry 地下诗歌 during the Cultural Revolution and even earlier. According to Bonnie S. McDougall and Kam Louie, 'The main characteristic of the 1970s and 1980s (still ignored in orthodox Chinese accounts of the period) is the intensification of the gap between official and non-official writing that had its beginnings in the 1940s, 1950s and 1960s.' ${ }^{65}$ This gap gradually developed to a point that 'the existence of a literary underground in modern China is a phenomenon of the 1970s and 1980s'. ${ }^{66}$ Notable underground poetry groups in the 1960s included X shishe X 诗社 (X Poetry Society) and Taiyang zongdui 太阳 纵队 (The Sun's Column). ${ }^{67}$ The Sun's Column had great influence over the most

\footnotetext{
${ }^{65}$ Bonnie S. McDougall and Kam Louie. The Literature of China in the Twentieth Century. Gosford: Bushbooks, 1998, p. 421.

66 Ibid, p. 423.

${ }^{67}$ X Poetry Society was founded by Guo Shiying 郭世英 (1942-1968) at Peking University in February 1963 but was deemed subversive in May in the same year by the authorities. Guo Shiying's father was the poet Guo Moruo 郭沫若 (1892-1978), who is a major forerunner of modern Chinese poetry. Guo Shiying was sentenced to reeducation through labour and committed suicide after being tortured by Red Guards in 1968. The Sun's Column,
} 
prominent underground poet Guo Lusheng 郭路生 (penname Shi Zhi 食指), noted for his famous pieces 'Xiangxin weilai' 相信未来 (Believing in the future) and 'Zhe shi si dian ling ba fen de Beijing' 这是四点零八分的北京 (This is Beijing at 4:08). ${ }^{68}$

The distinction between 'underground Literature' 地下文学 and 'people-run publications' 民办刊物 is important in understanding the two forms of unofficial poetry. Bonnie S. McDougall points out that 'underground literature refers to privately circulated literature that is hidden or at least withheld from the authorities', whereas popular [people-run] publications were 'openly circulated, often in printed form though not through official channels' ${ }^{69}$ In an article on the underground poetry, Maghiel van Crevel uses 'underground literature' to denote texts written after the founding of the People's Republic in 1949, while he admits that 'for many texts circulated after the 1978 thaw, people-run is more appropriate than underground'. ${ }^{70}$ Furthermore, he maintains that 'the common denominator for underground literature and people-run publications is unofficial 非官方'. ${ }^{71}$ Van Crevel's viewpoint is largely valid, but what needs to be added is that underground literature was not a unique phenomenon before the 1978 thaw but an ongoing one throughout the entire history of the PRC, even in the 1980s, the 1990s and the recent decades into twenty-first century. The range and production of 'unofficial literature' varies according to the political atmosphere of the day. When the political atmosphere is severe, more literature goes underground. Once the political atmosphere relaxes, more literature comes out to the surface. One example

created by Zhang Langlang 张郎郎 after a poetry recital at the Central Institute for Industrial Art 中央工艺美术 学院 in 1962, ended up with Zhang's imprisonment in 1968.

${ }^{68}$ According to Lijia Zhang, Guo Lusheng was closely associated with the members of The Sun's Column but he has never been admitted into its formal membership. Thus, he escaped being condemned as a 'counterrevolutionary' when the group was labelled a 'counterrevolutionary' organization in 1966. See Lijia Zhang. 'Mad Dog: The Legend of Chinese Poet Guo Lusheng'. Mānoa, Vol. 14, No. 1, 2002, p. 106. A collection of Guo Lusheng's (Shi Zhi) poetry has been translated into English, see Shi Zhi. Winter Sun, trans. Jonathan Stalling. Norman, OK: The University of Oklahoma Press, 2012.

${ }^{69}$ Bonnie S. McDougall. 'Dissent Literature: Official and Nonofficial Literature In and About China in the Seventies'. Contemporary China, III, No. 4, 1979, p. 57 \& p. 64.

${ }^{70}$ Maghiel van Crevel. 'Underground Poetry in the 1960s and 1970s'. Modern Chinese Literature, Vol. 9, No. 2 (Fall 1996), p. 170.

${ }^{71}$ Ibid, p. 171. 
is, in the years following the Tiananmen Massacre in 1989, almost all the avant-garde poetry went underground immediately. It was still being written but was hardly publishable even in people-run publications. It went above ground again after Deng Xiaoping's Southern Tour Speech in 1992. In short, both underground literature and people-run publications have been part of the Chinese unofficial literary scene and both are key elements that led to the rise of minjian.

The founding of the Today magazine, the representative of China's unofficial poetry publications, was a significant event. The late 1970s witnessed the appearance of an important underground group Baiyangdian shiqun 白洋淀诗群 (Baiyangdian poetry group). Its major members included Mang Ke 芒克, Duo Duo 多多, Gen Zi 根子 and Lin Mang 林莽. Many of them became the later Today Poets. In 1978, Bei Dao 北 岛, Mang Ke and others created the people-run journal Today and distributed it on and around the Democracy Wall 民主墙 in Beijing, which signified that the Today Poets went from underground to above ground, though still unofficial. It ran for nine issues and published four books before state censorship stopped it in 1980. Its authors included Bei Dao, Duo Duo, Shu Ting 舒婷, Jiang He 江河, Yang Lian 杨炼 and many others. Every one of them would in time produce poems to transform the contemporary Chinese poetic scene and become a poet well-respected by readers and critics in and outside of China.

However, back in August 1980, a hostile article entitled 'Lingrenqimen de "menglong"” 令人气闷的 “朦胧” (Annoying 'obscurity') was published in Poetry Periodical by Zhang Ming 章明, criticising their poetry as being 'obscure' 朦胧, which led to a wide-ranging discussion and finally gave the name, Obscure Poetry, to the poems. In the initial years of the 1980s, the Today Poets came under attack from Party officials and became a major target of the Anti-Spiritual Pollution Campaign 清除精神污染运 动 in 1983. Nevertheless, as an unofficial poetry group, Obscure Poets became extremely influential in the 1980s and gained an international audience through English translators like Bonnie S. McDougall, David Hinton, Mabel Lee and Brian Holton. In 
1990, Bei Dao revived Today in Norway and later moved to Sweden. Since 2011, Today has collaborated with American publisher Zephyr Press on publishing a series of contemporary Chinese poets in English translation.

After the Obscure Poets rose to fame and established themselves as the unofficial voice in Chinese poetry by the mid-1980s, they put much pressure on the unofficial poets who came after them. These younger poets, often called The Third Generation, tried to find a new path both in style and theme. Michael Day summarises the differences of Obscure Poetry and the Third Generation poetry as follows: humanism vs the primal state of the life of the individual; lofty feelings vs a weightless feeling; responsibility vs selfcentred individualism; a revolt against alienation vs the acceptance of alienation. ${ }^{72}$ Unlike Obscure Poetry that arose from ruins of the Cultural Revolution, the Third Generation poetry is closer to modernism in temperament, the product of a freer world with the individual feeling more alienated and fragmented.

Meanwhile, unlike Obscure Poets who were mostly residents of Beijing when they wrote for Today, most of these new poets came from the provinces, and their coming into being signified that the centre of poetry had moved from the national capital to the provincial centres. This geographic change is significant, as is reflected in Michael Day’s study of China's 'Second World of Poetry' 第二诗界, a term coined by Not-Notist Zhou Lunyou, with Sichuan of the 1980s as its centre. In Day's words, the term refers to 'a sub-field in the general field of contemporary Chinese poetry, inhabited by poets more responsive to, and more influenced by, each other and translated works than to officially published poetry and criticism'. ${ }^{73}$ In other words, the Second World of Poetry is the unofficial world of poetry where the avant-garde poets were more inclined to form their own circles both aesthetically and institutionally to resist the official establishment. They not only tried to build a connection between each other but also

\footnotetext{
72 This is my brief, key-word summary of Day's statements. For a detailed description, see Michael Day, China 's Second World of Poetry: The Sichuan Avant-garde, 1982-1992. Leiden: Digital Archive for Chinese Studies (DACHS). Leiden University, 2005, pp. 25-26.

73 Ibid, p. 10.
} 
between themselves and the poetry from other countries in foreign languages through translation.

Under such circumstances, some of the so-called Third Generation Poets began to consciously produce and promote a poetry with earthly aesthetics that embraces a more succinct way of expression, which was later known as Colloquial Poetry. Colloquial Poetry, focusing on everyday life, was a revolt against the Obscure Poetry's obsession with the grand themes such as history and the nation. ${ }^{74}$ The Shanghai-based poet Wang Xiaolong 王小龙, 'the first Colloquial Poet' according to Yi Sha ${ }^{75}$, was the among the first to challenge the aesthetics of Obscure Poetry. In 1982, when defining a poet as an ordinary person who starts to write poetry by accident, Wang implicitly criticised the Obscure Poets and their followers. ${ }^{76}$ In Yi Sha's eyes, Wang's 'Jinian' 纪念 (Commemoration), a poem written in 1982 speaking to his deceased father, was the first real Colloquial poem in contemporary China. In 'Commemoration', Wang tells of the difficult daily life of a man but in a tongue-in-cheek way, showing a trend different from the grand theme and serious tone of Obscure Poetry.

According to Tang Xin 唐欣, the frequent use of the term Kouyu shi 口语诗 (Colloquial Poetry) appeared in the discussions organised by publications like Shige bao 诗歌报 (Poetry news) in the mid-1980s, primarily referring to 'poetry written in colloquialism' or 'with the characteristics of the spoken language. ${ }^{77}$ It was associated with poetry groups like Them, Not-Not, Macho Men, the Lower Body, with Yu Jian,

\footnotetext{
${ }^{74}$ Xi Du 西渡. 'Dangdai shige de richanghua yundong—cong Wang Xiaolong, Han Dong dao Luo Yihe' 当代诗 歌的日常化运动——王小龙、韩东到骆一禾 (The Movement of returning to everyday life: from Wang Xiaolong, Han Dong to Luo Yihe). Jiefangju yishu xueyuan xuebao 解放军艺术学院学报 (Journal of PLA Academy of Art), No. 1, 2016, p. 152.

75 Yi Sha, Interviewed by Liang Yujing, 2016, see Appendix.

${ }^{76}$ Xi Du 西渡. 'Dangdai shige de richanghua yundong—cong Wang Xiaolong, Han Dong dao Luo Yihe' 当代诗 歌的日常化运动——王小龙、韩东到骆一禾 (The Movement of returning to everyday life: from Wang Xiaolong, Han Dong to Luo Yihe). Jiefangju yishu xueyuan xuebao 解放军艺术学院学报 (Journal of PLA Academy of Art), No. 1, 2016, p. 152.

77 Tang Xin 唐欣. Shuohua de shige 说话的诗歌 (The speaking poetry). Beijing: Zhongguo shehui kexue chubanshe, 2012, p. 1.
} 
Han Dong, Yang Li, Li Yawei 李亚伟, Yi Sha and Shen Haobo as its representatives. As its name indicates, the most apparent characteristic of this poetry is colloquialism, the everyday, spoken language. In a later period, the name 'colloquial' is not just the style of language but develops into a whole set of earthly aesthetics in poetry with its emphasis on the immediate, direct representation of the material in plain language. In the 1980s, Han Dong's famous remark 'Shi dao yuyan weizhi’ 诗到语言为止 (Poetry ends in language) was an extremist expression of this poetics, that is, only the language matters and there are no other implications beyond the language, a poetics of anticulture that attempts to get rid of the cultural and historical burden in poetry. By the time of the Panfeng Polemic in 1999, Colloquial Poetry had become a noticeable force on the Chinese poetry scene.

Unofficial poetry groups continued to boom in the 1980s. In 1986, 'Major Exhibition of Modernist Poems in China' 现代诗群体大展, initiated by Xu Jingya 徐敬亚, sponsored by Poetry news and Shenzhen qingnian bao 深圳青年报 (Shenzhen youth daily) was a comprehensive display of the Third Generation poets. The exhibition included nearly 70 poetry societies with their poetics and works. Most of them were included in an anthology in 1988, Zhongguo xiandaizhuyi shiqun daguan 中国现代主 义诗群大观 (An overview of China’s modernist poetry groups). Of these poetry groups, quite a few were obviously colloquial or earthly in their aesthetics, closer to Wang Xiaolong rather than to Obscure Poetry in style. In the anthology, Obscure Poetry takes the primary place as the most influential group; the one next to Obscure Poetry is Not-not-ism 非非主义, a Sichuan-based unofficial poetry group with some Colloquial Poets, such as Yang Li. In the third place appears Them 他们, a group of typical Colloquial Poets, including Yu Jian and Han Dong, who later became the leading figures of the Minjian poets in the Panfeng Polemic in 1999. In the fifth place is Macho Men 䒭汉主义, another Colloquial poetry group with its representative Li Yawei, known for his poem 'Zhongwen xi' 中文系 (The Chinese department). Therefore, a glimpse at this anthology tells us that Colloquial Poetry had become an influential force on the Chinese poetry scene by 1988 . 
At the Youth Poetry Meeting in 1987, Xi Chuan, Chen Dongdong and Ouyang Jianghe came up with the concept of 'Intellectual Writing' 知识分子写作, to characterize their group's poetry writing. They considered themselves as 'unofficial' but wanted to differentiate themselves from Colloquial Writing. The Intellectuals centred around a separate range of magazines, the best known of which include Fandui 反对 (Against), Qingxiang 倾向 (Tendency) and Jiushi Niandai 九十年代 (The nineties). The Intellectuals were the most prominent poetry group in the 1990s in China. ${ }^{78}$

The evolution of the various avant-garde groups in contemporary Chinese poetry suggests that the Colloquial Poets, as the precursors of Minjian Poets, and the Intellectual Poets were in fact different cuts from the same cloth-they both belonged to the 'Third Generation' of the Chinese poetic avant-garde, and both inherited the independent spirit, or unofficial stance, of the Obscure Poets, while at the same time rebelling against the overpowering influence of Obscure Poetry by seeking different trajectories and articulations in poetics. Therefore, critics such as van Crevel have argued that the Intellectual-Minjian dichotomy during the Panfeng Polemic, to a large extent, is a false one, as they are not completely contradictory to each other. Both sides are resistant to the state ideology and their difference only lies in their aesthetics: The Elevated versus The Earthly, and they are 'not pigeonholes but coordinates in a multidimensional body of texts. ${ }^{79}$ The two sides are merely the two ends of an aesthetic spectrum.

I tend to agree with van Crevel's assessment, on the aesthetic front-a typical minjian poet is also an intellectual, keeping a certain distance from state ideology, writing poetry

\footnotetext{
${ }^{78}$ Cheng Guangwei 程光炜 studies the connotations of 'Intellectual writing' and divides it into three types: 1. 'Intellectual writing' influenced by contemporary political culture; 2. 'Intellectual writing' in the sense of western culture; 3. 'Intellectual writing' in the sense of traditional Chinese culture. See Cheng Guangwei 程光伟. 'Jiushi niandai shige: ling yi yiyi de mingming’ 九十年代诗歌: 另一意义的命名 (Poetry in the nineties: naming in another sense). Shanhua 山花 (Mountain flowers), No. 3, 1997, p. 70.

79 Maghiel van Crevel. Chinese Poetry in Times of Mind, Mayhem and Money. Leiden: Brill, 2008, p. 26.
} 
with colloquial, earthly aesthetics. However, I think there is still scope to rise further above the Intellectual/Minjian dichotomy. What new patterns might emerge if we view minjian as an independently developing notion over the entire span of contemporary Chinese poetry rather than as the opposition of the Intellectual Poets during one instance of Chinese poetic debate in 1999. Then we might come to understand the value of $\mathrm{Yu}$ Jian's radical expansion of the notion of minjian to encompass everything truthful and worthwhile about poetry-indeed, the very essence of Chinese poetry since antiquity. If we follow this line of thinking and embrace the dimensions of minjian as both an aesthetic ideal and a cultural stance, or a cultural stance through a particular way of aesthetic expression, then we might begin to see that Obscure Poetry, Colloquial Poetry and Intellectual Poetry are all but different iterations of minjian. Their cultural stances are similar, as they all lean towards the unofficial, but their aesthetics are different.

Yi Sha has expressed a similar idea in one of his reflective articles on the Panfeng Polemic, in which he makes an explicit comparison between Colloquial Poetry and Obscure Poetry. Yi Sha points out that, similar to the Obscure Poetry Polemic which led to the widespread influence of Obscure Poetry, the Panfeng Polemic also 'arrives at the entire truth of Chinese poetry in the 1990s', that is, the existence of Colloquial Poetry, or minjian poetry. ${ }^{80}$ He further argues that the Panfeng Polemic was a catalyst for the development of Chinese poetry at the turn of the century much like the Obscure Poetry Polemic 朦胧诗论争 in the early 1980s. Echoing Yu Jian's elevation of minjian to a quintessential poetic quality that permeates throughout the history of Chinese poetry, Yi Sha maintains that minjian is not a cult or organisation, nor a narrowminded school in art but a moral-spiritual space that all Chinese poets must dwell in. He characterises this moral-spiritual space as being 'unofficial in standpoint, localised in existence, avant-garde in artistic expression 作为基本立场的民间性，存在形式的

\footnotetext{
${ }^{80}$ Yi Sha 伊沙. 'Zuowei shijian de “Penfeng lunzheng”: zai Hengshan Shihui “Jiushi niandai hanyu shi yanjiu luntan” shang de fayan’ 作为事件的 “盘峰论争” ——在衡山诗会 “九十年代汉语诗研究论坛” 上的发言 ('Panfeng Polemic' as an incident: a speech on the 'Forum for studies of Chinese poetry in the nineties' at Hengshan Poetry Conference). In Yi Sha 伊沙. Zhongguo Xiandai Shilun 中国现代诗论 (On modern Chinese poetry). Taipei: Showwe Information, 2011, p. 279.
} 
本土化和作为艺术追求的先锋性, ${ }^{81}$

In both Yu Jian and Yi Sha's estimation, minjian is a contestable term that any influential poetry group in contemporary China may lay claim to. It only so happened that the Colloquial Poets were accidentally 'named' with the term. It may seem like an easy victory, a free gift, for the Colloquial Poets, but now as Minjian poets, they are also burdened with the task of defining the term minjian and living up to the expectations determined by all its various connotations. The Minjian poets could not take their name for granted; nor could they claim to be minjian through polemics alone; they have to prove themselves through their writing and activities and withstand the test of time.

\section{Yi Sha: The Making of a Minjian Hero}

Yi Sha was not the leader of the Minjian camp at the time of the Panfeng Polemic. During the 1999 Polemic, the major poets on the Minjian side included Yu Jian, Han Dong, Yang Ke, Yi Sha and Shen Haobo. Yu Jian and Han Dong were then considered the leading poets on the Minjian side, who contributed the most influential essays on the notion of minjian, including Yu Jian's 'The Minjian Tradition of Contemporary Poetry’ and Han Dong’s ‘Lun minjian’ 论民间 (On minjian). By contrast, Yi Sha did not contribute any substantial theoretical work to support the notion of minjian. After the conference, from 1999 to 2000, Yi Sha published at least ten articles, of varying length, about this incident, including reports about what happened in the conference, refutations of the Intellectual poets, and his opinion about the Panfeng Polemic. In general, Yi Sha was not a theorist. Unlike Yu Jian and Han Dong, who attempted to theorize the notion of minjian through their articles, Yi Sha was more inclined to use his biting pen to attack his 'enemies'. Therefore, Yi Sha's articles related to the Panfeng

${ }^{81}$ Ibid, p. 282. 
Polemic were not of much theoretical value. In these articles, he was more a performer than a thinker; it was an opportunity for him to show his stance and standpoint. Though he was still a follower of Yu Jian and Han Dong at this stage, his identification with the minjian notion, with Colloquial Poetry and the 'unofficial' stance, was clearly expressed in these seemingly paltry articles. ${ }^{82}$

As the Intellectual/Minjian debate subsided after the Polemic, Yi Sha emerged as the most charismatic poet who carried on the minjian banner and embodied the spirit of minjian both in words and action. Though Yu Jian, Han Dong and Shen Haobo all demonstrate some aspects of minjian writing at some stage of their careers, the most persistent and self-consciously minjian poet is Yi Sha, whose entire career to date has been an exercise in minjian poetics and polemics.

Yi Sha's writing career started when he was in the middle school in Xi' an. He describes this period as 'I was born with an institutional face' 我有一张体制的脸, ${ }^{83}$ which indicates that he was then a boy with an institutional literary dream, eager to follow the path of an official writer and go through the door of the Writers' Association. His middle

\footnotetext{
${ }^{82}$ The longest one of these articles, 'Shiji mo: shiren weihe yao dazhang' 世纪末: 诗人为何要打仗 (End of the century: why the poets are going to war), was published in Wenyou 文友 (Friends in letters) in 1999 and simultaneously published in Shi Cankao 诗参考 (Poetry reference) as 'Liangge wenti he yige beijing: wo suo jingli de Panfeng shihui' 两个问题和一个背景: 我所经历的盘峰诗会 (Two questions against one background: the Panfeng Conference as I experienced it). Though described by van Crevel as 'a shamelessly biased report' (van Crevel 2008, 430), this article is the only detailed account of the Panfeng Conference from the Minjian side. His other articles related to the polemic included 'Liangben nianjian de beihou'两本年鉴的背后 (Behind the two yearbooks, 1999), 'Jiujing shui feng le?’ 究竟谁疯了 (Who indeed is crazy?, 1999), 'Sanduan lun'三段论 (Syllogism, 1999), ‘Beijing de wenxue mingong’ 北京的文学民工 (Migrant literary labourers in Beijing, 1999), 'Leitai bian shang de zhanshu' 擂台边上的战书 (A letter of challenge by the ring, 2000), 'Zhongchang ping shi' 中场评诗 (Commenting on poetry at half-time, 2000), 'Shenme shi yin, shenme shi an?' 什么是阴, 什么是暗? (What is evil and what is dark?, 2000) and “"Renhua” zhongyu tuchu' “人话”终于吐出 ('Reasonable words' finally spoken, 2000). These articles were generally short, written for attacking the other side or in response to the attacks from the other side. Though they were eloquent and sharp, they did not have much theoretical value for minjian. The last of this series of articles, "Zuowei shijian de “Panfeng lunzheng”, 作为事件的“盘峰论争” (“Panfeng Polemic" as an incident), originally delivered as a speech at Hengshan Poetry Conference 衡山诗会 in August, 2000, was a more comprehensive reflection on the Polemic, in which Yi Sha, no longer entangled in personal animosities, commented on the incident from the perspective of poetry.

83 Yi Sha. 'Yi Sha lun' 伊沙论 (On Yi Sha). In Yi Sha 伊沙. Zhongguoxiandai shilun 中国现代诗论 (On modern Chinese poetry). Taipei: Showwe Information, 2011, p. 68.
} 
school poems were lyrical and romantic, very different from his anti-lyrical style in his later days. As a teenager, he published poetry and received awards, which also helped him to get admitted to Beijing Normal University. At his earliest stage, Yi Sha appeared to be a literary youth, who had nothing to do with the minjian elements.

Change happened in his university days, when he began to read literature with a taste different from the mainstream, official one. At university, his classmates included $\mathrm{Xu}$ Jiang and Hou Ma 侯马. All of them later became his fellow poets on the Minjian side. According to Yi Sha himself, his early influences include Shu Ting 舒婷, Fu Tianlin 傅天琳, Gu Cheng 顾城, Bei Dao 北岛, Yu Jian, Han Dong, Li Yawei, Yang Li, Ding Dang 丁当, Wang Yin 王寅, Wang Xiaolong 王小龙, Ke Ping 柯平 and Yan Li 严 力. ${ }^{84}$ The names on this list moves from Obscure Poets 朦胧诗人 to almost all the major Colloquial poets of the 1980s, which definitely reflects a change in Yi Sha's own writing. As Yi Sha himself admits, 'I think it is Han Dong who established the earliest set of rules for Colloquial Poetry [...], which made me begin to write in the oral language overnight in June 1988.' 我以为是韩东建树了口语诗最早的一套规则 [...], 这套规则使我在 1988 年 6 月一夜之间进入了口语化的写作. In the last year of his study at Beijing Normal University, Yi Sha accepted the aesthetics of Colloquial Poetry and wrote some of his signature short poems, including 'Crossing the Yellow River'.

In June 1989, the month Yi Sha graduated from the university, he witnessed the outbreak of the Tiananmen protests and the subsequent massacre. There is no evidence that Yi Sha took part in the student movement and he returned to Xi'an to work after graduation. However, the increasingly oppressive political environment and stringent censorship in the aftermath of the Tiananmen Massacre greatly increased the difficulty of publishing literary works at home for many poets. Yi Sha, like many of his fellow Colloquial poets, was directly subjected to the intensity of the political suppression.

\footnotetext{
${ }^{84}$ Ibid. 73-78.
} 
Because their poems tended to be often more explicit and straightforward, closely related to the everyday life and social reality, they were the easy targets of censorship. Impossible to publish anything at home, Yi Sha began to submit his poems to the Chinese literary magazines overseas, including the New York-based Yihang 一行 (A line), the Melbourne-based Otherland 原乡, and many Taiwan-based magazines. His unpublishable state in China lasted until the political situation improved in 1992. During the four years from 1989 to 1992, Hai Zi 海子 and Wang Guozhen 汪国真 became China's most popular poets - Hai Zi for his artistic achievement and Wang Guozhen for his commercial success, whereas most Colloquial poets like Yi Sha remained silenced, for anything 'ugly' was not allowed to appear in officially published poetry. Yi Sha's poems could only appear in unofficial magazines at home and in 'ethnic' magazines abroad. In other words, he was forced to go unofficial at an early stage of his career. This changed in 1993, when one of his poems, 'Huangni jiezhi' 黄泥戒指 (A yellow-mud ring) was published by the most renowned official magazine, Poetry Periodical, followed by the publication of two of his other poems, including 'Esi shiren' 饿死诗人 (Starve the poets).

The Tiananmen Massacre in 1989 brought drastic changes to the political and cultural life of China. The event 'put an abrupt end to the cultural discussion of the 1980s; the idealism and utopianism that underscored the Age of Enlightenment evaporated'. ${ }^{85}$ Many intellectuals and writers were exiled and those that remained at home were disillusioned, which led to 'a mood that was more somber, pessimistic, and cynical' ${ }^{86}$ This situation lasted until Deng Xiaoping's Southern Tour Speech in 1992, when China set out on its road to a 'socialist market economy'. After a three-year period of political control when the unofficial magazines had to go underground again, the people-run publications reappeared but seemed to have lost their vitality and their influence had become far less than that of their precursors in the 1980s such as Today. Hai Zi's suicide

\footnotetext{
${ }^{85}$ Kang-I Sun Chang and Stephen Owen, eds. The Cambridge History of Chinese Literature, Vol. 2. Cambridge: Cambridge University Press, 2010, p. 667.

${ }^{86}$ Ibid.
} 
in 1989 looked like the last memory of the golden age of poetry. When Yi Sha published his first collection Esi shiren 饿死诗人 (Starve the poets) in 1994, he was facing a gradually commercialised society where poetry was increasingly marginalised.

Yi Sha participated in the Panfeng Conference in 1999 and was labelled a Minjian Poet, together with others of his group. Though he was one of the major members on the Minjian side, he was definitely not the focus of the Polemic, as Yu Jian and Han Dong were then considered as the leading figures of Minjian. However, Yi Sha gradually rose to prominence in the years after the Polemic with his continuous publications and energetic activities and became de facto the most representative minjian poet. After 2000, though Yi Sha's poems continued to appear in official literary magazines and officially published books, he never ceased to make use of the unofficial channels to publicise his works.

In the mid-2000s, when the world wide web became widespread in China, Yi Sha was among the first Chinese poets to utilize the technology to promote their writing. By this stage, Yi Sha was frequently associated with the Lower Body Poets, who established one of the most influential poetry website in China-Poetry Jianghu. In the forum of the website hosted by the Lower Body Poets, Yi Sha posted his new poems every month and frequently expressed his ideas on poetry writing. The website soon grew into a virtual gathering venue for many of the avant-garde poets, mostly minjian ones. Some of the poems they published online were so provocative that the website was shut down by the government in 2010. Apart from posting his works on the Internet, Yi Sha also published his Chinese poetry books overseas to avoid both censorship and the high expenses of publication in mainland China. For instance, his long poem Tang 唐 (Tang) was published by Otherland Publishing in Melbourne and his other long poem, Landeng 蓝灯 (Blue lamp), was published in Hong Kong. In the 2000s, he continued to publish his poetry through the official channels, which was easier for him than before, as he had become an established poet. However, his 'unofficial' publications, online and overseas, should be considered an integral part of his poetry activities. 
The minjian characteristics of Yi Sha were not only represented in his unofficial publications, but also in his insistence on his own poetic aesthetics, as well as his persistence in writing and developing Colloquial poetry. Translating Charles Bukowski and drawing inspiration from similar grassroot figures in Western poetry gave him more confidence in his own style. His new poetry books were published one after another in the 2010s, including his most important long poem Tang, a modern parody of the old version of Tangshi sanbai shou 唐诗三百首 (300 Tang poems), reviving the ancient poems in a new, postmodern context. He also coined an expression, 'poetry of facts' 事实的诗意, which became a key poetic notion among the Colloquial Poets. Meanwhile, his poems were translated into other languages and he was invited to poetry festivals around the world. In 2008, Bloodaxe Books, the UK's leading poetry publisher, published Yi Sha's collection, Starve the Poets, translated by Simon Patton and Tao Naikan. In this book, Yi Sha was described as 'the most controversial Chinese poet of the past 20 years, a member of the extreme avant-garde whose work has changed the face of Chinese poetry' ${ }^{87}$ Yi Sha was also invited to international events like the 38th Poetry International Festival Rotterdam in 2007, the 7th Aldeburgh Literary Festival in 2008 and the 50th Struga Poetry Festival in 2011.

In the 2010s, Yi Sha has been known as a major poetry activist who devotes himself to two unofficial poetry projects. 2010 and 2011 witnessed the launch of Yi Sha's two

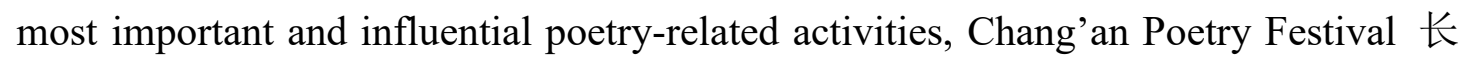
安诗歌节 and New Century Poetry Classics 新世纪诗典, which can be regarded as the models of the minjian poetry events with their strong unofficial elements, both aesthetically and institutionally. Chang'an Poetry Festival was established in 2010. Though it was named 'festival', it was in fact a regular private gathering of Yi Sha and his fellow poets to read and discuss poetry. However, it was more than a private poetry

\footnotetext{
${ }^{87}$ Yi Sha. Starve the Poets! Trans. Simon Patton and Tao Naikan. Northumberland: Bloodaxe Books, 2008, back cover.
} 
party, for it soon became so well-known in the poetry circles that many poets, once they go to Xi'an, would attend Chang' an Poetry Festival and this mode of organisation was imitated by unofficial poets in other parts of China. Chang' an Poetry Festival, though an unofficial organisation, has its own awards and regulations, and also collaborates with many other institutions such as universities to hold poetry events. These characteristics have blurred the demarcations between the official and the unofficial and made the cultural position of minjian increasingly ambivalent.

New Century Poetry Classics is yet another example of minjian courting the mainstream. It was originally Yi Sha's microblog that recommends to the reader one poem a day, selected from solicited or unsolicited submissions. It attracted numerous poets and poetry lovers to spread it and to make comments, becoming an influential online publication, especially for those who dislike the mainstream aesthetics of the official literary magazines. Later it became so popular and controversial that Yi Sha collaborated with Shen Haobo, his fellow Minjian Poet and one of China's most successful publishers, to publish an anthology every year. He also established a system of awards based on the New Century Poetry Classics and organised numerous poetry events.

The brief outline above portrays a poet whose career has been shaped by his ongoing engagement with the minjian movement. To Yi Sha, minjian is both an ideal and a strategy, and by accepting the title of minjian, he becomes both an opportunist and an idealist. He remains an outsider to the literary establishment, seeking to maintain his unofficial status both aesthetically and institutionally. He keeps writing Colloquial poetry, a controversial style that has never been fully accepted by the literary mainstream. An established poet as he is, he has never been a member of the Writers' Association. Not one to be content with a marginal status, he makes every effort to establish his own literary world. He uses digital technology and overseas channels to publish and promote his work and those of his peers, as a substitute for his limited space in the official literary world. The literary world he builds is fiercely unofficial, yet it 
mimics the official forms and procedures of the literary establishment. As I will demonstrate in the following chapters, the ambiguities and paradoxes of minjian, both as a cultural ideal and as a power strategy, are fully implicated in Yi Sha's poetry and literary activities. Yi Sha's efforts to 'mainstream' minjian have made him an unofficial hero, but also have brought him much controversy. 


\section{Chapter Two Minjian in Poetics: Yi Sha's Colloquial Poetry}

The Colloquial Poets that emerged in the 1980s are often regarded as the forerunners of minjian, and Colloquial Poetry is sometimes used interchangeably with minjian poetry. However, the word 'colloquial' in the colloquial poetics of minjian poetry can be misleading. What is colloquial about Colloquial Poetry? Even within the minjian camp, poets have different understandings of colloquialism and think differently about what remains at the core of their poetics. This chapter will focus on the aesthetic aspects of minjian by discussing the role of Colloquial Poetry in the formation of minjian poetics. Through close readings of Yi Sha's poetry as well as elaborations on Yi Sha's involvement with Colloquial Poetry, I explore three interrelated questions: On what grounds should Colloquial Poetry be understood as an anti-lyrical poetics beyond mere colloquialism? What are the distinctive features of Yi Sha's Colloquial Poetry? What is Yi Sha's contribution to the theorization of Colloquial Poetry?

\section{Colloquial Poetry Beyond Colloquialism: An Anti-Lyrical Poetics}

Colloquial Poetry appeared in the 1980 s as a trend of using colloquialisms in poetry with representatives like Wang Xiaolong, Yu Jian and Han Dong. However, it gradually acquired more characteristics than mere colloquialism and developed into a full set of earthly aesthetics. Yi Sha is an important contributor to the Colloquial poetics in its later period. Like many other terms that have been coined and become popular within Chinese poetry circles, kouyu shi 口语诗 (Colloquial Poetry) is also a loaded term that requires contextualisation and clarification. First, it is not composed by word of mouth and thus does not belong to the real oral tradition such as ancient epics and modern folk songs, but consists only of written literature with colloquial characteristics. Second, even within the confines of written literature, the colloquial characteristics of its language are also in doubt, as there is no distinct boundary between spoken and written 
words, between the informal and formal. A word can be regarded as informal in some circumstances while it may look formal in other circumstances. No poetry is written entirely in 'colloquial language' or 'written language'. Due to the vagueness of the term, Colloquial Poetry is rather a description of its external characteristics than a clear definition of its intrinsic quality.

Even Tang Xin, the author of Shuohua de shige 说话的诗歌 (The speaking poetry), the only monograph to date that focuses on the development of Chinese Colloquial Poetry, fails to give it a clear definition. In his book, he admits that 'it is impossible to identify who was the first to use this term' and that the frequent use of the term appeared in the discussions organised by some media like Poetry news in the 1980s, primarily referring to 'poetry written in colloquialism'. In the 1990s, and especially in the 2000s, the concept of Colloquial Poetry was roughly fixed. ${ }^{88}$ It is obvious that Tang treats Colloquial Poetry as a tendency to use colloquialism in poetry, which is only part of the whole picture, because there are many other features in this poetry. Tang further outlines the development of Chinese Colloquial Poetry by dividing the whole process into four phases: the first phase is from the early 1980s to 1984, which saw the birth of Colloquial Poetry; the second phase is from 1985 to 1989, and during this period Colloquial Poetry gradually came into shape; the third phase is from 1990 to 1998, when Colloquial Poetry persisted in a time when poetry was marginalised to a degree, and during which period Yi Sha appeared as a young and rebellious figure; the fourth phase is after the Panfeng Polemic in 1999, when the new generation of poets, such as Shen Haobo, joined the group and became prominent in the age of the Internet. Tang's book demonstrates a clear timeline of the history of Colloquial Poetry. However, the core issue, what Colloquial Poetry is, has not been fully discussed by him.

To understand Colloquial Poetry, according to its literal meaning, as poetry written in the oral language, using colloquialisms or common language, has its limitations. Such

${ }^{88}$ Tang Xin 唐欣. Shuohua de shige 说话的诗歌 (The speaking poetry). Beijing: Zhongguo shehui kexue chubanshe, 2012, p. 1. 
an understanding does not touch the core of this kind of poetry, for the use of colloquialisms in poetry is not a completely new phenomenon in Chinese. As Tang himself notes, there were a lot of colloquial elements in ancient writings, such as Classic of poetry and yuefu poems. In the Tang dynasty, Wang Fanzhi 王梵志, Hanshan 寒山 and Shide 拾得 also had a tendency to write poetry in the colloquial language, and Liu Yong 柳永, Li Qingzhao 李清照 and Xin Qiji 辛弃疾 of the Song dynasty often involved colloquial elements in their work. ${ }^{89}$ Then, what distinguishes these works from the Colloquial Poetry of the contemporary Chinese poets and of Yi Sha in particular?

Like Tang Xin in his monograph, Yu Jian's discussion of Colloquial Poetry also focuses mainly on the colloquial language. In 'Shige zhi she de ying yu ruan' 诗歌之舌的硬 与软 (The hard and soft tongues of poetry), Yu Jian argues that there have been two directions followed in the language of Chinese poetry since 1950s: 'hard tongue' and 'soft tongue'. The former refers to Putonghua 普通话 (modern Mandarin) and the latter to fangyan 方言 (dialects). Yu Jian equates fangyan with kouyu xiezuo 口语写 作 (colloquial writing). ${ }^{90}$ To him, Putonghua, the 'hard tongue', was established as a norm in the 1950s and was reinforced by Maoist discourse. It is a tongue associated with lyrical grandeur, using poetry as 'a tool to sublimate the world' 91 , with the examples of Obscure Poetry, Hai Zi's poetry and 'Intellectual Writing'. In contrast, fangyan or the colloquial writing, the 'soft tongue', is one connected with the common sense and private everyday life. Obviously, Yu Jian advocates fangyan or the colloquial writing. It is of note that, in his article, Yu Jian uses kouyuhua shige xiezuo 口语化诗 歌写作 (colloquialised poetry writing) instead of kouyu shi (Colloquial Poetry), which indicates that $\mathrm{Yu}$ Jian does not consider this as a particular type of poetry by the time of

\footnotetext{
89 Ibid, p. 1.

90 Yu Jian 于坚. 'Shige zhi she de ying yu ruan: guanyu dangdai shige de lianglei yuyan xiangdu’ 诗歌之舌的硬 与软: 关于当代诗歌的两类语言向度 (The hard and soft tongues of poetry: On two different directions in the languages of contemporary poetry). In Yang Ke 杨克, ed. 1998 Zhongguo xinshi nianjian 1998 中国新诗年鉴 (1998 yearbook of China's new poetry). Guangzhou: Huacheng chubanshe, 1999, p. 1.

91 Ibid, p. 5.
} 
the Panfeng Polemic, but primarily regards it as a trend of colloquialisation in poetry writing.

Yu Jian's article is a valuable contribution to the theoretical construction of Colloquial Poetry, though apparently, it is flawed. Dian Li has noted a logical problem in Yu Jian's discussion, pointing out that, though Putonghua and fangyan do form a binary pair, $\mathrm{Yu}$ Jian fails to demonstrate any necessary connection between fangyan and the colloquial writing. According to $\mathrm{Li}$, Yu Jian 'relies on the substitution of the colloquial with dialects to communicate his worthy pursuit of the colloquial writing, a substitution that [...] serves to reduce a very significant poetic question into an inoperably simple formula' ${ }^{92}$ Despite this logical problem, Yu Jian does make an important, though still problematic, differentiation between two types of tongues in poetry writing. More importantly, he associates the colloquial writing with the everyday, the quotidian, the common and the native. From this perspective, Yu Jian advances the understanding of Colloquial Poetry beyond the level of language by 1999.

In his summarisation of Colloquial Poetry, van Crevel uses the term 'Earthly' to capture not merely colloquialism in language but also a whole set of aesthetics, including characteristics such as 'quotidian', 'colloquial', 'anti, pre- or non-cultural', 'antilyrical', 'mundane' and 'ordinary'. ${ }^{93}$ These earthly qualities are characteristic of the Colloquial Poets, and strike a sharp contrast with the 'Elevated' poetics of the Intellectual Poets. Although van Crevel's categorisations run the risk of overgeneralisation and binary thinking, they are still effective in describing the aesthetic features of Colloquial Poetry beyond the level of language. I will use two poems, both on the theme of snow, to illustrate the different poetic orientations between the Intellectual and the Colloquial Poets. The first one is by Xi Chuan, a representative Intellectual Poet:

\footnotetext{
92 Dian Li. 'Naming and Antinaming: Poetic Debate in Contemporary China'. In Christopher Lupke, ed., New Perspectives on Contemporary Chinese Poetry. NY: Palgrave Macmillan, 2007, p. 197.

93 Maghiel van Crevel. Chinese Poetry in Times of Mind, Mayhem and Money. Leiden: Brill, 2008, p. 25.
} 


\section{Snow}

The basic meaning of snow is purity, but what it brings

Is absence: absence of starlight

Absence of horses' hooves clattering

In the cold streets and alleyways, absence of

The bright red nose of the courier coming from Chang'an

A crackling fire deepens the silence

The soul now has depth, like a well

Should someone venture to peer into it

He will not see himself

But another face that will astonish him

The snow that covers all things

Swirls above them like solemn music

The eyebrows of besieged warriors are frozen

Their hair turns gray, they have entered

The vast domain of what we call 'darkness'

The snow has brought absence, for this

The fire is singing its quiet song

Dawn sprouts silently, in your ears

There is only snow-you have not yet seen

Anyone to bring you charcoal on a snowy day

雪 
雪的本意是纯洁, 而它所带来的

是缺少, 缺少星光

缺少得得的马蹄声响在

寒冷的街巷, 缺少一个

鼻子通红, 来自长安的报信者

噼啪作响的炉火加深了寂静

灵魂有了深度，像一口井

如果有人敢于向其中探视

他不会照见自己

另一张面孔会叫他吃惊

覆盖万物的雪也旋舞在万物之上

像一首肃穆的乐曲

被围困的勇士眉毛结冰

头发灰白，进入了

我们称之为“黑暗”的广大领域

雪带来了缺少，对此

炉火低声吟唱着它的歌

黎明无声地萌动, 你的耳朵里

只有雪一一你还从未见过

一个雪里送炭的人 ${ }^{94}$

The second poem is by Yi Sha, who is representative of Colloquial Poetry:

\section{Police Car, Poet, Snow}

94 Xi Chuan 西川. 'Snow' 雪, trans. Tao Naikan and Tony Prince. The Poetry International Website: https://www.poetryinternational.org/pi/poem/15643/auto/0/0/Xi-Chuan/Snow/en/nocache, accessed 6 August 2019. 
one wintry day

in a swirl of mud and snow

a police car came screaming

along the street

insufferably arrogant

as usual

pushing and shoving

its way through traffic

the funny thing was that

no matter how smug it acted

it could not shake off

the coat of snow that covered it

and made it look identical

to every other car

all crawling like hearses

and that's why it was upset

as it passed by

a poet who happened to be

trudging across the road

got splattered from head to toe

with mud thrown up by its filthy wheels

what he saw

made him suddenly felt (sic) like crying

associating what he had just witnessed

with the ambiguous connection

between this police car

of the state

and the idea that

poetry is like snow 


\section{雪天里的几种事物}

雪天的街上

泥雪纷扬

一辆不可一世的

警车呼啸而来

还像平时一样

横冲直撞

好玩的是

它再得瑟

但却无法

抖落身上的雪妆

和所有的车辆

毫无区别

全像灵车

所以它急

这时候

一个被其

肮脏的轮子

溅了一身泥点

正从泥泞路上

跋涉而过的诗人

目睹此景

鼻子一酸

他联想起

诗歌如雪

与国家这辆警车的

暧昧关系 ${ }^{95}$

${ }^{5}$ Yi Sha 伊沙. 'Police Car, Poet, Snow' 雪天里的几种事物, trans. Simon Patton, Tao Naikan and Michael M. Day. The Poetry International Website: https://www.poetryinternational.org/pi/poem/10097/auto/0/0/Yi- 
The difference between the Elevated and the Earthly can be seen clearly in these two poems. Firstly, the two poets pay attention to the different aspects of snow. Xi Chuan thinks about 'absence', including 'absence of starlight,' of 'hooves clattering' and of 'the bright red nose of the courier coming from Chang'an'. All the items that attract his attention bear some romantic or nostalgic implications, as they are not from the here and now but are associated with either being lofty and above or from the remote past. This tendency to associate with objects and images higher than ordinary life also exists when he describes 'a crackling fire': he sees that 'the soul now has depth'. His focus then shifts to the inner world, having little to do with the surrounding reality he is in. In Yi Sha's poem, instead of 'purity', snow comes naturally with 'mud', then 'a police car came screaming'. In contemporary China's social context, the image of a police car always represents the state authorities and it is inevitably a reminder for the reader that this poem is about social reality. 'The funny thing was that / no matter how smug it acted / it could not shake off / the coat of snow that covered it / and made it look identical / to every other car / all crawling like hearses ...' These lines show Yi Sha's sarcastic tone when talking about politics. If snow is a trigger for $\mathrm{Xi}$ Chuan to question history, the soul, eternity and the meaning of life, it is then a metaphor for Yi Sha to present the immediate, somewhat muddy reality, a background for him to zoom in on the here and now.

Secondly, Xi Chuan's poem is connected by a number of images such as 'starlight', 'streets', 'courier', 'a crackling fire', 'face', 'warriors' and 'hair', while Yi Sha's poem concentrates on one central image 'a police car' and all other things move in a natural flow with it. The former is a combination of images and lyricism; the latter is more like narration and reasoning, closer to the witty thoughts of the common people.

Finally, from the perspective of translation, Xi Chuan's images and lyricism are 
arguably easier to translate and his poem works better in English translation. Such sentences as 'The snow has brought absence 雪带来了缺少' may look natural in English but sound quite unidiomatic in Chinese, for the native Chinese speakers tend to avoid abstract words and 'absence 缺少' is seldom used as a noun in such a way. In contrast, the language of Yi Sha is more idiomatic, natural and similar to the flow of daily conversations of common people, which is the primary reasons that he is called a Colloquial poet. However, the translators invented a new title, one other than Yi Sha's original one, which literally translates as 'A few things in a snowy day'. In its English version, the title becomes 'Police Car, Poet, Snow', a more specific title rather than the general 'few things'. This successful change shows that, though the language of Yi Sha's poetry is simple, it also requires subtle skills of the translator to achieve an ideal result.

The idea that Colloquial Poetry has an earthly aesthetics can also be found in Han Dong's early poetics. Though Han Dong, similar to Yu Jian, apparently stressed the importance of language, what he expressed was actually an anti-cultural attitude towards poetry. This anti-cultural attitude later became an important element in van Crevel's description of the Earthly poetics. In the 1980s, Han Dong made the wellknown claim 'Shi dao yuyan weizhi' 诗到语言为止 (Poetry ends in language), thereby stating clearly his attitude towards poetry: poetry is language itself and there is nothing else beyond language. Below is Han Dong's explanation in 1988, in his own words:

The purpose of poetry is language; poetry ends in language, which is to free language from all the concepts of utilitarianism. This 'language itself' has already existed, but only in poetry it becomes the sole object of experience.

诗歌以语言为目的, 诗到语言为止, 即是要把语言从一切功利观中解放出 来, 使呈现自身。这个“语言自身”早已存在。但只有在诗歌中它才成了唯一 
的 经验对象。96

Han Dong's extremist statement became so popular and widely cited that it was later mocked and parodied in such different versions as 'poetry ends in flesh', 'poetry ends in reading' and 'poetry ends in talking nonsense'. Han Dong's intended message is that the purpose of poetry is language itself rather than any other thing behind or beyond language, such as meaning and culture. Han Dong's own writing in the 1980s is considered an exemplar of anti-culture, anti-hero and anti-lyricism, which obviously gave inspiration to his younger fellow poet, Yi Sha.

The earthly features of Yi Sha's poems were present from an early stage and the most distinctive one is anti-lyricism. This feature brought him early fame, through poems like 'Starve the poets', one of his most anthologized short poems, as well as the namesake of his debut collection:

\section{Starve the Poets}

So easily you

begin to hold forth on the various aspects

of cultivation,

on the cycle of the seasons

You talk about pouring sweat the wheat harvest

Do you think of grains of wheat

as the tears you shed over women

and of their awns

as being soft as the pig-like bristles stuck on your chins?

That year you hit the roads

the northern wheat plants grew untended

\footnotetext{
${ }^{96}$ Han Dong 韩东. 'Zizhuan yu shijian’ 自传与诗见 (Autobiography and poetic views). Shige bao 诗歌报 (Poetry news), 6 July 1988, p. 3.
} 
Brandishing sickles

of sunlight

they cut their own stalks their throats

severing all final links with the earth

for you

You, poets, have eaten your fill

Vast fields of wheat

filled your bellies with their savour

The city's greatest spongers

then turned themselves into glorious farmers of verse

Wheat in the name of the sunlight, the rain

I call on you to starve them,

starve those fuckin' poets:

You can start with me first

a sidekick polluting this earth with ink

bastard of the art-world ${ }^{97}$

\section{饿死诗人}

那样轻松的 你们

开始复述农业

耕作的事宜以及

春来秋去

挥汗如雨 收获麦子

你们以为麦粒就是你们

为女人迸溅的泪滴吗

麦芒就像你们贴在腮帮上的

猪鬃般柔软吗

\footnotetext{
97 Yi Sha. Starve the Poets!, trans. Simon Patton and Tao Naikan. Northumberland: Bloodaxe Books, 2008, p. 26.
} 
你们拥挤在流浪之路的那一年

北方的麦子自个儿长大了

它们挥舞着一弯弯

阳光之镰

割断麦杆 自己的脖子

割断与土地最后的联系

成全了你们

诗人们已经吃饱了

一望无边的麦田

在他们腹中香气弥漫

城市中最伟大的懒汉

做了诗歌中光荣的农夫

麦子 以阳光和雨水的名义

我呼吁：饿死他们

狗日的诗人

首先饿死我

一个用墨水污染土地的帮凶

一个艺术世界的杂种 98

This poem was first published in Poetry Periodical in 1993 but was written in 1990, after the death of Hai $\mathrm{Zi}$. It was unique at that time and has become Yi Sha's label to some extent. When Yi Sha's poetry collection in English translation came out in 2008, this poem also became the title of the book.

Thematically, this poem is generally considered a revolt against the fashion of imitating $\mathrm{Hai} \mathrm{Zi}$ in poetry at the time. Hai $\mathrm{Zi}$, one of the most famous lyrical poets in mainland China after the Cultural Revolution, committed suicide on 26 March 1989. In Hai Zi's poetry, 'wheat field' is a frequently used image. After his death, the image of the wheat

\footnotetext{
98 Yi Sha 伊沙. Esi shiren 饿死诗人 (Starve the poets). Beijing: Huaqiao chubanshe, 1994, p. 3.
} 
field became omnipresent in the poems published in magazines. A great number of poets were imitating Hai Zi's lyrics and images. As one of the most influential poets at that time, Hai Zi had a great impact on the poetry circles by his lyrical poetry and life tragedy. His poetry and suicide were admired and exalted to the highest degree, and became part of what Michelle Yeh has called the 'cult of poetry' in the early 1990s. Yi Sha wrote 'Starve the poets' as a response to the phenomenon, as he explains, 'On the Chinese poetry scene, what you could see in the journals was "wheat field". Under Hai Zi's influence, all the people wrote about the wheat field, the agricultural imagery. I was very angry about this poetry, which was why I wrote "Starve the poets". 99

In her seminal article, Yeh points out that there was a phenomenon and a concomitant discourse in the 1980s and 1990s that 'bestowed poetry with religious significance' ${ }^{100}$ The reasons are manifold, including political, economic and cultural factors. The repressive political environment, the cruelty of the rising 'commodity economy' and the sense of crisis caused by the marginalisation of avant-garde poetry all led to this poetic religion. The image of the poet became linked with a certain religious spirit. Hai $\mathrm{Zi}$, after his suicide, became a 'cult hero' on the unofficial poetry scene in China and was compared to a saint, considered lofty and worshiped by numerous young people. His poetic style was also imitated by his contemporaries and followers. Interestingly but understandably, it was the Colloquial Poets, the believers in the earthly and the destroyers of the sublime, who first criticised this phenomenon as a 'cult'. According to Yeh, Yu Jian was among the first to criticise the 'cult of poetry' as the 'Maoist way of thinking'. ${ }^{101}$ Yeh's article was published in 1996, but she had already found that 'besides critiques from such poets and critics as Yu Jian, Wang Gan, and Bei Ling, Yi Sha's poetry stands out as a parody of the "cult of poetry", which places an aura around the poet [Hai Zi]. ${ }^{102}$ Undoubtedly, 'Starve the poets' is a representative instance to

\footnotetext{
99 Yi Sha, Interviewed by Liang Yujing, 2016, see Appendix.

100 Michelle Yeh. 'The "Cult" of Poetry in Contemporary China'. The Journal of Asian Studies, Vol. 55, No. 1 February 1996, p. 52.

101 Ibid, p. 74.

102 Ibid, p. 78.
} 
support Yeh's comment.

Ironically, 'Starve the Poets' seems not a typical 'anti-lyrical' poem but looks rather lyrical, at least in the opening lines. With emotional and factual descriptions in addition to rhetorical questioning, Yi Sha seems to start the poem in the vein of Hai Zi, like many of his followers. The language is not so colloquial as that of his other poems, but includes a few rhetorical expressions such as 'being soft as the pig-like bristles'. This poem is not anti-lyrical itself, but it serves as a manifesto of anti-lyricism, anticipating the author's anti-lyrical style in many other later poems. In 'Starve the poets', Yi Sha openly and directly announces his anti-lyrical attitude in a somewhat lyrical manner. What he opposes is not only the cult of Hai $\mathrm{Zi}$ and the prevailing fashion generated by Hai Zi's followers, but also the lyrical style that dominates the post-Hai Zi period on the Chinese poetry scene, a style characterized by lyrical expressions and agricultural images such as 'wheat fields', together with an over-sentimental pursuit of the lofty, the elevated and the sublime. Yi Sha deems all this as hypocritical and obsolete, calling for a new poetry that shifts its focus from the rural areas to the city, from the sublime to the ordinary, from lyrical to anti-lyrical. In his eyes, 'wheat' is just wheat, a kind of grainit is ridiculous that the poets see the plant as a symbol for something lofty and eternal, an object onto which to project their affections. Thus, he shouts out his angry call to the wheat: 'Starve them, starve those fuckin' poets!' As the poem goes on, the initial lyrical tone gradually gives way to an anti-lyrical one, and the ending reveals Yi Sha's humour when he includes himself in the poets he criticises: 'a sidekick polluting this earth with ink / bastard of the art-world'. To include himself into the target of his criticism is also declaratory and can be regarded as a reminder for the poet to walk forward without hesitation on his own way.

With 'Starve the poets' as a manifesto, Yi Sha began to create a new poetics for Colloquial Poetry. In my view, Yi Sha's Colloquial Poetry should not be understood as the mere colloquialization of language but as a complex poetic system that is both a worldview and an artistic technique. Through the simplification of form and language, 
he imbues his poetry with stimulating ideas and avant-garde techniques. He has become a unique figure since the 1990s.

\section{Yi Sha's Poetry: Profanity, Playfulness, Political Incorrectness}

Yi Sha's resolution to break new ground is succinctly expressed in a two-line poem 'Mingpian' 名片 (Name card): 'You may be So-and-So's son-in-law / but I am Father to myself 你是某某人的女婿 / 我是我自个儿的爹. ${ }^{103}$ Though writing in the style of Colloquial Poetry, Yi Sha self-consciously distinguishes himself from his precursors such as Wang Xiaolong, Yu Jian and Han Dong. In this section, I will discuss three major characteristics of Yi Sha's poetry: profanity, playfulness and political incorrectness. These characteristics are not separate but overlap with each other, making Yi Sha's poetry a distinctive presence on the Chinese poetry scene.

\section{Profanity}

Profanity, as a feature of Yi Sha's poetry, can be perceived on many levels. Yi Sha's profanity is closely associated with the broader anti-cultural tendencies in the poetic discourse of the Colloquial Poets. To the Colloquial Poets, culture is not a positive word, and they generally see culture as an undesirable element in poetry and think of good poetry as one free from the burden of too much culture. As van Crevel suggests, the earthly aesthetics stands for 'anti, pre- or non-cultural'. ${ }^{104}$

It should be noted that, though the Colloquial Poets are generally anti-cultural in their poetics, the degree differs from person to person. 'Anti-cultural' is not an absolute adjective but a gradable one. For instance, Yu Jian's poetry is usually considered to

\footnotetext{
103 English translation from Yi Sha. Starve the Poets!, trans. Simon Patton and Tao Naikan. Northumberland: Bloodaxe Books, 2008, p. 38. Chinese text from Yi Sha 伊沙. Esi shiren 饿死诗人 (Starve the poets). Beijing: Huaqiao chubanshe, 1994, p. 89.

104 Maghiel van Crevel. Chinese Poetry in Times of Mind, Mayhem and Money. Leiden: Brill, 2008, p. 25.
} 
contain more cultural and historical elements, whereas poems by Han Dong and Yi Sha are closer to everyday life, appearing as a deconstructor or even destroyer of traditional Chinese culture. Thus, the two poets are 'earthlier' than poets like Yu Jian in this regard.

Yi Sha's proclivity towards the profane became evident in his early work, 'Crossing the Yellow River', a poem written during his undergraduate years. This poem, due to its rebellious content, was not published in any official literary magazine for nearly twenty years after it was written, until a retrospective exhibition in Shanhua 山花 (Mountain flowers) in 2012. However, it had become famous, or perhaps infamous, in the avantgarde poetry circles long before that. The poem reads as follows:

\section{Crossing the Yellow River}

As the train was passing over the Yellow River

I was in the toilet having a piss

Oh, I knew I was being remiss

I should have been sitting at one of the windows

or standing by a door of the carriage

left hand on my hip

shielding my eyes with my right hand

gazing out like some Great Man

or like a poet, at the very least

recalling some anecdote connected with this river

or some episode from its history

Just then, everyone was gazing out the window

while I was in the toilet

for what seemed like ages

for my time had come

I had waited 24 hours for this

but in the time it took to have a piss 
I'd left the Yellow River a long way behind me ${ }^{105}$

\section{车过黄河}

列车正经过黄河

我正在则所小便

我深知这不该

我 应该坐在窗前

或站在车门旁边

左手叉腰

右手作眉檐

眺望 象个伟人

至少象个诗人

想点河上的事情

或历史的陈帐

那时人们都在眺望

我在则所里

时间很长

现在这时间属于我

我等了一天一夜

只一泡尿功夫

黄河已经流远 ${ }^{106}$

This poem, though generally known within the avant-garde poetry circles as one of the most daring and 'unblushing' poems, is often regarded as an imitation of Han Dong's masterpiece 'Youguan Dayanta' 有关大雁塔 (Concerning the Wild Goose Pagoda). Han Dong's poem deconstructs all the cultural and historical symbolism associated with the Wild Goose Pagoda, a famous historical construction in Xi'an which dates back to

105 Yi Sha. Starve the Poets! Trans. Simon Patton and Tao Naikan. Northumberland: Bloodaxe Books, 2008, p. 19. 106 Yi Sha 伊沙. Esi shiren 饿死诗人 (Starve the poets). Beijing: Huaqiao chubanshe, 1994, p. 5. 
the Tang dynasty. Han wrote the poem with an intent to deprive the ancient pagoda of its cultural significance, one that usually evokes romantic and heroic emotions in the tourists, and instead concentrated his poetic thoughts on the prosaic fact that the Wild Goose Pagoda is just a pagoda and nothing beyond that. People were coming to visit the relic imbued with ideas of heroism, but this heroism will not make them heroes. In the concluding lines of Han's poem is found a typical expression of his anti- or noncultural stance, revealing his earthly poetics:

\author{
concerning the Wild Goose Pagoda \\ what can we know \\ we climb to its top \\ look around the scenery \\ then go down
}

\title{
有关大雁塔
}

我们又能知道什么

我们爬上去

看看四周的风景

然后再下来 107

Yi Sha takes up Han Dong's deconstructive strategy in 'Crossing the Yellow River'. The Yellow River, considered as the 'mother river' of the Chinese civilisation, is a much grander and more striking target than the Wild Goose Pagoda, if one's aim is to undermine the age-long Chinese obsession over their civilization's achievements. Yi Sha's poem is a response to Han's piece, although a more daring and radical challenge to Chinese popular beliefs. The first two lines juxtapose two places to create instant drama: 'I' am on the Yellow River, but 'I' am also in the toilet on the train. The tension

\footnotetext{
107 Han Dong 韩东. 'Youguan Dayanta' 有关大雁塔 (Concerning the Wild Goose Pagoda). Zhonghua shiku: Han Dong shixuan 中华诗库: 韩东诗选 (Collections of Chinese poetry: Han Dong), http://www.shigeku.org/shiku/xs/handong.htm\#14, accessed 17 May 2017.
} 
of the two locations, the Yellow River versus the toilet on the train, immediately indicates that this poem contains a certain profanity, as the Yellow River is considered sublime and almost divine in Chinese culture while the toilet is dirty and involved with the act of excretion. The next few lines issue further iconoclastic images, in a tonguein-cheek way: 'I should have been sitting ... / or standing ... / left hand on my hip / shielding my eyes ... like some Great Man.' The 'Great Man' here is obviously Mao Zedong 毛泽东, for this image of Mao was all too familiar to the entire Chinese population. But the poem did not attack him alone. The 'great leader's' pose was intended as a satire at the conventional exaggeration in communist propaganda, the inclination for the lofty and the sublime. What Yi Sha mocks is not simply the Chinese communist practice of politics but more saliently the aesthetics of the Chinese communist culture since the founding of the PRC in 1949. Apart from that, he also mocks the fondness for being pretentious and sentimental in recent Chinese lyrical tradition. So he adds in haste: 'or like a poet.' The ending is both wicked and shrewd: Unlike others who 'gaze out the window' to enjoy the view of the Yellow River, 'I' is concerned with something more personal, trivial but urgent, for the 'I' have waited 24 hours for the chance to piss.

Though the poem ends with a sentence of fixed meaning (a person pissing on the Yellow River), its implication is profound and multileveled. Its cultural profanity is a radical subversion to both the political ruling elites and the cultural establishments, such as the poetry circles. In 1990, the then poetry circles had yet to get used to such indecent descriptions in poetry as 'pissing'. Worse still, this 'pissing' is to piss at one of the most revered cultural icons. Thus, Yi Sha goes further than Han Dong in the deconstruction of culture.

'Crossing the Yellow River' can certainly be considered as the manifesto of the anticultural aesthetics of Colloquial poetry. The deliberate nastiness of the poem is not just a gimmick but a statement of Yi Sha's artistic view. The difference between 'I' and other people can be understood on the aesthetic level. When the others look out the window 
and become fascinated by the river view, the 'I' is busy relieving himself in the toilet, a calculated, ostentatious gesture to show his own priority. If we keep in mind Colloquial Poetry and its proclaimed earthliness, Yi Sha's poem also implies that the practice of everyday life is more important and deserves more attention than romantic fantasies, and that his focus is on the personal, the private, rather than on the grand, the elevated objects of cultural grandeur.

References to pissing, the major source of profanity in 'Crossing the Yellow River' are harbingers of Yi Sha's obsession with body writing and his subsequent association with the Lower Body Poets of the 2000s. Body writing, a literary trend that focuses on depicting bodily functions, is not a new phenomenon in contemporary Chinese literature. It was started in fiction by women writers in the $1980 \mathrm{~s}$ and became a prominent phenomenon in Chinese poetry in the 1990s, especially in the writing of the Colloquial Poets. In Van Crevel's analysis of the earthly aesthetics, the Earthly stands for 'body', whereas the Elevated denotes 'mind'. ${ }^{108}$ However, according to Dong Yingchun 董迎春, body writing in poetry in the 1990s is a cultural strategy to 'deconstruct, subvert, dispel and decentralize the political and moral discourse led by the political ideology'. ${ }^{109}$ He further argues that 'body writing is not a privilege of the Minjian writing ... It frequently appeared in the Minjian writing in the 1990s. Meanwhile, it also appeared in the Intellectual writing that was different from the Minjian writing.' ${ }^{110}$ The Intellectual Poets like Bai Hua 柏桦, Ouyang Jianghe, Xiao Kaiyu 肖开愚 and Chen Dongdong also have produced works that contain elements of body writing. Nevertheless, the body writing of the Intellectual Poets is decorated with implicit images and metaphors and thus the presentation of the body is generally not as obvious as that in the colloquial writing.

\footnotetext{
108 Maghiel van Crevel. Chinese Poetry in Times of Mind, Mayhem and Money. Leiden: Brill, 2008, p. 25.

109 Dong Yingchun 董迎春. 'Lun 20 shiji 90 niandai shige wenxue yu wenhua de guanxi' 论 20 世纪 90 年代诗 歌文学与文化的关系 (The relationship between poetry and culture in the 1990s). Gaoxiao sheke dongtai 高校社 科动态 (Social sciences perspectives in higher education), No. 4, 2015, pp. 29-30.

110 Ibid, 30.
} 
It is the appearance of a few 'beautiful women writers' 美女作家 who made this term the focus of criticism at the turn of the century. Their representatives include Wei Hui 卫慧, Mian Mian 棉棉, Jiu Dan 九丹 and Chun Shu 春树 (aka. Chun Sue). ${ }^{111}$ The most notable phenomenon of body writing in contemporary poetry took place almost simultaneously with the rise of the female novelists. In 2000, a group of poets such as Shen Haobo, Yin Lichuan 尹丽川, Wu Ang 巫昂 and Nan Ren 南人 established an unofficial magazine, Xiabanshen 下半身 (Lower Body) and the website, Poetry Jianghu. They gradually formed one of the most controversial poetry groups of recent decades, as they produced poems 'close to the flesh' 贴近肉体 and pursued 'the presence of the flesh' 肉体的在场感. ${ }^{112}$ Contrary to the female dominance of body writing in fiction, the most influential and controversial figure in poetry on the body is undoubtedly Shen Haobo, a male poet, though Yin Lichuan and Wu Ang, two female poets, have also drawn much attention. Shen's role in the body writing trend at the turn of the century is a double one: he is not only the leading Lower Body Poet himself but also the publisher of Chun Shu's Beijing wawa 北京娃娃 (Beijing doll). ${ }^{113}$ Thus, to some extent, Shen participated in the body writing trend in both poetry and fiction.

At least two poets influenced the Lower Body movement. One is the ChineseAustralian poet, Ouyang Yu, author of B xilie B 系列 (B Series), a sequence of poems playing with ' $\mathrm{B}$ ', a letter whose pronunciation is identical to the female sexual organ in Chinese. When he was in Beijing in 1999 as the writer-in-residence at Peking University, Shen Haobo visited him and highly praised $B$ Series, just one year before the Lower

\footnotetext{
111 Wei Hui’s Shanghai baobei 上海宝贝 (Shanghai baby) was published in 1999, Mian Mian’s Tang 糖 (Sugar) in 2000, Jiu Dan's Wuya 乌鸦 (Crows) in 2001 and Chun Sue’s Beijing wawa 北京娃娃 (Beijing doll) in 2002. Most of these books were banned soon after their publication because of their erotic content and 'unethical' ideas. However, the banning of their books brought them more attention and made them more popular at home and abroad. For instance, Chun Sue became the cover girl of TIME Magazine in 2004 and the other writers' books were all translated and published in many languages.

112 Shen Haobo 沈浩波. 'Xiabanshen xiezuo ji fandui shangbanshen' 下半身写作及反对上半身 (Lower body writing and anti-upper-body-ism). Shikan 诗刊 (Poetry periodical), No. 8, 2002, p. 79.

113 Strictly speaking, Shen Haobo is more like Chun Sue's agent, who discovered her manuscript and helped get it published. Shen's company Xiron 磨铁 is a private one that made and distributed the book but had to publish it with an ISBN from a state-run publishing house and under the latter's name. That is the tricky situation in China's publishing industry.
} 
Body movement took off. ${ }^{114}$ The other poet who influenced the movement is Yi Sha, who has been Shen Haobo's poet friend since Shen's undergraduate years. Shen exchanged correspondence with him and obviously admired him very much.

Yi Sha is an advocate of body writing and sees the body as an important element of the avant-garde poetic sensibility. In 2000, when talking about the Lower Body group, he said:

The emphasis on the lower body, to my understanding, is in essence on the cock.

Not hips, nor legs, nor feet, nor the emphasis on the whole half part of the body $[\ldots]$

To construct a writing with body needs to go directly to the cock, or to put it more politely, to go back to the root of life and set out again-Chinese poetry has to start again from this point.'

我理解对下半身的强调本质上是在强调鸡巴。

不是胯，不是腿，不是脚，也不是对这半截整体的强调......

建设一个有身体的写作必须直捣鸡巴, 说得好听点儿就是回到生命的 根部出发一中国诗歌在这一点上需要从头再来。115

He praised the Lower Body group as avant-garde and said that he was 'seeking to join' 寻求加入. ${ }^{116}$

\footnotetext{
114 Ouyang Yu 欧阳昱. 'Shuangyu rensheng' 双语人生 (Living a bilingual life). Huawen wenxue 华文文学 (Literature in Chinese), No. 5, 2014, p. 36.

115 Yi Sha 伊沙. 'Wo suo lijie de xiabanshen he wo' 我所理解的下半身和我 (The Lower Body and myself to my understanding). In Yi Sha 伊沙, Zhongguo xiandai shilun 中国现代诗论 (On modern Chinese poetry), Taipei: Showwe Information, 2011, p. 233.

116 Ibid, p. 235.
} 
Undoubtedly, in body writing, Shen Haobo and the Lower Body group go further than Yi Sha in their presentation of the body and the description of human desire. In Yi Sha's poetry, though the body appears frequently, it appears under artful control. This does not mean Yi Sha is not brave enough to confront the direct presentation of human desire. But, unlike Shen Haobo, Yi Sha often puts his body writing in a dramatic scene and narrates with aloofness. He is not so much interested in exposing the self, even if sometimes his narrator in the poem is ' $\mathrm{I}$ '. What he is interested in is not the expression of his own bodily desire but rather seeks to use the body as a means to an end, such as deconstructing cultural conventions. In 'Crossing the Yellow River', the man pissing on the Yellow River is more an iconoclastic gesture than a fixation on the male sexual organ.

The poem 'Yangwei huanzhe de huiyi' 阳萎患者的回忆 (Memory of an impotency sufferer) is another case in point:

\section{Memory of an Impotency Sufferer}

Her habit in copulation

caused my softness.

Her habit in copulation

broke Heaven.

This deadly woman,

I didn't see her face clearly.

Messy clothes on the chair back.

There was a scream when she came.

She cried out the Führer's name

with extraordinary pleasure.

That sharp cry

caused my softness.

I'm not a Jew 
but have the softness of mankind.

\title{
阳萎患者的回忆
}

\author{
她在交媾中的习惯 \\ 造成了我的软 \\ 她在交媾中的习惯 \\ 石破惊天 \\ 这要命的女人 \\ 我未能看清她的脸 \\ 零乱的衣衫搭在椅背上 \\ 她在高潮中有一声喊 \\ 喊着元首的名字 \\ 显得异常快感 \\ 这尖锐的一喊 \\ 造成了我的软 \\ 我不是犹太人 \\ 但有着人类的软 117
}

The poem is about lovemaking, a typical theme of body writing. However, Yi Sha creates a dramatic scene where the narrator ' $I$ ' is obviously not the poet himself. Like many other poems of body writing by Yi Sha, the lovemaking in this poem bears some other implications, both cultural and political. The title indicates the poem has a particular setting, namely the story of an impotency sufferer, and how his impotence comes about. The opening lines clearly states that it is her 'habit' in sex that causes 'my softness'. The word 'habit' denotes it is not one incident but a behaviour that happens repeatedly. 'This deadly woman, / I didn't see her face clearly' implies that it is not a certain person but a more general reference. These elements reveal this is a poem about

117 Yi Sha 伊沙. Esi shiren 饿死诗人 (Starve the poets). Beijing: Huaqiao chubanshe, 1994, p. 38. 
culture rather than a personal incident, which becomes apparent in 'She cried out the Führer's name / with extraordinary pleasure.' The Chinese word yuanshou 元首 gives the reader the immediate association of Adolf Hitler, for it is not a common title for a political leader.

Erotica is often used by writers and poets as a means to resist totalitarianism and subvert the authorities. Similar scenarios can be found in Alexander Solzhenitsyn's Cancer Ward and Yan Lianke's 阎连科 banned novella Wei renmin fuwu 为人民服务 (Serve the people). Crying out the Führer's name in sex gives the woman 'extraordinary pleasure', which is both absurd and understandable. Luo Zhenya argues this poem reveals 'a naughty and cunning mind to play with the leader and authority'. ${ }^{118}$ This comment is true up to that particular line. However, the last two lines take a turn to a more profound tone. 'I'm not a Jew / but have the softness of mankind' confirms the previous yuanshou is Hitler and 'the softness of mankind', a serious phrase, gives this poem a much deeper meaning than a mere mocking of authority. The impotence in this poem becomes a symbol for the weakness of humankind when faced with dictators.

In other poems Yi Sha continued his body writing in a humorous and seemingly lighthearted way, like a storyteller narrating stories of the body, the flesh and human desire. As always, he distances himself from the narrated events in these poems as a clever witness, sometimes mocking, sometimes sympathizing, sometimes commenting. He seldom writes about his own body but is never hesitant to expose the bodies of his characters. In 'Baojing rensheng' 包茎人生 (Foreskinned life), he depicts an unvalued surgeon whose work is to cut off a hundred foreskins every day. 'gee! so many foreskins / like useless daggers / that have nowhere to stab / hopelessly waiting in the sheaths / or buddhist monk's heads / crowded with steel helmets / like the life of all of us.' 噢!

\footnotetext{
${ }^{118}$ Luo Zhenya 罗振亚. “'Hou xiandai’ lushang de gujue tanxian: 1990 niandai Yi Sha shige lun” “后现代”路上 的孤绝探险—1990 年代伊沙诗歌论 (A lonely exploration on the “postmodern” road: Yi Sha's poems in the 1990s). Guangdong shehui kexue 广东社会科学 (Guangdong social sciences), No. 4, 2013, p. 169.
} 
这么多的包茎 / 如同一把把无用武 / 之地的七首 / 干等在刀鞘里 / 抑或是一 排排 / 顶着钢盔的和尚头 / 如同我们大伙的人生 ${ }^{119}$ But Yi Sha's anti-cultural tone reappears as follows: "which is the idea of a poet / as a doctor / $\mathrm{i}$ have become numb long before.' 这是诗人的想法 / 作为医生 / 我早已麻木不仁 ${ }^{120}$ Then, the surgeon who is not satisfied with life takes great pleasure in dealing with foreskins:

i have to throw away bucket after bucket of foreskins

and then wash my hands i'm so fucking happy

which you can see

from the smile on my face when i receive my salary ${ }^{121}$

\author{
只是每日下班前 \\ 我把一桶桶包皮倒掉 \\ 然后洗手 真他妈幸福 \\ 你从我领取工钱时的微笑中 \\ 即可看出 ${ }^{122}$
}

Such humorous and sarcastic treatment of a grotesque theme can be also found in 'Gong zhong' 宫中 (In the palace), where the 'I' becomes a young eunuch who waits outside the curtain, listening to the emperor 'biting' at a woman's bound foot: 'For how many years / will he keep biting at a human trotter? 一只人蹄 / 得啃多少年? ${ }^{123}$ In 'Huangshan zhi shang' 荒山之上 (On the barren mountain), the protagonist discovers a used condom and suddenly finds the world becomes 'kind of interesting' 有了点意 思: 'Until the sun set / I squatted on the slope / doing the job of an archaeologist' 太阳 下山以前 / 我就一直蹲在山坡上 / 干着考古学家的行当. ${ }^{124}$ In 'Gudu de

\footnotetext{
119 Yi Sha, Shu Cai and Yang Xie. Poems of Yi Sha, Shu Cai \& Yang Xie, trans. Ouyang Yu. Newtown NSW:

Vagabond Press, 2012, p. 58.

${ }^{120}$ Ibid, p. 58.

${ }^{121}$ Ibid, p. 58.

122 Yi Sha 伊沙. Esi shiren 饿死诗人 (Starve the poets). Beijing: Huaqiao chubanshe, 1994, pp. $39-40$.

123 Ibid, p. 77.

124 Ibid, pp. 91-92.
} 
muyangren’ 孤独的牧羊人 (The lonely shepherd), Yi Sha writes about a New Zealand film, in which a lonely shepherd 'fucks three ewes', and comments: 'This film / is very beautiful and touching / not suitable for children' 这部片子 / 拍得很美 很 感人 / 少儿不宜. ${ }^{125}$

As a form of Yi Sha's profanity, body writing is one of the indispensable elements that constitute Yi Sha's earthly poetics and his idea of the avant-garde. His treatment and presentation of the body pushed further the boundaries of Colloquial Poetry in the early 1990s. Moreover, Yi Sha's body writing is always underscored with sharp, and sometimes biting, intellectual insights. Yi Sha's presentation of the body makes a considerable contribution to the Colloquial poetics. His poems also have given inspiration to the Lower Body group, who produced poems with more confessional and erotic inclinations in the early years of the twenty-first century, this even though Yi Sha's own body writing is far less confessional and has little to do with bodily desires.

\section{Playfulness}

Playfulness, an essential element of Yi Sha's poetry, is closely related to his label of 'postmodernism'. Yi Sha's work is labelled by critics like Luo Zhenya as 'postmodern writing, ${ }^{126}$ partly because of his deconstruction and subversion of culture, and partly due to the playfulness of his poetry. In Yi Sha's poetry, the omnipresence of different kinds of wordplay has become a distinctive feature. Why is Yi Sha so interested in wordplay? And what is the connection between the playfulness of his work and the Colloquial poetics? The first question can be explained by Yi Sha's persistent pursuit of the 'avant-garde' and of creating something new, something different from the mainstream. To his understanding, " "playing” is always serious, and it is the supreme

\footnotetext{
125 Yi Sha 伊沙. Yezhong zhi ge 野种之歌 (Song of a bastard). Xining: Qinghai renmin chubanshe, 1999, p. 94.

${ }^{126}$ Luo Zhenya 罗振亚. “'Hou xiandai’ lushang de gujue tanxian: 1990 niandai Yi Sha shige lun” “后现代”路上 的孤绝探险—1990 年代伊沙诗歌论 (A lonely exploration on the “postmodern” road: Yi Sha's poems in the 1990s). Guangdong shehui kexue 广东社会科学 (Guangdong social sciences), No. 4, 2013, p. 165.
} 
state of writing, “玩” 从来都是严肃意义上的, 是写作的至高境地. ${ }^{127}$ As for the second question, playfulness in writing can be regarded as a form of resistance to the official aesthetics that advocates the lofty, the serious and the politically correct. In this sense, Yi Sha's playfulness is not only a matter of personal taste but a deliberate cultural revolt against the established poetic values.

In 'Zhiming de cuobiezi' 致命的错别字 (The fatal typo), a deliberate typo makes the poem vivid and humorous:

\section{The Fatal Typo}

I see the deer galloping

like homeless dogs.

The westering sun suddenly stops.

The clouds fall down.

A deep-sworn-vow-like roar

comes from across the river

from the depths of the savanna.

At the centre of the land,

in the trembling eyes of a little deer,

a shizi's golden mane whips.

The king of beasts is getting up

with a causal yawn.

\section{致命的错别字}

我看见鹿群的狂奔

\footnotetext{
127 Yi Sha 伊沙. 'Esi shiren, kaishi xiezuo' 饿死诗人, 开始写作 (Starving the poets and starting to write). In Yi Sha 伊沙. Esi shiren 饿死诗人 (Starve the poets). Beijing: Huaqiao chubanshe, 1994, p. 172.
} 
如丧家之犬

西沉的太阳突然停顿

云彩芏落

一记山盟海誓的怒吼

来自河的对岸

来自草原深处

大地的中央

在小鹿颤抖的目光上

一头虫子金发飘扬

兽中之王正在起床

随便打了一个哈欠 ${ }^{128}$

In this poem Yi Sha depicts the grassland landscape. When a lion gets up, other animals and nature itself are all startled, such as deer galloping away like homeless dogs, the westering sun suddenly stopping and the clouds falling down from the sky. However, what makes this poem extraordinary is a deliberate typo shizi 䖝子 (louse), which is identical in pronunciation to 'lion'. Logically, the word in this place should be a 'lion', the king of beasts whose golden mane whips, whose yawn startles all the other animals on the grassland. By using a homophone, Yi Sha makes a creative mistake which gives this poem vitality and energy. Turning a 'lion' to a 'louse' not only has some absurd, humorous effect, but creates a tension between the two words, as a lion is so huge and a louse is so tiny. Without the deliberate mistake, the poem would lose its poetry. Just as 'St-stammering, St-stuttering' is based on a broken language, this poem is a product of a typo. Again, Yi Sha turns something 'bad' into good poetry.

In 'Fandong shisihang' 反动十四行 (A reactionary 14-line poem), Yi Sha continues to mock the romantic lyricism by writing a '14-line poem' himself:

128 Yi Sha 伊沙. Esi Shiren 饿死诗人 (Starve the poets). Beijing: Huaqiao chubanshe, 1994, p. 87. 


\section{A Reactionary 14-Line Poem}

at this noon a white day in sunlight

suddenly something sour in me is about to pour out

more urgent than diarrhoea so fierce I'm in a hurry

to knock open the door of poetry the 14-line poem

is a bedpan exquisite good-sized

fit for weeping out to more snot than tears

girls flowers death unrecognizable gods

will I have to stick to this kind of thing?

the romantic feelings of a rough man

make occasional pieces too banal scorned by gentlemen

or outstanding it just shows how rough it can be

draw near to the ending like a real expert I also know

I must save up enough strength deep breath eat two buns

go to the toilet oh my god too much too much

I write this 14 -line poem to the 15 th line at one go

\section{反动十四行}

在这晌午 阳光底下的大白天

我忽然有一肚子的酸水要往外倒

比泻肚还急 来势汹汹 慌不择手

敲开神圣的诗歌之门十四行

是一只便盆 精致 大小合适 


\section{正可以哭诉 鼻涕比眼泪多得多}

少女 鲜花 死亡 面目全非的神灵

我是否一定要倾心此类

\section{一个粘老爷们儿的浪漫情怀}

造就偶尔的篇章 俗不可读 君子不齿

或不同凡响 它就是表现如何的粘

\section{进入尾声 象一个真正的内行 我也知道 \\ 要运足气力 丹田之气 吃下两个馒头 \\ 上了一回则所 不得了 过了 过了 \\ 我一口气把十四行诗写到了第十五行 ${ }^{129}$}

This poem is a mockery of romantic lyricism. The European sonnet, widely known in Chinese as 'shisihangshi' 十四行诗 (the 14-line poem) or 'shanglaiti' 商籁体 (a transliteration of 'sonnet'), was introduced to China in the 1920s. In the 1930s, a great number of Chinese sonnets were published in the important newspapers and magazines of the day and this became an influential literary genre, with notable poets such as Zhu Xiang 朱湘, Sun Dayu 孙大雨 and Bian Zhilin 市之琳. The first collection of Chinese sonnets was published in 1933 by Li Weijian 李唯建, but the most influential poet in this genre is Feng Zhi 冯至, who published his Shisihang $j i$ 十四行集 (Collection of sonnets) in 1942. ${ }^{130}$ After being criticised as part of 'capitalist culture' in the Mao era, the Chinese sonnet revived in the 1980s with poets like Lin $\mathrm{Zi}$ 林子 and Tu An 屠岸, who published their collections of sonnets respectively in 1985 and 1986. ${ }^{131}$ In China, the 14-line poem is also popular among those known as 'campus poets'校园诗人, university student poets who like to write lyrics in this European form. Obviously, Yi Sha opposed this fashion and wrote this poem to mock it.

129 Yi Sha 伊沙. Esi shiren 饿死诗人 (Starve the poets). Beijing: Huaqiao chubanshe, 1994, p. 16.

${ }^{130}$ Li Zhimin 黎志敏. 'Zhongguo xinshi Zhong de shisihangshi' 中国新诗中的十四行诗 (The sonnet in Chinese new poetry). Waiguo wenxue yanjiu 外国文学研究 (Foreign literature studies), No. 1, 2000, p. 66. 131 Ibid. 
The 'reactionary' in the title also denotes the rebellious character of the poem, a subversive usage of Chinese communist jargon. 'Reactionary', a serious accusation in the communist discourse, becomes the creative source of this poem as a challenge to the established norm. Yi Sha begins the poem with a sarcastic tone as 'suddenly something sour in me is about to pour out' and 'more urgent than diarrhoea'. His sarcastic tone continues as he compares 'the 14-line poem' to an exquisite, good-sized bedpan. He parodies those poets who have 'more snot than tears' and are obsessed with worn-out images like 'girls', 'flowers', 'death' and 'unrecognizable gods'. His biting humour appears as the 'I' tries to give the poem a perfect ending but 'too much / I extend this 14-line poem to the 15th line'. The poem is 'reactionary' in both form and content.

In 'Lao huli' 老狐狸 (The old fox), Yi Sha's playfulness is fully exhibited as he almost turns the poem into a joke:

\section{The Old Fox}

(Instruction: Anyone who wants to read this poem please apply developer to the 'blank' place once or twice, then 'The Old Fox' will show its true colours.)

\section{老狐狸}


（说明：欲读本诗的朋友请备好显影液在以上“空白”之处涂抹一至两遍《老 狐狸》即可原形毕露。) 132

The "old fox" will show its true colours' in the instruction has a dual meaning: it literally refers to the poem entitled 'The old fox'-apply developer to the blankness and the reader will see this poem. However, the poem will not appear if they do so. Then the 'old fox' turns out to be the author himself who 'shows its true colours', for it is an open hoax and the reader who follows his instruction will not see anything. As Yi Sha himself explains, originally he did not write anything under the title but later found that it looked 'artificial' 人造的痕迹太重. Then he added the instruction. ${ }^{133}$ This change enriches the playfulness of the poem and makes it a representative of Yi Sha's 'playful' poems.

\section{Political Incorrectness}

Both the profanity and playfulness of Yi Sha's poetry can be put under the broader label of 'political incorrectness'. According to Geoffrey Hughes, 'political correctness' became part of the modern lexicon and part of the modern mind-set as a result of the wide-ranging public debate which started on campuses in the United States from the late 1980s on. ${ }^{134}$ It is difficult to give a comprehensive definition of the term but it is said to inculcate a 'sense of obligation or conformity in areas which should be (or are) matters of choice' and it 'has had a major influence on what is regarded as "acceptable" or "appropriate" in language, ideas, behavioural norms and values' ${ }^{135}$ Semantically, it was first coined by Mao Zedong in the 1930s as 'a policy concept denoting the orthodox party line of Chinese Communism'. Then it was borrowed by the American New Left

\footnotetext{
132 Ibid, p. 102.

133 Yi Sha 伊沙. 'Zishang zixi (1988-1992)' 自赏自析（1988-1992） (Self-appreciation and self-analysis: 19881992). In Yi Sha 伊沙, Zhongguo xiandai shilun 中国现代诗论 (On modern Chinese poetry), Taipei: Showwe Information, 2011, p. 192.

${ }^{134}$ Geoffrey Hughes. Political Correctness: A History of Semantics and Culture. Malden, MA: Wiley-Blackwell, 2010, p. 3.

135 Ibid, p. 4.
} 
in the 1960 s with 'a more rhetorical than strictly programmatic sense'. It is 'essentially a modern coinage by a minority, deriving from politically correct, dating from about $1970, .136$

Yi Sha's poetry is generally a challenge to this 'obligation' or 'conformity', a violation of the established norm, and thus it can be considered 'politically incorrect'. The political incorrectness of Yi Sha's poetry includes elements on two levels - there is not only in his incorrectness on the grand level, like his profanity to cultural icons, sarcasm directed at political authorities, mockery of romantic lyricism, insistence on his unofficial stance, attacks on literary elitism, deconstruction of poetic loftiness, and rebellion against the mainstream aesthetics. But there is also his incorrectness on the identity/gender/personal level, like his use of swear words, obsession with taboo themes, body writing, male chauvinism, and sexism. On both levels, Yi Sha behaves like an iconoclast, fearlessly offending against any form of political correctness, which makes Yi Sha both a controversial figure and a powerful poet. Below is a poem by Yi Sha on the September 11 attacks:

\section{9/11 Psychological Report}

First second: open-minded in shock

Second second: dumb as a wooden chicken

Third second: half-disbelieving

Fourth second: convinced and undoubting

Fifth second: passively watching from afar

Sixth second: taking joy in others' misfortune

Seventh second: talking of revenge

Eighth second: worshiping outlaws

Ninth second: astounded by faith

${ }^{136}$ Ibid, pp. 17-18. 
Tenth second: suddenly remembered

my younger sister

lives in New York

I hurry to make

a long-distance phone call

it doesn't connect

I rush to the computer

go online

and send an email

as I type

my fingers shake

'Sister, sister,

are you still alive?

Your older brother is worried to death! ${ }^{137}$

\subsection{1 心理报告}

第 1 秒钟目瞪口呆

第 2 秒钟呆若木鸡

第 3 秒钟将信将疑

第 4 秒钟确信无疑

第 5 秒钟隔岸观火

第 6 秒钟幸灾乐祸

第 7 秒钟口称复仇

第 8 秒钟崇拜歹徒

第 9 秒钟感叹信仰

第 10 秒钟猛然记起

我的胞妹

137 Yi Sha. '9/11 Psychological Report', trans. Heather Inwood. Chinese Literature Today, Vol. 2, No. 2, 2012, p. 13. 


\author{
就住在纽约 \\ 急拨电话 \\ 要国际长途 \\ 未通 \\ 扑向电脑 \\ 上网 \\ 发伊妹儿 \\ 敲字 \\ 手指发抖 \\ “妹子，妹子 \\ 你还活着吗? \\ 老哥快要急死了!” 138
}

In this poem, Yi Sha vividly depicts the 'politically incorrect' reactions of an ordinary Chinese to the astonishing catastrophe in New York City in 2001. The protagonist's reactions include three stages. From the first to the fourth second, his reaction is 'being shocked', not believing such a disaster has really happened, until he is finally convinced of the truthfulness of the news. The second stage, from the fifth to the ninth second, contains some 'politically incorrect' depictions. His reaction changes from indifference (passively watching from afar) to feeling happy (taking joy in others' misfortune). In the next few seconds, he even considers the attack a good deed (talking of revenge) and feels admiration for the terrorists (worshiping outlaws). His admiration comes to a culmination in the ninth second as he sees the attack as a case to show the power of faith (astounded by faith).

These 'politically incorrect' depictions, though insulting to the $9 / 11$ survivors, are largely the true reactions of an ordinary Chinese person to the catastrophe in the US. Historically, the relationship between China and the US has been generally stable

138 Yi Sha 伊沙. ‘9.11 xinli baogao' 9.11 心理报告 (9/11 psychological report). Chinese Literature Today, Vol. 2, No. 2, 2012, p. 13. 
except for some open conflicts such as the Korean War and the Vietnam War. However, in Chinese official propaganda, the US is persistently portrayed more as an 'enemy' than as a 'friend', and Chinese mainstream media keep describing the hegemony of the US as the major threat to world peace. Under such influences, it is understandable that an ordinary Chinese would feel somewhat joyful when hearing about the disaster and would see the terrorist attack as a sort of heroism.

However, in the third stage (from the tenth second to the ending), Yi Sha artfully changes the identity of the protagonist from a bystander to one connected to the catastrophe, when he 'suddenly remembered / my younger sister / lives in New York'. This change of the protagonist's identity leads to the dramatic change in his attitude towards the catastrophe - in sharp contrast, to the truthful representation of an ordinary Chinese faced with the news of the $9 / 11$ attacks - and thus gives this poem a deeper meaning than the Cold War mentality.

One of Yi Sha's best-known poems, 'Jiejiebaba' 结结巴巴 (St-stammering, ststuttering), is an excellent instance of his playfulness in language, yet from a sociological perspective, it is a playfulness that borders on being politically incorrect. The poem reads as follows:

\section{St-stammering, St-stuttering}

I st-stammer, st-stutter

S-s-second-class disability

Can't control my r-r-rushing thoughts

Nor my legs

Saliva f-f-flying in all directions

You all smell so old and stale

M-m-my poor lungs 
How hard they have to slave!

I have to g-g-get away from this

Your st-st-strange

Rhythms

I can hardly wait to break free

M-m-my

Machine-gun-like language

F-f-fires in bursts

Full of pleasure

St-stammering, st-stuttering, my fate

But there are n-n-no ghosts in my way

L-1-look at me, I say

There's only indifference on my face ${ }^{139}$

\section{结结巴巴}

\section{结结巴巴我的嘴}

\section{二二二等残废}

咬不住我狂狂狂奔的思维

还有我的腿

你们四处流流流淌的口水

散着霉味

我我我的肺

多么劳累

139 Yi Sha. Starve the Poets! Trans. Simon Patton and Tao Naikan. Northumberland: Bloodaxe Books, 2008, p. 33. 
我要突突突围

你们莫莫莫名其妙

的节奏

急待突围

我我我的

我的机枪点点点射般

的语言

充满快慰

结结巴巴我的命

我的命里没没没有鬼

你们瞧燋瞧我

一脸无所谓 140

The poem, written in 1991, is generally considered as a most effective deconstruction of the poetic language by imitating the way a stutterer speaks. On the one hand, Yi Sha's introduction of a stutterer's manner of speech enlarges the vocabulary and therefore the repertoire of contemporary Chinese poetry. On the other hand, it also insists on the minjian aesthetics of the earthly and the everyday.

Maghiel van Crevel considers it a model of Yi Sha's 'rejective poetry'. ${ }^{141}$ Based on his theory of the Elevated and the Earthly, van Crevel further notes that another dichotomy that can be applied to contemporary Chinese poetry is receptive vs. rejective. As a poetic feature, rejectiveness can be in evidence not only in an aggressive pace and tone of

\footnotetext{
140 Yi Sha 伊沙. Esi shiren 饿死诗人 (Starve the poets). Beijing: Huaqiao chubanshe, 1994, p. 1.

141 Maghiel van Crevel. 'Rejective Poetry? Sound and Sense in Yi Sha.' In Maghiel van Crevel, Tian Yuan Tan, and Michel Hockx, eds. Text, Performance, and Gender in Chinese Literature and Music: Essay in Honor of Wilt Idema. Leiden and Boston: Brill, 2009, p. 389.
} 
voice, deconstructive rhyme schemes, short lines and interrupted enjambement, but also in attitudes such as cynicism, disbelief, negation and demystification. ${ }^{142}$ According to van Crevel, Hai Zi's work is an example of receptive poetry, while Yi Sha's work is representative of rejective poetry. In van Crevel's article, 'St-stammering, st-stuttering' is an example of rejective poetry in both sound and sense.

By imitating the broken language of a stutterer, Yi Sha depicts a rebellious self-image of a flawed hero or anti-hero who cannot speak well and is thus with 's-s-second-class disability'. However, this figure has 'r-r-rushing thoughts' and legs that he himself cannot control. He wants to break through to the surrounding people with 'saliva f-fflying in all directions' and find his own way to speak, namely, the 'machine-gun-like language' full of pleasure. Yi Sha is here making a manifesto of his artistic view of Colloquial Poetry. Opposed to the soft, pretty language of traditional lyricism, he claims his language is 'machine-gun-like', a language coming from life and reality, full of energy and strength. This simile suddenly gives a positive meaning to the broken language and makes it a powerful poetic language. In the last stanza, Yi Sha's cynical tone appears as he says there is 'only indifference on my face'. Nevertheless, this statement can also be regarded as an expression of his insistence on his own style of language, regardless of the comments of others. Though the fate of his art is 'ststammering, st-stuttering', there are 'n-n-no ghosts'. 'St-stammering, st-stuttering' is to some extent a manifesto of Yi Sha's poetics told in a playful and politically incorrect way.

Yi Sha's political incorrectness, although irritating or offensive to some, can be an endearing feature of his poetry. In his poetry, he keeps challenging, deconstructing, playing, stimulating, and breaking rules, unafraid to offend anyone in both official and unofficial contexts. Unflinching and brutally honest, his poetry never flatters anyone, including himself. To some extent, this is the ultimate representation of minjian. He

142 Ibid, pp. 389-90. 
writes an 'incorrect' poetry which is not beautiful but powerful.

\section{Poetry of Facts: From 'Pre-Colloquial' to 'Post-Colloquial'}

Yi Sha, though himself not a keen theorist, also contributes to the theorization of Colloquial Poetry. Although he seldom writes theoretical articles to elaborate his ideas, a few terms coined by him have become widespread, and are frequently cited by other poets in their discussions of Colloquial Poetry. His terms and concepts sporadically appear in his conversations with his fellow poets and then gradually become known to the outside world. In a nutshell, they are well-accepted only by poets within his circle rather than universally acknowledged terms.

In the circle of Yi Sha and his fellow Minjian Poets, there exists a whole set of poetic terminology not necessarily the same as that widely accepted by the outside academia. In other words, they use a set of poetic terms which make sense only in their own exclusive discourse, which is rather an enclosed system. For example, Xu Jiang, Yi Sha's Beijing Normal University alumnus and fellow Minjian Poet, once distinguished 'modern poetry' 现代诗 from 'new poetry' 新诗. ${ }^{143} \mathrm{He}$ used five standards to judge whether a poem belongs to 'modern poetry', and, in particular, he excluded all the poetry before 1949, including poetry by those influenced by Western modernism such as Dai Wangshu 戴望舒 and Li Jinfa 李金发, from his category of 'modern poetry'. ${ }^{144}$

143 In 1991, Xu Jiang started editing an unofficial magazine Kui 葵 (Sunflower) in Tianjin; the name of the magazine comes from Allen Ginsberg's poem 'Sunflower Sutra'. His concept of 'modern poetry' is included in a series of articles published in Sunflower. See Wang Shiqiang 王士强. 'Kui: “xiandai shi” de tuizhu zhe yu jisan di' 《葵》: “现代诗”的推助者与集散地 (Sunflower: a booster and distribution centre of “modern poetry'). Lingnan shifan xueyuan xuebao 岭南师范学院学报 (Journal of Lingnan Normal University), Aug. 2017, Vol. 38, No. 4, p. 56.

144 Xu Jiang's five standards for modern poetry include: 1. An intellectual worldview. 2. A specific and conscious direction of language construction. 3. The ability to rationalise such characteristics as 'lyricism', 'irony' and 'humour' in poetry. 4. Regarding simplicity as the main goal in the pursuit of poetry. 5. Keeping such elements as 'humanity', 'philosophical ideas' and 'emotions', which are regarded as the highest goals in traditional poetry, in the strict control of the poetic requirements such as simplicity, implicitness and conciseness. See Xu Jiang 徐江. “'Xiandai shi” yu 
Another example is that the Colloquial Poets have created a category of 'Image Poetry' 意象诗, as opposed to their own 'Colloquial Poetry'. For them, 'Image Poetry’ refers to poetry with complicated syntax and images, such as the works of Tomas Tranströmer, rather than to the poetry of well-known imagists, like Ezra Pound. Two points need to be noted here: 1 . Most of these terms, like 'Image Poetry' and 'Colloquial Poetry', have existed and have been used in their circle for a long time but their origins are unknown. 2. These poetic terms and concepts do not constitute an organic theoretical system, but are rather an assemblage of different names coined by different poets, with their meanings varying from person to person. Other poets do not necessarily agree with $\mathrm{Xu}$ Jiang's concept of 'modern poetry' and vice versa. Though these terms and concepts have not been widely accepted by people outside their circle, this phenomenon still shows the Minjian poets' efforts to create a theoretical system of their own.

Yi Sha's major contribution to the theorization of Colloquial Poetry lies in his differentiation between qian kouyu 前口语 (Pre-Colloquial) and hou kouyu 后口语 (Post-Colloquial). According to Yi Sha, 'pre-' refers to the Colloquial Poetry in the 1980s, including Yu Jian, Han Dong and other poets, while 'post-' is the poetry in the 1990s, from Yi Sha and his fellow poets onwards. ${ }^{145}$ According to Yi Sha and his fellow poets, the watershed between 'pre-Colloquial' 前口语 and 'post-Colloquial' poetry 后口语 is Yi Sha himself. Though Yi Sha's differentiation can be regarded as self-serving, it does reflect a new understanding of Colloquial Poetry. It is obvious that Yi Sha's poetry is more than mere colloquialization in language, as he writes:

Colloquial poetry is not the same as the colloquialization on the language levelthat is to say, 'colloquialization' is not equal to 'Colloquial poetry'. Seen from a poet's angle, Colloquial Poetry is a brand-new poetic thinking: one that breaks

\footnotetext{
“Xinshi” jiujing you he qubie? ’ “现代诗”与 “新诗” 究竟有何区别？ (What is the real difference between 'modern poetry' and 'new poetry'?), http://book.ifeng.com/a/20150617/15821 0.shtml\#, accessed 27 April 2019. 145 Yi Sha, Interviewed by Liang Yujing, 2016, see Appendix.
} 
loose from the original thinking of 'having something to say' - a poet's thinking, and it will create a poetic structure. If 'Pre-Colloquial' is still some words to say, then 'Post-Colloquial' has a more obvious structure, usually constituted by some fragments of incidents ...

口语诗并不等于在语言层面的单一口语化一一也就是说: “口语化”并不等于 “口语诗”。从诗人的角度来说，口语诗等于一种全新的诗歌思维：是一种摆 脱公式的“有话要说”的原始思维——诗人的思维, 将创造出诗歌的结构, 如 果说“前口语”还只是一些想说的话, 那么“后口语”便有了更加明显的结构, 通常是由一些事件的片段构成...... ${ }^{146}$

This quotation is from 'Kouyu shi lunyu' 口语诗论语 (The Analects of Colloquial Poetry), Yi Sha's only theoretical work on Colloquial Poetry. In fact, it can hardly be strictly called theoretical, as it consists entirely of dozens of fragmental remarks by Yi Sha, written in the vein of Confucius's Lunyu 论语 (The Analects). Some terms in this piece has been frequently used among a certain group of poets, but they are not yet widely accepted, such as 'Pre-' and 'Post-' Colloquial Poetry. In the quote above, Yi Sha centres his understanding of Colloquial Poetry around the word 'structure', that is, Colloquial Poetry is a poetic system rather than mere colloquialism in language.

In Yi Sha's eyes, the 'Pre-Colloquial' poets still want to 'make' a poem, thus 'having something to say', in which the poem is the something made out by the poet, who still presents himself in the poem. In contrast, 'Post-Colloquial' poetry has a structure of its own and thus can present itself without the intervention of the poet. In other words, the 'post-' poems are a mature poetry composed of facts that can show themselves rather than through the interpretation of the poet. Yi Sha thinks the early Colloquial Poets wrote this kind of poetry spontaneously, without the self-consciousness that it is a new type of poetry. Instead, they saw it as a mere inclination to be 'colloquial' in language.

146 Yi Sha 伊沙. 'Kouyushi lunyu' 口语诗论语 (Analects of Colloquial Poetry). Shichao 诗潮 (Poetic tide), No. 2, 2015, p. 121. 
According to Yi Sha:

The 'Pre-Colloquial' poets like to say: I am not a Colloquial Poet but a Chinese Language poet — this affiliation with grandeur conceals their unconsciousness.

“前口语”诗人喜欢说: 我不是口语诗人, 而是汉语诗人一一好大喜功的表面 下深藏着他们的非自觉。147

Though it is still arguable whether Yi Sha's 'Post-Colloquial' poetry manifests a mature, systematic poetics, it is certain that it indeed has gone beyond the stage of mere colloquialism and at least bears some characteristics of a new poetics with its own intrinsic devices.

For Yi Sha, the one key notion that distinguishes 'Post-Colloquial' from 'Pre-Colloquial' poetry is that the former contains shishi de shiyi 事实的诗意 (poetry of facts). This notion accentuates Yi Sha's poetics. Yi Sha has never given a theoretical explanation about 'poetry of facts' but this term is one of the most frequently mentioned phrases in his remarks about poetry, or when he comments on other poets' works on social media such as Weibo and Wechat. One important comment comes from his 'Analects of Colloquial Poetry', his only theoretical work on poetics. After stating that 'PostColloquial' has a more obvious 'structure', constituted by 'fragments of incidents', Yi Sha says:

Therefore, in a Colloquial Poet's work, he writes about 'incident after incident', an 'incident maker' - I think they are not satire or ridicule but remarks that reveal the 'poetry of facts' characteristic.

所以, 口语诗人写起诗来“事儿事儿的”“很事儿逼”148_—在我看来这不是讽

147 Ibid, p. 121.

148 The phrase shi'erbi 事儿逼 comes from Beijing dialect. It means 'a troublemaker', but Yi Sha uses it creatively 
刺和调㑆，而是说出其“事实的诗意”的最大特征。149

Yi Sha considers all the Colloquial Poets before him as 'Pre-Colloquial' poets, whose poetry was written in colloquial language but that lacks a 'poetic structure'. Thus, the most distinctive feature of the 'Pre-Colloquial' poetry is colloquialization on the language level. However, Yi Sha thinks this mere 'colloquialization' is spontaneous rather than deliberate. The Pre-Colloquial Poets, though they use colloquial language to write poetry, still intend to interrupt their narration with a traditional way of expression, that is, 'having something to say'. By contrast, the Post-Colloquial Poets focus on the incidents per se, instead of their re-presentation or their ramifications. They present the incidents themselves while withholding any judgement, for the facts speak for themselves. This is the essence of the 'poetry of facts' for Yi Sha.

In my interview with Yi Sha, when I asked him what 'poetry of facts' actually is, he gave a detailed explanation:

This is what I call 'a fact': there must be a fact before poetry happens. The 'poetry of facts' I emphasize is, you have to make me see the fact before seeing the poetry growing out of the fact. That's just what I mean ... because the fact you talk about has produced poetry itself. Or the person, the object you write about-it has produced poetry itself. Then your language is to reproduce this 'poetry of facts' and your language is not created out of nothing. ${ }^{150}$

这就是我说的“事实”，诗意的存在一定是先有一个事实。我强调的这个诗歌 中的“事实的诗意”，指的就是，你要让我先看到这个事实，然后再见到这个

\footnotetext{
and metaphorically to highlight the focus of the Colloquial Poets on factual presentation in poetry. In this phrase, the character shi 事 alone can refer to an incident. Similarly, shi'ershi'erde 事儿事儿的, also a phrase from Beijing dialect, refers to a troublesome person. Hereby Yi Sha places an emphasis on the prominence of narrative stories and incidents in Colloquial poetry.

149 Yi Sha 伊沙. 'Kouyushi lunyu' 口语诗论语 (Analects of Colloquial Poetry). Shichao 诗潮 (Poetic tide), No. 2, 2015, p. 121.

150 Yi Sha, Interviewed by Liang Yujing, 2016, see Appendix.
} 


\section{事实所绽放出的诗意, 这就是我的意思.......因为你讲的这个事, 它本身已经 构成诗意了。或者你讲的这个人, 讲的这个物, 本身已经构成了诗意。那么 你的语言就是把这个 “事实的诗意” 再现出来, 语言不是凭空造的了。}

Yi Sha's explanation of 'poetry of facts' shows his consistent view on aesthetics-he, opposed to the fancy style of rhetoric, embraces a down-to-earth poetics. To him, poetry comes out of facts rather than rhetoric; that is to say, what to write about is more important than how to write and the former determines whether a poem should be. From Yi Sha's perspective, in some poems, there is no poetry at all in the 'facts'; a specious poetry is produced completely through the poet's rhetorical techniques such as parallelism, metaphor and imagery. Therefore, he coined this term as a demarcation to distinguish the 'real' poetry from the 'fake' one. This standard is also a demonstration of Yi Sha's own poetics, as he persistently keeps conventional rhetoric to a minimum in his poetry by using plain and colloquial language to present the most basic and yet the most meaningful poetic 'facts'.

Though Yi Sha use the word shishi (fact) in this term, it should be noted that this word is inaccurate and can be misleading, especially when we examine it from a theoretical angle. There is no pure fact in literature. Facts become poetry through language and the poet's use of it. In the opening chapter of Literary Theory: An Introduction, Terry Eagleton points out that a distinction between 'fact' and 'fiction' is often a questionable one. ${ }^{151}$ In literature, it is difficult to distinguish what is factual from what is fictional. In a sense, everything in a poem is created by the poet and thus can hardly be a 'fact'. In The Limits of Realism: Chinese Fiction in the Revolutionary Period, Marston Anderson studies the connotations the term 'realism' accumulated from the beginning of the twentieth century to the late 1930s, and finds this European theory of imitating the objective reality encountered either moral or social impediments in Chinese fiction. For example, according to Anderson, in Lu Xun's 鲁迅 short stories, 'the same moral

151 Terry Eagleton. Literary Theory: An Introduction. Carlton: Blackwell Publishing, 2008, p. 1. 
purpose that dictated the didactic element in his fiction [...] at the same time compelled a reflexive examination of his own role as observer of Chinese society'. ${ }^{152}$ Zhang Tianyi 张天翼 calls realism into question while 'continuing to employ the suspect conventions to structure and pattern his story' ${ }^{153}$ Both Eagleton's statement and Anderson's study suggest that 'poetry of facts' is a questionable or misleading term, at least literally.

What Yi Sha refers to by 'facts' is the key to understanding this term. In my view, rather than an attempt to imitate the objective reality, Yi Sha uses this word to refer to the material he selects to make poetry, namely, the outcome of the process in which he distinguishes the poetic material from the unpoetic one. This is a process that involves perspectives and value-judgement. In 'poetry of facts', Yi Sha is similar to Ezra Pound, who outlined three principles in 1912 for the Imagists, the first point being 'direct treatment of the "thing" whether subjective or objective'. ${ }^{154}$ In 1913, Pound further suggested, 'Use no superfluous word, no adjective, which does not reveal something'. ${ }^{155}$ Pound's 'direct treatment of the "thing" is well illustrated by his famous two-line poem 'In a Station of the Metro':

The apparition of these faces in the crowd:

Petals on a wet, black bough. ${ }^{156}$

Though Pound and Yi Sha are similar in their attitudes toward the poetic language, attempting to present the objects instead of describing them with excessive rhetoric, their difference is also apparent. What Pound focuses on is imagery and how to create

\footnotetext{
152 Marston Anderson. The Limits of Realism: Chinese Fiction in the Revolutionary Period. Berkeley, CA: University of California Press, 1990, p. 77.

153 Ibid, p. 160.

154 Ezra Pound. ‘A Retrospect'. Poetry Foundation's website: https://www.poetryfoundation.org/articles/69409/aretrospect-and-a-few-donts, accessed 3 August 2020.

155 Ezra Pound. ‘A Few Don’ts'. Poetry Foundation's website: https://www.poetryfoundation.org/articles/69409/aretrospect-and-a-few-donts, accessed 3 August 2020.

156 Ezra pound. 'In a Station of the Metro'. Poetry Foundation's website: https://www.poetryfoundation.org/poetrymagazine/poems/12675/in-a-station-of-the-metro, accessed 3 August 2020.
} 
strong, evocative images, whereas Yi Sha often tries to produce dramatic effects in his narrative short poems, such as the pissing on the Yellow River in 'Crossing the Yellow River' and the sudden change in the protagonist's attitude in '9/11 Psychological Report'. Yi Sha's 'poetry of facts' is therefore a dramatic poetics, and a large part of his short poems read like mini-plays. Yi Sha is very adept at finding dramatic material from daily life, which constitutes his 'facts'. With this dramatic material, he can present it in a pared-down, colloquial language without much rhetoric. The drama in the facts itself becomes poetry.

Another term coined by Yi Sha, also deriving from 'poetry of facts' is jiwu 及物, which, in Yi Sha's poetics, means 'a word which is able to reach an object', and is also a demonstration of his style of using plain language. In classical Chinese poetry, there was yongwu ci 咏物词, which became popular and important during the late Song. According to Zong-qi Cai, broadly speaking, the term yongwu ci refers to 'a song lyric that depicts an object'. ${ }^{157} \mathrm{Wu}$ 物 is the term 'for anything that can be apprehended or perceived by the $x i n$ (mind)'. ${ }^{158}$ Thus, $w u$ connotes 'all concrete entities and phenomena in the material world and in human affairs, as well as abstract ideas and unreal and imaginary things.' ${ }^{159}$ However, in a narrow sense, $w u$ often refers to 'small objects in nature', such as flowers and birds. ${ }^{160}$ Different from traditional yongwu, Yi Sha's jiwu is not the relationship between the mind and the object, but that between the word and the object. What Yi Sha emphasises is that a word must be the representation of a specific object instead of beautiful nonsense.

By the term jiwu, Yi Sha particularly disapproves of the use of the pompous, superficially poetic lexicon in poetry and insists that the poet must find and articulate a direct connection between the word and the object, between the signifier and the

\footnotetext{
157 Cai, Zong-qi, ed. How to Read Chinese Poetry: A Guided Anthology. New York: Columbia University Press, 2007, p. 287.

158 Ibid.

159 Ibid.

160 Ibid.
} 
signified. Yi Sha objects to the phenomenon that some poets tend to use ambiguous words in poetry to create yijing 意境, which can be roughly understood as 'poetic atmosphere'. An example is Zhang Zao's 张來 famous line 'Wo tiantian mengjian wanguchou' 我天天梦见万古愁 (Every day I dream of the worries of ten thousand years). ${ }^{161}$ Judging by Yi Sha's standards, the wanguchou (worries of ten thousand years), a word with immense classical poetic beauty, is not a jiwu word. To Yi Sha, this 'poetic atmosphere' is largely created by a set of classical clichés, without definite signified objects. There is nothing but emptiness behind such a labyrinth of rhetoric. Such poetry largely comes from the poets' words rather than the facts and there is not a solid foundation under their words. Yi Sha's emphasis on jiwu does not mean that he opposes using puns in poetry, for even if there is a pun, its two meanings are still definite. The term jiwu embodies Yi Sha's negative attitude towards empty rhetoric by emphasizing that a poet's words must have a solid connection with the objects they refer to.

Both 'poetry of facts' and jiwu show Yi Sha's essential notion that poetry should lie in the facts a poet writes about rather than on the lexicon level. Thus, in his own poetry, he keeps his rhetoric to a minimum and tries hard to present concrete 'objects' in his poems. As a result, it is very clear why Yi Sha prefers the narrative poem instead of the lyrical: for the narrative poem is a more suitable form for him to use 'objects' or 'events' as a direct representation of ideas. Most of his poems centre on an incident, a fact or a dramatic scene, rather than a feeling. His poetry is anti-lyrical, full of dramatic narrations.

Yi Sha's advocacy for the narrative poem coincides with the general anti-lyrical trend of the Chinese avant-garde poetry in the 1990s. At the time, both the Minjian Poets and the Intellectual Poets turned to narration 叙事 in poetry and regarded narrative poetry

\footnotetext{
161 Zhang Zao 张杳. 'Gen Ciweitayewa de duihua' 跟茨维塔耶娃的对话 (In reply to Marina Tsvetaeva), https://www.douban.com/group/topic/72990797/, accessed 12 December 2019.
} 
as a revolt against the emotional lyricism in the 1980s. ${ }^{162}$ Sun Wenbo and Xi Chuan in particular proposed xushixing 叙事性 (narrativeness) in poetry. However, Yi Sha disapproves of the importance of narrative in poetry proposed by the Intellectual Poets and maintains that the Intellectual Poets' 'new discovery' of narrative has been a common feature of Colloquial poetry since the 1980s. ${ }^{163}$ Moreover, Yi Sha insists on using the term xushu 叙述 (narration) rather than xushi 叙事 (narrative) to refer to this feature in contemporary poetry. His choice of naming the feature also shows his preference for the everyday language rather than academic jargon. According to Zhao Yiheng 赵毅衡, xushu and xushi have been interchangeably used by Chinese scholars for a long time. Scholars like Shen Dan 申丹 and Wang Liya 王丽亚 insist that xushu refers to the technique of narration, whereas xushi refers to both the structure of the story and the technique of narration. However, Zhao Yiheng disagrees with them by claiming there is no clear distinction between structure and technique. ${ }^{164}$ Generally, though the two words are sometimes interchangeable, xushu is a common word in everyday language, while $x u s h i$ is a word primarily used in literary criticism. Therefore, it is understandable that Yi Sha prefers xushu to xushi.

In a short poem written in 2016 about his visit to South Korea, Yi Sha gives an illustration of the notion by using 'Poetry of facts' as its title:

\section{Poetry of Facts}

The 38th parallel north

is not a line

\footnotetext{
162 See Luo Zhenya 罗振亚. “Jiushi niandai xianfeng shige de “xushi shixue” 九十年代先锋诗歌的“叙事诗 学”('Narrative poetics' of the avant-garde poetry in the 1990s). Wenxue pinglun 文学评论 (Literary review), No. 2, 2003, pp. 88-93.

163 Yi Sha, Interviewed by Liang Yujing, 2016, see Appendix.

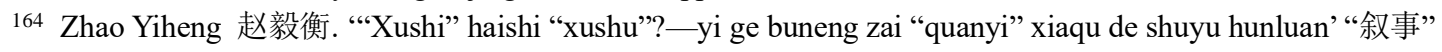
还是“叙述”? ———不能再“权宜”下去的术语混乱 (“Narrative’ or “narration”?: a terminology confusion that can no longer be 'expedient'). Waiguo wenxue pinglun 外国文学评论 (Foreign literature review), No. 2, 2009, p. 229 .
} 
but 4 kilometres wide,

a demilitarised zone

delimited by North and South Korea.

After 60 years,

it has become

the most successful animal sanctuary in the world.

\section{事实的诗意}

三八线

不是一条线

它有 4 公里宽

南北朝鲜划定的

非军事区

60 年过去了

成为世界上

最成功的动物保护区

This poem is a good example to show Yi Sha's 'poetry of facts'. There is no complex imagery or metaphors. Only narration of facts. All the traditional rhetoric is kept to a minimum. All the poetry comes from the facts being presented and amounts to a biting sarcasm - the war zone turns out to be the 'most successful animal sanctuary' —an unexpected fact.

In another poem 'Hailing a taxi' 打车, the dramatic effects created by facts are extremely intense:

\section{Hailing a Taxi}

Nanning. 
A spring night in January.

Nice flowers under a full moon.

I jumped

out of the flowering shrubs

to the roadside,

hailing a taxi.

I waved my hand

at a speeding cab

that came near.

It slowed down,

looked at me awhile

with doubt and surprise,

then hit the gas

and speeded up,

running away.

Only then

did I realize

from its back

it was a

police car.

打车

南宁

一月的春夜

花好月圆

我自花从中

一跃而出

跳到马路边 
打车

冲着一辆

疾驰而来的出租车

招手

它慢下来

疑惑而又惊愕地

瞅我片刻

然后一踩油门

加快速度

继续前行

这时候

从其背影

我才看清

那是一辆

警车 ${ }^{165}$

In this poem, the poetry comes out in the last line- 'police car' - and the fact itself that the poet mistakes a police car for a taxicab. The fact constitutes the entire poetry without resorting to any rhetoric devices. The poem would fail if the cab remains a cab. Any cars other than a police car cannot produce such a dramatic effect, for a police car stands for authority and state power that usually keep people away, especially in China.

Chen Zhongyi considers 'poetry of facts' as an effective poetic idea of Yi Sha which has given rise to numerous good poems. However, he points out that the major problem of such poetry usually comes from its loose structure and tedious narration. As a result, a poem has to be saved by the last few lines presenting a strong 'fact'. Chen comments that 'poetry of facts is different from the lingering, blotting and circling in traditional poetry; usually it is a force that suddenly bursts forth at the last moment'. ${ }^{166}$ Though

165 Liang Yujing, ed. and trans. Zero Distance: New Poetry from China. Honolulu, HI: Tinfish Press, 2017, p. 124

166 Chen Zhongyi 陈仲义. 'Fei yixianghua de “shishi shiyi”” 非意象化的“事实诗意”('Poetry of facts' without 
Chen admits that Yi Sha has made great achievements with 'poetry of facts', his criticism is that Yi Sha writes too many poems and too hastily, which leads to his writing being filled with more facts than poetry. ${ }^{167}$ Nevertheless, Chen still thinks "poetry of facts' enriches the possibilities of the development of Chinese poetry, for it offers a new way to create poetry other than through traditional imagery. ${ }^{168}$ In my view, Chen's comments show the pros and cons of Yi Sha's 'poetry of facts' in poetry writing, but it must be recognized that it is a significant poetic idea for the Chinese minjian poetry to construct its own poetics and aesthetics.

To be sure, 'poetry of facts', as a notion, or an approach to poetry creation, cannot be regarded as a fully developed poetic system. No poet can base their writing on facts only. Even Yi Sha himself does not always follow this rule entirely. Poetry needs more elements beyond facts to work, if not all types of rhetorical devices. However, this notion serves as the foundation of Yi Sha's poetics, that not only influences his own writing but opens up a new path for other voices in contemporary Chinese poetry. When many poets were still infatuated with pompous rhetoric, Yi Sha encouraged them to shake off the burden of rhetoric and let the fact speak for itself.

To sum up, as an important element of the minjian movement, Colloquial Poetry started in the 1980s with the apparent feature of using colloquialism in poetry. However, it later went beyond the language level and became a full-fledged poetics whose characteristics are captured by van Crevel's notion of the Earthly. Yi Sha's Colloquial Poetry appeared in the early 1990s with an anti-lyrical manifesto and distinguished itself with its features like profanity, playfulness and political incorrectness. Yi Sha's major contribution to the theorization of Colloquial Poetry lies in his differentiation between 'Pre-Colloquial' and 'Post-Colloquial'. He invented the term 'poetry of facts' and made it a key notion of the 'Post-Colloquial' poetry, which brought the Colloquial poetics to a higher level,

imagery). Hongyan 红岩 (Red cliff), No. S2, 2011, p. 26.

167 Ibid, p. 27.

168 Ibid. p. 28. 
beyond colloquialism in language. The making of Colloquial Poetry is an essential component in the making of minjian, and Yi Sha serves as a key figure in this process. 


\section{Chapter Three Minjian in the Digital Age: Yi Sha's Poetry Activities}

In the previous chapter, I have discussed Yi Sha's Colloquial Poetry and how a colloquial poetics has come to shape and define minjian poetry. This chapter focuses on Yi Sha's poetry-related activities and his deliberate choice of an unofficial stance in opposition to China's official literary establishment. In the context of contemporary Chinese poetry, the word 'official' can be understood in both aesthetic and institutional terms. To be 'institutionally official', in the Chinese context, denotes a close connection between a poet and one or more official institutions. An official poet is usually a member of the Writers' Association, frequently attends official poetry conferences, and often has official awards bestowed upon them. Such activities are highly rewarding to a poet both financially and politically. Being institutionally official does not equate with being aesthetically 'official', however; the latter implies that a poet subscribes to the full set of state ideology and writes within state guidelines through a process of internalised self-censorship. It is difficult for an established Chinese poet to stay above the material and the less tangible allure of official affiliation. Yet, writing poetry that trumpets the official line is frowned upon. It is commonly believed that when a poet is considered aesthetically official, he must be a mediocre one, or worse, a mouthpiece of the state ideology. An avant-garde poet must remain aesthetically unofficial, because challenging or rejecting the official establishment is considered an inherent quality of avant-garde poetics.

Yi Sha is arguably one of the very few established Chinese poets who manages to remain both institutionally and aesthetically unofficial. Although he attends official conferences and occasionally receives official awards, Yi Sha's main literary activities exist outside the Chinese literary establishment, and he deliberately cultivates a distance between himself and the official poetry circles. Most importantly, indifference, rather than antagonism characterises his relationship to official institutions. He is not a 
dissident but a poet who runs his own business in the grey area, with the intention of finding his own poetic voice and style at a safe distance from official manipulation.

The following sections will discuss three major activities that have shaped and defined Yi Sha's reputation as a minjian poet: his contribution to the poetry website Poetry Jianghu, his establishment of the Chang'an Poetry Festival and the ambitiously named digital anthology 'New Poetry Classics'. The primary purpose of the discussion is to demonstrate how Yi Sha navigates the intricate passages between official and unofficial cultural spaces in contemporary China, and how age-old jianghu ethos and new-found digital savvy have joined forces in the making of a representative Minjian Poet. More broadly, these activities reflect the cultural habitat and behaviour patterns of the minjian poets as a group, as they struggle to survive outside of the officially sanctioned cultural mainstream. As an exemplary figure of the minjian group, Yi Sha not only puts his minjian principles into practice but also proves that poetry can survive and prosper without the patronage of China's official institutions.

\section{Poetry Jianghu: Performing the Unofficial in Digital Space}

The outburst of the Panfeng Polemic in 1999 coincided with the rapid development of the Internet in China and Chinese poets soon found their new space for producing poetry through the new technology. The first Chinese-language literary website is the America-based The Olive Tree 橄榄树, which was founded in 1995, a site that presents poetry, fiction and essays. ${ }^{169}$ According to scholarship to date on Internet literature in China, genre fiction and poetry are the two genres that have benefited from the wide usage of the Internet. While scholars like Jin Feng and Jing Chen give their attention to the social significance of Internet genre fiction, other scholars such as Michel Hockx,

\footnotetext{
169 Sang Ke 桑克. 'Hulianwang shidai de zhongwen shige' 互联网时代的中文诗歌 (Chinese-language poetry in the Internet age), 2001, http://www. poemlife.com/libshow-228.htm, accessed 16 September 2017.
} 
Michael Day and Heather Inwood concentrate on the production and consumption of Internet poetry. ${ }^{170}$ The two literary genres, though taking place in the same venue, are completely different in nature. As Michel Hockx describes, 'If genre fiction has been the most successful type of Chinese Internet literature in economic terms, poetry has outperformed all other modes of online writing in terms of variety, experimentation, and critical acclaim.' ${ }^{171}$ The rise of the Internet breathed new life into Chinese poetry in the first decade of the twenty-first century. According to Chen Zhongyi's research in 2016, about two million new poems are being produced annually on websites in China. ${ }^{172}$ Michael Day has agreed with Chen's estimate and has argued that there were over one hundred 'avant-garde' poetry websites in 2006 and 'several times that number of blogs by poets who contribute to these websites. ${ }^{173}$

In mainland China, the most influential poetry websites are Shi shenghuo 诗生活 (Poem life) and Poetry Jianghu. The former, founded in February 2000 by Sang Ke, Lai Er 莱耳 and others, is arguably the most comprehensive poetry website in China, showcasing poems and poetry-related news and essays. The latter, founded a month later after Poem Life by Nan Ren, is the gathering place of the Lower Body group, attracting avant-garde poets known or unknown to the general public, including Yi Sha, Shen Haobo and many others. After 2004, the Lower Body group became inactive as a poetry group but the website Poetry Jianghu was still online. In 2010, the website was

170 For further information, see: Jin Feng. Romancing the Internet: Producing and Consuming Chinese Web Romance. Leiden: Brill, 2014; Jing Chen. 'Refashioning Print Literature: Internet Literature in China'. Comparative Literature Studies, Vol. 49, No. 4, Special Issue: Modern China and the World: Literary Constructions, 2012, pp. 537-46; Michel Hockx. Internet Literature in China. New York: Columbia University Press, 2015; Michael Day. 'Online Avant-Garde Poetry in China Today'. In Christopher Lupke, ed. New Perspectives on Contemporary Chinese Poetry. New York: Palgrave MacMillan, 2008, pp. 201-17; Heather Inwood. Verse Going Viral: China's New Media Scenes. Seattle: University of Washington Press, 2014.

171 Hockx, Internet Literature in China, p. 141.

172 Chen Zhongyi 陈仲义. 'Xinshiji wunian wangluo shixiang guancha' 新世纪 5 年网络诗象观察 (Observations on internet poetry phenomena during the five years of the new century), 2006, http://www.poemlife.com/libshow-1596.htm, accessed 16 September 2017.

${ }^{173}$ Michael Day. 'Online Avant-Garde Poetry in China Today'. In Christopher Lupke, ed. New Perspectives on Contemporary Chinese Poetry. New York: Palgrave MacMillan, 2008, pp. 201-02. 
shut down by the government until Nan Ren, the original founder, revived it recently in 2017. Though all the poems are still online, the previous content of the poetry forum, including the discussions, debates and comments, are no longer available.

Both Day and Hockx consider Poem Life as one of the most important Chinese poetry websites. In 'Online Avant-Garde Poetry in China Today', Day outlines the development of the Chinese avant-garde poetry websites and calls Sang Ke, the cofounder of Poem Life, 'a key figure in the development of avant-garde poetry on the Internet in China'. ${ }^{174}$ Hockx employs Poem Life as an example and compares it with the English poetry websites Poetry Forum and Everypoet. Hockx discovers that the English websites represent the ethos of creative writing programmes with the purpose of 'merciless textual criticism', whereas the critique on Poem Life tends to be 'brief and friendly, or expressed in general terms ("like" or "dislike"), and is often interspersed with socialising comments'. ${ }^{175} \mathrm{He}$ also points out that, like many other unofficial poetry websites, Poem Life 'pays little if any attention to classical-style poetry' ${ }^{176}$

In contrast to their extensive discussion of Poem Life, Day and Hockx have paid little attention to Poetry Jianghu, despite the fact that it is the forerunner of many avantgarde poetry websites, such as Laji shige luntan 垃圾诗歌论坛 (Trash poetry forum) and Di shige luntan 低诗歌论坛 (Low poetry forum). ${ }^{177}$ A comparison between Poem Life and Poetry Jianghu is helpful to the understanding of unofficial Chinese poetry websites. A careful look at the two websites can give insight into their differences in stance: Poem Life is a gathering of poems and poetics by poets from different schools, a presentation of all aspects of Chinese poetry, while Poetry Jianghu is a collection of provocative works by radical poets, similar to an underground art show.

\footnotetext{
174 Ibid, p. 203.

175 Hockx, Internet Literature in China, p. 146.

176 Ibid, p. 148.

177 Laji shige luntan 垃圾诗歌论坛 (Trash poetry forum) was founded in 2004 and Di shige luntan 低诗歌论坛 (Low poetry forum) was founded in 2005. Both no longer exist.
} 
Much of their difference in standpoint is indicated in their respective names. 'Poem Life' is a general, eclectic term referring to poetry and life, poetry in life or a poetic life, also a pun on si shenghuo 私生活 (private life). 'Poetry Jianghu' contains the word jianghu, which conspicuously announces its unofficial positioning (江湖, literally rivers and lakes). In my view, the choice of jianghu as the name of the website is deliberate. It shows not only its distance from the official but also displays a heroic pose. Similar to the term minjian, jianghu does not have a single equivalent in English but rather a myriad of meanings and connotations.

The untranslatability of jianghu and minjian has been observed by critics, especially in the study of Chinese martial arts fiction and Chinese contemporary poetry. Maghiel van Crevel lists jianghu and minjian as two untranslatable words of special significance to the contemporary Chinese poetry scene. According to van Crevel, 'jianghu, literally "rivers and lakes", is an age-old, sentimental term for a world of wanderers and drifters living by their wits and their prowess, outside the realm of law and order: knights-errant, prostitutes, desperadoes, etc. Among other things, it signifies rebellion-with-a-grin from the margins of society against state institutions and elite traditions. ${ }^{, 178}$ Helena Yuen Wai, in her study of the term jianghu, maintains that the multi-layered connotations of the word include 'rivers and lakes' (literal), being carefree, a sense of freedom, a kind of longing for freedom and nature, a site of contestations, a fictional realm, a secret society as well as a human condition at large. ${ }^{179}$

In Yuen Wai's elaboration of jianghu's complex connotations, two basic meanings prove useful for the understanding of Poetry Jianghu as a cultural space. One is 'freedom'; the other is 'secret society'. Both of these meanings are embodied through the name 'poetry jianghu' as a symbol for the unofficialness of the minjian poets. As

\footnotetext{
178 Maghiel van Crevel. 'Walk on the Wild Side: Snapshots of the Chinese Poetry Scene'. MCLC Resource Centre, 2017. http://u.osu.edu/mclc/online-series/walk-on-the-wild-side/, accessed 9 September, 2019.

179 Helena Yuen Wai. "A Journey across Rivers and Lakes: A Look at the Untranslatable Jianghu in Chinese Culture and Literature" [online article], $452^{\circ} \mathrm{F}$. Electronic journal of theory of literature and comparative literature, 7, 2012, pp. 58-71, [Consulted on: 24/09/2017], http://www.452f.com/pdf/numero07/07_452f-mono-helena-yuen-wai-orgnl.pdf
} 
jianghu indicates a sense of freedom (from care, politics, officialdom, etc.), 'poetry jianghu' also bears such implications. However, what the Minjian Poets pursue is a spiritual freedom rather than a physical one, namely the freedom from the official Communist ideology and, more precisely, freedom from the prevailing, officially sanctioned aesthetics in poetry. In this sense, the name implies the creation of a space where the poets can be free in their aesthetic choices. Since this site is a space of jianghu, every poet partaking in it must be a jianghu ke 江湖客 (jianghu dweller). As Yuen Wai points out, jianghu 'is a text, a force and a site of resistance ... that oppose[s] all kinds of totalizing forces, ideological thoughts and institutionalizing power imposed by the authority, the hegemony, the hierarchy, and even by the language system itself'. ${ }^{180}$ In this sense, poets associated with the site must be aware of its unofficial stance and they must have joined to seek camaraderie in their quest for aesthetic freedom, despite or because of their institutional bondage.

The other meaning of jianghu, 'secret society', which sounds more radical and even anti-government, indicates that jianghu is a space of contestations, struggles, fights and outlaws. Interestingly, during the Panfeng Polemic, Xi Chuan, one of the major figures on the Intellectual side, condemned the Minjian Poets: 'In a nutshell, there is no such a thing as “minjian” standpoint. It is the standpoint of a “secret society” .’ 说到底“民间” 立场并不存在。与其说有个什么“民间立场”，还不如说有个“黑社会立场”181 Xi Chuan's point was to accuse the Minjian Poets of being driven by self-interest. In Xi Chuan's words, the first principle of the 'secret poetry society' standpoint is 'taking a share of the profit', thus the Panfeng Polemic, though a poetic debate on the surface, is in reality a conflict of interest, that is, the Minjian Poets intended to take a share of the profit. ${ }^{182} \mathrm{Xi}$ Chuan's accusation is reasonable but only up to a point. As I stated in the

\footnotetext{
180 Ibid, p. 65.

181 Xi Chuan 西川. 'Sikao bi manma geng zhongyao' 思考比谩骂更重要 (Thinking is more important than abuse). In Yang Ke 杨克, ed. 1999 Zhongguo xinshi nianjian 1999 中国新诗年鉴 (1999 yearbook of China's new poetry), Guangzhou: Guangzhou chubanshe, 2000, p. 540. 182 Ibid.
} 
first chapter, there is a duality in the minjian standpoint. During the Polemic, it was the strategy of the Minjian Poets to win the battle, while it was also a poetic ideal for the Minjian Poets to pursue. Xi Chuan's accusation points out the strategic characteristic of minjian and associates it with 'secret society'. This association reveals a connection between minjian and jianghu. Thus, it makes sense that the minjian poet dwells in poetry jianghu, a space of secret, sometimes illegal activities that is uncontrolled by officialdom.

It is worth noting that, though the name 'poetry jianghu' does indicate it is an unofficial poetry space or secret society, it does not necessarily mean the website is antiofficial, or the poets are dissidents. The difference between 'unofficial' and 'antiofficial' can be illustrated by Chen Pingyuan's explanation when he discusses the term jianghu in martial arts fiction. Chen describes the relationship between jianghu and miaotang 庙 堂 (temple, a term for the palace or officialdom) as:

\begin{abstract}
Although Jianghu is far from the 'temple' (palace), it is not opposed to the temple (as is 'Lulin'). Neither going from 'Jianghu' to 'success in the temple' nor from the 'temple' to 'failure in Jianghu' is so unbearable. The former is a story of 'rising to power' $[\ldots]$, while the latter is perhaps about 'heroes falling into difficulty' $[\ldots] \cdot{ }^{183}$
\end{abstract}

The relationship among miaotang, jianghu and Lulin is a good reference point for the understanding of minjian and jianghu in the context of contemporary Chinese poetry. Compared with Lulin 绿林 (dissidents), jianghu has a more subtle relationship with miaotang. Unlike Lulin which is the opposite, the antagonist and the enemy of the authorities, jianghu, though with a strong implication of unofficialness, is more like a space for people to enjoy freedom from the control of the government, a grey area the government tends to make use of rather than eliminate. People in jianghu do not see the

183 Chen, Pingyuan. The Development of Chinese Martial Arts Fiction: A History of Wuxia Literature, trans. Victor Petersen. Cambridge: Cambridge University Press, 2016, p. 160. 
officials as their enemies; they can be friends as long as the officials do not violate the jianghu rules. The jianghu people, though unofficial, are not necessarily dissidents. Similar situations can also be found in poetry jianghu. Those poets do not oppose official publications or prizes. They are happy to be published in official magazines and given official awards. However, if this violates the jianghu rules (for example, the poet has to write aesthetically official poems to keep in accord with the ideology of the Chinese Communist Party), this poet will be detested in the jianghu circles.

Yi Sha's affiliation with Poetry Jianghu carries the personal, unofficial characteristics of jianghu as it is based entirely on his close friendship with Shen Haobo. As a fellow Beijing Normal University alumnus, though ten years younger, Shen has been Yi Sha's comrade in arms since the mid-1990s. ${ }^{184}$ When Shen was an undergraduate from 1995 to 1999 , he kept up a correspondence with Yi Sha to discuss avant-garde poetry. During the Panfeng Polemic, they were both representatives of the Minjian side. When Shen launched the Lower Body movement in 2000, Yi Sha was a steadfast supporter and became an active contributor to their website Poetry Jianghu. After Shen became a publishing tycoon in the 2010s, his Xiron Poetry Club 磨铁读诗会 become the major publisher of Yi Sha's work. The publication of five substantial volumes of Yi Sha shiji 伊沙诗集 (Collection of Yi Sha’s poetry) in 2017 clearly signalled Shen's treatment of Yi Sha as one of the most important avant-garde poets in contemporary China. In reciprocation, Yi Sha tirelessly promoted Shen Haobo's poetry in his various poetry activities.

Since Poetry Jianghu was such a relatively free space of contestations, fights and struggles, it became the venue to expose the private life of the Minjian Poets, including

\footnotetext{
${ }^{184}$ For Yi Sha, Beijing Normal University, his Alma Mater, plays an important role in his networking in the avantgarde poetry circles. As a prestigious university, BNU is a breeding ground of both academics and creative writers, especially poets. When Yi Sha studied as an undergraduate at BNU, his teachers included Liu Xiaobo (刘晓波, 19552017), then a prominent young literary critic and later a world-famous human rights activist and winner of Nobel Peace Prize, and renowned poets such as Ren Hongyuan 任洪渊 (b. 1937) and Zheng Min 郑敏 (b. 1920). Three of Yi Sha's classmates later became accomplished poets in their own right: Xu Jiang, Hou Ma and Sang Ke 桑克; the first two of them are associated with the Minjian group.
} 
their friendships, conflicts and personal experiences. Some of the major Minjian Poets, Yi Sha and Shen Haobo in particular, are larger-than-life figures; thus they often drew the attention of the audience not only by the poems they published online but by their personal life exposed in their online debates. One spectacular public display of personal fallout took place in 2007, when Yi Sha and Shen Haobo respectively ended their friendship with the more senior poet Yu Jian. Yu Jian, Yi Sha and Shen Haobo were all major Minjian Poets, who stood on the same side during Panfeng Polemic, and Yu was then the standard-bearer of the group. However, Yi Sha and Shen Haobo each later broke with Yu Jian; both incidents happened online and were exposed to the public. According to Shen Haobo, the two incidents, though they happened almost simultaneously, were due to different reasons. Shen broke with Yu because Shen was critical of Yu's advocacy of 'the ancient taste' 复古主义. Yi Sha's break with Yu was because Yi Sha published a poem that satirizes Yu's 'unnatural' behaviour when Yu had attended a writers' conference at the Great Hall of the People 人民大会堂. ${ }^{185}$ Shortly thereafter, and later that year, Yu Jian won the Lu Xun Literary Prize 鲁迅文学奖, one of the highest official literary awards in China but one that is often associated with bribery scandals. ${ }^{186}$

The primary reason for their break was not Yu Jian's acceptance of the scandalous official award. For Shen Haobo, Yu was no longer 'avant-garde' in aesthetics. For Yi Sha, Yu's 'unnatural' behaviour at the Great Hall of the People revealed the unsteadiness of his minjian standpoint. In other words, at least in the eyes of Shen Haobo and Yi Sha, Yu Jian had broken the jianghu rules by currying favour with the authorities. As I stated above, unofficialness is not the same as antiofficial, a poet in poetry jianghu can accept official awards on the condition that they do not break the

\footnotetext{
185 Shen Haobo 沈浩波. 'Zhongguo shige de canren yu guangrong' 中国诗歌的残忍与光荣 (The cruelty and glory of Chinese poetry), http://www.poemlife.com/libshow-2011.htm, accessed 9 October 2017.

186 A keyboard search on Google can find many results about the scandals of the award, for instance, 'Lu Xun Wenxue Jiang pingjiang chouwen buduan dianwu Lu Xun' 鲁迅文学奖评奖丑闻不断玷污鲁迅 (Scandals about Lu Xun Literary Prizes ceaselessly defile Lu Xun), http://star.news.sohu.com/20150707/n416284173.shtml, accessed 10 September 2017.
} 
jianghu rules, that is, by becoming aesthetically official or fishing for fame within the official literary establishment.

As their online dialogues on Poetry Jianghu are no longer available, the details of their quarrels are unclear, but a blogger once posted part of the dialogue between Yu Jian and Yi Sha in his own blog, which is still available. ${ }^{187}$ From this segment we can see, interestingly, that the last words Yu Jian said to Yi Sha were: 'To hell with you! Leaning back and laughing loudly I go out of the door’ 去你妈的吧, 仰天大笑出门去. The latter part of this line is a quote from Li Bai's 'Nanling bie ertong rujing' 南陵别儿童 入京 (In Nanling, I bid farewell to my children before going to the capital):

Leaning back and laughing loudly, I go out of the door.

How can such men as I keep staying among the weeds?

\section{仰天大笑出门去,}

我辈岂是蓬蒿人。1 188

The poem was written in 742 by Li Bai in over-excitement after being summoned by the emperor, as he thought that he would again be able to enter officialdom. Penghaoren 蓬蒿人 (People among the weeds) is a metaphor for the common people, those outside officialdom, the 'unofficial' people. These two lines are generally understood as Li Bai's smugness and eagerness to secure an official position. The same smugness also appeared in Yu Jian's words as he was going out of the 'door' of jianghu and became an officially acclaimed, award-winning poet. Considering that he was quarrelling with Yi Sha, I think Yu Jian cited the first line of the couplet as a parody of Li Bai. As van Crevel argues, though the Minjian Poets are proud of being aesthetically unofficial, they

\footnotetext{
187 ‘Shen Haobo, Yi Sha yu Yu Jian de juelie jingguo’ 沈浩波、伊沙与于坚的决裂经过 (Shen Haobo’s and Yi Sha's breaks with Yu Jian), http://blog.sina.com.cn/s/blog a6f2b2ce0101oxiy.html, accessed 15 December 2019. ${ }^{188}$ Li Bai 李白. Li Taibai quanji 李太白全集 (The complete poems of Li Bai). Beijing: Zhonghua shuju, 1977, p. 744 .
} 
all want to become institutionally official. ${ }^{189}$ Yu Jian deliberately emphasized his official identity as a poet in his counterattack, which would have hurt the poets still in jianghu.

By citing the examples above, I do not mean to suggest that these private incidents are significant in themselves, but they are good examples to showcase the jianghu characteristics of the environment on Poetry Jianghu. The poets kept exposing not only their work but their private life, such as friendships and conflicts, making the Poetry Jianghu website a performative space for the minjian poets, at least in virtual reality. It is chaotic and full of 'politically incorrect' poetry and dramatic anecdotes, similar to the jianghu in martial arts fiction, yet it is of considerable value since public space for unofficial cultural activities remains scarce in contemporary China.

The nature of a poetry website is usually demonstrated by its luntan 论坛 (forum) section. Nearly every Chinese poetry website has a section called 'forum', where poets freely post their recent work online, make comments and exchange points of view. As Hockx argues, 'Such forums exist on websites all over the world, but it is fair to say that in China, where state regulation makes independent niche publishing difficult and where poetry continues to enjoy high cultural standing and relatively strong popularity, these online forums are exceptionally important.' 190 Both Poem Life and Poetry Jianghu have a forum. However, the former's forum is usually filled with a variety of poems and the poets do not often make comments. The situation is totally different in Poetry Jianghu's forum where the poems are generally avant-garde and the poets frequently make edgy comments, positive or negative, about the posted poems. The whole forum is a place of 'boisterous democracy' where young and unknown poets can quarrel and debate with established poets like Han Dong and Yi Sha. However, these debates often take place in a noisy, irrational way without careful reasoning, filled with diatribes, more like performances rather than serious debates.

189 Maghiel van Crevel. Chinese Poetry in Times of Mind, Mayhem and Money. Leiden: Brill, 2008, p. 10.

190 Michel Hockx. Internet Literature in China. New York: Columbia University Press, 2015, p. 142-43. 
On the Poetry Jianghu forum, polemics happened almost every day among the minjian poets themselves. These minor polemics drew the attention of many other people who, though not active participants, still enjoyed watching these debates. The scene was very similar to what usually happens on the streets of China where two people may be quarrelling or fighting with a large crowd of silent onlookers standing around them, watching their public display of anger or frustration. On such occasions, the subject of the dispute is not the concern of the audience, but the onlookers have a great time watching the quarrel or fight itself. As Yi Sha puts it, 'Later we found many poets-we didn't know them and they didn't appear on Poetry Jianghu, either-were peeping at us 'under water' 潜水. So we knew many people came to Poetry Jianghu to gawk, for there were a lot of quarrels and debates, and the poems were provocative-it seemed they were all idle people. ${ }^{191}$ The performers and the audience mutually constitute a space of 'boisterous democracy' outside the official poetry scene, a jianghu that is governed by its own rules rather than by the official institutions.

One of such polemics is the Shen-Han polemic 沈韩之争, between the Minjian Poets Shen Haobo and Han Dong around New Year's Day in 2001 on the topic 'What is avantgarde poetry?'. The polemic began in 2000 when Shen delivered a speech at the conference ‘90 niandai hanyu shige luntan' 90 年代汉语诗歌论坛 (Forum of Chinese poetry in the 1990s) in Hengshan, in which he criticized a number of avant-garde poets, including Han Dong. A few months later, Han wrote an essay in response, published in the January 2001 issue of Zuojia 作家 (Writer magazine). Han said that ‘literature=avant-garde; avant-garde=anti-lyricism’ 文学 $=$ 先锋; 先锋 $=$ 反抒情 invented by 'a new literary authority' (Shen Haobo) is an idiotic formula, and 'avantgarde till death'先锋到死 (Shen's words) is sensational nonsense. After seeing Han's essay, Shen began to retaliate on the Poetry Jianghu forum by claiming Han is 'not avant-garde'. ${ }^{192}$ According to Shen, Han did not have access to the Internet then, so he

191 Yi Sha, Interviewed by Liang Yujing, 2016, see Appendix.

192 Yi Sha 伊沙. 'Zhongguo shiren de xianchang yuansheng-2001 wang shang lunzheng toushi' 中国诗人的现 
went to a nearby Internet bar with two young men every day to debate with Shen. ${ }^{193}$ Their polemic immediately drew a large group of supporters, 49 poets in total, on both sides, and the entire debate lasted seven days and seven nights.

On the surface, the Shen-Han polemic was one about 'avant-garde poetry'. However, it was more a rivalry of poets than a serious debate, just like a minor Panfeng Polemic, full of jianghu characteristics. When it happened, many poets expressed their views towards this polemic-Yang Li considered it as one between minjian and pseudominjian 伪民间 and A Fei 阿斐 said it revealed the conflict of interests between different poetry schools. ${ }^{194}$ Nevertheless, for such polemics, it is more appropriate not to investigate its meaning but to see it as a social function on the jianghu and the unofficial side of the Chinese poetry scene.

A comment from Yi Sha, perhaps, may best explain the Shen-Han polemic:

It would be undoubtedly rather disappointing to analyse this online polemic from a traditional perspective, due to its unclear nature and meaninglessness. Then, let's understand it from another angle: so many poets, with their real identity, revealed their true self through aggression to others in a crazy carnival of languagewouldn't this be more interesting than those damned talks about such things as nature and meaning?

用传统思路来总结这次发生在网上的争论无疑会相当失望，性质不明，意 义全无。那么我们就换个思路来理解它吧: 那么多有名有姓的诗人在网上

场原声—2001 网上论争透视 (The live soundtrack of Chinese poets: an insight into online polemics in 2001). In Yi Sha 伊沙, Zhongguo xiandai shilun 中国现代诗论 (On modern Chinese poetry), Taipei: Showwe Information, 2011, pp. 147-48.

193 Han Fanghang 韩方航. 'Shiren shangwang, 17 nian qian “qitian qiye” lunzhan beihou, shi zenyang yige jianghu' 诗人上网, 17 年前 “七天七夜” 论战背后, 是怎样一个江湖? (Poets going online: what a jianghu lay behind the 'seven-day, seven-night' polemic 17 years ago), 18 September 2017. https://www.qdaily.com/articles/45263.html, accessed 12 September 2019.

194 Ibid. 
性情外见、峥嵘毕露、言语狂欢——这不是比性质、意义这些鸟玩意更有意 思吗? 195

Clearly, Yi Sha thinks it is a natural and interesting phenomenon that the poets go online to show their points of view and personalities rather than hiding themselves away from the public, even if those polemics are unimportant and trivial. He believes this online performance of poets is a sign of the prosperity of poetry. Yi Sha's view coincides with van Crevel's attitude towards the Panfeng Polemic, and the Shen-Han polemic was like a minor Panfeng Polemic among the Minjian Poets themselves. For such a polemic, it is better to consider it as a social phenomenon rather than to investigate its aesthetic meaning. Similar polemics on Poetry Jianghu also included the Shen-Yi polemic (Shen Haobo and Yi Sha), the Xu-Han-Xiao-Yang polemic (Xu Jiang, Han Dong, Xiao Chen 萧沉 and Yang Li) and the Han-Yu polemic (Han Dong and Yu Jian).

The Shen-Yi polemic, which happened in June 2001 between good friends Shen Haobo and Yi Sha, is another instance that deserves mention. It started when Xiao Chen published an article online, stating that the post-1970 poets largely wrote in the style of Yi Sha and their poetry was the imitation of Yi Sha's work. ${ }^{196}$ Yi Sha made a positive comment below Xiao's post, which displeased Shen Haobo. As a post-1970 poet himself, Shen disagreed with Xiao's point of view and did not think that he himself was 'imitating' Yi Sha. Besides, Shen saw Yi Sha's positive comment on Xiao's article as an example of Yi's self-importance. The polemic started with a debate between Shen and Yi but soon became a messy one between Yi Sha and nearly all the Lower Body Poets (mostly post-1970 poets). This polemic also ended without a resolution and it did not affect the friendship between Shen Haobo and Yi Sha.

195 Yi Sha 伊沙. 'Zhongguo shiren de xianchang yuansheng-2001 wang shang lunzheng toushi' 中国诗人的现 场原声—2001 网上论争透视 (The live soundtrack of Chinese poets: an insight into online polemics in 2001). In Yi Sha 伊沙, Zhongguo xiandai shilun 中国现代诗论 (On modern Chinese poetry), Taipei: Showwe Information, 2011, p. 151.

196 Ibid, p. 152. 
On the Poetry Jianghu forum, such polemics were everyday occurrences, which reveals that there exists an unofficial space outside the official Chinese poetry scene, in which poetry and poetry-related polemics are generated every day, a minjian and a jianghu, more energetic and dynamic than the official poetry scene. These polemics also reflect the duality of minjian both as a strategy and an ideal. The poets exhibited their eloquence, personalities, temperaments and self-images on the stage of Poetry Jianghu, while their respective poetics are also demonstrated in such performances. It is inappropriate to judge these polemics as either poetic or non-poetic, for they are both.

Poetry Jianghu was undoubtedly the most typical case of minjian on the Internet and the major venue for Yi Sha's activities. It was a pioneer and representative of numerous unofficial poetry websites and online forums that mushroomed in the 2000 s, the online forum age of Chinese poetry, a period when the most dynamic poetry scene turned out to be the Internet rather than the official magazines. Even the former unofficial paperbased magazines became less influential than their online forums. ${ }^{197}$ In the case of the Lower Body Poets, their paper-based magazine Xiabanshen 下半身 (Lower body) was definitely far less influential than their website Poetry Jianghu.

The cultural maverick or outlaw character of Poetry Jianghu is dramatically played out in the demise of the website itself. In 2004, Shen Haobo, one of the most active poets on the website and the leading poet of the Lower Body group, published his first official collection Xin cang dae 心藏大恶 (Great evil hidden in the heart). The poems in this book, all previously published on the site, are both wickedly erotic and politically satirical. Soon, this book was banned and the editors in charge were dismissed from Dalian Press, the publisher of Shen's collection. Shen Haobo and Yin Lichuan, another Lower-body poet, were then investigated by the authorities. Later, Shen's friends in the government told him to run away 'without even a minute's delay'. ${ }^{198}$ Shen escaped to

\footnotetext{
197 For example, both Tamen 他们 (Them) and Feifei 非非 (Not-not) had their online forums in the 2000s.

198 Shen Haobo 沈浩波. 'Na yiduan lishi, wo hai congwei hepan tuochu: zai taopao de rizi li' 那一段历史, 我还 从未和盘托出: 在逃跑的日子里 (On that bit of history, I have never yet laid it all out: my days on the run),
} 
Malaysia via Hong Kong, then to Norway, before coming back to China, though he was not sure whether he would be arrested. Fortunately, he was not detained. After Shen's 'exile' incident, the Lower Body group dissolved, but their website Poetry Jianghu kept functioning until its final shutdown in 2010 . The online poetry forums gradually died out in the 2010s when new media such as blogs (Sina and Weibo) and smartphone apps (Wechat) began to flourish, and the cultural space of minjian had to yet again be staked out or invented.

\section{Chang'an Poetry Festival: The Institutionalization of Minjian}

The establishment of Chang'an Poetry Festival in 2010 marked a new stage in Yi Sha's career as a poetry activist, signalling the institutionalization of minjian as poetic practice. In the poetry scene of contemporary China, it is common for a group of poets to gather together and form a shiqun 诗群 (poetry group), usually based on their similar aesthetic views, and often revolving around some form of publication. For example, the Obscure Poets and their unofficial publication Today, Them and their publication Them, as well as the Lower Body Poets and their journal The Lower Body. Most of these poetry groups are informal communities whose members are loosely connected to each other. Their membership is unstable and susceptible to change. Their activities are mostly based on the compilation of their publications. Although also taking the form of irregular but frequent poetry gatherings of like-minded poets, Chang'an Poetry Festival distinguishes itself from most poetry groups through its highly organized poetry activities. The name is somewhat misleading, for it has never been an officially sanctioned public event, as the word 'festival' suggests. However, under the leadership of Yi Sha, Chang'an Poetry Festival has gradually taken on characteristics that mimic, and perhaps appropriate, those of an official institution. Yi Sha's efforts to promote and 'mainstream' minjian poetry have broader implications on 
what minjian signifies and the kinds of cultural space that poetry can occupy in today's China.

Chang'an Poetry Festival was established on 10 January 2010 when the New Yorkbased poet Yan Li visited Xi'an. To meet Yan Li, a group of local poets, including Yi Sha, gathered at a bar to read and talk about poetry. After the meeting, one of the poets, Qin Bazi 秦巴子, wrote an article 'Chang'an de shige jie' 长安的诗歌节 (A poetry festival of Chang'an), announcing the establishment of Chang'an Poetry Festival. Then the festival had six regular members: Yi Sha, Qin Bazi, Xidu Heshang 西毒何歾, Wang Youwei 王有尾, Zhu Jian 朱剑, Huang Hai 黄海 (later known as Huang Haixi 黄 海兮) and Ai Hao 艾蒿. They meet irregularly at cafés, bars and restaurants and hold poetry events which usually include readings and discussions about poetry. Usually when a member's poet friend comes to Xi'an, they would hold an event. Even if there are no guests, they would hold events, though irregularly, once or twice a month. In 2016, Qin Bazi withdrew from the group probably due to health problems and a deafmute poet, Zuo You 左右, became a new member. In 2017, Ai Hao moved to Chongqing and thus left Chang'an Poetry Festival, but he still keeps a close connection with the organisation. In 2019, a young poet, Li Haiquan 李海泉, Yi Sha’s student, became a new member. The current members of the Festival include Yi Sha, Xidu Heshang, Wang Youwei, Zhu Jian, Huang Haixi, Zuo You and Li Haiquan. Chang'an Poetry Festival has an online presence and is facilitated by digital technology such as blogs and WeChat. Their poetry gatherings may look traditional, but its organization and outreach are not. According to their 'official' blog, up to 28 November 2017, they had held 290 poetry events. ${ }^{199}$ According to a Wechat post by Yi Sha, by 6 September 2019, they had held 344 poetry events. ${ }^{200}$

\footnotetext{
199 See the blog of Chang'an Poetry Festival 长安诗歌节的博客: http://blog.sina.com.cn/changanshigejie, accessed 25 March 2018.

200 Chang'an Poetry Festival originally published the information about their events through their blog, but later they moved to more popular media such as Weibo and Wechat. They stopped updating their blog about poetry events on 28 November 2017, with a few announcements of awards in 2018.
} 
A glimpse at the blog of Chang'an Poetry Festival would indicate that it is a typical minjian poetry organisation. The adoption of the name 'Chang'an' itself suggests a rival claim on China's classical poetic tradition, or heritage, from an 'unofficial' standpoint. It is also interesting, and perhaps ironic, that avant-garde poets such as Yi Sha would choose to align themselves with the classical poets (who had long been canonized and 'officialised') in order to boost their cultural prestige and symbolic capital. On the home page of their blog, there is a 'permanent theme poem' 永久主题诗 for the festival, an excerpt from Du Fu's 杜甫 'Yin zhong baxian ge' 饮中八仙歌 (Eight drinking immortals). These four lines are about Li Bai:

Li Bai makes a hundred poems out of one quart of ale, in the marketplace of Chang'an he sleeps in the tavern.

The Son of Heaven called him to come, he wouldn't get on the boat, he himself declared: 'Your subject is an immortal in his ale.'201

李白斗酒诗百篇,

长安市上酒家眠。

天子呼来不上船,

自称臣是酒中仙。

Du Fu's original poem depicts eight exceptional drinkers of his time, especially their unconventional deeds in drunkenness. These lines about Li Bai are well-known for their exhibition of Li Bai's unruly and rebellious personality. A contrast between the official and the unofficial is also included in the excerpt, as the emperor (Son of Heaven) stands for the authorities, the official, and Li Bai the poet represents the unofficial. In these lines, Li Bai refuses a summons from the emperor because he has poetry and wine, which are dearer to him than power. With poetry and wine, he has the courage to claim himself an 'immortal', as if he were beyond the reach of the emperor. By using these

201 Stephen Owen, ed. and trans. The Poetry of Du Fu. Boston, MA: De Gruyter, 2015, p. 55. 
lines as its theme poem, Chang'an Poetry Festival demonstrates its connection with the 'unofficial' tradition in classical Chinese poetry. Like Li Bai in the poem, the poets show contempt for the authorities while they have poetry and wine.

Apart from the theme poem, an announcement on their blog states their unofficial stance even more clearly. It defines Chang' an Poetry Festival as a 'private party and gathering for friends and poetry' 私人的、朋友的、诗歌的聚会与汇聚. ${ }^{202}$ This statement reveals the initial ideal of the poetry festival with three key elements: 1 . To be private, which means it is not for the public and only among a small group of avant-garde poets. 2. It is for friends, which is understandable, considering that most of its events are held when the friends of its members visit Xi'an. 3. It is for poetry, as all the visitors to its events are poetry-related people, including poets, critics and poetry lovers. The emphasis of Chang'an Poetry Festival on private membership set up a model for a number of followers, such as Quancheng Poetry Festival 泉城诗歌节 and Jiangnan Poetry Festival 江南诗歌节. ${ }^{203}$ Moreover, another statement that appears at the end of the announcement intensifies this impression: Chang'an Poetry Festival says no to crashers, says no to non-poetic elements 长安诗歌节谢绝不速之客, 谢绝非诗因素 介入. Here 'crashers' would easily remind the reader of the frequent polemics on the Chinese poetry scene, especially the Panfeng Polemic. If 'friends' refer to those who are Colloquial poets and who do not object to Colloquial Poetry, 'crashers' are undoubtedly those who object to it. At least, no Intellectual poets ever attend Chang'an Poetry Festival gatherings. 'Non-poetic elements' seemingly allude to the bureaucracy and corruption which are common in the official poetry events. All these elements show that 'unofficialness' is becoming increasingly complex and multi-layered.

\footnotetext{
202 See The blog of Chang’an Poetry Festival 长安诗歌节的博客: http://blog.sina.com.cn/changanshigejie, accessed 25 March 2018.

203 Quancheng Poetry Festival was founded in 2015 in Jinan by poets like Tie Xin 铁心 and Xuanyuan Shike 轩 辕轼辑. Jiangnan Poetry Festival was founded in 2018 in Nanjing by poets like Dayou 大友 and Ye Zhen 叶臻. There are about a dozen of such unofficial poetry organisations founded by minjian poets which follow the model of Chang'an Poetry Festival.
} 
In January 2016, I attended a Chang'an Poetry Festival event as a visiting poet and had the chance to witness the full proceedings of a typical poetry reading event. The members who attended that event included Yi Sha, Qin Bazi, Xidu Heshang, Wang Youwei, Huang Hai and Zuo You. There were two visitors: Wang Fei 王飞, a young poet-scholar from Hunan and I. The event began with a dinner at the members' expense. Then all the people moved to a café to read poetry. Xidu Heshang, the then-president of the festival, introduced the history of Chang'an Poetry Festival to the visiting poets. Then, all the attendees started to read their own poetry one by one, one poem from each person. After one finished reading a poem, the others made comments on it. The discussions were generally serious, and occasionally heated. However, Yi Sha acted as a referee, giving final judgement on each poem. After he made comments on a poem, generally no one would comment further, and the next person started to read a new poem. It was like a family poetry party where Yi Sha acted as the patriarch. The whole process was a combination of jianghu brotherhood (dinner, drinking and making friends) and serious discussions about poetry (reading poetry and making comments). In the dinner part, there was no difference between Chang'an Poetry Festival and other gatherings of poets, with an atmosphere of brotherhood. But in the poetry reading and discussion part, there was an order and a patriarchy, which added institutional elements to this unofficial organisation.

Though launched with distinctly unofficial elements, Chang'an Poetry Festival soon stood out on the unofficial poetry scene with its institutional characteristics rarely found in other such organisations and poetry groups. This has made it more like an organised institution than other unofficial poetry groups, such as the Lower Body Poets. The most distinctive and impressive feature of Chang'an Poetry Festival as an institutionalised body is the detailed records of its events that are openly available online to the public, which is rare among the unofficial poetry groups in China. Chinese organisations generally do not pay enough attention to archiving, and it is not easy to find online systematic information on many influential poetry awards, such as Anne-Kao Poetry 
Award 刘丽安诗歌奖 and Rougang Poetry Award 柔刚诗歌奖. Only a few literary organisations have their own websites that make their archives available to the public. However, the archives about the events of Chang'an Poetry Festival are almost completely available on its blog and other media, and few Chinese organisations have such a detailed record.

Chang'an Poetry Festival's emphasis on the open access to their archives shows an effort to compete with the official institutions, for Chinese official organisations tend to hide their information and make their archives difficult to access. For each of the Chang'an Poetry Festival events, the online report usually includes the basic information (time, venue and attendees), a few pictures, the poems they read, a summary of others' comments as well as some important points of view about writing poetry. Take its sixtieth event as an example. The details of the sixtieth event of Chang'an Poetry Festival are completely available online. ${ }^{204}$ The page of its report indicates that the event was held on 11 June 2011 at Green Island Café 绿岛咖啡 due to the visit of two critics, Huo Junming 霍俊明 and Cui Yong 崔勇. Four of the festival's members were present: Yi Sha, Zhu Jian, Xidu Heshang and Wang Youwei. Then the page gives a list of poems each person read at the party with a few remarkable comments, such as 'poetry is an eternal subtraction'. ${ }^{205}$ Several pictures of the poets and critics reading poetry are also available on the page. Fairly speaking, it is not uncommon to find such a poetry event report occasionally on other unofficial organisations' websites, but a complete archive of more than 290 events available online - this is an unusual project that most other unofficial organisations fail to accomplish. These archives make Chang'an Poetry Festival look formal and institutionalised, thus having a positive publicity effect. In this sense, Chang' an Poetry Festival distinguishes itself from other poetry organisations and appears like a formal institution with transparent archives to carve out an alternative public space for cultural

\footnotetext{
${ }^{204}$ See the blog of Chang'an Poetry Festival 长安诗歌节的博客:

http://blog.sina.com.cn/s/blog 6535d6420100s4vl.html, accessed 4 May 2018.

205 Ibid.
} 
influence and prestige. Yi Sha's group is not only testing the boundaries between official/unofficial spaces, but also playing with the idea of private/public space. On the one hand there is strict gate-keeping (private membership, friends only), on the other hand, there is a tremendous effort towards public exploration and open access (online). This paradox reveals the efforts of the minjian poets who intend to stick to their own aesthetic beliefs and to make them more influential, but also a representation of the duality of minjian.

Apart from the detailed record of its events, Chang'an Poetry Festival also has a set of regulations which are carried out strictly, showing a prototypic democracy, a quality often missing in the autocracy of the official institution. Each member has their own work and the chairmanship of the festival rotates annually. The regulations, once updated, are announced somewhere on its blog. For instance, the report on No. 95 event includes a few updates of the regulations, such as 'In principle, an event of Chang'an Poetry Festival can only be held on the condition that more than half of the members are present' and 'In special circumstances, if there are not more than half of the members due to objective reasons, then the event is subject to the approval of the chairman on the condition that it meets the requirements of Chang'an Poetry Festival in form, content and quality'. ${ }^{206}$ On the same page, there is a regulation about recruiting a new member: 'A new member can only join the festival through a vote of all the current members, by the rule of “one-vote veto”一票否决, namely the unanimous consent of all of the seven members. ${ }^{207}$ There is also a rule about its independence: 'Chang'an Poetry Festival regards poetry above all and sticks to the principle of "being private, for poetry and friends". It can join in or host a variety of literary events if these are observed. In principle, it has to be independent and does not accept any form of incorporation.' In general, these regulations are strictly observed. For example, when Zuo You wanted to become a new member in 2016, it took him several months to get

\footnotetext{
206 See the blog of Chang'an Poetry Festival 长安诗歌节的博客: http://blog.sina.com.cn/s/blog_6535d64201015zax.html, accessed 5 April 2018. 207 Ibid.
} 
the unanimous consent of the other members.

The second form of institutionalisation is imbedded in the awards of Chang' an Poetry Festival. Though there are numerous unofficial poetry awards in China, the awards of Chang' an Poetry Festival have their own characteristics, for they are a system of awards with their unique poetic value judgement, rather than a random award given to the best poet and poems. The Chang'an Poetry Festival awards consist of three categories: Modern Poetry Achievement Award 现代诗成就大奖, Tang Young Poet Award 唐·青 年诗人奖 and Tang Hall of Fame 唐·名人堂. The awards are announced annually on 1 January through the vote of the festival's members. The poets who attended the events during the previous year are automatically considered for the awards. The Young Poet Award was originally for poets under 35 , but later for poets under 40 , as the rules were changed. Any poet who gets votes for both awards will enter the Tang Hall of Fame. The Chang' an Poetry Festival awards do not and will never give monetary rewards, but each recipient receives a trophy or certificate, because the festival does not accept any commercial sponsorship - this in order to make the awards 'objective and fair' and maintain a 'pure poetic spirit'. 208

These awards constitute a system that represents the minjian poetic aesthetics through its emphasis on Colloquial Poetry and unofficial stance. A look at the list of winners of the major award, the Modern Poetry Achievement Award, will reveal it is a congregation of almost all of the important Minjian Poets or Colloquial Poets. The winners include Yan Li (2010), Xu Jiang (2011), Shen Haobo (2012), Ma Fei (2013), Tang Xin (2014), Hou Ma 侯马 (2015), A Wu 阿吾 (2016), Han Dong (2017) and Li Yan 李岩 (2018). Yan Li is a representative of post-Obscure Poetry and early Colloquial Poetry, who founded the poetry journal A line in New York. Xu Jiang, Shen

\footnotetext{
${ }^{208}$ Xu Ying 许荣. 'Shiyi de “wutuobang”- tanfang Chang' an shigejie muqian muhou’ 诗意的 “乌托邦” ——探 访长安诗歌节幕前幕后 (A poetic utopia: before and behind the scenes of Chang'an Poetry Festival). Shidai renwu 时代人物 (Times figure), No. 6, 2011, p. 83.
} 
Haobo and Hou Ma are all typical Colloquial Poets and Yi Sha's Beijing Normal University alumni. Ma Fei and Tang Xin are Yi Sha's long-time fellow poets. A Wu, a precursor of Colloquial Poetry in the 1980s, returned to China after many years' stay in New Zealand. Han Dong was a leading Minjian Poet during the Panfeng Polemic. Li Yan is a representative Colloquial Poet based in Shaanxi. These winners have a few things in common: 1. They are all representative Colloquial Poets, or champions of Colloquial Poetry. 2. They have stayed almost outside the official poetry scene and seldom won any official awards. Among these poets, only Shen Haobo and Han Dong have some reputation in the official poetry circle, but they were both known as representative Minjian Poets in the Panfeng Polemic. 3. They are all relatively old poets who have certain influence over the Chinese poetry scene. Shen Haobo, born in 1976, is the youngest, but he became an established poet at a very early stage of his career by leading the Lower Body movement. 4. They all keep a good relationship with Yi Sha, at least at the time of receiving their award. The last point may sound paltry, but it is also an important rule on the Chinese unofficial poetry scene, or the jianghu of Chinese poetry. An instance is Yu Jian, who, as the leading Minjian Poet during the 1999 Panfeng Polemic, broke with Yi Sha in 2007. Yu Jian has never attended any Chang'an Poetry Festival events and, consequently, has never received an award.

The four common features of the winners also show the duality of minjian both as an ideal and a strategy. I have explained this duality in my discussion of Yi Sha's polemic articles, which, for Yi Sha, are both a method to preach his ideal of minjian and an opportunity to legitimate the Minjian Poets. This duality of minjian appears again in the list of Chang'an Poetry Festival award winners - a winner must be a representative of Colloquial Poetry and unofficial stance, as well as an influential poet who keeps a good relationship with the members of Chang'an Poetry Festival. The standard of the award is a combination of aesthetics and politics. Among the four common features, 1 and 2 are aesthetical standards, while 3 and 4 are strategic standards. Therefore, the award is neither completely based on aesthetical standards nor merely a result of politics, but a combination of poetic evaluation and jianghu rules. Fairly speaking, this duality 
is a common phenomenon that almost always exists in all the unofficial poetry awards in China. The official awards are even worse, because they, being highly profitable, are more likely to be affected by bribery and personal relationships, such as the bribery scandals about the Lu Xun Literary Prizes. Chang'an Poetry Festival awards distinguish themselves from the official awards and other unofficial awards because, despite the jianghu rules, they indeed have a solid aesthetical standard, which makes them notable on the Chinese poetry scene.

Though Chang'an Poetry Festival claims itself as an 'unofficial' organisation, the awarding process itself is also a form of institutionalisation and canonisation. By awarding an influential Colloquial poet every year through its Modern Poetry Achievement Award, Chang'an Poetry Festival has come up with a list of poets who constitute the major force of Colloquial Poetry since the 1990s. With its standards of Colloquial Poetry and unofficial stance, this list demonstrates the efforts of Chang'an Poetry Festival to establish a canon for Chinese minjian poetry. As time goes on, more and more minjian poets will be put in this canon and it will become a list that is completely different from the official version of important contemporary poets, such as the Lu Xun Literary Prize winners. Like the Modern Poetry Achievement Award, the Tang Young Poet Award is also given to the Colloquial and unofficial poet, only younger in age. Its winners include Han Jingyuan 韩敬源 (2013), Li Yi 李异 (2014), Zuo You (2015), Wu Yulun 吴雨伦 (2016), Ai Hao (2017) and Yang Yan 杨艳 (2018). Among these winners, Han Jingyuan and Li Yi are Yi Sha's former students and faithful followers in poetry; Zuo You later became a member of Chang'an Poetry Festival (but not when he received the award); Wu Yulun is Yi Sha's son; Ai Hao is a former member of Chang'an Poetry Festival (not when he received the award); Yang Yan, the only woman, is a Colloquial Poet who insists on her unofficial stance. Here the duality of minjian reappears. Though most of these Young Poet Award winners have a personal relationship with Yi Sha, they do form a representative list of young poets with minjian characteristics. Through the awarding process, Chang'an Poetry Festival has tried to create a canon of the young minjian poets. 
The third characteristic of Chang'an Poetry Festival as an institutionalised organisation is its interactions with other official and unofficial organisations. A typical example is a series of events they have held at the Xi'an-based universities. In these events, they collaborated with the local universities to hold poetry readings, give talks on poetry and discuss poetry with the students. These activities of poetry education make Chang'an Poetry Festival a poetry brand among the local university students and its members are known by them. Though they often come across students who do not agree with their poetics, there are still quite a few students who have started to write poetry under their influence. According to a news report, from 2014 to 2016, in more than a year, they held poetry events at Shaanxi Normal University, Xi' an International Studies University, Northwest University, Chang'an University, Xi'an Fanyi University and Xi'an Jiaotong University. ${ }^{209}$ By collaborating with these universities in holding poetry events, Chang'an Poetry Festival has become an influential poetry organisation in Xi'an. Though Xi'an is not as prominent as Beijing, China's political centre, and Shanghai, China's economic centre, it is an important city for classical Chinese culture, especially classical poetry. As the capital of the Tang Dynasty, China's golden age of poetry, Xi'an (formerly known as Chang'an) is a symbol for the prosperity of Tang poetry. Chang'an Poetry Festival's insistence on calling itself 'Chang'an' instead of 'Xi'an' represents its ambition to revive the prosperity of Tang poetry and its attempt to merge itself into the poetic tradition of Chang'an by connecting the present to the ancient. In this sense, Chang'an Poetry Festival has gone beyond the official/unofficial binary and become an important poetry organisation with strong minjian elements.

\section{'New Poetry Classics': Canonization of the Minjian Poetry}

\footnotetext{
209 'Chang'an shige jie zhengfa xing: shi zai xin shiji’ 长安诗歌节政法行: 诗在新世纪 (Chang'an Poetry Festival at Northwest University of Politics and Law: poetry in the new century), https://kknews.cc/zhsg/culture/pokrv2.html, accessed 21 September 2019.
} 
Apart from the establishment of Chang'an Poetry Festival, an institutionalised social organisation of the minjian poets, Yi Sha's efforts to legitimise minjian poetry also include his editorship of 'Xin shiji shidian' 新世纪诗典 (New century poetry classics), or in short, 'Xin shidian' 新诗典 (New poetry classics or the NPC). It is a project starting in 2011 that presents one poem a day online for the reader with Yi Sha's introduction and after each year all the poems are published in print as a poetry anthology by Xiron 磨铁, Shen Haobo’s publishing company. Unlike Chang'an Poetry Festival which is an organisation of seven poets, the NPC is a project undertaken solely by Yi Sha himself. Though his fellow poets also work voluntarily for the project in respect of collecting statistics and recommending poems, the editorial decisions are entirely made by Yi Sha. Through seven years of continuous work, the NPC has exerted great influence on the Chinese poetry scene and become a trademark of Yi Sha. This project contributes to the concept of minjian in two ways. On the poetic level, it attempts to canonise Yi Sha's concept of Colloquial Poetry through his selection of poems. On the social level, it helps to build a social network of poets (mostly Colloquial Poets) through its various events and awards.

The NPC is not merely an anthology of contemporary Chinese poetry but a large, continuous, and unofficial project of presenting 'good poetry', based on Yi Sha's own judgement. Though this project involves many volunteers who help with its online design, statistics and organisation of events, Yi Sha plays the central role as its sole host and editor. The NPC project mainly consists of three components: 1. Online recommendation of a poem per day; 2, Yearly paper-based publication of an anthology 3. Awards. By this project, Yi Sha tries to build the canon of twenty-first century Chinese poetry, including not only Colloquial Poetry. In the following part of this section, I will discuss the three components of the NPC one by one.

\section{Online recommendation}


The launch of the NPC project was closely related to the rise of Weibo 微博 (microblog) in China. Microblogs appeared in China in 2007 as Fanfou 饭否 became the first Chinese microblog. Later it was shut down together with Twitter and Facebook by the government after the July 2009 Urumqi riots. However, this incident led to the boom of Weibo services offered by large Internet companies such as Sina 新浪 and NetEase 网易, who launched their microblogging services respectively in 2009 and 2010. In 2011, Yi Sha was invited by NetEase Book Channel 网易读书频道 to present one poem a day with a short introduction in his NetEase Weibo account. In the 1990s, when serving as an editor of Friends in letters, Yi Sha once hosted a similar poetry column named 'Shiji shidian' 世纪诗典 (Century poetry classics), which presented good poems in the twentieth century. ${ }^{210}$ Thus, the NetEase Weibo column was named 'New century poetry classics', focusing on poetry written in the twenty-first century. NetEase sponsored the NPC for a year, including three off-line poetry events, before it ceased funding the project. Then, the NPC became Yi Sha's personal business. After 15 December 2014 when NetEase shut down its microblogging service, Yi Sha continued his recommendation by moving to Sina Weibo 新浪微博 and Wechat.

The first poem Yi Sha posted online on 5 April 2011 for his NPC project was Shen Haobo’s 'Mali de aiqing' 玛丽的爱情 (Mary’s love), a controversial piece which depicts the unequal relationship between Mary, a senior employee, and her boss. The poem is largely a dialogue between the author 'I' and Mary's boss, who is proud of the fact that Mary is willing to do extra work for him without overtime pay because of their secret relationship. The reason is, 'I told her repeatedly I loved her, and she believed! 我一遍遍告诉她 / 我爱她, 然后她信了! ’211 The poem is controversial because the boss's words, imbued with male chauvinism, make the reader uncomfortable. However, the employer's emotional investment in the employee in order to make a profit soon

\footnotetext{
210 Tang Xin 唐欣. 'Chuzuche shiguo yizuo wuming daqiao-Xin shiji shidian' 出租车驶过一座无名大桥一一 新世纪诗典 (The taxicab rolls past a nameless bridge: New century poetry classics). Qinghai hu 青海湖 (Qinghai Lake), No. 8, 2015, p. 41.

211 Shen Haobo 沈浩波. 'Mali de aiqing' 玛丽的爱情 (Mary’s love). Yi Sha 伊沙, ed. Xin shiji shidian, diyiji 新世纪诗典, 第一季 (New century poetry classics, Vol. I), Hangzhou: Zhejiang wenyi chubanshe, 2012, p. 2.
} 
raised hot discussion in a variety of social media. ${ }^{212}$

In his introduction to 'Mary's love', Yi Sha explains why he chose Shen Haobo as the first poet in the NPC: 'I am to pick someone who grew up and matured in the new century, an outstanding poet who has a large influence both within and outside of the field, then Shen Haobo is undoubtedly the most appropriate choice. ${ }^{213}$ These words show that, when Yi Sha started compiling the NPC, his focus was more on the poet than on the poem. Though the choice of the poem was also important, Yi Sha demonstrates his ambition to build or rebuild the canon of Chinese poetry of the new century through his selection of both poets and poems. His method of selection is a combination of picking good poets and good poems. First, there is a list of poets which he thinks are important. Then, for unsolicited submissions, he just picks the poems which he thinks are excellent. This method ensures that he can include all the poets and poems he likes.

At a later period, Yi Sha gradually developed an effective procedure of selection. On the first and the fifteenth of each month, he selects fifteen poems from the submissions in the last half month, ten by old authors and five by new authors. In this way, he can keep a balance between the quality of selected poems and the number of selected poets, so as to maximise the possibility of including all the good poets and poems. Each year, there are three rounds of recommendation, which means a poet can be recommended three times at most, if he/she has his/her poem selected in every round.

Since the appearance of the NPC online, it has gathered a large group of followers and keen readers. Some of them have become volunteers helping with its statistics work. Therefore, the NPC project has a complete system of statistics, more detailed than many

\footnotetext{
212 'Yi Sha “Xin shiji shidian” toupao: Shen Haobo “Mali de aiqing” yin reyi’ 伊沙《新世纪诗典》头炮: 沈浩 波《玛丽的爱情》引热议 (The first bomb of Yi Sha's 'New Century Poetry Classics': Shen Haobo's 'Mary’s love' causes hot discussion), 2011, http://www.poemlife.com/newshow-6102.htm, accessed 10 May 2018.

213 Yi Sha 伊沙, ed. Xin shiji shidian, diyiji 新世纪诗典, 第一季 (New century poetry classics), Hangzhou: Zhejiang wenyi chubanshe, 2012, p. 2.
} 
other projects. This is also enabled by the development of technology. Every few months, the Weibo and Wechat accounts of the NPC publish an updated version of its statistics to show the general data of this project. For example, in early September 2019, the Weibo account of the NPC published five top ten lists of statistics regarding its online recommendations from January to August, including 'Yuedu bang' 阅读榜 (List of the most read poets), 'Zhuanfa bang' 转发榜 ( List of the most reposted poets), 'Pinglun bang' 评论榜 (List of the most commented poets), 'Renqi bang' 人气榜 (List of the most popular poets) and 'Zhongguo shida shige shengqu' 中国十大诗歌 省区 (List of the top ten poetry provinces in China). ${ }^{214}$ All these lists are based on the data collected from the Internet, such as Weibo hits, reposts and comments. The List of the Top Ten Poetry Provinces in China also reveals Yi Sha's ambition to build the canon of the twenty-first century Chinese poetry that includes all the poets writing in Chinese, a canon complied by an unofficial poet and supported by the strength of the volunteers rather than the official institutions.

Heather Inwood points out what functions in the NPC are 'gatekeeping dynamics', as Yi Sha's interest lies in asserting his authority as a successful poet and his right to decide what constitutes "good quality" poetry. ${ }^{215}$ She argues that Yi Sha 'appears to have chosen poems not just for being "outstanding" representatives of modern Chinese poetry but also in many instances for the controversial nature of their subject matter and their potential shock value.'216 This model of gatekeeping 'privileges the editorial authority of Yi Sha as a famous representative of China's arena, and aims for preservation and permanence by creating a body of "quality" poems to be later published in print and circulated on- and offline under the grand-sounding title of "New Century Poetry Classics", ${ }^{217}$

\footnotetext{
214 In fact, the NPC includes poets writing in Chinese all over the world, regardless of the author's race and nationality. On this list, Hong Kong, Macau, Taiwan and Overseas are each treated as a province.

215 Heather Inwood. 'Poetry for the People? Modern Chinese Poetry in the Age of the Internet.' Chinese Literature

Today, Vol. 5, No. 1, p. 48.

216 Ibid, p. 50.

217 Ibid.
} 
As a 'gatekeeper', Yi Sha tries to strike a balance between good poetry in general and Colloquial Poetry in particular in the NPC. On the one hand, he selects all the poems he is satisfied with. On the other hand, he gives priority to Colloquial Poetry. On 31 August 2019, Yi Sha posted a full list of recommended poets from the beginning of the NPC project in 2011 to 31 August 2019, including the number of recommended poems for each poet. ${ }^{218}$ This long, detailed list, a panoramic display of Yi Sha's NPC project, is entitled 'Quanqiu Zhongwen shige shili bang' 全球中文诗歌实力榜 (The strength list of global Chinese poetry). There are a few points to be noted:

1. The most recommended poets: There are four poets whose poetry has been recommended 26 times, which means they have never missed a round of recommendation by the NPC. They are Shen Haobo, Tang Xin, Ma Fei and Xu Jiang. Aesthetically, these four poets are largely Colloquial Poets, though some of them, like Shen Haobo and Tang Xin, are more flexible in their style. Moreover, the four poets are all Yi Sha's long-time friends and steadfast supporters. This may be explained again by the duality of minjian: what functions in poetry activities is a combination of aesthetics and politics. On the unofficial poetry scene, these two factors are united together and inseparable. Without similar aesthetics, poets are unlikely to become real friends. Without friendship, they are unlikely to support Yi Sha's project by persistently submitting poetry to the NPC.

2. Yi Sha himself, as the editor, has also been recommended 25 times, only one time less than the four most recommended poets. It is common practice in China, especially on the unofficial poetry scene, that a poetry editor includes his own work in an anthology that he edits. The 25 times is an appropriate number. It confirms the editor as an important poet, while it avoids the danger of self-importance by

\footnotetext{
218 'Xin shiji shidian quanqiu Zhongwen shige shili bang (2019.8.31 gengxin)' 《新世纪诗典》全球中文诗歌实 力榜（2019.8.31 更新）(The New Poetry Classics strength list of global Chinese poetry, updated 31 August 2019). In Yi Sha's Weibo: https://www.weibo.com/1218293911/I4Oqde4dR?type=comment\# rnd1569498407443, accessed 26 September 2019.
} 
excluding himself from the most recommended poets.

3. Intellectual Poets: Yi Sha's ambition is to include all the good poems written in Chinese, thus he would not totally reject what van Crevel calls 'the Elevated' poetry, a style of the Intellectual Poets who were the opponents of the Minjian Poets in the 1999 Panfeng Polemic. However, he keeps such poetry to a minimum. In his selection, he often chooses the relatively earthly poems of the Intellectual Poets. In the NPC, Zang Di has been recommended five times, Xi Chuan two times and Wang Jiaxin two times. The reason for this is partly because Yi Sha does not appreciate their style, and partly because they are not that interested in appearing in the NPC.

4. Children poets: Yi Sha discovered a dozen of talented children poets through the NPC, with You Ruoxin 游若昕 as their representative. You Ruoxin, born in 2006, was a primary school student when her poem was selected by Yi Sha in 2013. By the end of August 2019, her poetry has been recommended 19 times by the NPC, more than most of the adult poets, ranking as the 24th on the full list.

5. Non-Chinese poets writing in Chinese: There are a few foreign poets whose Chinese poems are included in the NPC, such as Denis Mair 梅丹理 (US), Martin Winter 维马丁 (Austria), Isolda Morillo 莫沫 (Peru) and Jami Proctor-Xu 徐贞敏 (US). Most of them are translators of Chinese poetry with a good command of Chinese. Denis Mair is the first English translator of Yi Sha. Martin Winter is the German translator of Yi Sha. Isolda Morillo is a journalist once based in Beijing, and also the Spanish translator of Shen Haobo. Their inclusion gives the NPC an international, transcultural scope, which is seldom found in many other poetry anthologies in mainland China.

6. From 5 April 2011 to 31 August 2019, the NPC project recommended one poem a day without stop, presenting 1021 poets in total. As its sole editor, Yi Sha has contributed greatly to contemporary Chinese poetry by undertaking such a huge 
project with the ambition of presenting a full view of twenty-first century Chinese poetry. Yi Sha has partially achieved this goal by presenting an extensive list of poets, including celebrated ones and many new discoveries, though he mainly focuses on Colloquial Poetry to create a voice to compete with the official poetry circles.

\section{Paper-based publication}

The NPC started in 2011 as an online project, but the following year witnessed its first publication of a print anthology. From then on, each year's recommended poems were put together and published as a print volume. By September 2019, seven volumes of the NPC have been available in print. The print anthology is normally published in the following year after the poems are recommended online, but occasionally there is a delay and two volumes come out together in the next year. For example, Volume Four and Five were both published in 2016, while Volume Six and Seven came out in 2018.

The act of going in print was a significant step for Yi Sha and the NPC, for it was a sign that, to some extent, this unofficial project became mainstream, a sign of legitimation and an effort towards canonisation. In terms of publication, the Internet, though a relatively freer space, has its drawback - it contains too much crappy and unstable information. Such a circumstance would limit the influence of the NPC if it only existed online. Going in print gave the NPC the opportunity of becoming a stable, legitimate publication, and made it able to avoid the risk of disappearing in the ever-changing cyber world. Though print publication means more strict censorship and a few poems had to be removed, it is still a better option for the NPC than merely staying online, a step from jianghu to official publication.

However, the key figure who helped to bring about its official publication was an unofficial poet-Shen Haobo, also the CEO of Xiron Books, China's largest private publisher. For Yi Sha and the NPC project, Shen's role is a triple one: contributor (one 
of the four most recommended poets), publisher (print anthologies) and patron (awards). Shen's support for Yi Sha and the NPC project is multifaceted. Without Shen, the NPC would not have been so influential as it is nowadays.

In a sense, all the formal, paper-based publications in mainland China can be regarded as 'official'. Though Shen's company is often referred to as a 'private publisher', it is in fact a company only dealing with book production and distribution. In China, there is no real private 'publisher' and the publishing industry is still controlled by the government, because only the state-owned, 'official' publishers can get ISBNs and thus 'publish' a book. However, the government allows private capital to go into the publishing industry, which is the case of Shen's company, Xiron. To publish a book, Xiron has to collaborate with an 'official' publisher. Though the book is proposed, designed and perhaps distributed by Xiron, it has to get an ISBN from the 'official' publisher and has to be 'published' by the official one, only with the trademark of Xiron. Accordingly, the content of the book has to be censored and approved by the 'official' publisher. Take Xin shiji shidian, diqi ji 新世纪诗典, 第七季 (New century poetry classics, vol. 7) for example, it was proposed and designed by Xiron, but it shows on its cover that its publisher is China Youth Press 中国青年出版社, with the trademark of Xiron Poetry Club 磨铁读诗会 on its spine. China Youth Press, the 'official' publisher, is the one responsible for the content of the book. If the government considers the book 'politically problematic', China Youth Press is the first to be punished. Therefore, to formally publish a book in China (with an ISBN) is a way to become 'official', but this officialization can be realized through the help of private companies like Xiron.

Awards

Like Chang'an Poetry Festival, the NPC also has its own system of awards, known as the NPC Annual Awards 《新世纪诗典》年度大奖 from 2012 to 2013 and the NPC 
Li Bai Poetry Awards 《新世纪诗典》李白诗歌奖 since 2014. In March 2012, the ceremony of the first NPC Annual Awards was held in Guangzhou under the patronage of NetEase. In the second year, NetEase ceased to sponsor the NPC; Xiron, Shen Haobo's publishing company, became its new patron. They held the 2013 ceremony in Beijing. From 2014 onwards, Yi Sha found a permanent home for the award ceremony: Jiangyou, Mianyang, Sichuan Province, which is noted to be the hometown of Li Bai. Since then, the awards were named after Li Bai. Shen Haobo still acts as its patron and provides financial support such as award money.

The current NPC Li Bai Awards have eight awards, with their winners announced at the beginning of each year through Yi Sha's social media. These awards include Achievement Award 成就奖 (for life achievement in poetry), Gold Poetry Award 金 诗奖, Silver Poetry Award 银诗奖, Copper Poetry Award 铜诗奖 (for the best poems in a year), Comment Award 评论奖 (for Weibo comments on the recommended poems), Translation Award 翻译奖 (for translating the NPC poems into foreign languages), Recommendation Award 推荐奖 (for recommending new poets to Yi Sha) and Culture Award 文化奖 (for social and cultural contribution to the NPC, such as organisation of events).

Interestingly, in 2015, one year later than the birth of the NPC Li Bai Poetry Awards, there appeared an official Li Bai Poetry Award 李白诗歌奖 in Mianyang, co-hosted by Mianyang Li Bai Poetry Society 绵阳李白诗歌协会 and the Poetry Institute of China 中国诗歌学会, both official organisations. The official Li Bai Poetry Award, awarded every other year, has a very high monetary value: one million yuan in total for the winner and five nominees. ${ }^{219}$ A comparison can be drawn between the unofficial and official Li Bai Poetry Awards:

\footnotetext{
219 'Mianyang jiangjin baiwan she Li Bai Shige Jiang, liang nian yi jie’ 绵阳奖金百万设李白诗歌奖, 两年一届 (Mianyang establishes Li Bai Poetry Award with one-million-yuan award money, accorded every other year), posted on 24 December 2014, https://kknews.cc/other/r9a3lj4.html, accessed 28 September 2019.
} 
1. Entry Qualifications: The NPC awards are solely judged by an individual editor, Yi Sha, selected from his recommended poets within the previous year, while the official award is judged by a committee of referees. Moreover, the official award requires that every entry must be a previously published work in an official literary magazine in mainland China. In the NPC awards, there is only one 'gatekeeper' Yi Sha himself, while in the official award, there are a number of 'gatekeepers' who work collectively, not only the awarding committee, but the numerous editors of the official magazines. The difference is similar to individualism vs collectivism. Though collectivism is more likely to convey the idea of procedural justice and fairness, individualism has its own merit: the sole judge has the greatest freedom to choose the winners he likes and is responsible for every judgement he makes. Thus, the NPC awards bear a stronger aesthetic imprint than most official awards, as it is the reflection of Yi Sha's own concept of good poetry.

2. Aesthetic Standards: The NPC awards represent Yi Sha's personal aesthetic standards and what is good poetry for him, an aesthetics largely based on but not limited by his idea of Colloquial Poetry. In contrast, the official award requires the entries to represent 'core socialist values' 社会主义核心价值观 and promote 'the ideas and spirit of the Reform and Opening as well as the construction of modernisation' 改革开放和现代化建设的思想和精神, spreading the 'main theme' 主旋律 and 'positive energy' 正能量. 220 Judging from their requirements, the difference seems to be personal taste vs state ideology. However, in most official awards, these requirements are only customary routines, for they have to accord with the state ideology on surface. It is more appropriate to judge the nature of an award from its winners and winning works.

3. Winners: The winners of the NPC awards are mostly Yi Sha's friends. However, this does not necessarily mean they are not good poets. Conversely, most friends of 
Yi Sha in the poetry circles are representatives of Colloquial Poetry, such as Shen Haobo and Ma Fei. Moreover, many NPC award winners have seldom or never received any other awards, especially the official awards. In Yi Sha's eyes, the NPC creates an opportunity to recognize those marginalised Colloquial Poets. In the 2015 official Li Bai Poetry Award, the winners include Luo Fu 洛夫, Yu Jian, Xi Chuan, Shen Wei 沈苇, Ouyang Jianghe and Yang Lian 杨炼, all renowned poets of the older generation. This list hardly reflects the award's requirement of 'core socialist values': Luo Fu is a Taiwanese poet in Canada; Yang Lian was once a poet in exile; Yu Jian, Xi Chuan and Ouyang Jianghe are all prestigious avant-garde poets. However, when these famous poets are gathered in a single award, it leaves an impression that the committee just picked the big names rather than making serious judgements.

The NPC project is Yi Sha's most important and influential poetry activity and a manifestation of his unofficial stance vis-à-vis China's official cultural establishment. Over the years, Yi Sha has made great efforts to legitimatise this unofficial project and publicise minjian poetry, with the purpose of making a new canon of twenty-first century Chinese poetry. With such an ambitious project, Yi Sha aims to produce a competing voice against the official poetry institutions and challenge the official aesthetics. The project also reveals his efforts to rewrite the history of contemporary Chinese poetry.

Yi Sha's major poetry activities in the 2010s, all related to the Internet and new digital media, and demonstrated his ongoing efforts to expand and redefine minjian both as a poetic practice and a cultural space. The first decade of the twenty-first century witnessed the rise of poetry websites with online forums, which replaced the former print unofficial magazines as the major venue for the avant-garde poets to publish their work. Yi Sha became an active participant in the Lower Body group's website Poetry Jianghu, a representative online space for the minjian poets. With the decline of the online forum and the rise of Weibo and Wechat, Yi Sha established Chang'an Poetry 
Festival and the 'New Century Classics' project. Both activities used the Internet as an important means of publicity to exert their influence on the Chinese poetry scene. Chang'an Poetry Festival is an institutionalised unofficial poetry organisation, while the New Poetry Classics is a large project composed of online recommendation, print publication and awards, with the purpose of creating the canon of Chinese poetry of the twenty-first century. Through these activities, Yi Sha shows his ambition to institutionalise and canonise minjian poetry to compete with the official institutions and rewrite the literary history. Through the making of minjian, Yi Sha also reinvented himself as a minjian hero. 


\section{Chapter Four Minjian in Global Context: Yi Sha and the World}

No discussion of contemporary Chinese poetry is complete without addressing its intricate relationship with foreign poetry, or more specifically, Western poetry. Likewise, the rise of minjian poetry is not an isolated Chinese phenomenon and must be examined in a broader, global context. During the Panfeng Polemic, the Minjian Poets accused the Intellectual Poets of imitating Western poetry. They thought that the language of the Intellectual Poets was greatly affected by the unidiomatic usage of the Chinese language, in a 'translational style' commonly seen in Chinese translations of Western poetry. Therefore, the Minjian Poets kept emphasizing the importance of colloquialism in poetry, and regarded their own usage of the colloquial as a way of keeping the 'Chineseness' of Chinese poetry. Nevertheless, this accusation against the Intellectual Poets was largely a polemical strategy on the part of the Minjian Poets. As Yi Sha admits, both the Minjian and the Intellectual Poets have been greatly influenced by Western poetry in translation since the $1980 \mathrm{~s}$, but each group chose to be influenced by different sources in western poetry. The Intellectual Poets are mainly influenced by poets like Rainer Maria Rilke, Jorge Luis Borges and Friedrich Hölderlin, while the Minjian Poets prefer Robert Frost, Allen Ginsberg and Charles Bukowski. ${ }^{221}$ Hence, different influences from the West resulted in their divergent poetics.

Although one cannot completely circumvent the issues of influence, the critical assumptions of influence studies, as well as its attendant dichotomies of China/West and local/global, have been increasingly challenged by more fluid and inclusive critical perspectives from recent developments in the studies of Sinophone literatures and world literature. In this chapter, while acknowledging obvious sources of influence, I will present the Minjian Poets not as passive recipients but as proactive agents who interact with the world of poetry beyond China, through translation and being translated,

221 Yi Sha, 'Interview with Liang Yujing', 2016, see Appendix. 
and through publishing overseas in both Chinese and foreign languages. Again, using Yi Sha as a revealing case study, I will explore Yi Sha's multifaceted engagement with Western poetry and how his translational and transnational poetry activities have reshaped the relationship between Chinese poetry and world literature. Taking departure from the 'anxiety of influence' debate, I will argue that Chinese minjian poetry has moved beyond the quagmire of influence and has embraced translatability as a means to communicate minjian poetics to the world.

\section{From Ginsberg to Bukowski: In Search of a Minjian Role Model}

Although the word minjian has implications of nativism, and minjian poetry exhibits some nativist tendencies in its colloquial poetics, the Minjian Poets, or the Colloquial Poets, have not been immune to influences from Western poetry. Chinese poets have been exposed to Western poetry through translation since the 1980 s. To some extent, the development of minjian in Chinese poetry has been inspired by Western influences as much as by its own tradition. Through translations, mistranslations, borrowings and appropriations, Chinese poets turned to their Western counterparts in search of minjian sensibilities, positions, icons, and role models.

The Chinese critic Wang Xiaoming 王晓明 calls the 1980s the 'golden age of text translation' 文字翻译的黄金时期 in mainland China, which witnessed many more translations than in the previous thirty years. ${ }^{222}$ Relative political freedom and the enthusiasm of intellectuals to translate foreign works led to such a golden age of translation. The 1980s, in Yi Sha's words, was a 'barbarous age of copyright' 版权很 野蛮的年代. 223 As China had not established its own copyright law and had not joined

\footnotetext{
222 Wang Xiaoming 王晓明. 'Fanyi de zhengzhi一cong yige cemian kan 80 niandai de fanyi yundong' 翻译的政 治一从一个侧面看 80 年代的翻译运动 (The politics of translation: a perspective to view the translation movement in the 1980s), http://www.guancha.cn/WangXiaoMing/2018 $06 \quad 23 \quad 461091$ 1.shtml, accessed 4 October 2019.

${ }^{223}$ Yi Sha, 'Interview with Liang Yujing', 2016, see Appendix.
} 
any international copyright treaties, many copyright-infringing books of foreign literature were available in the Chinese market. ${ }^{224}$ According to Yi Sha, in the 1980s, foreign poetry was equally accessible to all Chinese poets, including those later known as the Intellectual and Minjian Poets:

The fact is, we were simultaneously influenced by foreign literature, but we were selective in the course of being nourished [...] We all fell on the uncopyrighted literature in translation, reading the same material in the same age, only our taste and selection are different.

实际上就是, 我们同样受到外国文学的影响, 只是我们在受营养的过程中, 已经是很主观地在选择了……其实大家都在扑向没有版权的译进来的作品, 都是在同一个时代里看同样的东西，只不过大家趣味选择不一样。

When talking about foreign influences on the Minjian Poets, Yi Sha mentioned four major poets: Robert Frost (1874-1963), Philip Larkin (1922-1985), Allen Ginsberg (1926-1997) and Charles Bukowski (1920-1994). ${ }^{225}$ Frost and Larkin are important Western influences on the earlier Colloquial Poets like Yu Jian. To Yi Sha and his followers, namely the 'Post-Colloquial Poets', Ginsberg and Bukowski are more important. To some extent, Yi Sha grew into an avant-garde Minjian Poet mainly under the influence of Ginsberg and Bukowski. To Yi Sha, Ginsberg was a poetic idol in his youth; while Bukowski is the spiritual companion he finds in poetry.

Though the first collection of Allen Ginsberg's work in Chinese translation was published in 1991 (translated by Zhang Shaoxiong 张少雄), some of his representative poems, like Howl, have been available in Chinese since 1981, through translators like Zhao Yifan 赵一凡 and Zhao Yiheng 赵毅衡. ${ }^{226}$ As the leading poet of the Beat

\footnotetext{
224 This chaotic state of copyright lasted until 1992, when China joined the Berne Convention and the Universal Copyright Convention.

225 Ibid.

${ }^{226}$ For Zhang Shaoxiong's book, see Allen Ginsberg 金斯伯格. Kadixu一muqin wange 卡第绪——亲挽歌
} 
Generation, Ginsberg visited China with a delegation of American writers in 1984. With the delegation, he met Chinese writers and read poetry in Beijing, Shanghai, Suzhou and Xi'an. After the other members of the delegation left China, he stayed on in China by himself. He went to Baoding and taught at Hebei University for a month. ${ }^{227}$ Though there is no evidence that Ginsberg met any Colloquial Poets in person during his stay in China, these translations and activities made him a household name on the Chinese poetry scene of the 1980 s.

In every respect, Ginsberg has some characteristics akin to that of a Chinese minjian poet. On the one hand, Ginsberg is a master of colloquialism, who uses the oral language, the vernacular and slang as a literary language, following a trend to write as people speak, that is a return to orality. As a great performer of poetry, Ginsberg fused Jazz musicality and rhythms in his poetry; his poems gained a better effect on stage than on paper. His Howl is such a text, combined as it is with all kinds of colloquial elements: slang vocabulary, broken sentences, additivity, redundancy, nonlinearity, spontaneity and immediacy. On the other hand, Ginsberg looked very 'unofficial' by the Chinese standard, especially in his early years as a Beatnik in the 1950s. As the leading poet of the Beat Generation, Ginsberg's way of life, such as his vagrancy, drug use and homosexuality, appeared quite unconventional to the Chinese mind in the 1980s. The obscenity trial of Howl in 1957 also brought fame to the poet as a rebellious hero. In addition, Ginsberg's persistent criticism of the American government leaves an impression with the reader that he was not in line with the 'official'. All these elements made Ginsberg a poetic icon in the eyes of most Minjian Poets, including the young Yi Sha.

(Kaddish: an elegy for his mother), trans. Zhang Shaoxiong 张少雄. Guangzhou: Huacheng chubanshe, 1991. This book includes 24 poems by Allen Ginsberg. For Zhao Yifan's and Zhao Yiheng's translations, see Allen Ginsberg 阿伦·金斯伯格. 'Haojiao' 嚎叫 (Howl), trans. Zhao Yifan 赵一凡 and “'Kuadiao de yidai” duanshi xuan' “垮掉 的一代”短诗选 (Selected short poems of the Beat Generation), trans. Zhao Yiheng 赵毅衡. Dangdai waiguo wenxue 当代外国文学 (Contemporary Foreign Literature), No. 3, 1981, pp. 153-60. All these translators translate Ginsberg as Jinsiboge 金斯伯格. However, Ginsberg has also been widely known as Jinsibao 金斯堡 in China.

227 Zhang Jian 张剑. 'Jinsibao, Haojiao yu kangyi wenhua' 金斯堡、《嚎叫》与抗议文化 (Ginsberg, Howl and the culture of protest), http://epaper.gmw.cn/zhdsb/html/2012-08/08/nw.D110000zhdsb 20120808 1-17.htm, accessed 7 October 2019. 
Yi Sha was dubbed 'China’s Ginsberg' 中国的金斯堡 in his early career ${ }^{228}$, but the two bear little resemblance upon closer examination. Ginsberg is a multifaceted figure: Beat Poet, political activist, drug user, philosopher, Zen-Buddhist, of Jewish heritage and gay. However, in the eyes of many Chinese Minjian Poets, Ginsberg is largely an avant-garde poet who courageously writes about taboo themes, such as sex and homosexuality, with frank colloquialism, while other elements of Ginsberg's poetry are seldom discussed by Chinese poets. This impression of Ginsberg is at the very least only a partial, if not a complete, misunderstanding. Yi Sha's nickname 'China's Ginsberg' mainly refers to Yi Sha's courage to take the risk of writing about taboo themes with taboo language: it is praise for Yi Sha's audacity in writing that has little to do with other characteristics of Ginsberg, such as political views and homosexuality.

Since Yi Sha encountered Charles Bukowski's poetry in 1994, he has gradually noticed the poetic divergence between Ginsberg and himself. In my interview with Yi Sha, he explained as follows:

... I think, in my puberty, I had no problem with Ginsberg, who was my first icon. However, later he became estranged from me and suddenly turned into one unrelated to me. First, I dislike long sentences; second, I dislike parallelism. Both are his characteristics. Third, I dislike sentences with a lyrical atmosphere, but in fact he is quite lyrical.

·我就觉得，金斯堡在我的青春期是没问题，第一偶像。但是到后来，应 该说跟我的疏远非常大, 就是一下变成了个跟我没关系的诗人了。一个是我 不喜欢长句子，一个是我不喜欢排比句，这都是他的表征。还有一个，我不 喜欢抒情气氛太浓的句子，实际上他的抒情气氛相当浓。229

\footnotetext{
228 This nickname was given by a Chinese American, Liu Yaozhong 刘耀中, but later it became widely known in the Chinese poetry circles. Yi Sha, 'Interview with Liang Yujing', 2016, see Appendix.

229 Yi Sha, 'Interview with Liang Yujing', 2016, see Appendix.
} 
Here, 'puberty' refers to the early period of Yi Sha's writing career rather than his adolescent years. In American poetry, Ginsberg is, to a large extent, the reincarnation of Walt Whitman in the twentieth century, with his passionate, endless long sentences in parallelism, which are completely different from Yi Sha's plain, simplistic and minimal style. Therefore, when Yi Sha, 'China's Ginsberg', got the chance to read Charles Bukowski, he immediately found this was the western poet most akin to himself, both in poetry and temperament.

Bukowski, called by TIME magazine in 1986 the 'laureate of American lowlife', ${ }^{230}$ has more typical minjian characteristics. Firstly, though both Ginsberg and Bukowski write poetry in colloquialism, their styles are totally different. In Yi Sha's words, Ginsberg's poetry is 'a great manifesto to the world' 对世界的大宣言, while Bukowski's writing exhibits his real life, filled with sex, alcohol abuse, and violence. ${ }^{231}$ For Yi Sha, Bukowski is 'on a higher level', ${ }^{232}$ for Bukowski's poetry deals with his everyday experiences, presenting his life rather than making any announcements.

Secondly, on the institutional level, Bukowski, the king of the underground rather than the leader of an influential countercultural movement, looks more 'unofficial' than Ginsberg in the eyes of Yi Sha. Though Ginsberg appeared as a controversial, rebellious figure in the $1950 \mathrm{~s}$, he was gradually accepted by the mainstream in his later life. He won the National Book Award for Poetry in 1974 and was inducted into the American Academy of Arts and Letters in 1979. However, Bukowski remained an outsider of the mainstream literary circles all through his life. Only after his death, has his poetry gained wide popularity and he has become the subject of numerous critical articles and books, such as Andrew J. Madigan's 'What Fame Is: Bukowski's Exploration of Self', Giovanni Di Stefano's 'Meaningfulness and Meaninglessness of Work in Charles

\footnotetext{
230 Pico Iyer. 'Celebrities Who Travel Well'. TIME, 16 June 1986. http://content.time.com/time/subscriber/article/0,33009,961603-1,00.html, accessed 9 October 2019.

231 Yi Sha, 'Interview with Liang Yujing', 2016, see Appendix.

232 Ibid.
} 
Bukowski' and Abel Debritto's Charles Bukowski, King of the Underground: From Obscurity to Literary Icon.

Two factors have played important roles in Bukowski's road from obscurity to fame: little magazines and German translations, which are similar to Yi Sha's publication in the Chinese unofficial magazines and overseas. Little magazines, in contrast with academic quarterlies, are usually independent, small-scale, cheaply made literary magazines. The publication of Bukowski's works mainly benefited from the Mimeo Revolution of the 1960s and 1970s, a period that witnessed a large number of mimeo little magazines and presses. Bukowski, largely rejected by academic quarterlies, found an outlet for his works through these little magazines. As Abel Debritto states, 'Charles Bukowski was a product of the small press movement, an unparalleled phenomenon in the so-called little magazines that proliferated in the United States during the 1960s. His long journey through the 'littles' and the small presses was finally rewarded after many a bitter battle in the back alleys of the American literary scene.' ${ }^{233}$ The other factor, Carl Weissner's German translation, brought Bukowski extraordinary fame in Europe, particularly in his birthplace, Germany, before he received attention from academic critics in America. Considering these factors, it is quite understandable that Yi Sha took great interest in Bukowski and saw him as a literary icon.

When Yi Sha first encountered Bukowski's poetry in 1995, Bukowski was almost unknown in China. The person who introduced him to Bukowski is a Chinese American named Liu Yaozhong 刘耀中, who, according to Yi Sha, was an immigrant with a technical background, but keen on writing articles in Chinese about American philosophers and writers for Chinese newspapers overseas. ${ }^{234}$ Liu got to know Yi Sha's poetry through the New York-based Chinese magazine Yihang 一行 (A line) and began to correspond with Yi Sha in the early 1990s. It was Liu who called Yi Sha

\footnotetext{
233 Abel Debritto. Charles Bukowski, King of the Underground: From Obscurity to Literary Icon. New York: Palgrave Macmillan, 2013, p. 1.

234 Yi Sha, 'Interview with Liang Yujing', 2016, see Appendix.
} 
'China's Ginsberg' in one of his letters. In 1995, one year after Bukowski's death, Liu sent Yi Sha an article on Bukowski, which made him interested and excited. After reading the article, Yi Sha knew by instinct that 'this was a poet destined to have something to do with me' 这是一位注定要和我有点关系的诗人. ${ }^{235} \mathrm{Then}$, on Yi Sha's request, Liu sent him a poetry collection by Bukowski, Play the Piano Drunk Like a Percussion Instrument Until the Fingers Begin to Bleed a Bit. Yi Sha's wife, Lao G, who was better than Yi Sha in reading English, read the book and told him 'he [Bukowski] writes your kind of poetry’ 他写你这种诗. ${ }^{236}$ At Yi Sha's suggestion, the couple then translated 24 of Bukowski's poems in July and August 1995. Thus, they became the first translators in mainland China of Bukowski's poetry. ${ }^{237}$

Of the 24 poems they translated in 1995, 23 were subsequently published in a dozen magazines in China and abroad. After a long hiatus due to the birth of their son, Yi Sha and Lao G collaborated again in 2002 and translated another 76 of Bukowski's poems. By then they had translated a total of 100 poems by Charles Bukowski. Although, due to copyright issues, these translations have yet to officially appear in book form, their efforts have played an instrumental role in establishing the reputation of Charles Bukowski within Chinese avant-garde poetry circles. Their first book-length publication of Bukowski, Bei kao jiutong 背靠酒桶 (Leaning against the barrel), appeared in 2011, an unofficial publication without a ISBN. In 2012, they produced two more volumes of Bukowski’s poetry, Jipin 极品 (The finest of the breed) and Ganjing laotou 干净老头 (A clean old man), also unofficially published. ${ }^{238}$

\footnotetext{
235 Yi Sha 伊沙. 'Daidao taiyang dengbuji le, women cai nufang—Bukaosiji yishi xiaoji' 待到太阳等不及了, 我 们才怒放——布考斯基译史小记 (We did not bloom until the sun disgusts with waiting: a brief note on our history of translating Bukowski). Charles Bukowski 查尔斯 - 布考斯基. Ganjing laotou: Bukaosiji shixuan 干净老头: 布考斯基诗选 (A clean old man: selected poems of Charles Bukowski), trans. Yi Sha 伊沙 and Lao G 老 G. Unofficial publication, 2012, p. 195.

${ }^{236}$ Ibid, p. 195.

${ }^{237}$ Lao G's real name is Ge Mingxia 葛明霞, also a graduate from Beijing Normal University.

238 In 2019, Xiron eventually got the permission from the copyright owner HarperCollins to publish Charles Bukowski's poetry in Chinese. A volume of Bukowski in Yi Sha and Lao G's translation, with ISBN, is forthcoming in late 2019.
} 
Yi Sha's translation of Bukowski, in collaboration with Lao G, was a labour of love. It was a voluntary activity which Yi Sha initiated from the early period of his writing career, without knowing whether their translations could be published. This voluntary choice shows the significance of Bukowski to Yi Sha and the innate affinity between the two poets. No doubt, Bukowski's life and poetry attracted and found an echo with Yi Sha, who saw Bukowski as his counterpart and literary icon. Yi Sha's first collection, Starve the poets, was published the year before and had received mixed critical response. Under such circumstances, Yi Sha was thrilled to find a contemporary American poet who was writing in an anti-lyrical, colloquial and down-to-earth style that was similar to his own work, and this gave him both inspiration and encouragement. Apart from Bukowski's poetry, his legendary experiences of being long rejected by the literary mainstream and his rise to fame as a 'laureate of American lowlife' in his later years, were also fascinating to the young Yi Sha, who himself had experienced three years of being rejected by mainland literary magazines before publishing his first collection in 1994. In short, he regarded Bukowski as his model in the English-speaking world and strove to introduce him to a Chinese audience.

In the case of Yi Sha and Lao G's translation of Bukowski, the minjian elements were not only represented in their discovery of an American poet who writes in the vein of Colloquial Poetry, but also in the unofficial publication of their translations. As aforementioned, they did not have the copyright holder's permission to officially publish their translations of Bukowski, and thus, their translations, except for occasional appearances in official magazines, were mainly published first in unofficial magazines in the 1990s and then in online venues such as poetry forums, that had become popular among poets in the 2010s. They did not publish their translations in book form until 2011. All of the three books they published were unofficial publications without an ISBN and therefore could not be sold through the normal channels, such as in bookshops. Readers, mostly the minjian poets themselves, could only purchase the books directly from the translators. Although these books of translation with a limited, 
unofficial circulation failed to reach a larger audience, they did make Bukowski a popular name within the avant-garde poetry circles.

Yi Sha's extolment of Bukowski is persistent and omnipresent, especially in his social media like Weibo and Wechat. One of his Bukowski collections was entitled A clean old man, an allusion to Bukowski's Notes of a Dirty Old Man - the change from 'dirty' to 'clean' shows his effort to elevate Bukowski's image from a 'badass' poet to a nobleminded literary master. In his translator's afterword to A clean old man, Yi Sha made a brief comparison between the two poets who influenced him most: Ginsberg is 'an epic writer, a spokesman for his age “史诗”书写者、时代的代言人, but he is weaker in his short poems, whereas Bukowski is a master of short poems, standing for the everyday, the marginal and the individual. Ginsberg writes the 'real intellectual poetry' 真正知识分子的诗歌 while Bukowski is a representative of "populism and individualism' 平民主义和个人主义. ${ }^{239}$ Yi Sha also emphasizes that by 'intellectual' he means the original meaning of the word rather than its distorted meaning on the Chinese poetry scene. He uses this word in its positive meaning rather than that of the Chinese Intellectual Poetry 中国知识分子诗歌, of which he disapproves. ${ }^{240}$ In my interview with Yi Sha, he explained that he understands 'intellectual' as 'a critical spirit' and 'a challenging spirit', rather than an elitist taste. ${ }^{241}$ At that point, his preference for Bukowski was apparent in his conclusion of his comparison. Later, in my 2016 interview, Yi Sha admitted that, since the appearance of Bukowski, he had a growing dislike for Ginsberg, because the latter tended to use long sentences and make manifestos in poetry.

Under Yi Sha's influence, a number of minjian poets, such as Xu Jiang, Shen Haobo and many younger ones, all list Bukowski as one of their literary icons. For example, in a 2002 article, Shen Haobo criticised the phenomenon of the young avant-garde poets

\footnotetext{
239 Ibid, p. 200-201.

240 Ibid.

241 Yi Sha, 'Interview with Liang Yujing', 2016, see Appendix.
} 
who blindly imitated Bukowski both in their writing and lifestyle. His words, however, reveal the popularity of Bukowski on the Chinese poetry scene, 'As more and more poems of Bukowski are translated, he has become a new icon among the avant-garde poets ... like any other literary icons, Bukowski brought to Chinese poetry not only aesthetic specimens purer and more mature but also great adverse effects' ${ }^{242}$ Shen's criticism was aimed at the imitative Chinese poets rather than at Bukowski. On the contrary, he also sees Bukowski as one of his idols. In a poem 'My Heroes' 我的英雄, Shen lists Bukowski as one of his four heroes, along with Xuanzang 玄牀, Lu Xun 鲁 迅 and Mahatma Gandhi. ${ }^{243}$

Though Yi Sha and Lao G were the first to translate Bukowski in China and were the major contributors to Bukowski's reputation among Chinese poets, the official publication of their translations was delayed once and again due to copyright problems until 2019, when Shen Haobo's Xiron got the permission to publish Bukowski. In 2017, the first copyright-sanctioned collection of Bukowski's poetry, Ai shi diyu mingquan 爱是地狱冥犬 (Love Is a Dog from Hell, trans. Xu Chungang 徐淳刚), was published in China. The Chinese title is in a higher register than the English original, for mingquan 冥犬 gives an impression of some supernatural creature like Cerberus in Greek mythology rather than Bukowski's plain and colloquial expression 'a dog from hell'. Xu also published a collection of Bukowski’s poetry, Sheng lai ruci 生来如此 (Born Into This), unofficially in 2013 with an independent publisher, Black Whistle 黑哨诗 歌. ${ }^{244}$ Both translators, Yi Sha and Xu Chungang, followed the same path in publishing

\footnotetext{
${ }^{242}$ Shen Haobo 沈浩波. 'Dangdai Zhongguo shige zhong de sizhong xurongxin' 当代中国诗歌中的四种虚荣心 (Four types of vanities in contemporary Chinese poetry). Shen Haobo 沈浩波. Mingling wo chenmo 命令我沉默 (Command me to be silent). Hangzhou: Zhejiang wenyi chubanshe, 2013, pp. 7-8.

243 Shen Haobo 沈浩波. 'Wo de yingxiong' 我的英雄 (My heroes). Shen Haobo's weibo: https://www.weibo.com/p/2304185951573c0102x9n8?mod=zwenzhang, accessed 25 May 2019.

${ }^{244}$ Black Whistle 黑哨诗歌 was founded in 2008 by poet and artist, Fang Xianhai 方闲海, and is devoted to publishing avant-garde poetry. In China, such publishers are known as 'independent publishers' 独立出版社. However, most of them do not really 'publish' books but make books and sell these by themselves, for they cannot get an ISBN for their books. 'Independent publishing' is not equal to 'unofficial publishing'. Some independent publishers can still publish their books officially while most of them cannot.
} 
their translations of Bukowski, from independent publishing or self-publishing to an official publisher, a trajectory that somewhat paralleled Bukowski's fate of rising to fame from the underground in the English-speaking world.

To discuss Bukowski's poetry in Chinese translation, censorship is a factor that must be taken into consideration, and hence unofficial publications are usually more reliable than officially published versions. To be censored means to be published officially and thus to gain a larger audience, but doing so will result in damage to the aesthetic wholeness. $^{245}$ It is a seeming dilemma, yet Yi Sha resolved the problem by publishing his translations in both ways. Unofficial publications played a vital role in spreading Bukowski's poetry in China. Here is one of Bukowski's poems followed by the translation by Yi Sha and Lao G, from their unofficially published $A$ clean old man:

\section{blue moon, oh bleweeww mooooon how I adore you!}

I care for you, darling, I love you,

the only reason I fucked L. is because you fucked

Z. and then I fucked R. and you fucked N.

and because you fucked N. I had to fuck

Y. But I think of you constantly, I feel you

here in my belly like a baby, love I'd call it,

no matter what happens I'd call it love, and so

you fucked C. and then before I could move

you fucked W., so then I had to fuck D. But

I want you to know that I love you, I think of you

constantly, I don't think I’ve ever loved anybody

\footnotetext{
245 According to Shen Haobo, a publishing tycoon and Minjian Poet, censorship is a very tricky problem in China, for there are no written regulations or standards for censorship telling what cannot be published. All depends on the judgements of the publishers themselves, thus it is rather self-censorship, and the standards vary from time to time, based on the publisher's experience. However, the publisher will be punished if the authorities find a book problematic after it comes out.
} 
like I love you.

bow wow bow wow wow

bow wow bow wow wow. ${ }^{246}$

\section{蓝月亮，噢，蓝蓝蓝蓝月亮，我是多么爱慕你！}

我在乎你，亲爱的，我爱你

我操 $\mathrm{L}$ 惟一的理由是因为你操了

$\mathrm{Z}$ ，然后我操 $\mathrm{R}$, 你操 $\mathrm{N}$

因为你操 $\mathrm{N}$, 我不得不操

Y，可我不住地想你，我感觉你

在此像个胎儿在我腹中，我称之为爱情

不管发生什么事，我都称之为爱情，如此

你操 $\mathrm{C}$, 然后, 在我行动之前

你操 $\mathrm{W}$, 然后我不得不操 $\mathrm{D}$, 但是

我要你知道我爱你, 我不住地

想你，我不认为我曾经爱过任何人

像我爱你一样

\section{汪汪汪汪汪}

汪汪汪汪汪 $^{247}$

In general, such a poem is unpublishable in official paper-based publications. ${ }^{248}$ Since

\footnotetext{
246 Charles Bukowski. Play the Piano Drunk Like a Percussion Instrument Until the Fingers Begin to Bleed a Bit. Santa Rosa, CA: Black Sparrow Press, 1979, p. 81.

${ }^{247}$ Charles Bukowski 查尔斯 ・布考斯基. Ganjing laotou: Bukaosiji shixuan 干净老头: 布考斯基诗选 (Aclean old man: selected poems of Charles Bukowski), trans. Yi Sha 伊沙 and Lao G 老 G. Unofficial publication, 2012, p. 160 .

248 I published my translation of American poet Kim Addonizio's poetry in China in 2019. The publisher asked me to remove all references to sexual organs, drugs and swear words from that book, or else the book could not be published. For example, cao 操 (fuck) is a no-no in official publication.
} 
much of the poetic effect of this poem depends on the repeated use of the word 'fuck', Yi Sha, as the translator, had to use the Chinese equivalent, cao 操, to keep the succinct, colloquial characteristic of the original. In China, official print publications have zero tolerance for the word cao. Fortunately, Yi Sha was able to make it available to the reader through unofficial print publications and the Internet. There is still censorship in both of these venues, but they are generally spaces with more freedom than official print publications.

Admittedly, Yi Sha is a better poet than a translator. His translations, albeit often full of brilliant ideas, are not free from errors, misreadings and mistranslations. However, Yi Sha's imperfect translations of Bukowski have opened up new possibilities for Chinese poetry and extended the influence of minjian poetry. Below is a poem from The finest of the breed:

\section{The Finest of the Breed}

there's nothing to

discuss

there's nothing to

remember

there's nothing to

forget

it's sad

and

it's not

sad

seems the

most sensible 
thing

a person can

do

is

sit

with drink in

hand

as the walls

wave

their goodbye

smiles

one comes through

it

all

with a certain

amount of

efficiency and

bravery

then

leaves

some accept

the possibility of

God

to help them

get

through

others 
take it

straight on

and to these

I drink

tonight. ${ }^{249}$

\section{极品}

惟有虚无

可供讨论

惟有虚无

可资记忆

惟有虚无

可以忘却

它是悲哀

却

又

不是悲哀

似乎是

最有感的

事

一人

可做

249 Charles Bukowski. You Get So Alone at Times That It Just Makes Sense. Santa Rosa, CA: Black Sparrow Press, 1986, pp. 131-32. 
便是

独坐

与酒同在

酒杯在手

当四壁

摇晃

墙说再见

微笑

一人来了

穿墙而过

完全彻底

用

气功

和

勇敢

然后

离去

一些人接受

上帝存在的

可能性

帮助他们

得以

穿越

其它

怀抱上帝

一路向前 


\section{面对这些}

\section{我独饮}

在今宵。250

As I have noted, Yi Sha's translations contain inaccuracies. This particular translation is a case in point, full of mistakes and misunderstandings. From Stanza Three to Six, the meaning of the original is in large part misunderstood. Bukowski depicts three types of persons: 'one' who comes through with 'efficiency' and 'bravery', 'some' who accept the 'possibility of God' and 'others' who 'take it straight on'. However, in Yi Sha's translation, these three types are mixed up and thus confusing. There are obvious mistakes such as his translations of 'it', 'sensible' and 'efficiency'. There is also a misunderstanding of the sentence structure in Stanza Three (most sensible / thing / a person can / do). It seems that Yi Sha does not dare make great changes to the sentence structure to get a more fluent result in Chinese for fear of changing the meaning of the original, thus the four stanzas in the middle (Three, Four, Five and Six) look rather awkward.

Though strewn with mistakes, Yi Sha's translation is faithful in keeping Bukowski's temperament, together with occasional bursts of brilliance. Translating Bukowski is not very difficult in terms of language, for he writes in a simple and straightforward style. However, it is not easy to retain his gritty temperament with the economy of words. In this regard, Yi Sha did well. The title jipin 极品, which becomes the title of the collection, is an unexpected encounter that shows Yi Sha's originality and creativity, for jipin, a literal translation of Bukowski's title, is a strong, impressive colloquialism in contemporary Chinese. Moreover, the word can mean both the best and, ironically, the weirdest. When used as the book title, it indicates that Bukowski is both the best

\footnotetext{
250 Charles Bukowski 查尔斯 • 布考斯基. Jipin: Bukaosiji Shixuan 极品: 布考斯基诗选 (The Finest of the Breed: Selected Poems of Charles Bukowski), trans. Yi Sha 伊沙 and Lao G 老 G. Self-published, 2012, pp. 133-35.
} 
and the weirdest, thus it is a very effective pun.

Yi Sha's translations of Charles Bukowski form an important extension of his minjian poetics, not only because of the aesthetic affinity between Bukowski's poetry and his own, but also because Bukowski's cultural irreverence reinforces the unofficial stance that Yi Sha cultivates. Yi Sha's endeavour to introduce Bukowski to contemporary Chinese poetry, mostly through unofficial channels, brings his minjian practice to bear upon the field of translation. Such efforts created an American role model for the Chinese minjian poets. Perhaps more importantly, the Bukowski translations gave voice to Yi Sha as a translator and allowed him to reshape the Chinese reception of the Western canon from a minjian standpoint.-

\section{From Bukowski to Tagore: Extending the Minjian Canon through Translation}

After many years of translating Bukowski, Yi Sha and Lao G drew the attention of publishers and began to receive commissioned translation work. They co-translated Tagore's Stray Birds, The Crescent Moon and Gitanjali from English, and published them as a single volume under the title Sheng ru xiahua, si ru qiuye 生如夏花, 死如 秋叶 (Let life be beautiful like summer flowers and death like autumn leaves) through the Jiangsu Literature and Art Publishing House 江苏文艺出版社 in 2013. The three Tagore translations were then published as three separate volumes by Shen Haobo in 2017, under Xiron Poetry Club 磨铁读诗会, an imprint that specialised in publishing poetry and poetry in translation. In 2018, Xiron Poetry Club reissued an earlier publication of Yi Sha and Lao G's translation of Anna Akhmatova (from an English translation), under the title Wo zhidao zenyang qu ai: Ahematuowa shige jingxuan ji 我 知道怎样去爱：阿赫玛托娃诗歌精选集 (I know how to love: best poems of Anna Akhmatova). 
Ma Fei 马非, Yi Sha's fellow poet and the editor-in-chief at Qinghai People's Press 青 海人民出版社, commissioned the couple to produce three books of translation, including two poetry anthologies, Dang ni lao le: Shijie mingshi 100 shou xinyi 当你 老了: 世界名诗 100 首新译 (When you are old: new translations of 100 famous foreign poems, 2013) and Laizi shijian de dahai: Ying Mei mingshi 100 shou xinyi 来 自时间的大海：英美名诗 100 首新译 (From the oceans of time: new translations of 100 famous British and American poems, 2014), as well as Shashibiya shisihangshi 莎 士比亚十四行诗 (Sonnets of William Shakespeare, 2014).

For commissioned work, the selection of authors to translate was the result of negotiation between Yi Sha and the publishers. Nonetheless, some publishers, such as Ma Fei and Shen Haobo, were also Yi Sha's friends and fellow minjian poets, who shared similar tastes in aesthetics and poetics. Their selection of authors was not merely commercial but with ample aesthetic consideration. One common reason why they chose Tagore, Akhmatova and Shakespeare was that while these are all well-known foreign poets in China, Yi Sha and his fellow minjian poets were not satisfied with the current translations, having determined that the immature language of the earlier translators damaged the aesthetic value of the originals. Thus, they intended to retranslate those classical poets to restore their poetic beauty in modern vernacular Chinese. From this perspective, these translations can be seen as a part of Yi Sha's ambition to challenge the literary establishment and reshape the canon of modern Chinese poetry with his own aesthetics, in his own language.

Yi Sha's retranslation of Tagore is a telling example of this ambition. As the first Asian Nobel laureate in literature, Tagore has been made a household name in China through the efforts of such notable translators as Zheng Zhenduo 郑振铎 and Bing Xin 冰心. Zheng Zhenduo published his translations of Stray Birds 飞鸟集 (1922) and The Crescent Moon 新月集 (1923) and Bing Xin translated Gitanjali 吉檀迦利 (1955) and The Gardener 园丁集 (1961). Over years, there have appeared numerous new translations of Tagore, which have made him one of the most translated foreign poets 
in China. After Yi Sha's translation in 2013, Feng Tang 冯唐 published his version of Stray Birds 飞鸟集 in 2015, arguably the most controversial version of Tagore, in which he translated many poems as erotic ones with vulgar expressions and thereby aroused wide disputes in literary circles. Due to the obvious unreliability of Feng Tang's translation, his publisher had to recall all of the copies from the market at the end of 2015.

In a report by Xi'an ribao 西安日报 (Xi'an daily), Yi Sha criticises Feng Tang's translation as a 'farce' 闹剧 and 'a blasphemy against poetry' 对诗的裚渎. ${ }^{251}$ In another report in the Kunming-based Dushi shibao 都市时报 (Capital times), Yi Sha says that 'both Bing Xin and Zheng Zhenduo feminised and soften Tagore' 冰心和郑 振铎都不约而同地把泰戈尔的诗歌女性化、软化了 and cites an anonymous poet's comment that Yi Sha's Tagore 'has beard' 长胡子. ${ }^{252}$ Yi Sha's attitude towards Bing Xin's and Zheng Zhenduo's translations reveals part of his purpose on translating Tagore: he intended to provide a masculine version of Tagore's poetry, for he, together with several other minjian poets, had a belief that Bing Xin and Zheng Zhenduo wrote in an immature vernacular Chinese and poetic style that damaged the poetic value of Tagore's work. As a contemporary Colloquial Poet, it is his responsibility to correct this misunderstanding. A couple of comparisons between Zheng Zhenduo's and Yi Sha's translations of Stray Birds can illustrate the characteristics of Yi Sha's translation in terms of language:

\footnotetext{
251 'Wenxue fanyi shi yao zhongyu yuanwen haishi suixing chuangzuo' 文学翻译是要忠于原文还是随性创作 (Literary translation: faithful to the original or free creation?). Xi'an ribao 西安日报 (Xi'an daily), http://epaper.xiancn.com/xarb/html/2016-01/06/content_405783.htm, accessed 20 May, 2019.

252 ‘Chongyi Taige’er shiji yin zhengyi: shiren Yi Sha dongle shui de “chulian”?’ 重译泰戈尔诗集引争议: 诗人 伊沙动了谁的 “初恋” ? (Dispute caused by retranslating Tagore: whose first love has poet Yi Sha touched?). Dushi shibao 都市时报 (Capital times), http://blog.sina.com.cn/s/blog_489db0970102eaph.html, accessed 20 May, 2019.
} 
Stray birds of summer come to my window to sing and fly away. And yellow leaves of autumn, which have no songs, flutter and fall there with a sigh. ${ }^{253}$

夏天的飞鸟, 飞到我的窗前唱歌, 又飞去了。
秋天的黄叶, 它们没有什么可唱, 只叹息一声, 飞落在那里。

(trans. Zheng Zhenduo)

夏日迷失的鸟群, 来到我窗前, 歌唱, 然后飞走。

秋天枯黄的叶子，无歌，一声叹息，在此飘落。 254

(trans. Yi Sha \& Lao G)

Yi Sha strives to be faithful in his translation but sometimes he is too cautious to be faithful. The plural 'birds' does not necessarily mean a flock of birds 鸟群, but more appropriately several of them, as 'stray' implies. The problem of inaccuracy always exists in Yi Sha's translation, which, however, is not the focus of my discussion here. The characteristic of Yi Sha's translation lies in the language style he uses, not completely colloquial but more likely a refined colloquial language, which makes his Tagore more solemn and masculine than Zheng's translation. This distinction is more obvious in translating the later part of the second line. Zheng's translation, colloquial enough, looks a bit verbose especially in 'which have no songs’ 没有什么可唱. Yi Sha uses a more formal but still lucid phrase 无歌 to gain a stronger effect and better rhythm, and the following 'flutter and fall there with a sigh'一声叹息, 在此飘落 is also a more succinct rendition. In a nutshell, Yi Sha's choice of this language style is not contradictory to his poetics of the Colloquial Poetry, but rather an embodiment of his belief that his Colloquial Poetry, not merely colloquialised poetry, but requires refinement of colloquialism. Another instance in Stray Birds:

\footnotetext{
253 Rabindranath Tagore. Stray Birds. Radford: Wilder Publications, 2009, p. 4.

${ }^{254}$ Rabindranath Tagore 泰戈尔. Sheng ru xiahua, si ru qiuye: Taige'er mingshi jingxuan 生如夏花, 死如秋 叶: 泰戈尔名诗精选 (Let life be beautiful like summer flowers and death like autumn leaves: selected poems of Rabindranath Tagore), trans. Yi Sha 伊沙 and Lao G 老 G. Nanjing: Jiangsu wenyi chubanshe, 2013, p. 2.
} 
Listen, my heart, to the whispers of the world with which it makes love to you. ${ }^{255}$ 静静地听, 我的心呀, 听那世界的低语, 这是它对你求爱的表示呀。 (trans. Zheng Zhenduo)

我的心，快听，大地对你示爱的低语。256

(trans. Yi Sha \& Lao G)

It is questionable for Yi Sha to translate 'the world' as 'earth' 大地 instead of 世界 but this case showcases how Yi Sha makes Tagore masculine - he abandons nearly all the modal particles in Zheng's translation such as ya 呀, which is widely used in the works of the poets in the first half of the twentieth century but sounds a little childish and feminine to the contemporary ear. The only modal particle Yi Sha retains is 'o' 哦, a deeper sound for translating the occasional ' $\mathrm{O}$ ' in the English version of Tagore. In this line, Yi Sha gets rid of the redundant 'quietly' 静静地 in Zheng's translation and simplifies the syntactic structure a little bit by converting the clause "with which it makes love to you' into an adjective 示爱的, thus making the full sentence shorter and stronger, no longer as soft as Zheng's translation.

The two cases above in translating Stray Birds are good illustrations to show Yi Sha's idea of the poetic language — not only colloquial but refined. By 'colloquial' he intends to avoid the complex, obscure rhetoric and by 'refined' he strives to abandon the verbose expressions in everyday language, which is the ultimate goal for his PostColloquial Poetry on the language level. In this sense, Yi Sha's translations of Tagore,

255 Rabindranath Tagore. Stray Birds. Radford, VA: Wilder Publications, 2009, p. 6.

256 Rabindranath Tagore 泰戈尔. Sheng ruxiahua, si ru qiuye: Taige'er mingshi jingxuan 生如夏花, 死如秋叶: 泰戈尔名诗精选 (Let life be beautiful like summer flowers and death like autumn leaves: selected poems of Rabindranath Tagore), trans. Yi Sha 伊沙 and Lao G 老 G. Nanjing: Jiangsu wenyi chubanshe, 2013, p. 5. 
as well as his translations of Akhmatova and Shakespeare, demonstrate his attempt to provide a language mode for the Post-Colloquial Poetry and find new audiences for this style of language. Through retranslating and remoulding foreign classics with the language and sensibilities Post-Colloquial Poetry, Yi Sha embarks on an ambitious project of rewriting the cannon of world poetry with Chinese minjian characteristics.

\section{Yi Sha's Poetry Overseas: Chinese Minjian made in Australia}

While actively consolidating and expanding his minjian canon by incorporating key figures of world poetry through translation, Yi Sha puts equal emphasis on exporting his minjian poetry through various avenues of publication and publicity overseas. Contemporary Chinese poetry is typically introduced to the international reader through two major channels: translation and international poetry festivals. In most cases, the two channels are closely related to each other, as one leads to the other. Chinese minjian poetry more or less follows these trajectories as it travels overseas. For the minjian poets who feel somewhat marginalised within the Chinese official poetry circles, being translated and published overseas also gives them a sense of legitimatization and a confirmation of their poethood.

For minjian and other Chinese avant-garde poets, a less visible form of international recognition, as well as a means of survival, is to have their work published overseas, not in translation, but in Chinese. Apart from English translations, Yi Sha has also published his poetry overseas in Chinese. Tang stands out in Yi Sha's poetry books due to its unusual 'unofficial' form of publication, as it was published outside China but still

in Chinese, by Otherland in Melbourne. In the following section, I will focus on exploring why this method of publication was adopted and what this publication tells us about the global dimensions of Yi Sha's poetry and of the production and circulation of Chinese minjian poetry in general. 
The tortuous route that led to the publication of Tang in Australia involved the sustained efforts of two key figures: the Australia-based publisher Ouyang Yu and the Chinabased editor Zhong Dao 中岛. Ouyang Yu, a Chinese-Australian poet, was born in China in 1955 and went to Australia in 1991 as a $\mathrm{PhD}$ student. He obtained a $\mathrm{PhD}$ in Australian Literature from La Trobe University and later grew into a prolific bilingual writer in English and Chinese. To date he has published more than eighty books of poetry, fiction, nonfiction and translation in both English and Chinese, and was once known as 'the angry Chinese poet' in Australia due to his harsh criticism of the mainstream Australian culture in his early works. He co-established the Chineselanguage literary magazine Otherland in Melbourne in 1995, with its Chinese name 原 乡 (motherland) opposite to the meaning of its English name. This wordplay implies 'otherland' is included in 'motherland'. ${ }^{257}$ Otherland, Australia's first Chineselanguage literary magazine, was mentioned in The Cambridge Companion to Australian literature as an example of 'the rise of ethnic minority writing. ${ }^{258}$ The magazine, though it started as a Chinese one, went bilingual in 2000 and then became an entirely English one in 2001.

Yi Sha was among the earliest contributors to Otherland. According to Yi Sha, he began to submit to Chinese magazines overseas in the early 1990s. After the Tiananmen Massacre on 4 June 1989, the political climate in mainland China was extremely tense. When Yi Sha found it impossible to publish his avant-garde poems at home, he started submitting them abroad. The New York-based literary magazine $A$ line, edited by Chinese poet and artist Yan Li, was the first to publish his poems. When Otherland was founded in 1995, Yi Sha also submitted poems, as is described by Ouyang Yu:

Many submissions then came from China. In my memory, the one who submitted

\footnotetext{
257 Ouyang Yu 欧阳昱. 'Gaobie hanyu: ershiyi shiji xin huaren de chulu?' 告别汉语: 二十一世纪新华人的出 路 ? (A farewell to Chinese: A way out for the new Chinese in the twenty-first century?), http://www.xys.org/xys/netters/psi4/ouyang.txt, accessed 16 October 2017.

${ }_{258}$ Elizabeth Webby. ed. The Cambridge Companion to Australian Literature. Cambridge: Cambridge University Press, 2006, p. 168.
} 
most frequently was a person named Yi Sha. He submitted both fiction and poetry. I liked his works very much and published them in almost every issue. At that time, his poetry, both unique and peculiar, was written in a style totally different from contemporary poetry in mainland China, also similar to my own style. That was why I selected and even translated his poems.

这时，来自中国的稿件颇多，记忆中，来得最多的是一个名叫伊沙的人，既 有小说, 也有诗歌, 我很喜欢, 几乎期期选发。他的诗歌当时独树一帜, 比 较另类, 凸显出一种与当代大陆诗歌迥异不同的诗风, 也颇与我的诗风切近。 这是我选发乃至选译的初衰。259

Apart from publishing Yi Sha's works in Otherland, Ouyang Yu started translating them into English. His translations of Yi Sha were widely published in Australian literary magazines and elsewhere, including HEAT, Ulittara, Island, LiNQ, Westerly, Overland, Blast and Agenda (UK). When explaining why HEAT, the most selective Australian magazine then, chose Yi Sha's poems, Ouyang Yu said:

Ivor Indyk, their editor-in-chief, was originally co-editor of Southerly, a magazine based at the English Department, University of Sydney. Due to the discord among the editors, he left his position in a fit of pique and raised a flag himself, establishing HEAT magazine, which later became one of the most prestigious magazines in Australia. At the initial stage, he had some sort of anger in him. I had then been in Australia for only a short period. Due to my own experiences of being discriminated in this white country, I also had anger in my poetry, thus I got the nickname 'the angry Chinese poet'. Yi Sha's poetry was then highly marginalised in China and thus had some sort of anger. It was such anger and vigour that added fresh strength to the Australian poetry scene.

\footnotetext{
259 Ouyang Yu 欧阳昱. 'Dapo xintian: dangdai zhongguo shige de yingyi' 打破新天: 当代中国诗歌的英译 (Breaking new sky: English translation of contemporary Chinese poetry). Literature in Chinese 华文文学, No. 3, 2013, p. 25.
} 
该杂志主编艾佛 - 印迪克（Ivor Indyk）本是悉尼大学英文系文学杂志《南 风》(Southerly) 副主编, 因与主编向有龃齝, 一气之下卸掉该职, 自己拉起 一杆旗, 创办了《沕》杂志, 后来成为澳大利亚名声最响的招牌杂志之一。 杂志初创期间, 他是带着一股气的。我刚到澳洲不久, 由于在这个白人国家 亲身经历了很多歧视现象, 诗歌中也是带着一股气的, 故有人称我为 “ the angry Chinese poet”（愤怒的中国诗人）。伊沙的诗歌，在当时的中国很受排 挤, 也是带着一股气的。正是这种气和气势, 给澳洲诗坛注入了一种新鲜的 力量。 260

Ouyang Yu attributes the popularity of Yi Sha's poetry among the literary magazines, especially in HEAT's case, to the sympathy among the author, the translator and the editor, as they shared a feeling of being 'discriminated and marginalised', the 'some sort of anger'. This anger generated 'vigour', which became a productive and seminal force in art. Coincidentally, the situation is similar to the state of the Minjian Poets at the Panfeng Conference. They also had some sort of anger within them, as they felt they were deliberately marginalised and neglected by the mainstream. In other words, they were 'un-officialised'. Their reaction to this was to embrace their state of being 'unofficial', to produce more 'unofficial' literature in both aesthetical and institutional senses and to strive to make it influential, as a counterattack to the official and mainstream.

The sympathy and affinity between Yi Sha and Ouyang Yu at that time suggests that the concept of minjian was not an isolated phenomenon in China, and that it was a sentiment that resonated with Chinese poets living outside China. Such poets as Ouyang Yu also identify with minjian. In a speech delivered in 2002, Ouyang Yu talked about the overseas minjian: 
I personally think the real 'minjian' exists overseas, among 'emerging writers' and 'developing writers' who write persistently, as well as some 'established writers' whose works have been banned in mainland China. These 'overseas minjian' writers are unlike the 'established writers' (except those who are banned in mainland China) whose works are popular in the both worlds: they have readers in the mainland, Hong Kong and Taiwan while they have translators in the west. These writers are unpopular in the both worlds: they find no place not only in the mainstream society but in their 'original mainstream society'.

我个人认为，真正的 “民间” 在海外、在海外坚持写作的 “崛起中作家” 和 “发展中作家”、以及一部分作品被大陆封杀的 “地位确立作家”之中。这 些 “海外民间” 作家不像 “地位确立作家” (被大陆禁止的除外)，东西两边 讨好, 大陆港台有人读, 西方有人翻译, 他们的东西则基本上两面不讨好, 不仅在主流社会，就是在“原主流社会”也是没有地位的。261

'Emerging writers', 'developing writers' and 'established writers' are the labels used to classify writers when they apply for writing funds in Australia. For 'established writers' it is easy to get funding, while for the former two types it is difficult. Unlike Obscure Poets, Bei Dao 北岛, Gu Cheng 顾城, and Yang Lian 杨炼, who had become 'established' when they went abroad and thus could rely on western translators, Ouyang Yu only published one poem in China before he went to Australia in 1991. He had no other choice but to write in English. The characteristics of minjian were presented in him in double senses: his Chinese poems were a bit too avant-garde to be accepted by the mainstream poetry circles in China, while his English poems were also marginalised in Australia. He was 'unofficial' on two levels and thus could easily identify with the Chinese minjian poets.

\footnotetext{
${ }^{261}$ Ouyang Yu 欧阳昱. 'Gaobie hanyu: ershiyi shiji xin huaren de chulu?' 告别汉语: 二十一世纪新华人的出 路? (A farewell to Chinese: A way out for the new Chinese in the twenty-first century?), http://www.xys.org/xys/netters/psi4/ouyang.txt, accessed 16 October 2017.
} 
After the founding of Otherland magazine, Ouyang Yu later founded Otherland publishing, an independent press. His attitude towards book publishing is also somewhat 'unofficial'- he has self-published most of his own poetry collections in Chinese, though his English poetry books are generally published by other presses. This is a sound strategy, as Chinese poetry generally has no market in Australia and selfpublication is a method to make his work survive. However, he also publishes his own English books through Otherland, when they are rejected by other presses. His selfpublished books are sometimes quite influential and have even led to international literary events. One notable example was the publication of In Your Face: Contemporary Chinese Poetry in English Translation (2002), which introduced such new minjian poets as the Lower Body Group to English readers for the first time. The book, after being rejected by many publishers, was eventually self-published by Ouyang Yu. Sidse Laugesen, a Danish poet, was very interested in the book and organised a Chinese poetry festival in Denmark in April 2004, inviting ten Chinese poets from In Your Face, including Lower Body Poets like Shen Haobo and Yin Lichuan. $^{262}$

Apart from publishing his own work, Ouyang has also helped many other writers, especially Chinese writers in Australia, publish their books, including John Sheng's 盛 约翰 Love in the City 城市之恋 and Linzi’s 林子 Chu Songs 楚歌. Ouyang Yu explained in an interview in 2012, 'I did not charge them even a penny and am planning to publish more books, because I want to offer the greatest convenience through this press for the overseas Chinese writers who have difficulty publishing their books. ${ }^{263}$ This idea also led to Otherland's publication of many mainland Chinese poets, including

\footnotetext{
${ }^{262}$ Ouyang Yu 欧阳昱. 'Dapo xintian: dangdai zhongguo shige de yingyi' 打破新天：当代中国诗歌的英译 (Breaking new sky: English translation of contemporary Chinese poetry). Huawen wenxue 华文文学 (Literature in Chinese), No. 3, 2013, p. 31. The Chinese poets invited to the festival included Bei Dao 北岛, Yang Lian 杨炼, Jing Bute 京不特, Ouyang Yu 欧阳昱, Yu Jian 于坚, Shen Haobo 沈浩波, Sheng Xing 盛兴, Yin Lichuan 尹 丽川, Zhai Yongming 翟永明 and Xi Chuan 西川. It was the first time the Lower Body Poets were invited to attend literary events in the west.

${ }^{263}$ Liang Yujing 梁余晶 and Ouyang Yu 欧阳昱. “Guanyu fanxueyuan, “fennu” yu shuangyu一Ouyang Yu fangtan’ 关于反学院、“愤怒”与双语——欧阳昱访谈 (Regarding anti-academy, 'anger' and bilingualism: an interview with Ouyang Yu). Huawen wenxue 华文文学 (Literature in Chinese), No.2, 2012, p. 33.
} 
Yi Sha.

It is not mainstream practice to publish a book in a foreign country whose primary language is different from the author's. Such cases are mostly for political reasons, such as Aleksandr Solzhenitsyn's The Gulag Archipelago, whose first Russian edition was published by Éditions du Seuil in France in 1973. However, for Chinese poets like Yi Sha, the major reason to publish a book in such a way is more economic than political. Along with China's growth of commercialization in publishing in the 1990s, the publication of poetry books, due to its unprofitable nature, was unprecedentedly marginalized. A large majority of poets had to publish their poetry collections at their own expense. For example, the publication of Yi Sha's first collection, Starve the Poets, cost him four thousand yuan, which was not a small sum of money for an individual in 1994. It took Yi Sha a couple of years to pay off the debt. ${ }^{264}$ What is termed 'vanity publishing' in the west was indeed common practice for Chinese poets since the 1990s, or they would remain unpublished and silenced. For them, self-publishing was not for vanity, but for the survival of their work.

The other instrumental figure in the publication of Yi Sha's Tang is the poet and editor Zhong Dao, who founded Shi Cankao 诗参考 (Poetry reference), a notable unofficial magazine, in November 1990. It started as a biannual publication in the form of a newspaper in Heilongjiang until 1995, when it moved to Beijing and became an annual magazine, which continued to be published until 2017. ${ }^{265}$ In April 1993, it published a feature on Yi Sha in the No. 6 and 7 issue, which was its 'most influential issue'. ${ }^{266}$ In 2000, it gave its 'Poetry reference Ten Years' Award' 《诗参考》十年成就奖 to Yi Sha. In 2005, Zhong Dao edited ten poetry books to be published in a series entitled

264 Yi Sha, 'Interview with Liang Yujing', 2016, see Appendix

265 'Yong 28 nian shengming pinzhi dazao de shige diguo Shi cankao' 用 28 年生命品质打造的诗歌帝国《诗参 考 》 (Poetry reference: A poetry empire constructed with 28 years of life), http://blog.sina.com.cn/s/blog_7f083ea80102x5h5. html, accessed 1 November 2017. 266 Ibid. 
'Shi cankao shiwu nian jinku' 《诗参考》十五年金库 (Poetry reference fifteen years' treasury), and Yi Sha's Tang was one of them. ${ }^{267}$ However, Zhong Dao 'encountered a number of setbacks but still failed to get an ISBN in China', and he was 'nearly swindled out of his money when attempting to buy an ISBN.' 268

In her monograph Censored: Distraction and Diversion Inside China's Great Firewall, Margaret E. Roberts identifies three mechanisms of censorship in contemporary Chinese publishing: fear, friction and flooding. The method of fear affects the flow of information by deterring the media or individuals from distributing, analysing, collecting, or consuming certain types of information; friction, the second type, acts like a tax on information by directly increasing the costs of distribution of and access to information, diverting the media and individuals away from censored information; flooding, the last type, vastly decreases the costs of particular information in order to increase the relative costs of competing information, influencing the media by presenting them with cheap, pre-packaged, easy-to-publish information. ${ }^{269}$ In the mechanism of friction, the government throttles the flow of information, making it difficult to access, rather than banning it outright by law. People can still access the information but have to spend more time, energy or money to collect the data.

Though Roberts's study of friction mainly focuses on Internet censorship, this mechanism also functions in traditional media such as book publishing. The high cost of officially publishing a book is a case in point. When most people cannot afford the cost of self-funded publication of a book, the economic restriction begins to function as a form of friction. According to Zhong Dao, 'an ISBN costs 10,000 to 15,000 yuan and a book series number 丛书号 costs 30,000 yuan at least. ${ }^{270}$ Considering that

\footnotetext{
267 Other poets in the same series included Yan Li 严力, Xu Jiang 徐江, Yang Xie 杨邪, Zhang Ping 章平, Nan Ren 南人, Ouyang Yu 欧阳昱, Shuimu Qinghua 水木清华, Li Wei 李伟 and Hu Jiujiu 胡赴赳.

268 Zhong Dao 中岛. 'General preface' 总序. In Yi Sha 伊沙. Tang 唐 (Tang). Melbourne: Otherland Publishing, 2004.

269 Margaret E. Roberts. Censored: Distraction and Diversion Inside China's Great Firewall. Princeton: Princeton University Press, 2018, pp. 42-43.

270 Zhong Dao 中岛. 'General preface’ 总序. In Yi Sha 伊沙. Tang 唐 (Tang). Melbourne: Otherland Publishing,
} 
Zhong Dao made these remarks in 2004, the price of an ISBN was quite expensive. On a certain level, the high cost of publishing a book is a form of censorship, of limiting freedom of the press, not through political but economic means.

Considering the severe environment of publication in mainland China, it is not difficult to understand why Poetry reference collaborated with Otherland Publishing to bring out this book series. After a series of unsuccessful attempts to obtain an ISBN for the book series in China, Zhong Dao turned to Ouyang Yu, who helped by giving him an Australian ISBN for free. Although bearing an Australian ISBN, the other aspects of publication, including design, formatting, printing and circulation, were all done in China. In a sense, Tang is an Australian book written, made and sold completely in China. Zhong Dao's words in the preface are with a hint of bitter humour: 'I am very grateful to the great support from "the Australian Publisher".' The quotation marks imply that it is not a genuine Australian book but a Chinese book that acquires its official identity through the Australian ISBN in an unofficial way. Strictly speaking, this operation is illegal in China, as all foreign books printed in China should be shipped out of China first and then imported through the customs. However, in reality, there is usually no punishment, for poetry books, generally unprofitable, only circulate among poets, rather than being sold in bookstores to the public.

The publication of Tang, a case of Chinese minjian made in Australia, is a vivid illustration of the global dimensions of the production and transmission of contemporary Chinese poetry. It is an example of Chinese poets going overseas in order to break through the economic control of the government and to make the publication of their work possible in a society with limited freedom of the press. The publication also adds a global dimension to the very practice of minjian itself. By tapping into international resources and joining forces with their overseas counterparts, the Chinese poets uncover the possibility of a transnational fraternity based on their shared vision 
of minjian that transcends geopolitical boundaries.

\section{Yi Sha in Translation: Minjian Brotherhood through 'Gift-exchange'}

As discussed in the previous section, Ouyang Yu has played an instrumental role in the introduction of Yi Sha's poetry to an overseas audience, and his tireless efforts to promote Yi Sha's work are based on their aesthetic affinity as well as a mutual sympathy towards each other's marginal status in their respective cultural environment. Ouyang Yu found Yi Sha's poetry 'unique and alternative, written in a style different from the contemporary mainland poetry', and also similar to his own poetry. ${ }^{271}$ Thus Ouyang Yu's decision to translate Yi Sha's poems into English seems to have a strong emotional element, inspired by a sort of transnational minjian brotherhood. Though Ouyang $\mathrm{Yu}$ has a superior command of English, he is not a native speaker and his translations, which include a number of his own creative coinages of expressions, are anything but products in the traditional sense of 'perfection'. However, they received warm acceptance from magazine editors and were widely published. From 1997 to 2000, a large number of Yi Sha's poems appeared in mainstream publications in the Englishspeaking world, including the Australian magazines, HEAT, Ulittara, Island, LiNQ and Westerly and in the British magazine Agenda. ${ }^{272}$ According to Ouyang Yu, Yi Sha's poetry has a 'vigour that breathes new life into the Australian poetry scene', ${ }^{273}$ though at times it has also received negative feedback. For instance, Gig Ryan, the poetry editor of The Age, once refused to publish Yi Sha's poetry because she found his work imbued with a sense of male chauvinism. ${ }^{274}$

\footnotetext{
271 Ouyang Yu 欧阳昱. 'Dapo xintian: dangdai Zhongguo shige de yingyi' 打破新天: 当代中国诗歌的英译 (Breaking new sky: English translation of contemporary Chinese poetry). Huawen wenxue 华文文学 (Literature in Chinese), No. 3, 2013, p. 25.

272 Ibid, p. 25.

273 Ibid, p. 25.

274 See Note 31, Ouyang Yu 欧阳昱. ‘Dapo xintian: dangdai Zhongguo shige de yingyi’ 打破新天：当代中国诗 歌的英译 (Breaking new sky: English translation of contemporary Chinese poetry). Huawen wenxue 华文文学 (Literature in Chinese), No. 3, 2013, p. 35.
} 
Ouyang Yu, however, was not Yi Sha's first English translator. Earlier efforts at translating Yi Sha's poetry into English were made by the American poet and translator, Denis Mair. Mair, born in 1951, holds an MA in Chinese from Ohio State University and is a prolific translator from Chinese into English. According to Yi Sha, Mair was introduced to his poetry through the New York-based Chinese poetry magazine, A Line, edited by Yan Li. According to Yi Sha's account, in 1994, Mair was working as a translator in a monastery in Taiwan. He stayed there for three months and felt quite bored until he received Yi Sha's poetry collection from Yan Li. Mair read the book all night and suddenly felt how beautiful the mortal world was. Then he went downhill the next morning. After he left the monastery, he began to translate Yi Sha's poetry into English. ${ }^{275}$ Yi Sha has said that Mair's translations are quite good, as they have received positive feedback at many international poetry events. ${ }^{276}$ However, Mair did not publish many of his translations, partly because he was then not quite familiar with the world of publication.

Ouyang Yu and Dennis Mair's efforts as translators converged in 2002, when Yi Sha self-published a bilingual collection, Selected Poems of Yi Sha 伊沙短诗选, in Hong Kong, which consists of 22 poems, a combination of the translations by Mair and Ouyang. As the book is self-published and has no distribution overseas, its influence is quite limited, but it is the first step that Yi Sha consciously took to seek recognition abroad, particularly in the English-speaking world. Then, in 2012, Vagabond Press published Poems of Yi Sha, Shu Cai \& Yang Xie, translated by Ouyang Yu, as their Asia Pacific Poetry Series 3, with an introduction by the translator. Although the book only included 26 poems by Yi Sha, Ouyang Yu was full of praise for the poet: 'It is not hard to understand why Yi Sha's poetry was such a hit in Australia for his is a poetry that is accessible, direct, hard-hitting, filled with riveting stories that tell of all facets of

275 Yi Sha, 'Interview with Liang Yujing', 2016, see Appendix.

276 Ibid. 
contemporary Chinese life, often with an eye on the sordid part of it'. ${ }^{277}$.

The most influential translations of Yi Sha in English were done by Simon Patton and Tao Naikan, two Australian translators, and their work was published by Bloodaxe Books, the UK's leading poetry publisher, in 2009, titled Starve the Poets!. The book consists of 142 pages of Yi Sha's poetry, selected from over 340 poems sent to the translators by Yi Sha, written between 1988 and 2007. Included is a long, scholarly introduction by the translators, in which they discuss some key features of Yi Sha's poetry, such as Yi Sha's stance of ordinary people rather than that of the elevated intellectual, Yi Sha's insistence on illegitimacy and Yi Sha's concise and direct style. ${ }^{278}$ According to Yi Sha, he met with Simon Patton in Xining, when Patton was visiting China and travelling with Yu Jian. Patton, then an editor of Chinese poetry for the Poetry International website, asked Yi Sha to send him a batch of poems. ${ }^{279} \mathrm{He}$ translated several of them and put them on the website, which led to Yi Sha being invited to the 38th Poetry International Festival Rotterdam in 2007 and the Seventh Aldeburgh Literary Festival in 2008. The Bloodaxe collection of Yi Sha's selected poems also appeared in 2009 and made Yi Sha the first among the Panfeng Polemic poets to have a poetry collection in English translation published overseas, earlier than Xi Chuan, Ouyang Jianghe, Yu Jian, Han Dong, Wang Jiaxin and Zang Di.

Apart from English translations, Yi Sha also has a volume of poetry, A project of flesh and soul, translated into Hebrew, and published in Israel in 2006. ${ }^{280}$ According to Yi Sha, the Israeli translator had been looking for him for two or three years before they finally got in touch. At that point, the translator had already finished the manuscript. Shortly after Yi Sha signed the agreement, the book was released in Israel. ${ }^{281}$ In 2016,

\footnotetext{
277 Ouyang Yu, 'Introduction'. Yi Sha, Shu Cai and Yang Xie. Poems of Yi Sha, Shu Cai \& Yang Xie, trans. Ouyang Yu. Newtown NSW: Vagabond Press, 2012, p. 11.

278 Tao Naikan \& Simon Patton, 'Introduction: "There Is Style in the Blood"” Yi Sha. Starve the Poets!, trans. Simon Patton and Tao Naikan. Northumberland: Bloodaxe Books, 2008, pp. 11-13.

279 Yi Sha, 'Interview with Liang Yujing', 2016, see Appendix.

280 The Hebrew title in Chinese translation is Ling yu rou de xiangmu 灵与肉的项目. I translated the title from the Chinese.

281 Yi Sha, 'Interview with Liang Yujing', 2016, see Appendix.
} 
two volumes of Yi Sha's poetry in German translation, Überquerung des gelben Flusses $1 \& 2$ (Crossing the Yellow River $1 \& 2$ ), translated by Martin Winter, were released in Austria. From 2016 to 2017, four volumes of Yi Sha in Korean translation, translated by Chinese-American Hong Junzhi 洪君植, were published, two in South Korea and two in America.

In her study of the translation of Chinese literature in the 1980s, Bonnie S. McDougall states that there co-existed two translation zones: Authoritarian Command versus Gift Exchange. The authoritarian model is the state-sponsored translation linked with the concept of authorization, such as the translation practice at the Foreign Literature Press. The reciprocal, or gift-exchange, model is the informal translation that happened through the personal contact between the translatee and the translator, with the example of McDougall's translation of early Obscure Poets such as Bei Dao. McDougall argues that 'gift-exchange relationships are most likely to be practiced and most likely to be regarded as successful in the case of literary translation, where creativity is central to the process and the reception of the translation'. ${ }^{282}$ Although her study, based on her own experiences as a translator in these two zones, focuses on the Chinese-English translation practice in Beijing in the 1980s, the two models still existed in the first decade of the twenty-first century and continue to take place in the Chinese-English translation practice nowadays. As McDougall states, 'it is unlikely that those circumstances [in the 1980s] could ever be repeated in exactly the same form. However, it is entirely possible that similar situations could arise in other places and times.' 283 This prediction is fundamentally true, as the English translations of Yi Sha in the 1990s and 2010s took place exclusively in the gift-exchange mode.

Unlike authoritarian command, the gift-exchange mode provides an unofficial way of translating Chinese poetry without any government intervention, which aligns well with

\footnotetext{
282 Bonnie S. McDougall, Translation Zone in Modern China: Authoritarian Command Versus Gift Exchange. Amherst, MA: Cambria Press, 2011, p. 139.

${ }^{283}$ Ibid, pp. 139-40.
} 
the ethos of minjian poetry. Compared to the translation of Obscure Poets such as Bei Dao, the translation of Yi Sha's poetry has carried the unofficial characteristics of giftexchange further. What is notably different between the gift-exchange mode in Yi Sha's time and that of the $1980 \mathrm{~s}$ is the expansion and diversification of contact zones. According to McDougall, the contact zones in the 1980s were centred in the big cities such as Beijing, which provided venues for the translatees and the translators to meet and exchange their 'gifts'. This mode of gift-exchange still exists in more recent decades but is no longer the dominant one, as the contact zones have been extended to correspondence and the Internet. Denis Mair discovered Yi Sha via overseas publications, Ouyang Yu discovered him via submission correspondence, and Simon Patton discovered him via meeting in person and emails. The contact zone is no longer confined to a venue but becomes varied, including both real and virtual contacts. These new venues of contact have enabled Yi Sha, a minjian poet operating away from the cultural and political centre of Beijing, to fully participate in the gift-exchange mode of translation from the 1990 s to the 2010 s.

Apart from the expansion and diversification of contact zones, which had a decentring impact on translation activities, the translation of Yi Sha's poetry into English also provides a contrasting perspective on the identities of the translators. McDougall finds that, in the 1980s, many of the translators were female English speakers coming from abroad, mostly budding Sinologists, students or junior researchers. ${ }^{284}$ In making this observation, McDougall seems to suggest that translation of modern Chinese poetry remained a gender-specific cottage industry that mainly attracted the female scholar. As the contact zone has expanded, the translators have also become more diversified. All three English translators of Yi Sha are male and, according to Yi Sha's own accounts, the translation activities were all inspired by a sense of mutual affinity, sympathy and brotherhood. The identities of the translators also cover a broader range from poet, professional translator to academic scholar. In Ouyang Yu's case, he is Australia-based

\footnotetext{
284 Bonnie S. McDougall, Translation Zone in Modern China: Authoritarian Command Versus Gift Exchange. Amherst: Cambria Press, 2011, p. 93.
} 
but not a native speaker of English. Rather, he is a bilingual writer who is able to infiltrate English-language publishing by using English creatively in his own peculiar way. Ouyang Yu's translation and publishing activities have exposed the power dynamics of translation as 'gift-exchange' and challenged the unwritten rules about who has the right or authority to translate. His ongoing efforts to translate and promote Yi Sha's poetry in English have forged a transnational minjian brotherhood that offers resistance against the cultural authorities and gatekeepers both in China and in the West.

\section{Embracing Translatability: Minjian and World Poetry}

In 1990, The New Republic published a book review by sinologist Stephen Owen, entitled 'The Anxiety of Global Influence: What Is World Poetry?', reviewing Bei Dao's The August Sleepwalker (1990), translated by Bonnie S. McDougall and published by New Directions. ${ }^{285}$ Referencing Harold Bloom's famous term, 'the anxiety of influence', Owen's book review made a series of comments, both inspiring and controversial, on Bei Dao's poetry and modern Chinese poetry in general. Bei Dao, the representative of Obscure Poets, but by then a Chinese poet newly translated into English, was in Owen's eyes writing a 'new poetry' free of history and Chinese poetic tradition:

These 'new poetries' - new Chinese poetry, new Hindi poetry, new Japanese poetry-have often been formed by reading Western poetry in translations, sometimes in very poor translations. Which is to say that we, the Anglo-American or European part of the international audience, are reading translations of a poetry that originally grew out of reading translations of our own poetic heritage. If poetry is, as the cliché goes, what gets lost in translation, this is a most troubling

\footnotetext{
285 Bonnie S. McDougall's translation of The August Sleepwalker was first published in the UK by Anvil Press Poetry in 1988 and then republished in the US by New Directions in 1990. The book Stephen Owen reviewed was the New Directions edition.
} 
situation. ${ }^{286}$

Owen went on to suggest that Bei Dao was creating a 'world poetry' which contains some local colour but the images were highly translatable. In his opinion, the success of Bei Dao's poetry in English was not entirely the achievement of the translator's skills but largely because Bei Dao had written an 'international poetry' that translated itself. Owen's negative attitude towards such poetry was apparent:

If this had been an American poet writing in English, would this book have been published, and by a prestigious press? We must wonder if such collections of poetry in translation become publishable only because the publisher and the readership have been assured that the poetry was lost in translation. But what if the poetry wasn't lost in translation? What if this is it?

This is it. ${ }^{287}$

Owen's remarks soon received a number of responses from other critics, mostly refutations, among which the most notable voices came from Michelle Yeh and Rey Chow. Both Yeh and Chow seized upon the word 'anxiety' and offered alternative spins on it. In a Chinese article entitled 'Chayi de youlü' 差异的忧虑 (The anxiety of difference), published in Today in 1991, Yeh uses the word 'anxiety' to describe Owen's own unease with modern Chinese poetry, pointing out the paradox in Owen's attitude that, while stressing the specificity of Chinese poetry in the context of international poetry, he denied the possibility of difference within Chinese poetry, such as the difference between traditional and modern Chinese poetry. ${ }^{288}$ The word 'anxiety'

\footnotetext{
286 Stephen Owen. 'The Anxiety of Global Influence: What Is World Poetry?' The New Republic, 19 November 1990, p. 29.

287 Ibid, p. 31.

288 Michelle Yeh 奚密, ‘Chayi de youlü—dui Yuwensuo'an de yige huixiang’ 差异的忧虑——对宇文所安的一 个回响 (The anxiety of difference: a rejoinder to Stephen Owen). Zhong wai wenhua yu wenlun 中外文化与文论 (Chinese-Foreign Cultures \& Literary Theories), No. 2, 1997, p. 63. This article was originally published in Jintian 今天 (Today), No. 1, 1991, pp.94-96.
} 
reappeared in Rey Chow's criticism of Owen in her introduction to Writing Diaspora: Tactics of Intervention in Contemporary Cultural Studies (1993). Like Yeh but more harshly, Chow described Owen's disdain towards the new 'world poetry' as 'a sense of loss' and 'an anxiety over his own intellectual position'. ${ }^{289}$ She further used Freud's study of melancholia to describe Owen's attitude as the 'Orientalist melancholia', asserting that it is 'the anxiety that the Chinese past which he has undertaken to penetrate is evaporating and that the sinologist himself is the abandoned subject. ${ }^{290}$

In fairness, Owen's book review reveals some truths that underlie modern Chinese poetry: that it is a poetry greatly influenced by translations, by reading or misreading foreign poetry, primarily European and American poetry, thus inevitably having certain elements similar to Western poetry. It is, however, a prejudice to understand Chinese poetry influenced by translation as a derivative phenomenon and a degradation of quality, merely due to a perceived loss of 'Chineseness'.

Owen, though much criticised, was not the only one who held such a view. Another 'anxiety' appeared in 1993, when Bonnie S. McDougall, the translator of Bei Dao in Owen's review, published an article 'The Anxiety of Out-fluence: Creativity, History and Postmodernity', whose topic, unrelated to Owen's book review, was modern Chinese literature in general, instead of only Bei Dao's work. Beginning with the story of Mary Shelley 'who created Frankenstein who created the Monster', her article explored the tradition of 'plagiarism' and 'creativity' in Chinese literature in the 1980s. A similar voice came from her words as she wrote: 'the spectacle of Chinese writers in the last years of this century attempting to engage in postmodernism may be seen primarily as simply a depressing recycling of recycled novelties in trivialised and debased forms. ${ }^{291}$ McDougall's article, though not as strident as Owen's book review,

\footnotetext{
289 Rey Chow. Writing Diaspora: Tactics of Intervention in Contemporary Cultural Studies. Bloomington: Indiana University Press, 1993, p. 3.

290 Ibid, p. 4.

291 Bonnie S. McDougall, 'The Anxiety of Out-fluence: Creativity, History and Postmodernity'. In Wendy Larson
} 
expressed her concern about the pursuit of Western literary trends like postmodernism among Chinese writers. Considering that she was the translator of Bei Dao in the article written by Owen, her attitude towards contemporary Chinese literature seemed somewhat paradoxical, not unlike the paradox Michelle Yeh found in Owen's comments. But, unlike Owen's criticism of modern Chinese poetry, what McDougall disapproved of was the imitation of Western literary trends among Chinese writers in the 1980s, except in Obscure Poetry, and hence she excluded Bei Dao from the target of her criticism. Rather, she listed Obscure Poetry as one of the only two examples that had left an impression on Western readers and critics in the 1980 s. $^{292}$ This could probably explain why she translated Bei Dao while criticising other literary trends on the Chinese literary scene.

The word 'anxiety' in the debate over the position of contemporary Chinese literature in the world has been a dual one. While the critics employed this word to describe Chinese writers, they, too, revealed their own anxiety, as Yeh's and Chow's criticism of Owen asserted. Anxiety, as a feeling, often grows out of uncertainty and a lack of information to judge the panoramic landscape. It usually fades away as the years pass by, when more and more evidence gradually rises to the surface. Needless to say, we should bear in mind that Owen's and McDougall's comments were made respectively in 1990 and 1993. Nearly thirty years have passed and now we have the opportunity of reconsidering their views and comparing them with what we have witnessed in the actual development of Chinese poetry.

In the past thirty years, Chinese poets and writers have continued to 'imitate' foreign literature, through good or poor translations. Likewise, through translations perfect or imperfect, they have also exerted their own influence in the world. In poetry, older Obscure Poets Bei Dao and Yang Lian have become prominent figures in world poetry.

and Anne Wedell-Wedellsborg, eds., In Inside Out: Modernism and Postmodernism in Chinese Literary Culture. Aarhus: Aarhus University Press, 1993, p. 110.

292 Ibid, p. 109. The other example McDougall mentioned was the reportage, Chinese Lives. 
Younger poets like Yu Jian, Han Dong, Yi Sha, Xi Chuan, Zang Di and Ouyang Jianghe all have had their voices heard on the world stage through English translations. In the case of Yi Sha, we have witnessed a more proactive and self-directed approach to engaging with Western poetry through a broad array of translational activities. In the relationship between Yi Sha and his translators, we also begin to see a new giftexchange mode based on a burgeoning minjian brotherhood that is both translingual and transnational. Perhaps we could say with a measure of confidence that contemporary Chinese poetry in general and minjian poetry in particular have overcome the 'anxiety of influence' and have come to terms with the issue of translatability.

More recent scholarship in world literature has taken note of and responded to the changing position of contemporary Chinese poetry in the world. Jacob Edmond's study in 2012 places Yang Lian and Bei Dao's poetry on the same axis with the poetry of Arkadii Dragomoshchenko, Lyn Hejinian, Dmitri Prigov and Charles Bernstein, based on their 'common concern with strangeness in textual practice, cross-cultural encounter, and transnational affiliation'. ${ }^{293}$ Eschewing the dichotomies of East/West and local/global, Edmond focuses on how this diverse group of poets responds to world historical changes and how their poetics of strangeness 'have shaped conceptions of the global'. ${ }^{294}$ In Edmond's assessment, Bei Dao's poetic position is neither national nor global but in-between, revealing 'how national and world literature are mutually constituted and contested by acts of translation'. 295

In his influential reconceptualization of world literature in 2003, David Damrosch gives a more cosmopolitan definition of the term than Owen's 'world poetry': 'World literature is not an infinite, ungraspable canon of works but rather a mode of circulation and of reading, a mode that is as applicable to individual works as to bodies of material,

\footnotetext{
293 Jacob Edmond. A Common Strangeness: Contemporary Poetry, Cross-Cultural Encounter, Comparative Literature. New York: Fordham University Press, 2012, p. 3.

294 Ibid, p. 3.

295 Ibid, p. 124.
} 
available for reading established classics and new discoveries alike'. ${ }^{296}$ In Damrosch's theory of world literature, the two keywords are 'circulation' and 'translation', which serve as the determining factors in shaping world literature. It is telling that Damrosch also uses Bei Dao as an example of how works of world literature take on a new life through translations in new cultural contexts, eventually leading to one of his conclusions that: World literature is writing that gains in translation. ${ }^{297}$ As Damrosch suggests, 'literature stays within its national or regional tradition when it usually loses in translation, whereas works become world literature when they gain on balance in translation, stylistic losses offset by an expansion in depth as they increase their range. ${ }^{298}$

Although Edmond's and Damrosch's studies have not touched upon the latest developments in contemporary Chinese poetry, their fresh thinking on the practice of translation and the issue of translatability is amply echoed in Chinese minjian poetry. Though the word minjian has the implication of nativism, the Minjian Poets, in their attempt to build the broadest worldwide alliance in support of their colloquial poetics and unofficial stance, have always recognised the importance of translation. Many of them, like Yi Sha, have indeed embraced translation, not only because they themselves have been influenced by translations of foreign poetry, but because translatability, in their eyes, is a confirmation of good poetry.

Shen Haobo once remarked that 'To me, poetry is what is left in translation... on the premise that it's a good translation with a good translator's full endeavour' 我觉得, 翻译过后剩下的东西, 才是诗... 前提是, 这本身是个好翻译, 一个好译者全力 以赴的结果. ${ }^{299}$ Such a statement seems diametrically opposed to Robert Frost's famous saying 'poetry is what gets lost in translation'. To put it simply, Shen believes

\footnotetext{
296 David Damrosch. What Is World Literature? Princeton: Princeton University Press, 2003, p. 5.

297 Ibid, p. 281.

298 Ibid, p. 289.

299 Personal conversation with Shen Haobo on 7 September 2018.
} 
that poetry is what is translatable, whereas Frost's words imply that poetry is what is untranslatable. But in essence, Shen and Frost are talking about two poetries, and the divergence in their attitudes is linked to a fundamental question: What is poetry? For those who believes 'poetry is what gets lost in translation', poetry is primarily the linguistic beauty embedded in the original language. For a Minjian Poet like Shen Haobo who claims 'poetry is what is left in translation', poetry is, however, the idea, the structure and the facts that make a poem poetic.

A view similar to Shen's has also been expressed by Yi Sha, who, in his presentation at an international conference, 'Contemporary World Literature and China' 当代世界文 学与中国, in 2008, argued:

What are the elements 'easy to lose' or difficult to retrieve in translation? My answer is: musicality, tone, rhythm ... And what are the elements 'not easy to lose' or easy to retrieve? My answer is: words, structures, facts ... By contrast, it seems that the 'software' is easier to 'lose' while the 'hardware' is not easy to 'lose'. That is to say: those poets strong in their 'hardware' and 'yinggong' (hard skills), less liable to damage, benefit from translation, while those strong in their 'software' and 'qinggong' (light skills), more liable to damage, suffer losses.

在翻译中容易 “丢掉的东西” 或者说不易找回的东西是什么? 自找的答案 是：语感、口气、节奏……而不容易 “丢掉的东西” 或者说容易找回的东西 又是什么? 自找的答案是：词语、思路、事实……相较而言, 似乎 “软件” 更容易 “丢掉”，而 “硬件” 不容易 “丢掉”，也就是说：以“硬件” 见长喜 欢玩 “硬功” 的诗人受损率相对较低, 算是沾光了; 而以 “软件” 见长喜欢 玩 “轻功” 的诗人受损率相对较高, 算是吃亏了。300

\footnotetext{
300 Yi Sha 伊沙. ‘Zhongguo dangdai shige: cong “quanqiu hua” shuo kai qu’ 中国当代诗歌：从“全球化”说开去 (Contemporary Chinese poetry: starting from 'globalisation'). Jintian 今天 (Today) website, 16 January 2009. https://www.jintian.net/today/?action-viewnews-itemid-3051, accessed 20 June 2019. This article was originally a presentation given at the international conference 'Contemporary World Literature and China' 当代世界文学与中
} 
By using terms from computer science (hardware and software) and martial arts (yinggong and qinggong), Yi Sha contrasts what elements are lost and what elements are retained in poetry translation. He further uses the success of his poetry reading in Sweden in 2002 to illustrate how poetry still exists after being translated twice: the Swedish version of his poetry, which was translated from the English, still evoked great laughter among the audience. ${ }^{301}$ In sum, he attributes the success to the 'hardware' in his poetry, a quality he is proud of, and he claims: 'I will strengthen those elements hard to lose in translation - consolidate the construction of "hardware" and cultivate my “hard skills”, 我的写作就是要加强那在翻译中不容易 “丢掉” 的东西：加强 “硬 件”建设，修炼自己 “硬功” 302

Yi Sha's emphasis on the 'hardware'-words, structures, facts - coincides with the characteristics of his Colloquial Poetry, which attaches greater importance to the 'Poetry of Facts' than the rhetorical and stylistic features of poetry. That is the reason why Yi Sha's poetry does not lose much in translation. As his translators, Tao Naikan and Simon Patton, have noted, 'it is the idea of the poem that primarily drives it, rather than a distinctive linguistic manner [...] This directness [of Yi Sha's poetry] simplifies the translator's task in some ways'. ${ }^{303}$ Yi Sha's differentiation of 'hardware' and 'software' indicates that he himself is aware of this quality of his poetry, and he chooses to embrace the translatability of his poetry and turn it into an advantage. To Yi Sha, embracing translatability does not mean to write an easily translatable 'world poetry' as an end in itself. Rather, it is to honour the core features of Chinese minjian poetics and communicate them to the world through translation, and ultimately, make them the core features of world poetry.

\footnotetext{
国, hosted by Beijing Normal University and World Literature Today, the University of Oklahoma, in Beijing, from 16 to 18 October 2008 .

301 Ibid.

302 Ibid.

303 Tao Naikan and Simon Patton. 'Introduction: There Is Style in the Blood'. Yi Sha. Starve the Poets!, trans. Simon Patton and Tao Naikan. Northumberland: Bloodaxe Books, 2008, pp. 13-14.
} 


\section{Conclusion}

This research has aimed to trace the historical formation of minjian as a literary concept and the process in which it has been re-imagined in contemporary Chinese poetics. Based on a case study of Yi Sha, one of the most representative Minjian Poets who emerged after the Panfeng Polemic in 1999, I have identified colloquial poetics and unofficial stance as the two distinctive features of minjian poetry. Through close readings of Yi Sha's poetry and detailed analyses of his literary and social activities, I have demonstrated that minjian is best understood as a sustained poetic practice that operates alternately as a strategy and an ideal, enabling the poet to navigate the complex cultural spheres of a controlling state and the dominance of an authoritarian state ideology in the context of a competitive literary scene, and increasingly fluid configurations of world literature in the age of the Internet.

This thesis has demonstrated that the prominence of the Minjian Poets and their enaction of the minjian ideal at the turn of the millennium was not an accidental phenomenon but an outburst of the minjian elements that had been underlying contemporary Chinese poetry since the 1980s. On the one hand, Colloquial Poetry, a long existing but somewhat marginalised poetic trend, continuously developed, with its representative poets like Wang Xiaolong, Yu Jian, Han Dong, Yi Sha and Shen Haobo. By the end of the twentieth century, it had become an influential force on the Chinese poetry scene with an eagerness to be acknowledged. The Panfeng Polemic accidentally provided them with the title minjian, thus enabling a group of the Colloquial Poets to openly voice their opinion. However, the manner in which they debated their stance took the form of a chaotic polemic, instead of rational reasoning, although it was highly reasonable for them to argue forcefully their position for a poetics able to clearly demarcate themselves stylistically and ideologically from the existing literary establishment endorsed by the authorities. Through their efforts to construct and 
promote the minjian ideal, Colloquial Poetry, as a key element of the newly constructed minjian concept, and as a major poetic trend in contemporary China, has exerted great influence on the Chinese poetry scene of the twenty-first century.

At the same time, the minjian ideal is an overt expression of the position of 'being unofficial' that has served as the major source of poetic inspiration for contemporary Chinese poetry. In the history of the People's Republic of China, a large proportion of important poetry have been produced by poets who identify themselves with being unofficial rather than official. Examples range from the underground poetry during the Cultural Revolution and its representative Guo Lusheng, to the Obscure Poets and their unofficial publication Today, and to the various unofficial poetry groups and publications in the 1980s that constituted the major venue for the 'Third Generation' Poets. During the Panfeng Polemic, the appearance of the minjian concept reinforced the idea of 'being unofficial' and emphasized the importance of the unofficial as one of the major space for contemporary Chinese poetry. This notion was further spread and developed in recent decades with the rise of the Internet and proliferation of social media. Weibo and Wechat have provided major platforms for the new unofficial spaces for the publication and circulation of Chinese poetry. The unofficial is not 'anti-official' but a grey area, a third space, with more freedom, outside the official institutions. For Chinese poetry, such an area has always existed, though its form has varied from time to time, either in print or online, paper-based or digital.

The significance of the Panfeng Polemic of 1999 is that it placed in the foreground the term minjian as a manifestation of two important but neglected trends in contemporary Chinese poetry-Colloquial Poetry and the unofficial stance - and erected the word as a banner for many like-minded poets to follow. Though the Polemic was largely chaotic and irrational, it did lead to the popularity of the minjian concept on the Chinese poetry scene. For the Minjian Poets, the adoption of minjian as their name was both a strategy and the pursuit of an ideal. By adopting such a name, they gained an advantageous title to legitimise themselves; and they used it as a banner to attract fellow poets and seek 
support in their battle against the Intellectual Poets. Meanwhile, the two elements of the minjian concept were also what they pursued as goals of their aesthetic orientation. In this regard, they were both opportunists and idealists.

The renaissance of the minjian concept also brings back its originally multiple connotations in the Chinese context-'folk', 'earthly', 'simplistic', 'unofficial', 'nongovernmental' and 'native' — and gives it a new meaning in the context of contemporary poetry as the name of a poetry group. After the Panfeng Polemic, 'To be minjian' became the goal of not only the Minjian Poets but also of a variety of newly established, unofficial poetry groups. When the two long-existing elements in Chinese poetry were concomitantly represented by a single word minjian, it was instantly empowered. Minjian hence became an inclusive term that attracted a large number of poets, a position that numerous unofficial poetry groups identified with, and an ideal for people to pursue.

By analysing how Yi Sha builds his career as a representative minjian poet through his writing and literary activities, this thesis has shown how the poet manages to position himself at the forefront of the power dynamics and critical debates that have shaped contemporary Chinese poetry to date. Though Yi Sha was not the leading Minjian Poet during the Panfeng Polemic, the two main characteristics of minjian poetry are fully demonstrated by him throughout his entire career. As a practitioner of Colloquial Poetry and an unofficial poetry activist, Yi Sha is undoubtedly an exemplar of the minjian ideal.

Yi Sha's contribution to contemporary Chinese poetry lies in his steadfast belief in an earthly, colloquial and pared-down aesthetics, which was against the grain of the classical tradition as well as much of modern and contemporary Chinese poetry, and his persistent efforts to promote it in the Chinese avant-garde poetry circles. Under his influence, this aesthetics has become an important force to be reckoned with on Chinese poetry scene. For poetry in general, this earthly, colloquial and anti-lyrical poetics has appeared in many countries and languages, such as Charles Bukowski in English and 
Nicanor Parra in Spanish. Yi Sha has proved that it works fine in Chinese, a language rooted in a long classical tradition.

In poetics, Yi Sha has been persistent in his Colloquial Poetry since the publication of his debut collection, Starve the poets, in 1994. Yi Sha's poetry, often labelled as 'postmodernist writing', has three major characteristics: profanity, playfulness and political incorrectness. Yi Sha's poetry was not the first to possess such characteristics in China, but they have become the most prominent features in his creation and have made Yi Sha an outstanding poet with a unique style, in the 1990s. Yi Sha's most renowned short poems are all invariably representations of these characteristics. The aesthetic qualities (profanity, playfulness and political incorrectness) of Yi Sha's poetic ideal also reflect and reinforce his unofficial stance, because they can be considered a rebellion against the mainstream, culturally or institutionally. In this sense, the two aspects of the minjian concept work towards a common goal, namely to challenge the existing cultural and political authority.

Furthermore, Yi Sha's major contributions to Colloquial Poetry also include his aesthetic principles on the 'Post-Colloquial' and 'poetry of facts'. Though colloquialism is a distinct characteristic of Colloquial Poetry, Colloquial Poetry is not mere colloquialism in poetry but a system of 'earthly' aesthetics. Also, Yi Sha's poetic language is not colloquialism only but, in most cases, a refined colloquial idiom. For Yi Sha, what distinguishes 'Post-Colloquial' from 'Pre-Colloquial' poetry is 'poetry of facts', a concept coined by Yi Sha which serves as the key notion of his 'Post-Colloquial' poetics. Yi Sha believes poetry comes from the facts the poet narrates rather than the linguistic beauty the poet creates through his rhetorical skills. In other words, the poet's work is to present facts relevant to the poetic theme and it is definitely not to create a poetic atmosphere through figures of speech to demonstrate one's literary flare. This idea accentuates the material itself that a poet writes about as their primary thematic concern, and attaches no importance to the way a poet writes about it. This is the core of the earthly aesthetics promoted by Yi Sha and its fundamental aim is to disperse with 
excessive rhetoric. That said, however, it is important that Yi Sha's 'Post-Colloquial' poetics and 'poetry of facts' are taken as ideals and guiding principles rather than a golden rule for poetry writing or a complete poetic system. Even Yi Sha himself cannot always stick to his principles, for poets necessarily need all kinds of rhetorical devices to write poetry. Nevertheless, 'poetry of facts' provides a new path for Chinese poets, as Yi Sha has done and as he encourages others to get rid of redundant rhetoric and return to an earthly, more simple poetics.

In the digital age, Yi Sha gradually developed his identity as both a poet and a poetry activist who not only writes poetry himself but also takes part in and organises many activities. In these activities, through the use of social media, he has demonstrated the second element of the minjian concept-unofficial stance. In early 2000 s, he was actively engaged with an unofficial poetry website Poetry Jianghu, which became a gathering venue for the minjian poets. The unofficial nature of Poetry Jianghu is not only presented by its title jianghu, a grey area outside the official institution in martial arts fiction, but by the numerous polemics which have taken place on the forum of the websites. Each of these online polemics among minjian poets can be seen as a minor Panfeng Polemic, reflecting the duality of minjian both as a strategy and an ideal. On the one hand, these polemics were a kind of performance, in which the poets exhibited their personalities, temperaments and self-images. On the other hand, these polemics are also a demonstration of their poetics. Thus, Poetry Jianghu became a stage for the minjian poets in the first decade of the twenty-first century.

The most important poetry activities of Yi Sha are his establishment of Chang'an Poetry Festival and 'New Poetry Classics', respectively in 2010 and 2011. Both have an online presence. Chang'an Poetry Festival is an institutionalised social organisation of the minjian poets. It started in the form of private parties but later became an influential poetry organisation on the Chinese poetry scene, with its strict regulations, the open access to its online archives and its system of awards. Despite its claim to be 'unofficial', Chang' an Poetry Festival challenges the official/unofficial binary by linking itself with 
the classical poetic tradition of ancient Chang'an and by collaborating with a number of official and unofficial organisations, including many local universities, in holding poetry events. Chang'an Poetry Festival represents the complexity of the official/unofficial issue and shows its efforts to compete with the mainstream.

'New Poetry Classics' is a large, unofficial poetry project conducted by Yi Sha which includes three components: online recommendation (one poem a day), paper-based publication and awards. By the NPC, Yi Sha attempts to create the canon of twentyfirst century Chinese poetry. Though the NPC aims to include poetry of all styles, Yi Sha's own aesthetics still greatly affect his selection since he works as the sole editor and the gatekeeper of the project. Therefore, a majority of the selected poems in the NPC are Colloquial ones. Apart from the online recommendation, the NPC is published each year as a print anthology with the help of Shen Haobo, Yi Sha's publisher and fellow Minjian Poet. In contemporary China, the print publication of the NPC is in itself an attempt to canonise poems selected by the project. The project also includes a system of annual awards with distinct minjian characteristics. Akin to Chang'an Poetry Festival, the NPC demonstrates Yi Sha's ambition to canonise minjian poetry in order not only to challenge and compete with the mainstream but to assert his version of literary history of the twenty-first century with an emphasis on minjian's presence.

This thesis has delineated issues relating to a comprehensive understanding of minjian and a most important issue is the dynamics between 'nativism' and absorption of influences from other cultures, especially those from the Anglophone poets. The two most important figures who have influenced Yi Sha are Allen Ginsberg and Charles Bukowski, especially the latter. After Yi Sha got to know Bukowski's poetry in 1994, he began to translate it into Chinese and started his career as a poetry translator. Though Yi Sha's translations of Bukowski are imperfect, they have opened up new possibilities for Chinese poetry and extended the influence of minjian poetry. After many years of translating Bukowski, Yi Sha began to extend the minjian canon through his translation of poets like Rabindranath Tagore, with the purpose of establishing a refined 
colloquialism for poetry translation. These efforts again show that Yi Sha intends to provide for Chinese readers a new canon of world poetry with similar qualities to Chinese minjian poetics. Yi Sha's persistent efforts were effective to some extent, as his translations have made Bukowski a new literary icon among a considerable number of Chinese avant-garde poets.

While Yi Sha translated foreign poetry into Chinese, his own poetry was also transmitted overseas, either through Chinese publications or translations in other languages. His poetry book, Tang, for instance, was published in Australia, effectively breaking through the political and the economic control of print publications by the Chinese government. Meanwhile, Yi Sha's poetry was translated into foreign languages such as English, German, Hebrew and Korean. His major English translators include Denis Mair, Ouyang Yu, Simon Patton and Tao Naikan. These translation activities have mostly happened in a variant of what Bonnie McDougall has termed 'gift-exchange' mode. Therefore, the process of Yi Sha being published overseas, whether in Chinese or in translation, is also a demonstration of the minjian concept.

Based on his experiences of translating foreign poetry and being translated into foreign languages, Yi Sha has formed his own attitude towards translatability, which is diametrically opposed to Robert Frost's famous saying that 'Poetry is what gets lost in translation'. To Yi Sha, poetry is what is left in translation and translatability is a quality for good poetry. This belief derives from Yi Sha's minjian poetics that words, structures and facts (hardware) are more important than the linguistic beauty of the original language (software). Yi Sha insists that he would strengthen the 'hardware' of his poetry to make it more translatable. To Yi Sha, embracing translatability is not with the purpose of writing a 'world poetry' but an emphasis on his minjian poetics and communicating it to wider audiences of the world.

This research clearly illustrates that a case study combining critical biography with close reading, theoretical discussion and discourse analysis is an effective way to 
address both the polemic and the aesthetic dimensions of minjian. Through examining a broad range of literary texts and social activities of Yi Sha, I have provided a layered understanding of minjian as both a cultural position and an aesthetic ideal. By observing and chronicling a single poet over his creative career to date, I have been able to demonstrate that minjian is not merely a theoretical concept, but more importantly it is a poetic practice that continues to evolve and grow.

However, to acknowledge that minjian is a strategy to be adopted and an ideal to be realised through ongoing practice is also to acknowledge the potential variability and open-endedness of this research project per se. By identifying Yi Sha as the most representative minjian poet, I do not necessarily declare that he is the 'best' minjian poet, or even the most influential one. Rather, I seek to underline my perception that Yi Sha exhibits all the key features of minjian in both his writings and actions. Another poet might be more 'unofficial' in their stance, or more 'colloquial' in their poetics, but Yi Sha exemplies both of these minjian qualities in abundance and in equal measure.

The contribution of this study is, therefore, not the identification and the assessment of a fixed group of minjian poets, but rather an elucidation of what minjian entails and how it functions, through the case study of one representative minjian poet. Further research is needed, if the goal is to fully understand the variability and diversity of the minjian practice. For example, the major form of unofficial publication changes from people-run magazines in the 1980s and 1990s, to online poetry forums in the 2000s and to Weibo and Wechat in the 2010s. New forms of publication and dissemination of poetry will surely appear in the future with technological advancement. So will there also be new changes and development of Colloquial Poetry that warrant academic investigation.

Minjian poetry is important not only because it has become a frequently discussed topic and has exerted great influence over Chinese poetry in the first decade of the twentyfirst century, but also because it offers a new possibility for the development of 
contemporary Chinese poetry, a new aesthetics that diverges from the tradition started by Obscure Poets and followed by the Intellectual poets. It is a poetics that consciously distances itself from lyrical sublimity and keeps close to the reality of contemporary everyday life in China. It may be inaccurate to call these poets 'new', as they appeared in the 1980s, even earlier than the Intellectual Poets. However, they drew people's attention and became widely known, only after the 1999 Panfeng Polemic. In this sense, it is still understandable to describe them as a 'new' poetry group.

One distinctive feature of minjian is its inclusiveness in its shared identity among poets. Any poet writing Colloquial Poetry or mainly engaging with unofficial poetry activities could and, in many cases, would claim to be a minjian poet. This tendency underpins the vitality and popularity of the term minjian. However, although all poets who identify with the minjian concept can call themselves minjian, only the poets with all of the minjian elements are considered typical minjian poets. That is to say, minjian, when referring to poets, has an inner circle and an outer circle. Any poets, as long as they manifest certain minjian elements and identify with the concept, can be regarded as minjian poets and this cohort form the outer circle. Only those poets who demonstrate all the minjian elements — primarily Colloquial Poetry and unofficial stance — stay in the inner circle of minjian. Understandably, the list of minjian poets is not a fixed entity but a loose gathering of poets with minjian elements. Besides, even in an individual poet, these elements may change, and he or she may be a minjian poet at a certain period of time and fall out of the category at a later period.

Gender imbalance has been a problem for the minjian poets. There has always been male dominance in the circles of the minjian poets and Chinese avant-garde poets in general. This can be explained from two angles. On the one hand, male poets are usually more active in poetry activities and more daring at exposing themselves in poetry. A woman doing so would invite rumours that may affect her personal life. However, when a woman becomes active and touches upon taboo themes in her writing, her work catches more eyes than similar work by her male colleagues. Two female figures from 
the Lower Body Poets, Yin Lichuan and Wu Ang, are more conspicuous than their male peers in the group except Shen Haobo. On the other hand, there is arguably a misogynist tendency in the writings of most of the male minjian poets. However, Yi Sha himself does not see it as a problem. Whereas he often satirises and mocks women in his poetry, he also offends men and various groups of people. This can be considered a form of Yi Sha's deliberate subversion of political correctness. The gender issue of the minjian poets is a complex problem that involves a variety of social and personal factors and thus needs more investigation.

Seen from the perspective of class, the minjian poets in my research are all welleducated and should be considered 'intellectuals'. They represent a tendency among the intellectuals who choose to foreground the non-elite and the grassroots in order to challenge and compete with the mainstream and the official. However, compared with the real grassroots such as migrant workers' poetry, the minjian poets like Yi Sha paradoxically show their elitism. Yi Sha's emphasis on the construction of PostColloquial poetics, such as 'poetry of facts' and refined colloquialism, reflects his ambition to become a grand master of poetry rather than a mere representative of the grassroots. Towards the growing presence of migrant workers' poetry, Yi Sha's attitude is also ambivalent. He has selected some of their individual poems and promoted them through his 'New Poetry Classics', but has refused to admit the importance of the migrant worker poets as a group. To Yi Sha, the 'quality' of the poetry itself still outweighs where the poetry comes from. Grassroots poets like Yu Xiuhua can hardly belong to Yi Sha's minjian, because Yu, a poet from a rural village, came to prominence through the official channel, Poetry Periodical. Though she has some minjian characteristics, she is a minjian model in the eyes of the official. These also show the complexity of minjian in terms of class and status. Nevertheless, highlighting minjian's inclusiveness is still useful, especially as a reference to examine genuine grassroots poets.

As one of the most popular poetic term in the 2000s, minjian still retains its momentum 
today and perhaps will never disappear from the Chinese poetry scene. The Earthy poetics in the form of Colloquial Poetry still exists and continues to develop and challenge people's cognition of what poetry should be like. The tension between the official and the unofficial has been in China for decades and this general situation will not likely change in the near future. The official will go on defending its position as the aesthetic and institutional authority, while the unofficial will lose no opportunity to break through the official dominance and find its own way to survive or even occasionally become the mainstream. Under the influence of Yi Sha and other minjian poets, a new generation of post-1980 八零后 and post-1990 九零后 poets has grown up and are increasingly important: such as the Chang' an Poetry Festival member Xidu Heshang and many others included in Yi Sha's 'New Poetry Classics'. Though minjian is no longer a banner for them, they still retain strong minjian characteristics, and are noted for their minjian practice. In this sense, the significance of minjian in the 2000s cannot be exaggerated, for it brought to the foreground two important but neglected elements underlying contemporary Chinese poetry and its influence has already extended to the next generation. This thesis, in this sense, has made a meaningful and helpful contribution to scholarship on contemporary Chinese poetry.

This thesis took departure from the Intellectual-Minjian dichotomy and comprehensively examined the term minjian as both a cultural stance and an aesthetic orientation. By moving the study of minjian beyond the Panfeng Polemic and placing it in the broader context of contemporary Chinese poetry, I have concluded that minjian is not a theoretically constructed concept, but rather a cultural position and a poetic ideal rooted in sustained practice. While elucidating what minjian means in contemporary Chinese poetry, this case study also provides the first full-length critical biography of the poet Yi Sha in English.

The thesis started out with the general observation that the term minjian was ubiquitously used but poorly defined in contemporary Chinese poetry. By considering minjian as a practice that involves both strategic positioning and idealistic pursuit, I am 
cautioning against a definition that is too fixed or clear-cut. Scholarship should allow minjian the space to evolve and grow. It has transformed itself many times in the past and will surely continue to do so in the future. However, as a major presence that has witnessed numerous important moments in the development of contemporary Chinese poetry, minjian will keep its prominence on the Chinese poetry scene and will continue to function and exert its influence in the future. For Chinese poetry, minjian is and will be an inspiring term with its multiple and complex connotations. As time moves on, it will probably acquire new connotations in particular historical situations.

I have left the word minjian in pinyin throughout the thesis, untranslated. However, I have emphasised the importance of translation as a conduit between Chinese minjian poetry and world poetry, and documented how minjian poets like Yi Sha have embraced translatability. By leaving minjian untranslated I do not imply its untranslatability. To a certain extent, the entire thesis is an attempt at interpreting the term minjian, which is, in my view, the ultimate translation. I cherish the hope that by introducing minjian, a new poetic term, into English, the world's poetry and poetry studies have been enriched. I hope that, by translating minjian, something is gained, rather than lost. 


\section{Appendix: Yi Sha Interviewed by Liang Yujing}

Date: 15 April 2016

Place: Taoyuan dajiudian 桃园大酒店 (Taoyuan Hotel), Xi'an

\section{Topic One}

\section{The Naming of Minjian}

L: Today our interview will cover a few topics. Please say whatever you want to say and, if I have questions, I will let you know. It that Okay?

Y: Okay.

L: The main title of my thesis is 'The Making of Minjian 民间'.

Y: Is that the title of this interview or your thesis?

L: The interview is for my thesis. The subtitle is 'Yi Sha's Poetics and Poetry Activities', so let's begin with minjian.

Y: That's fine.

L: I encountered some difficulty when translating the word minjian, as it has multiple meanings. Finally, I decided to use the pinyin minjian. I have to make a concept.

Y: Sure. You say I'm making minjian, you are, too. Haha.

L: When minjian is discussed in China, there is a usual situation - all kinds of people talk about 'minjian', but digression often happens, as minjian has so many meanings. Once it is translated into English, its meaning is limited to the choice the translator makes.

Y: Even during the Panfeng Polemic 盘峰论争, this concept was not agreed upon by the poets involved-so we have started our talk?

L: Yes, of course.

Y: For example, someone (from the Intellectual side) raised a challenging question: 
How can Yu Jian 于坚 and Yang Ke 杨克 be regarded as minjian? You can even find the article.

L: How so?

Y: Because of the official institution. The institution of the Writers' Association 作协 (WA).

L: Oh, have the two been part of the institution?

Y: Yes, of course. Yu Jian was the editor of a theoretical journal affiliated with Yunnan Federation of Literature and Arts 文联 (FLAC). As you know, the WA of Shaanxi is a 'Big WA', but Yunnan only has a 'Small WA', that is, the WA is subordinate to the FLAC and the two belong to the same work unit of the official system. Working for the FLAC entails that one is in the institution.

L: I see.

Y: Yang Ke worked for the magazine Zuopin 作品 (Literary works), affiliated with Guangdong WA. He was one of the editors a few years ago but now the editor-inchief. Hence the challenge from the 'Intellectuals': How can they be considered minjian? According to them, if you claim you are minjian, you must be in opposition to the official, right?

L: Right.

Y: They were in fact creating an imaginary opponent, for we didn't call ourselves minjian. Though you said I made minjian, the fact was, Wu Sijing 吴思敬, a professor at Capital Normal University and the host of the Panfeng conference, incidentally named it. Of course Intellectuals were called 'intellectuals', as they selfclaimed, in the articles by Xiao Kaiyu 肖开愚 and Ouyang Jianghe 欧阳江河, 'Intellectual writing'. Xiao and Ouyang first proposed this term, I guess.

$\mathrm{L}$ : 'Intellectual' is their self-naming?

Y: Yes. They named themselves so.

L: In Qingxiang 倾向 (Tendency)?

Y: Yes. So, at the conference, the two sides began to quarrel, but how did you name them? The host said, 'one side are the Intellectuals, and the other side?' We should bear in mind, at this stage, the Minjian poets had not been named yet and the group 
was still largely known as Colloquial Poets. Before the conference, both sides had already some pretexts, as a result of the recent poem collections each published. On the Intellectual side, Cheng Guangwei 程光伟 edited Suiyue de yizhao 岁月的遗 照 (A portrait of years gone by), which included only two Colloquial Poets, Yu Jian and Han Dong 韩东, and each only with two poems. By contrast, each Intellectual Poet had more than ten poems selected. A great difference. As a response, the socalled minjian side — should be the Colloquial side, edited 1998 Zhongguo xinshi nianjian 1998 中国新诗年鉴 (1998 yearbook of China’s new poetry). This collection was more inclusive and deliberately included some Intellectual Poets, although not necessarily equal space. On its cover clearly in print: 'In our pursuit of art, we insist the real, eternal minjian standpoint' 在艺术上我们秉承：真正的永恒 的民间立场.

L: Was it the first time that the word minjian was used in such a context?

Y: Yes, indeed. That was why Wu Sijing said, 'Since you want to take the real, eternal minjian standpoint, let's simply call you the “Minjian group”民间派.' Such was the case- - in fact it's a concept imposed on us.

L: But in the past, though there wasn't the word minjian to group you together, you were still loosely connected with each other?

Y: Indeed. I wouldn't deny that, in China, poets of similar styles get along better.

L: Did you have a group name then?

Y: No group name, to be honest. But for example, among the 'Third-Generation' poets, there were already some groups composed of all Colloquial Poets, like Tamen 他们 (Them) founded by Han Dong, right?

L: So before this, the name 'Colloquial' had appeared?

Y: In the conversations of Han Dong and Yu Jian there had appeared the saying 'speaking for Colloquial Poetry', in their conversation in Taiyuan. The best and most representative poets in Not-not 非非主义, like Yang Li 杨黎, also belong to the Colloquial category, right? In fact, among the Third Generation, it was quite clear which group was colloquial and which was anti-colloquial. The Macho Men 莽汉 
主义, say, was definitely colloquial, like Li Yawei’s 李亚伟 poetry. So there were generally some colloquial groups, and some others slightly ambiguous.

$\mathrm{L}$ : Which ones, can you name them?

Y: For instance, typical Intellectual magazines, like Tendency (1989), were founded later than Them (1985) and Not-not (1986).

L: So Them and Not-not can be regarded as two origins of Colloquial Poetry?

Y: I heard—I didn't experienced but heard—that in the 1986 Youth Poetry Meeting 青 春诗会, Yu Jian and Han Dong were among the participants—not all of them were Colloquial Poets, for example, Zhai Yongming 翟永明 was not and Che Qianzi 车 前子 was a bit colloquial. But because there were Yu Jian and Han Dong, their anthology published after the meeting, with Yu Jian as the first poet, looked as if Shikan 诗刊 (Poetry Periodical) was supporting the Colloquial. Rumour has it that, in 1987, Poetry Periodical said, since there were a lot of Colloquial Poets the last year, this year they would include more non-Colloquial poets- 'Intellectual' had yet to appear then.

L: Haha.

Y: Then the 1987 meeting included Ouyang Jianghe and Xi Chuan 西川. That batch was obviously non-Colloquial. I heard from Yang Ke that it was probably Ouyang Jianghe who proposed to Xi Chuan in their hotel room, 'We have to find a name.' Since 'Colloquial' had been known to all, they 'had to find a name'. It seemed they had mention 'Intellectual writing' in their room. Thus all the stories have pre-stories.

L: Well, Not-not of Sichuan and Them, which is earlier?

Y: Of course, Them is earlier. Them seemed to be founded in January 1985 while Notnot was in 1986. One year earlier.

L: I see.

Y: Then, in the 1990s, the 'Intellectual' appeared - they, more pedantic like scholars, liked writing formal theoretical articles. You felt they kept consolidating their theoretical foundation throughout the 1990s. When they compiled an anthology, they usually had a fixed list of twenty or thirty poets, a thing they kept doing. On the Minjian or Colloquial side, they somewhat became weak, no longer so popular as in 
the 1980s. It seems, after Hai Zi 海子, some original Colloquial Poets didn’t write Colloquial Poetry anymore, like Liang Xiaoming 梁晓明 in Hangzhou and some Shanghai poets, who used to be Colloquial Poets, how come they didn't write Colloquial anymore? Yu Jian's poetry became more and more intellectualised, an ‘intellectualised' Colloquial Poetry.

L: He has changed since then?

Y: Yes, since 1989. And Han Dong focused on writing fiction. So I think the Colloquial Poetry of the Third-Generation became weak in the 1990s. After 1989, those 'Intellectuals' rose to fame by promoting Hai Zi. In my view, they 'carried the coffin for Hai Zi’ 抬棺, for Hai Zi had some connection with them during his life.

L: Hai Zi and Xi Chuan were classmates.

Y: Ah yes. After Hai Zi's death, they all thought they were relatives of Hai Zi and promoted themselves by this chance, so they looked as if standing in the spotlight. However, while the old Colloquial Poets on the Minjian side became weak, I appeared with a new, more vigorous Colloquial Poetry, more postmodern than $\mathrm{Yu}$ Jian's and Han Dong's poetry in the 1980s, like 'Che guo Huanghe' 车过黄河 (Crossing the Yellow River) and 'Jiejiebaba' 结结巴巴 (St-stammering, ststuttering).

L: In which year did you make your debut?

Y: It was a gradual process. For instance, 'Crossing the Yellow River' did not get published for a long time, until recently it appeared in a retrospective exhibition in Shan Hua 山花 (Mountain flowers). It had never been published in an official magazine before.

L: But people had known the poem.

Y: Yes, through unofficial magazines and the Internet, it became more and more famous, like Cui Jian 崔健, the pop and popular singer who can never appear on China's Central Television. Yes, 'Crossing the Yellow River' became well-known in a gradual way, so did 'Starve the poets'. People had already known it when it appeared in Poetry Periodical, No. 8, 1993. Poetry Periodical was then still influential, making it well-known overnight, thus I became widely known due to that issue. 
L: That was August 1993.

Y: Many people were terrified, astonished and felt unprepared for its appearance in Poetry Periodical. Consider this: how can such words as gouride 狗日的 (dogfucked) appear in Poetry Periodical?

L: Haha.

Y: Right? Then, the next year, 'St-stammering, st-stuttering' appeared in Renmin Wenxue 人民文学 (People's literature). In fact, the two poems had exerted great influence through unofficial magazines before this. Later they became more influential.

L: Did you write that poem at university?

Y: 'Crossing the Yellow River' was written at university, while the other two were written after I came back to Xi' an. In all, that's the origin of what you called 'minjian'.

L: Yes.

\section{Topic Two}

\section{The Connotations of Minjian}

Y: In the Chinese context, the word opposite to 'minjian' should be 'official', but we often put it in opposition to 'Intellectual'. It's hardly a scientific opposition.

L: That's right.

Y: Those 'Intellectuals' also felt unfair: Aren't we also minjian? They ask. In the grand ecological structure of the Chinese poetry scene, of course they are also minjian. They don't agree blindly with the institution of the WA, which sometimes draws them in and sometimes pushes them out.

L: And when Bei Dao 北岛 and his fellows founded Jintian 今天 (Today), they were also typically minjian.

Y: Of course, minjian. Today is the first unofficial literary magazine in China.

L: Here is the binary opposition of minjian and official, but if we understand minjian as folk literature, its relationship with intellectual literature is also-

Y: That's interesting then. 
L: That would be complicated.

Y: Let me explain this in this way. In response to the later development of Colloquial Poetry, we name it 'Post-Colloquial' 后口语—we call the Third-Generation Poets in the 1980s 'Pre-Colloquial' 前口语 and the later poets from me onwards 'PostColloquial'-According to the development of 'Post-Colloquial', including what you can see in 'Xin shiji shidian' 新世纪诗典 ('New century poetry classics', or 'Xin shidian' in short, 'New poetry classics', NPC), you will find the minjian characteristics are becoming more and more discernible. It has become a poetry window to witness the Chinese minjian society and the minjian temperance of these poets. For example, since the appearance of the NPC, we have found real peasant poets for the first time. The NPC published two real peasant poets, not those pseudopeasants who grow up in the country, get educated in the city and then write about the countryside. One is a fruit farmer and the other grows crops. And they write poetry, too. These are real minjian poets, right?

L: Yes.

Y: Then, because of a movie, there is an obvious phenomenon: the migrant worker poets 打工诗人. In fact, the best migrant worker poets are all included in the NPC, not those famous ones like Zheng Xiaoqiong 郑小琼. There is a Tianjin-based poet A Wen 阿文, who remains a migrant worker now. ${ }^{304}$ In my view, the word minjian, though not our own self-naming, becomes more and more influential, especially among the Colloquial Poets. I don't believe there were such a Colloquial Poet who would tell himself daily: 'I'm a minjian poet', but this word seems to have an intrinsic affinity with Colloquial Poetry.

L: Indeed.

Y: As for later Chinese Colloquial Poetry, I think its minjian-ness gets increasingly stronger.

L: That is to say, 'colloquial' and 'minjian' have merged.

Y: Yes. And it also carries the connotation of folk literature, because it is close to the

${ }^{304}$ Zheng Xiaoqiong (b. 1980), often regarded as the representative of Chinese migrant worker poetry, became a famous poet when she was a migrant worker but she has now changed her job to a literary editor. 
oral language, close to the slangs of the common folk, popular slang, right? Such as xiehouyu 歇后语, the idiomatic puns in everyday language, very close to the common folk.

L: The initial problem I encountered is, I have to define what minjian is. If I use the pinyin minjian to signify it like using an irrelevant sign ' $\mathrm{ABC}$ ', then what does ' $\mathrm{ABC}$ ' stand for?

Y: To make it clear to others, it can probably be explained like this: In fact, there are three forces, rather than two, on the Chinese poetry scene.

L: Ah yes, including the official.

Y: Right, one is the official. With regard to the official we'd better not be too simplistic in our judgement. We should only take into account one's poetic taste, no matter whether he is in the institution, regardless of his profession or how he makes a living. If his poetic taste is institutional, following the political propaganda, mainstream, in the vein of the main melody, then it is official poetry.

L: Yes.

Y: For instance, at the anniversary of the CCP, Poetry Periodical will publish a poem as its headline to celebrate the occasion. Even at the anniversary of anti-fascism or the Nanjing Massacre, there will be such a poem. No matter how righteous you are, as long as your piece comes from a non-literary inspiration, I think such a work is official or institutional literature. I refer to one's poetry, rather than whether he is in the WA. A poet in the WA may write very minjian poetry. It's very likely.

L: Yes.

Y: Now, let's talk about the so-called 'Intellectuals'. Though they called themselves 'intellectuals', I think you can distinguish the Chinese concept of 'intellectuals' from the western or internationally standard concept of the word. In fact, our intellectuals cannot bear the responsibility of 'intellectuals' in its modern sense. Ours are $d u s h u$ ren 读书人 (book readers), a concept of xueyuan 学院 (academy), a xueyuan taste. What they called 'Intellectual' is scholarly, academic temperament, or some fuzi 夫 子 (an ancient Confucian scholar or pedant) temperament, not real intellectuals. On 
my first visit to Sweden - the festival invited Yu Jian, Yin Lichuan 尹丽川 and me- the one who gave us the opportunity was a female poet, who had a friend working for the Royal Swedish Opera as a playwright, a professional playwright of a high social and cultural status. Through the interpreter, Yu Jian asked him, 'Since you have read Yi Sha's and my poetry, what do you think is our difference?' Before he could reply, Yu asked again, 'Is my poetry more intellectual?' Perhaps Yu had then felt, compared with me, he was more intellectual. That was 2002, when we were still fighting with the 'Intellectuals'.

L: Haha, so he ...

Y: That man replied, 'In fact I think Yi Sha's poetry is more intellectual; yours, in my view, carries a lot of historical concerns.' That was his comment on our poetry, saying mine was more intellectual. I immediately understood his meaning, though he didn't explain. What is intellectual? A critical spirit, right? A challenging spirit.

L: Yes.

Y: In this regard, my poetry is more obvious than Old Yu's, isn't it?

L: Yes.

Y: When he said so, I understood, but because I had to show respect for my old brother, I didn't say it clear. The fact is, what we called 'intellectuals', the Chinese 'Intellectual Writing', is not the concept of that intellectual. You can't find much challenge. You can't find his criticism of the society, his responsibility, can you? Not very obvious. They simply cling to their xueyuan taste, the Chinese xueyuan taste, like Zang Di 藏棣—Zang's correction was actually their original meaning—shortly after the Panfeng Polemic, Zang called for 'boshi xiezuo' in Nanfang zhoumo 南方 周末 (Southern weekly).

L: What xiezuo?

Y: Boshi xiezuo 博士写作 (doctoral writing)

L: Oh, I see.

Y: It means you are qualified to join his 'doctoral writing' when you get the degree. Then no one responded to him- he put himself to shame.

L: Haha. 
Y: Right? He named it 'doctoral writing'. No one even bothered to criticise him. In fact, what we criticised was just their thinking, how should I say, a superiority of knowledge.

L: Like the Chinese intellectuals who look down upon ...

Y: Yes, yes. So I think there are three forces competing with each other.

L: As for the minjian standpoint, Dian Li, an American scholar, wrote an article on the Panfeng Polemic. By comparing the manifestos of the 'Intellectual' and the minjian sides, he found they shared a common ground, that is, 'independent' from the official. If we understand minjian as 'unofficial', do the two sides agree with each other on this point?

Y: Umhh ... In my opinion, as I said about the 'Intellectuals', their concepts are not related to real intellectual. I don't think the relationship between the 'Intellectuals' and the official is in opposition to each other. In terms of obtaining resources, the 'Intellectuals' benefit more from the official than the Minjian poets do. The official, who can accept the 'Intellectuals', can hardly accept Colloquial Poetry. For instance, let me see ... The official still thinks of itself as a hall of great elegance, like Poetry Periodical and People's Literature. It's suitable to place an 'Intellectual' poem in such a hall, isn't it?

L: Yes.

Y: Perhaps they wouldn't put it in the headline, which is usually something big and great, a poem for a political festival. But they would put it in the second or third place, because it looks decent to place such a piece of furniture there. But if they put our poetry there, they would find it unpleasant, like furniture too rough and indecent. Thus my view is, there is not a clear opposition between them, unlike Bei Dao and the Misty Poetry, Today, who stood in clear opposition to the official, at least confrontation. The 'Intellectuals' are not like that, though they were also persecuted due to the publication of Tendency. But that was because of the identity of Huang Beiling 黄贝岭 rather than the contents of Tendency itself, right?

L: Yes.

Y: Because the police knew Tendency was funded by Huang Beiling, rather than how 
rebellious its contents were. I think it's difficult for foreigners to find this out. In fact, for example, Confucianism and Taoism, which one do you think the ruler prefers? The ruler certainly prefers Confucianism. He hopes that you care for the fate of the nation for him, that is, for the emperor. If you care too much, he can delete your words and make them unknown to the public. If you play too much of such a role, he can label you as a rightist and persecute you, but he still wants you to care. On the contrary, he dislikes Taoism, for he can't control you if you behave like an immortal, indifferent to worldly affairs. This is a bit like minjian and the Intellectual. The 'Intellectuals' always act like men of letters but were communicable with the official, though the official doesn't quite like them. We knew this, too, in our time of danger. I was once watched after I came back to Xi' an, and I heard how the agent said about us, isn't it interesting? The agent who watched me never appeared before me but he would turn to the 'old sportsmen' 老运动员 (those who suffered continuous political persecution during the Maoist era). Then Shen Qi 沈奇 was also being watched, one who was watching both him and me asked him-

\section{L: Someone from the National Security Department?}

Y: Of course. He asked Shen, 'How come Yi Sha's poetry looks sometimes reactionary and sometimes erotic?'

L: Hahahaha.

Y: He was confused. If you are merely politically reactionary, he may simply arrest you or determine your nature. What was embodied in my poetry actually vexed him, as he thought it looked sometimes roguish, sometimes erotic and sometimes like a serious revolt - it became complicated to some extent. In fact, our writing is a more complicated one, not pure antagonism such as Bei Dao's - of course he changed a bit in his later career-at least in those years, they looked a bit like antagonistic writing.

\section{L: That's right.}

Y: Antagonistic writing will make things simple. That is, I fight against you. If so, the quality of my own writing will greatly decline. However, I believe-for instance, 
they wanted to arrest Chen Dongdong 陈东东 due to his connection with Huang Beiling, but could the spy who watched Chen find anything bad in Chen's poetry?

L: Haha.

Y: Nothing suspicious, right? First, he wasn't able to understand the writing. Then, even if he understood something graceful in it, the official wouldn't feel offended. It's even a decoration. Since the headline and main melody have been determined, the second and third poems are usually a display of profound knowledge or beautiful landscapes, which is in fact a decoration, showing the entire country is full of happiness and cultural prosperity. Everything goes well. That's my viewpoint. I think Dian Li has missed this point.

L: So my definition of minjian includes: 1. Being 'Colloquial' in poetics; 2. Being unofficial in position. These two aspects.

Y: Yes, yes. One more thing to add: it's not only 'unofficial' but 'non-academic' 非学 院 or 'anti-academic' 反学院. I myself would call it 'anti-academic' in its poetic taste.

L: Yes.

Y: If you say 'anti-intellectual', the foreigners will be confused again: Are you against the challenging spirit of the real intellectuals? No. We are against the academic taste, the taste of the Chinese academy.

\section{Topic Three}

\section{Foreign Influences over Minjian}

L: There is another aspect: the relationship of minjian and foreign cultures. Does minjian implies a native consciousness?

Y: I think this point was misled by some critics. During the Panfeng Polemic, Yu Jian once got angry and called me, saying a critic simply labelled us 'minjian' as narrow nationalists, or without 'narrow', just nationalists, so we stood for nationalism while the 'Intellectuals' stood for what I've forgotten. In a nutshell, we were narrow while the other side was open-minded to international cultures. In fact, I think this is 
completely not the case. You can find the source: the earliest one to say that we 'grew up drinking wolf milk' 喝狼奶长大 was Xiao Hai 小海 from the 'Them' group. Later, Han Dong repeatedly mentioned these words. That fact is, our generation all grew up drinking wolf milk. As Gao Xing 高兴 said, 'What would Qin Bazi’s 秦 巴子 and Yi Sha's writing become without foreign literature?' The influence of foreign literature over us, the elements we learned from foreign literature, is no less than the so-called 'Intellectuals'.

L: But you learned differently from foreign literature.

Y: Yes and it's more interesting that-for example, I translated Charles Bukowski in 1995-we, interested in different foreign poets, selected different sources from foreign literature. Obviously, from 1990s to the Panfeng Polemic, among the favourite names of the so-called 'Intellectuals', the top three were ...

L: Joseph Brodsky?

Y: Umh ...Brodsky couldn't make it to the top three, which surely were Rainer Maria Rilke, Jorge Luis Borges, and the third one, Friedrich Hölderlin. Because Hai Zi loved him, right?

L: Why did they love these three?

Y: For whatever reasons, the first name in their articles must be Rilke. You can see this is their list. If on another group's list—-because Bukowski became famous later in the Chinese context - the first is Allen Ginsberg, this group must be on our side. The fact is, we were simultaneously influenced by foreign literature, but we were selective in the course of being nourished. We received different nourishment and we, the Colloquial Poets, learned from those poets closer to us in time, such as Allen Ginsberg and Philip Larkin - they are among the favourites of the Minjian Poets. This point, I think, is misunderstood by foreigners. Certainly, our localisation is better than the 'Intellectuals' but this localisation is not 'rednecks writing about the old earth' 老土写老土, not the way those Shaanxi writers write about Shaanxi. We write about China's reality after absorbing the advanced elements of western colloquial poetry, and now China's reality becomes more and more obvious in the works of the Post-Colloquial Poets, because their weaponry is strong, good at 
depicting this reality.

L: They use the foreign equipment.

Y: Yes, foreign equipment, that of the US special forces, to write about China's reality. So you will see the truth and texture of China's reality under the pen of the Colloquial Poets. Sometimes the 'Intellectuals' also touch upon China's reality but you feel as if they wear a condom in writing.

L: Haha.

Y: I mean, it's not real. Later we coined a word siwa jiao 丝袜脚 (feet in silk stockings), not the unbound feet but a pair of feet forever wearing silk stockings, which feels not real, like second-hand goods from a middleman, not the texture of China's reality you can touch. So I think the situation is not that one side is rooted in the native and the other side learns from foreign resources. In fact, we, mostly born around 1968, all lived in the same China. In the 1980s, the barbarous age of copyright ...

L: You both sides are almost the same age?

Y: Yes, much the same age. We all fell on the uncopyrighted literature in translation, reading the same material in the same age, only our taste and selection are different. For example, the favourite poet of the Colloquial Poets - I just mentioned 'Them' the favourite poet of 'Them' is Robert Frost.

L: Oh, I see. Haha.

Y: It's quite clear, mild colloquialism, right?

L: Yes.

Y: Every group has its own favourite. For us 'Post-Colloquial', namely the more provocative colloquial poetry, we like Allen Ginsberg, then this Bukowski I discovered - they are our masters. For the mild colloquial poetry, they like Robert Frost and Robert Bly. Each group has its specific sources or, what can I say, idols. Haha.

\section{Topic Four}

\section{Colloquial Poetry}


L: Now let's talk about Colloquial Poetry, namely your poetics. On this topic, Tang Xin 唐欣 wrote a book Shuohua de shige 说话的诗歌 (The speaking poetry), based on his $\mathrm{PhD}$ thesis. I've read his book, in which he clearly narrates the development of Colloquial Poetry, including its early poets. However, I find he is not so clear in the concept of this poetry. It seems he talks about it as colloquialised poetry but seldom touches upon the nuances in its poetics. So my initial question is: What is Colloquial Poetry?

Y: Have you read my 'Analects of Colloquial Poetry'?

L: Not yet. Not a long piece, right?

Y: Not long, more than ten thousand characters, written after I sent you my books.

L: I have probably seen it online.

Y: It's the top item on my blog. I've tried to explain the theory clear in it. It consists of fragmentary pieces. You can have a look.

L: Okay.

Y: I don't think it's so simple. As I say in it, Colloquial Poetry is not colloquialised poetry, or not merely so. Perhaps it was so at its beginning.

L: Like the 'Pre-Colloquial' in your words.

Y: Yes. 'Pre-Colloquial' may look like this. Tang Xin, perhaps due to his age and his practice in the $1980 \mathrm{~s}$, focuses more on the early period.

L: I see.

Y: Why did I say it was not colloquialised poetry? For instance, I believe the earliest and the best Colloquial Poem is by Wang Xiaolong. I insist that Colloquial Poetry originated neither from Han Dong, or Yu Jian, but from Wang Xiaolong 王小龙, who wrote a poem in 1982, 'Jinian' 纪念 (Commemoration), to commemorate his father and that was the beginning of Colloquial Poetry.

L: I see.

Y: Other earliest Colloquial Poems were all dated as written in 1983. Although there seemed to be only a difference of one year, during that period, one year was not minor at all. Sometimes poets imitated a poem published one year ago, the one to take the 
first step (was the one who began the new way). A similar case can be found in the history of modern literature: between Guo Moruo 郭沫若 and $\mathrm{Hu}$ Shi 胡适, who was earlier in writing vernacular poetry? In fact, Guo was at a disadvantage, as his collection was delayed publication by Taidong shuju 泰东书局 for seven months. A seven-month delay made it appear later than Changshi ji 尝试集 (Experiments) by $\mathrm{Hu}$ Shi.

L: Haha.

Y: Later I found that Experiments was still earlier even if there wasn't a seven-month delay of Guo's collection. However, in terms of poetry, Hu Shi was not necessarily the earliest (to write poems in the vernacular in free verse). For example, Guo's poetry in free verse was published in 1916, earlier than Hu's publications. Thus, I don't consider one year's difference, at an early stage, was a small one. As you can see, the early Colloquial Poetry still bears the traces of lyricism, as shown in Wang's 'Commemorisation' about his father, in which he used metaphors such as 'silent palms' 沉默的棕榈 and something else along with the obvious traces of colloquialisation, like 'got up at midnight to buy brown sugar' 半夜爬起来买红糖. At the early stage of development, probably colloquialisation was sufficient. However, at a later stage, Colloquial Poetry should contain not only external colloquialisation but also intrinsic colloquial thinking, or colloquial poetic thinking, a way of thinking related to 'poetry'. The way a Colloquial poet thinks about a question and views the world is different from the non-Colloquial poets. For the nonColloquial poets (lyrical poets and image poets 意象诗人), the inspiration is only his accumulation of material. For the image poet, he collects materials from the inspiration and develops it into an image to represent the world. For the lyrical poet, he purifies the materials in his experiences in order to express his emotions. But for the Colloquial Poet, the moment he gets the inspiration, he makes a connection with the materials in his experiences. That moment becomes his decisive snapshot which in turn is transfixed in his poetic lines. Most importantly, the poet needs to have a good judgement and is able to grasp key image like a cameraman. That moment defies thinking but decides if you can be a good photographer. It won't allow you 
five minutes to think the matter through and the shutter has to record what is there at that moment. What comes out of the process is the surfacing of what has been accumulated by the poet in his inner world aesthetically. For me, Colloquial Poetry has already reached such a ...

L: Is this your own opinion?

Y: Yes.

L: Post-Colloquial?

Y: Yes, Post-Colloquial.

L: Then does Xu Jiang's 徐江 'modern poetry' mean the same?

Y: As for Xu Jiang's 'modern poetry', his problem is the vagueness not only in definition but also in classification. Both are unclear. For instance, in terms of techniques, I think poetry can be divided into the colloquial, the lyrical and the image poetry, but which one is Xu Jiang's 'modern poetry'?

L: Right.

Y: He has never defined it clearly. He only took 'new poetry' and 'modern poetry' into consideration. In reality, not many people understand what he refers to. Some keep using the concept of 'new poetry'. So my intension here is-I would enrich his theory-I think 'modern poetry' should include Colloquial Poetry, the modern lyrical poetry, which I have to narrow it down, for there is old lyrical poetry - and the image poetry. These three constitute 'modern poetry' in Xu Jiang's words.

L: Does your 'image poetry' refer to those like 'Intellectual' poetry or something else?

Y: Yes, the 'Intellectual Poetry' is basically image poetry. In their later period, they invented the so-called xushi 叙事 (narrative poetry). Sun Wenbo 孙文波, who found 'narratives', thought of it as a treasure. But since Wang Xiaolong, the Colloquial Poets have been always narrating, right?

L: Yes.

Y: To a Colloquial Poet, there is no poetry without narrative, an innate feature. Sun found it so belatedly but got so excited about it. That's why we poured scorns on them. Why did they regard 'narrative' as a treasure? Because, technically speaking, they used to write image poetry with lyricism and they didn't know about the 
technique of 'narrative'. Thus they were very excited to find poetry could be narrative. After they found 'narrative', their poetry was no longer pure image poetry in my eyes. You can see the style of Tomas Tranströmer. We call it 'post-symbolism' 后象征主 义 or 'post-imagism' 后意象主义, namely the extraction of images with high purity. In retrospect, which Chinese poet is the closest to Tranströmer in style? Still Bei Dao. L: Yes.

Y: Still Bei Dao. There is no such a poet in the 'Intellectual' group who writes such a poetry with highly pure images.

L: They often add lyricism to their poetry.

Y: Yes, so I call them zayu shi 杂语诗 (mixed language poetry).

L: That's interesting.

Y: They increasingly tend to produce mixed language poetry, which would contain images, lyricism, even discussion, retorts and interrogation. They seemed to admire such a complexity-I'm trying to describe them as accurately as possible. Now Xi Chuan proposed bu fenhang 不分行 (No line breaks) again.

L: Is 'shishi de shiyi' 事实的诗意 (poetry of facts) a term coined by you?

Y: Yes.

L: Have you coined other terms except this one?

Y: Yes, I have coined several terms-I'm good at coining terms, then those theorists take them away. I often find, oh, how come this term has been used without crediting me. One is 'poetry of facts', very influential. This term is primarily used among the Colloquial Poets, who regard it as a criterion. Another term, mainly used by the theorists, is jiwu 及物 (reaching the object or transitive), also my coinage: 'reaching the object' or not. Just now I said the 'Intellectual' writing has no texture, because their language, their words 'don't reach the objects'. Later there appeared a term jiwu xing 及物性 (feature of reaching the object; transitivity), that is, there must be a connection between your words and the objects they signify. To let the reader touch the objects through your words. So this term is often used by theorists, haha.

$\mathrm{L}$ : Then what is 'poetry of facts'?

Y: In my view, 'poetry of facts' is-have you noticed such a phenomenon? Even if a 
person has never written a poem or read much poetry, you still feel he lives a poetic life- have you seen such a person?

L: Yes.

Y: He himself is a poem. I mean those people who we think are interesting, funny, even a little romantic and over-spiritual—such a state of life is what we call an instinctive poet, even though he never writes a poem. This is what I called 'a fact': there must be a fact before poetry happens. The 'poetry of facts' I emphasize is, you have to make me see the fact before seeing the poetry growing out of the fact. That's just what I mean. Because Colloquial Poetry is one that reaches the objects. If you jiwu, the relationship between you and the objects is what your poetry should show. When you put the incidents, materials and objects before me, can they constitute poetry? I will make a judgement. This is what I say whether this fact is poetic. If the fact is poetic itself, then your poetry does not come out of your language alone, right?

L: Yes.

Y: Because the fact you talk about has produced poetry itself. Or the person, the object you write about - it has produced poetry itself. Then your language is to reproduce this 'poetry of facts' and your language is not created out of nothing. As you know, an old hand in writing often deceive some inexperienced readers. For example, the story he narrates is not poetic at all, but he can use some language tricks, say, words like flowers and autumn leaves, then the inexperienced readers will be fooled, considering them as poetic language. I mean, when you have a criterion like 'poetry of facts', such a fraud will be exposed. He conceals his ignorance about life with cliched poetic language, making poetry with language. He, who finds no inspiration in life, is unable to capture real poetry in life, so he has to make it up with languagewith clichés from traditional poetic language. In fact, I think there are still such poets nowadays, let alone frauds, poets who fool inexperienced readers with a collage of words.

L: I remember Simon Patton wrote about you in an online article that you can talk about poetry ceaselessly, seven days a week and twenty-four hours a day, haha.

Y: He wrote about his journey in the northwest, from Lanzhou to Xining. It seemed 
then we did talk about poetry every day and I was the most enthusiastic one, more enthusiastic than now when I was thirty-five or six, talking about poetry endlessly.

\section{Topic Five}

\section{Unofficial Stance}

L: At a New Zealand Asian Studies conference, I gave a presentation on your poetry and read 'St-stammering, St-stuttering'. The audience's responses were warm but they asked a number of question regarding those concepts like minjian and 'unofficial'. They asked what 'official' is.

Y: But they were interested?

L: Yes. If you think you are 'unofficial', then what is 'official'?

Y: I allow myself to be tolerant. For example, both Yu Jian and Yang Ke were once my friends when they worked for the institution. As we all grew up on this land, I think one's profession-especially in our time it was called 'assigning jobs to university graduates', unlike your time when there is a two-way choice. In our time, a graduate didn't have many choices about his work unit. No one should be blamed for his assigned job.

L: Right.

Y: But what I mean is, 'official' refers to the official criteria in writing.

L: The aesthetic criteria.

Y: Yes, aesthetic. In fact, they don't have aesthetic criteria. Theirs are non-aesthetic criteria, still the intervention of politics in literature, literature used by politics.

L: Then do you oppose the official institution such as the WA and the Lu Xun Literary Prize 鲁迅文学奖?

Y: I definitely oppose them but ...

L: But you won't have a head-on confrontation with them.

Y: Never. It depends on the circumstances. I'm not a troublemaker who shouts the slogan every night: Down with the WA! You know? The first article that appealed for 
dissolving the WA was written by me, published in Wenyou 文友 (Friends in letters) in 1998. That magazine was ordered to stop publication for three months.

L: Haha.

Y: That also shows my normal state of being. If I have the right and the power to speak, perhaps I will make such comments, but I'm not the person who shouts the slogan 'Down with the WA' online every morning. On occasions when I experience a conflict or someone violets my principles, or there is a damage to my reputation, I will refuse. To be frank, this is in fact a relationship needing to be dealt with carefully. Going too far either way will make you an alienated person. If you seek the official patronage, affiliated with it, getting closer to it, you will probably be alienated. If you fight against it every day, you might betray your role as a poet, turning into a goodfor-nothing with merely a reactionary slogan.

L: Just as Harold Broom said about Allen Ginsberg.

Y: Ah yes. I mean you shouldn't play the role too indulgently. I also carefully deal with such a relationship. Similar cases include not only Broom's words about Ginsberg but the debate between Milan Kundera and Václav Havel. Definitely, I want to become Kundera rather than Havel who plans to run for the presidency in the future. Thus, everybody follows his own plan of life. Liu Xiaobo 刘晓波 used to be my teacher. He follows his own road, with which I don't have any problem. He once said, 'Don't get close to politics.' He educated us like that, saying Chinese writers have a bad habit of interfering in politics. He cited Joseph Stalin's words, 'Don't interfere in politics; politics will interfere in you.' Later he didn't behave like that and I won't blame him for betraying his own words. He taught me such values and it's enough for myself to believe in it. People have different plans for life.

\section{Topic Six}

\section{Official and Unofficial Publications}

L: Another question is: How has your poetry been disseminated? I mean, from the very beginning to the later period. Of course, it's a big question. Let's talk about it step by 
step. How did that begin? Normally a person must join the WA, right? And submit works to the official journals and receive awards?

Y: Yes. At the beginning, I was a literary lad. I always remember the publication of my first poem-I had thought my first poem was the one I wrote and published when I was seventeen. However, recently in the Wechat group of our former high school classmates, a female classmate provided me with important information by displaying a letter I wrote to another male classmate at thirteen, in which there was a poem. She and the male classmate are close friends, so he gave the poem to her.

L: Haha.

Y: She provided evidence that I wrote a poem at thirteen but I don't remember if I wrote any poetry earlier. So I was a literary lad at an early stage and had my poems published in many journals for high school students. Then there were Yuwen bao 语 文报 (Language and literature paper), Shaonian wenshi bao 少年文史报 (Literature and history paper for young adults/children) and Shaonian wenyi 少年 文艺 (Literature \& arts for young adults/children). Before university, I had published some twenty poems in these publications. At the university stage there were journals for university students, like the 'Poetry garden for university students' 大学生诗苑 in Feitian 飞天 (Apsaras), a column in Apsaras, which had an influence greater than Poetry Periodical over the university students. In most cases, like people in society, I submitted to those literary journals for adults, but was often rejected. In retrospect, I think it was probably related to my Colloquial Poetry.

L: Haha.

Y: And my success rate got lower and lower. It was higher when I wrote gracefully. But when my writing got more colloquial and vulgar, it became lower. I published some thirty poems in total during my university years.

L: Were you already associated with other poets in university?

Y: I associated with mostly student poets of other universities. After graduation, I experienced the darkest period of publication.

L: How long was it? 
Y: I fully understood my country's fate is my fate. From 1989 to Deng Xiaoping’s 邓 小平 'Southern Tour' speech in 1992 .

L: Oh, such a period.

Y: Or it includes the full year of 1992, for there was a transitive time after the speech, right? It was the politically 'dark age'. You were too young to feel it?

L: I was in Grade One at primary school in 1989.

Y: Too young. You didn't have any feeling. I coined a term for it, 'China's political vacuum' 中国政治的真空期, oh no, 'cultural vacuum' 文化的真空期, from the 4 June Massacre to the 'Southern Tour' speech, to the end of 1992, including the transitive time. Nearly four years of darkness.

L: Couldn't you get published at all?

Y: I felt as if it had returned to the Mao era, not Deng's age anymore. The feeling was even in the air. As poets, two persons became popular partly due to this situation. Outside the poetry circles was Wang Guozhen 汪国真, inside the circles was Hai Zi. These four years were also the hardest time for Colloquial Poetry, for they swept away anything that looked not so pretty or clean. Colloquial Poetry is more or less associated with these elements that are not so pretty or clean, isn't it?

L: Yes.

Y: So it was swept away. On the Chinese poetry scene, what you could see in the journals was 'wheat field'. Under Hai Zi's influence, all the people wrote about the wheat field, the rural imagery. I was very angry about this poetry, which was why I wrote 'Starve the Poets'. During this time, one channel for me was the overseas journal. When I visited Taiwan, they were surprised that I was published by all the Taiwanese poetry journals in the early 1990s. I submitted to whatever journal I found, later all the journals published my work. Every poetry journal published me once, not only once but repeatedly, just because that period was too difficult to endure. I published my works in Taiwan, overseas, including Chinese newspapers in Singapore.

L: You sent your manuscripts via snail mail?

Y: Yes, by snail mail. I was then watched by an agent, because I often submitted to 
overseas journals, keeping correspondence with people overseas in the politically darkest age. Then, my domestic channel was the unofficial magazine.

L: Did unofficial magazines remain active during that period?

Y: Of course, the unofficial magazines took the greatest risk, but now I find the socalled crisis was not so terrible. For instance, what is our present crisis? Now it's the crisis of an age of information rubbish, namely, you publish a poem then it is drown. You publish a poem on Weibo or Wechat but it is flushed away instantly. The crisis of being buried in rubbish. In that time only a few poems were published but all the people could see them, such as in unofficial magazines. How did they publish an unofficial magazine? An unofficial magazine was so big a target that they didn't dare publish it, so big unofficial magazines gradually died away, such as Them. In the case of Not-not, Zhou Lunyou 周伦佑 was in prison. Zhou was released and relaunched Not-not in 1992. Therefore, they began to publish small poetry papers, namely small papers, a small target. After publishing a small paper, they would post it to the wellknown poets all over the country. So you would find your published poems had been seen by all the established poets. If your stuff stood out, like mine, you would be surprised. Even in that couple of years, I got more and more letters, at least from unofficial magazines, if not official ones. Then one day I went out and discovered all of them had known me. It was such an accumulation of reputation. Obviously, from 1993 onwards, the situation immediately turned better. At least a part of my poetry could appear in official magazines. I continued to publish poetry in unofficial ones. I've never forgotten that I came from minjian.

L: It was then you began to submit to overseas magazines like Yihang 一行 (A line)?

Y: A Line was the first overseas magazine that published my poetry.

L: So you became acquainted with Yan Li 严力 through that magazine.

Y: I got to know other overseas magazines because I saw an appendix in $A$ Line that included a number of magazine addresses, primarily Taiwanese ones, A Line's sister magazines, all overseas, so I started to submit to them one by one.

L: Including Otherland 原乡?

Y: Ah yes, including Otherland. I don't remember if I saw it in A Line or elsewhere. 
Once I saw it I submitted to its address. I never missed out on any address. How poor I was then!

L: After this period, you gradually appeared in official magazines?

Y: Yes, since 1993.

L: There was no Internet then.

Y: No.

L: So throughout the 1990 s you-

Y: Kept submitting.

L: Was this the only channel?

Y: Yes. Except in the darkest time, because I found there was no chance to get published. If you do a thing and its success rate is zero percent, you won't do it anymore.

L: Right.

Y: There was a time when it was indeed zero, the darkest time in my words, then I gave up submitting. But after 1993, I remember it was Nan Mo 南嫫 who told me to try. It should be one day in 1992 - in fact our judgement of China's political situation was all naïve and we didn't know how to judge — when Nan Mo told me, 'I had a poem published in Shi Lin 诗林 (Poetry woods), do you want to have a try?' Then she gave me the address of Poetry Woods, though it didn't publish mine-ah yes, I should be thankful to some great editors. It was Zou Jingzhi 邹静之, now a great screenwriter, who published my poetry in Poetry Periodical. He asked me for poetry, which was a pleasant surprise, for I didn't care submit to Poetry Periodical in my university days, considering it as the most superior journal in China. I hadn't submitted my poetry to it, let alone in the darkest time. It was incredible that Zou came to ask me for poetry. In my mind then it was like being already published. I never thought of the rule of the three-layer approvals 三审制. Fortunately, one poem from the pile I sent him was finally published, which was also great. I can remember it was a love poem, 'Huangni jiezhi' 黄泥戒指 (A brown-mud ring). I was so excited and submitted to it again. Consequently, every time I was not treated fair with others, namely a Pyrrhic victory, only one poem was selected from a large submission. The second time I submitted a pile of poems and they put me in an 
impressive column, along with many who had attended the Youth Poetry Meeting like Hei Dachun 黑大春, all famous poets then in my eyes. They also put me, who hadn't attended the Youth Poetry Meeting, in that group. Each other poet had four to eight poems, only me with two poems, like one discriminated against in the group. However, one of my two poems - later I wrote a poem saying mine were two wolves in a flock of sheep — was 'Starve the Poets'. At last, their poems will be forgotten while my poem will stay in the reader's memory, haha.

L: In the 1990s, before 1999, did you have other channels except for the official one?

Y: Umhh ...

L: Did your editorship at Friends in Letters help you?

Y: The situation has been very good then, in the late 1990s.

L: In which years did you work for Friends in Letters?

Y: In 1997. Its official publication was from 1998 to ...

L: Oh, it's in a later period.

Y: Yes, later.

L: To which year?

Y: It ceased publication in December 2000.

L: Did that magazine publish your poetry?

Y: That magazine had great influence. If you interview Xidu Heshang 西毒何歾 in the future, he perhaps will tell you. Now a batch of poets in the New Poetry Classics have revealed in their bios that they graduated from the 'Friends in Letters University' 文友大学. Through Friends in Letters, I cultivated an echelon of poets, mostly those born post-1975 and post-1980 poets.

L: Did you work part-time as its editor?

Y: Yes, part-time but I did it well later. I first did planning, then became its editor-inchief and edited 'Shiji shidian’ 世纪诗典 (Century Poetry Classics). That magazine, quite influential, had a circulation of 160 thousand at its best, a monthly, 160 thousand. In the magazine industry, we calculate a magazine as such: the circulation multiplied by three is the number of its actual readers, which means nearly 500 thousand readers read our magazine. I recommended seven poems in each issue, the 
way I did in the NPC, along with my comments. As I was then the editor-in-chief of a magazine in such a worldly society, other poetry magazines were willing to publish my works. In fact, in the late 1990s, I had a lot of chances to publish my poetry, also because I had become an established poet, right? So it was then a good situation.

L: Any other activities except 'Century Poetry Classics' in Friends in Letters?

Y: Well, everything I did always add something to Chinese culture. There was a word kuping 酷评, whose appearance was related to me. $K u$ as in canku 残酷 (cruel), ping as in pinglun 评论 (comment).

L: Oh?

Y: It was in Yue Gang xinxi ribao 粤港信息日报 (GD-HK Information Daily), a great newspaper, as the centre of Chinese newspapers is Guangdong. An article in $G D-H K$ Information Daily said there appeared a new literary form, unlike zawen 杂文 (essay) in the past, and they called it kuping, namely critiques of cultural phenomena.

L: Oh, you wrote essays for them.

Y: Yes. I started from writing about phenomena, including the article to appeal for dissolving the WA.

\section{Topic Seven}

\section{The Age of the Internet}

L: And after that period came the Internet?

Y: Yes, later the Internet appeared. It started in 2000 and began with the age of the BBS forum. We mainly gathered in the forum of Shi Jianghu 诗江湖 (Poetry jianghu), a free forum. Poetry Jianghu is the domain for Colloquial Poetry, namely the provocative one, because it was the birthplace of the 'Lower Body' 下半身 group.

$\mathrm{L}:$ Ah yes.

Y: So it was the body-related Colloquial Poetry. Later we found many poets—we didn't know them and they didn't appear on Poetry Jianghu, either-were peeping at us 'under water' 潜水. So we knew many people came to Poetry Jianghu to gawk, for there were a lot of quarrels and debates, and the poems were provocative-it seemed 
they were all idle people. Just now you mentioned the word 'avant-garde'; Poetry Jianghu should be an avant-garde platform. However, in the second decade of the 21 st century, this highest platform became the NPC, which is more normalised and canonised.

$\mathrm{L}$ : When did the age of the forum in your words come to an end?

Y: 2010.

L: Just a whole decade?

Y: Yes, it only had a life of ten years. I forget the name of the website who provided free forums - there was such a place. For instance, if you like cooking, you can register such a forum.

L: Everybody could register?

Y: Yes, everybody could register for free. But one day, there was no longer free lunch. Later, there wasn't even paid lunch — the forum became obsolete, replaced first by Weibo, then by Wechat.

L: You once said you paste your poems online every month, from when?

Y: That was during the lifespan of the forum. In the following year I got access to the Internet and from January 2001, I posted my poems online without stop. Why did I posted my poems online? Because of a polemic, within the minjian group, called 'Shen vs Han Polemic' 沈韩之争, have you heard of it?

L: Yes, I know.

Y: A polemic between Shen Haobo 沈浩波 and Han Dong, and each had his supporters, a split within the minjian group. In retrospect, those who supported Shen were Post-Colloquial, and those on Han's side were the Pre-Colloquial Poets and their followers.

L: Haha.

Y: That means, all the polemics, apparently random and occasional, in fact come from a serious choice in aesthetics and standpoint. That is it.

L: Your major online venue is Poetry Jianghu?

Y: Yes. 
L: Later you moved to Ganlu 赶路 (Hurry on with the journey) for a period?

Y: Yes, Hurry on with the journey, but primarily on Poetry Jianghu, with three or four occasionally visited online forums. Hurry on with the journey was one of them.

L: And then, in around 2010, you started the NPC and Chang'an Poetry Festival?

Y: Yes, in 2010. Chang'an Poetry Festival was first established. In 2010, it seemed Poetry Jianghu was really moving towards its end. It seemed that the death of Poetry Jianghu and the birth of the NPC was joined tightly, like a choice of history. As Poetry Jianghu was going to die, some people said they didn't know where to go in future. As a result, a substitute immediately appeared.

L: Are the NPC and Chang'an Poetry Festival more influential than the online forums? As for the NPC, I knew it was popular at the beginning, how is it like now?

Y: More and more popular, and definitely more influential, and I think the problem of Poetry Jianghu was that the poets didn't feel enough pressure, namely, the place was noisy and eye-catching, but it didn't give enough pressure to other poets. You were avant-garde, but others said they were content with not being avant-garde. There was not enough pressure. However, the difference of NPC is that it's more inclusive; a poet cannot stand aloof from it but to admit the situation: I'm not selected by the NPC because my poetry is not good. He cannot say: You can be avant-garde yourself, but I stand aloof. Thus the NPC has a great pressure on them. Even those selfimportant persons also want to be recommended by the NPC, which, of course, depends on whether his work is good. Therefore, its great influence comes from its steadiness, no longer one that leaps to and fro. Once it has order, it becomes more influential. It is a canon, while Poetry Jianghu looked a bit chaotic.

L: Yes, full of quarrels.

Y: A person could make a show of himself even though his work was bad, as long as he behaved strangely by posting a few erotic pictures. This, however, doesn't work in the NPC. If your poetry is not good, you have to keep quiet. So there is still difference.

L: So we have almost covered all your unofficial channels of transmission?

Y: Yes.

L: From the poetry forum to the NPC. 
Y: Yes.

L: And through the traditional channels in the 1990s.

Y: Yes. Have you noticed that, once the Internet appeared, the unofficial magazines were almost gone. I call it 'press down the gourd but the ladle floats up' 摁下葫芦 浮起瓢. The decline of one thing comes with the prosperity of another.

L: Yes.

Y: Because you need funding to run an unofficial magazine, right? And as a paper medium, its ability of transmission is less than e-media, so unofficial magazines, as a phenomenon, gradually declined.

L: If we divide your career into several phases based on the carriers of your work ...

Y: If so, the first was 'teenager publication'.

L: Haha.

Y: Publication in the journals for teenagers, puberty. Then came a dark age. Then a mixture of both official and unofficial magazines. Then the age of the forum. Then came Weibo-

L: How do you divide it yourself based on the development of your writing career?

Y: I agree with Han Dong that the Chinese poetry scene, like elsewhere in the world, should be divided by the year 2000 . The old era is the period of unfree publication, while the new era is the period of free publication, because in the forum, the blog, Weibo or Wechat, at least I can deliver my work to a second person, right? It makes sense to call it 'free publication'. There is an obvious huge difference: In the time of official magazines, the time without unofficial magazines, what you saw was completely an illusion. For example, you would think the one who published most wrote most.

L: Yes.

Y: I once believed Yu Jian and Han Dong had written a lot, because they had published a lot. Later I found it an illusion, for they hadn't written that much. It was not free publication. Now, if you are really interested in a poet, even if he can't publish a single poem in journals, at least he has a blog.

L: That's right. 
Y: Though the blog is no longer popular, many poets still treat it as an archive to store their works, that is, I put all my works on my blog for my own convenience. It's possible nowadays. So I think this is the watershed that distinguishes the new era from the old one.

L: So later you no longer submitted to those overseas Chinese magazines?

Y: Correct. Because, to be frank, I obviously felt no matter how good your poems were and how frequently they once appeared in Taiwanese magazines-I'm really thankful to a magazine, though I heard it was associated with the Taiwan independence movement. Its name was Li shikan 笠诗刊 (Li poetry), Li as in douli 斗笠. It was the most frequently published one among those magazines, bimonthly, as if it had never lacked funding. Because it was a tongren kanwu 同仁刊物 ${ }^{305}$ that seemed to have more funding than Chuang shiji 创世纪 (The epoch poetry quarterly), some people said it was supported by the Democratic Progressive Party 民主进步党. I'm very thankful to this magazine, whose editor-in-chief was Bai Qiu 白萩, a very good poet, one of the top ten Taiwanese poets. I'm thankful to him for having never rejected my submissions even once, one hundred percent publication rate. I had never thought of being so warmly received in Taiwan, as Li Poetry published my poems in almost every issue, more than their peers. I have never met this old guy in person. I thought how come there was such a fair-minded man in the world. I was also curious how come the Taiwanese could accept such provocative work, as they themselves didn't write in this style. Later I met some Taiwanese poets like Hong Hong 鸿鸿 and found that I, then a young poet, had influenced those poets older than me. My poetry, then original and provocative, influenced theirs. But I still had a feeling that they appreciated me the way they appreciated a foreign poet-I couldn't find a sense of belonging. You know many Taiwanese regard themselves as Taiwanese only, unlike the older generation such as $\mathrm{Luo} \mathrm{Fu}$ 洛夫 who

\footnotetext{
305 Tongren kanwu 同仁刊物 or 同人刊物 refers to a magazine edited and run by an independent group of members with similar aesthetics or goals; each member is called its tongren 同仁. Sometimes it only publishes the works of its members. Tongren kanwu stands in contrast to Jiguan kanwu 机关刊物, which usually reflects the ideology of a party or the nation. Their relationship is parallel to that of unofficial and official magazines. Most unofficial magazines in China are tongren kanwu.
} 
still has a concept of China. Those born in Taiwan simply see themselves as Taiwanese. Bai Qiu published a lot of my poems - of course he has never sent me any letters, let alone saying he was interested in me. He just published whatever I sent him. Therefore, I felt, rather than disappointed, I recognized where I belonged. Even if you are under reproof every day in the mainland, those who reproach you still treat you as one of their own, a person on this land. In Taiwan, even though they think you are very good, they still feel you come from another Chinese-speaking country, I think so. They treat you as one from another Chinese-speaking country.

L: When did you stop submitting to the overseas magazines?

Y: In the mid-1990s, about 1995. My last publication in Taiwan was 1994 or 1995. On this side the situation was getting better and better, I gradually became-I also had a sense of danger, feeling I was at risk.

$\mathrm{L}$ : Was there a postal link then?

Y: Yes, there was.

L: You could post a mail to Taiwan?

Y: Yes, I could. Not sure if it was delivered via Hong Kong, but I could post a mail and they could receive it.

\section{Topic Eight}

\section{Translations and Translators}

L: My next question is about the translation of your poetry overseas. Is Denis Mair the first translator of your work?

Y: Yes, he is the first.

L: How did you know him?

Y: He read my work in A Line. He was a tongren of $A$ Line; Allen Ginsberg was also its tongren then.

L: Oh, haha.

Y: He read my work in A Line and was impressed. Recently, at Qinghai Lake 
International Poetry Festival 青海湖国际诗歌节, he told me a story about himself receiving my poetry collection-I have written it in a poem. Published in 1994, my first collection changed my fate. If my publication in Poetry Periodical made me famous overnight, the collection made me a complete celebrity. That collection of mine was a bit unusual, as it was originally a self-publication. One of my classmates was a publisher. It was in the 1990s and every author had to pay 3000 yuan. My God! I only had about 1800, oh no, I had 1200 and borrowed 1800 from others. The 1800 took me two or three years to pay off, haha! So you can see the standard of living in those years. Everybody paid 3000 yuan. Strangely, my self-published book, supposed to be distributed by the author itself, was released and distributed like an officially published one in every bookshop. At that time poetry books sold well; my collection had a print run of 3000 copies and was sold out. Many people bought my book in bookshops, which was equivalent to being officially published. In retrospect, I was lucky. When my publisher tried to get an ISBN from Beijing Normal University Press, the president of BNU, Xu Jialu 许嘉璐, later the vice-chairman of the Standing Committee of the National People's Congress - not sure why my manuscript was subjected to the president's approval, perhaps due to the 4 June Massacre? It needed to be approved not only by the editor-in-chief but by the president of BNU. Xu wrote a comment on the paper about my manuscript: The universities of our socialist country don't nurture such a poet.

L: Haha.

Y: Finally they didn't give me the ISBN, even if I wanted to pay for it. Later my classmate, whose name was Huang Zumin 黄祖民, got a better ISBN from Overseas Chinese Publishing House 中国华侨出版社. Its censorship was so weak-I'm grateful to the publisher for their carelessness or something - that only three of my poems were deleted. In 1995, after my poetry collection came out, the dark age passed and everything was reviving. In October 1995, there was a symposium on contemporary poetry at Peking University. At the symposium, Xie Mian 谢冕 said with emotion, 'This is the first time after 1989'. After 1989, there was no such symposium until October 1995. Later, all their speeches were published in the literary 
magazine Zuojia 作家 (Writers). At such a symposium on the Chinese poetry scene 1990-1994, four people mentioned my poetry: Xie Mian, Wu Sijing, Yang Kuanghan 杨匡汉 and perhaps Lin Mang 林莽. ${ }^{306}$ In a group of only a dozen people in total, four mentioned me. The publication of their speeches in Writer Magazine made me an established poet. It seemed as if I was the number one among the new poets in the 1990s. So the situation was changed by my collection. Denis Mair told me that he was then employed as a translator by a Taiwanese temple where he stayed for three months but felt extremely lonely. Yan Li posted him a copy of my poetry collection from New York to the temple in Taiwan. Denis Mair said he read my collection overnight and went downhill at daybreak, because he suddenly felt the secular world was so beautiful, haha.

L: Haha.

Y: He said that he saw in my poetry the kaleidoscopic world is so wonderful. From then on, he started to translate my poetry. However, his translation is also 'ineffective'not 'ineffective' in its normal sense, not the quality. Everybody said Mair's translations were good. Judging from the responses to my poetry reading, they were very good. My poems in Swedish, translated from his English versions, brought great laughter to the audience. One of the poets laughed until her tears came out and she wiped them off with a handkerchief. This was evidence that his translations are good. But he didn't have the habit of submitting and seldom accumulated the resources of publication. He seldom published his translations unless the editors reached out to him, thus the publication of his translation became a rare thing.

L: That's true.

Y: Denis Mair was the first translator. Ouyang Yu was the second.

L: Their translations were published in Hong Kong as a collection?

Y: Yes. That's my self-publication but it was strict then. That publishing house, the Milky Way Publishing 银河出版社, belongs to Fu Tianhong 傅天虹, who was quite selective. I asked them each to contribute half of the translations and had the

306 These four figures are among the most influential critics and poets of the 1990s. 
book published. They both liked it. Ouyang Yu has asked me for the book a few times, one copy a time, several times in total.

L: Did Ouyang Yu publish a lot of his translations?

Y: Yes. He published a lot. Ouyang and I had a few 'honey-years' 蜜年, haha.

L: From which year?

Y: At first, I published my poetry in his Otherland for once. He also published my novella in Otherland. Then he began to translate my poetry. It was when I worked for Friends in Letters. The period lasted for three years, from 1997 to 2000. In 2000, he came to the mainland and his interest changed. My guess.

L: He never published them as a collection until the one with Yang Xie 杨邪 and Shu Cai 树才 came out in 2013?

Y: Yes. But that opportunity was earned by me. The publisher saw my poetry and decided to publish the book. They two got a lift, haha.

L: Was it in that period that Gig Ryan refused to publish your poetry?

Y: Yes, towards the end of that period.

L: Who was your next major translator?

Y: Some translated one or two poems. I can't remember. There was a quiet period after them two.

L: When did Simon Patton appear?

Y: I'm going to say about this. After Mair and Ouyang there was a quiet period when it seemed no one was translating me. Mair's translation was always 'ineffective', haha. His translations can definitely be published as more than one collection. If he publishes a collection, it must be a thick one, as he has translated not only my short poems but my long ones. He once gave me a bag of very thick manuscripts. As for other languages, there was a story of a windfall. In the age of the Internet-my luck all came from the Internet - an Israeli translator tried very hard to find me. His first letter to me said, 'I've been looking for you for a few years.' Haha. Because he occasionally read my poems somewhere. He was very interested and wanted to translate them. He had been looking for me for two or three years. When he found me, he had finished a collection of translations. So when he found me, he just needed 
me to give permission. After a few months, that book was suddenly released, a collection in Hebrew translation published in Israel in 2006. From the angle of vanity, I was extremely glad, as we all knew Hebrews were very clever. Later Yan Li said, 'It's worth celebrating to be noticed by that nation!'

L: Haha.

Y: Moreover, this translator is a DJ of Israeli National Radio. After he translated my poetry, he read it every day on the radio. You can guess how many people have heard it.

L: That sounds good.

Y: This was in 2006. At almost the same time, Simon Patton appeared.

L: Did Patton appear in 2008?

Y: Yes, Patton had put it online by then. I went to Rotterdam in 2007 and Aldeburgh in 2008. When I went to Aldeburgh-

L: Was it your first time to go abroad?

Y: No, I visited Sweden in 2002.

L: For what reason?

Y: The 2002 visit had something to do with Yu Jian. A female Sweden poet founded an art exhibition centre in Kunming, like 798 Art Zone, with a café, which became an event venue. Naturally she got to know Yu, who arranged some activities of cultural exchange, including a dancer and three poets. Yu recommended five poets, including himself, as they knew he was a famous Chinese poet. Then they selected two poets out of five, including me.

L: So you later went to Rotterdam. And to the UK with Patton?

Y: Yes.

L: In which year did you go to Macedonia?

Y: To Macedonia in 2011. After Simon Patton, here comes Martin Winter. He can translate into both German and English. It seems my collection in German translation will come out, a very thick book, bilingual. In fact, he translates more into English than into German and he has enough English translations to publish a collection. He has translated for a few years. Of course, I introduced the NPC to him and let him 
select from a wider range.

L: Is he still translating now?

Y: Yes. Of course, I still have a little doubt that someone said his English is not so good as his German. English is not his mother tongue but his English is good enough, as his wife is American and they have been married for over twenty years, a complete English-speaking family. His two children were born in Beijing and raised in Taipei. His family has lived in China for thirteen years, nine years in Beijing. Why nine years? Because his wife worked as a translator at Austrian Embassy for nine years. Their two children, both born in Beijing, grew up in a trilingual environment-Beijing dialect, German and English. Therefore, his English is also good, though not so good as his German. There is evidence that his German is good. In terms of fiction translation, he is the translator of Liu Zhenyun's 刘震云 Wengu yijiusi'er 温故一 九四二 Remembering 1942. Winter has another iconic work. When Liu Xiaobo zhuan 刘晓波传 (Biography of Liu Xiaobo) was going to be published in Germany, the German press needed a translator to finish it within a month ...

$\mathrm{L}: \mathrm{Oh}$, he is the translator.

Y: Yes. They found him, who finished it in merely twenty days.

L: So the collection to be published overseas ...

Y: As I remember, Chinese Literature Today once published some translations by Heather Inwood.

L: Ah yes.

Y: Then she is a translator, too.

L: But she only translated several poems?

Y: Ten.

L: So these are almost all the translators of your poetry?

Y: Yes.

L: But there is only one full collection in English?

Y: Yes. In English there are one collection and a half, haha, the collection of three poets by Ouyang, and one self-published.

L: And one published in Israel. 
Y: Yes, in modern Hebrew.

L: And a German collection is forthcoming.

Y: Yes. There is also a pamphlet at Rotterdam Poetry Festival but that doesn't count.

L: Without an ISBN?

Y: No, it didn't have one, so it should be counted out.

L: And you have attended international poetry festivals four or five times in total?

Y: Yes, I've attended nearly all the big ones. The biggest is Struga in Macedonia, with a long history. The second is Rotterdam. I haven't attended the third biggest one, Medellín in Columbia - it seems they directly send their official invitations to poets. The British one is also good, with a longest history in the UK. As we know, the UK is a prominent country of poetry.

L: You also translated foreign poets, the American one ...

Y: Charles Bukowski, haha.

L: Haha, since 1995?

Y: Since 1995.

L: And you have been translating him on and off?

Y: Yes. In fact, we only translated 23 poems in 1995, then my wife gave birth to my son and our translation stopped. There are three phases: the second phase is 2011, and in 2013 or 14 , it should be 2013

L: Have you published them before?

Y: Yes, I attach much importance to publication and, actually, I have been publishing them ceaselessly. The influence of Bukowski in China should be attributed to me.

L: Then he also has the greatest influence over your writing?

Y: Yes. I think he is the type of writer who walks along with you in your progress rather than an established master. You translate a bit of him, which urges you to go a step forward. Then you translate a bit again and step forward again. He walks shoulder to shoulder with you.

L: What about Allen Ginsberg? Who gave you the nickname of 'China's Ginsberg'?

Y: In fact, since the appearance of Bukowski, I've had a growing dislike of Ginsberg. First, I dislike his long sentences, as you can see I seldom write long sentences. I still 
feel he is closer to my youth, farther and farther from my later self, because his poetry is still a manifesto, right? A great manifesto to the world, unlike Bukowski who writes as the way he lives, his poetry is his very being. I think Bukowski is on a higher level, while Ginsberg still tries to challenge the world, right?

L: Yes.

Y: Thus I think, in my puberty, I had no problem with Ginsberg, who was my first icon. However, later he became estranged from me and suddenly turned into one unrelated to me. First, I dislike long sentences; second, I dislike parallelism. Both are his characteristics. Third, I dislike sentences with heavy lyricism, and he is quite lyrical.

L: That's true. He is the greatest follower of Walt Whitman.

Y: Yes. He said he had learned from Whitman and William Blake: Blake's mysticism and Whitman's poetic style.

L: But who gave you such a nickname.

Y: Liu Yaozhong 刘耀中, an Chinese American, do you know him?

L: No.

Y: He is based in Los Angeles, an important person to me. He seemed to have some technological background, an old playboy, who is more fashionable-minded than $\mathrm{Mu}$ Xin 木心. Mu Xin is still a little pretentious while Liu must be quite untrammeled. His hobby is to write essays about American philosophers, writers and poets and publish them in Los Angeles-based Chinse newspapers and elsewhere. Later he had a collection of essays published by the Oriental Press 东方出版社 in China. Like Denis Mair, he read my poems in A Line. I was a correspondent of $A$ Line in Xi'an, which was why the police watched me. There was my address in the magazine.

L: Is A Line still alive?

Y: Already defunct. Liu found my address and sent a letter to me. Why didn't I find him pretentious? Why was I willing to accept this nickname? Because in the first letter he wrote me, the first line is: Dear Mr. Yi Sha, China's Ginsberg, haha. Below the letter is: Respect to China's Ginsberg! He posted me a photocopy of Luosanji ribao 洛杉矶日报 (LA daily), including his essay on Allen Ginsberg.

L: When did this happen? 
Y: In the darkest time, in 1991 or 1992. He was so perceptive that all his judgements turned out to be right. He said, 'There's another poet more like you.' You can see how accurate his judgement was, a prediction that I would turn from Ginsberg to Bukowski. Later he sent me his essay on Bukowski. So my first glimpse at Bukowski was his rough translations in his essay. I found the experiences of this poet were legendary, haha, 'a drunken poet'.

L: Bukowski was still alive then.

Y: At that time, yes, still alive.

L: He died in 1994 ?

Y: Yes. When Liu send me a collection of Bukowski for the first time, Bukowski died. That was in 1994, the year he died. When I got the book he had already passed away. Yes, Bukowski died in 1994, and Ginsberg died in 1997.

L: I've seen your translations. I think the best were Bukowski and Rabindranath Tagore, especially the latter.

Y: Ah yes, thank you.

L: Well, that's all for our interview. Many thanks for taking the time to chat!

Y: Excellent. Thanks. 


\section{Bibliography}

Akhmatova, Anna 安娜 • 阿赫玛托娃. Wo zhidao zenyang qu ai: Ahematuowa shixuan 我知道怎样去爱：阿赫玛托娃诗选 (I know how to love: selected poems of Anna Akhmatova), trans. Yi Sha 伊沙 and Lao G 老 G. Beijing: Waiwen chubanshe, 2013.

. Wo zhidao zenyang qu ai: Ahematuowa shige jingxuan ji 我知道怎样去爱:

阿赫玛托娃诗歌精选集 (I know how to love: best poems of Anna Akhmatova), trans. Yi Sha 伊沙 and Lao G 老 G. Hangzhou: Zhejiang wenyi chubanshe, 2018. Allen, Joseph R. In the Voice of Others: Chinese Music Bureau Poetry. Ann Arbor: Center for Chinese Studies, The University of Michigan, 1992.

Anderson, Marston. The Limits of Realism: Chinese Fiction in the Revolutionary Period. Berkeley, CA: University of California Press, 1990.

Bukowski, Charles. Play the Piano Drunk Like a Percussion Instrument Until the Fingers Begin to Bleed a Bit. Santa Rosa, CA: Black Sparrow Press, 1979. . You Get So Alone at Times That It Just Makes Sense. Santa Rosa, CA: Black Sparrow Press, 1986.

查尔斯 - 布考斯基. Bei kaojiutong: Bukaosiji shixuan 背靠酒桶: 布考斯基 诗选 (Leaning on wood: selected poems of Charles Bukowski), trans. Yi Sha 伊 沙 and Lao G 老 G. Unofficial publication, 2011.

. Ganjing laotou: Bukaosiji shixuan 干净老头: 布考斯基诗选 (A clean old man: selected poems of Charles Bukowski), trans. Yi Sha 伊沙 and Lao G 老 G. Unofficial publication, 2012.

. Jipin: Bukaosiji shixuan 极品: 布考斯基诗选 (The finest of the breed: selected poems of Charles Bukowski), trans. Yi Sha 伊沙 and Lao G 老 G. Unofficial publication, 2012.

Cai, Zong-qi, ed. How to Read Chinese Poetry: A Guided Anthology. New York: Columbia University Press, 2007. 
Cao Minglun 曹明伦. 'Fuluosite shige zai Zhongguo de yijie—jinian fuluosite shishi 50 zhounian’ 弗罗斯特诗歌在中国的译介——纪念弗罗斯特逝世 50 周年 (Introduction and translation of Robert Frost in China: commemorating Robert Frost's 50th death anniversary). Zhongguo fanyi 中国翻译 (Chinese translators journal), No. 1, 2013, pp. 70-75.

'Chang'an shige jie zhengfa xing: shi zai xin shiji' 长安诗歌节政法行：诗在新世纪 (Chang'an Poetry Festival at Northwest University of Politics and Law: poetry in the new century), https://kknews.cc/zh-sg/culture/pokrv2.html, accessed 21 September 2019.

Chang, Kang-I Sun and Stephen Owen, eds. The Cambridge History of Chinese Literature, Vol. 1 \& 2. Cambridge: Cambridge University Press, 2010.

Cheah, Pheng. What Is a World?: On Postcolonial Literature as World Literature. Durham: Duke University Press, 2016.

Chen, Jing. 'Refashioning Print Literature: Internet Literature in China'. Comparative Literature Studies, Vol. 49, No. 4, Special Issue: Modern China and the World: Literary Constructions, 2012, pp. 537-46.

Chen Pingyuan. The Development of Chinese Martial Arts Fiction: A History of Wuxia Literature, trans. Victor Petersen. Cambridge: Cambridge University Press, 2016.

Chen, Shaoli 陈韶利. 'Shi li shi wai de maodun duili: xidu Yi Sha mingzuo "Esi shiren” "诗里诗外的矛盾对立一一细读伊沙名作《饿死诗人》 (Antitheses inside and outside poetry: reading Yi Sha's 'Starve the poets'). Mingzuo xinshang 名作欣赏 (Masterpieces review), No. 1, 2006, pp. 61-64.

Chen Sihe 陈思和. 'Minjian de fuchen’ 民间的浮沉 (The ups and downs of minjian). Shanghai wenxue 上海文学 (Shanghai literature), no. 1, 1994, pp. 68-80. . 'Minjian de huanyuan'民间的还原 (The restoration of minjian). Wenyi zhengming 文艺争鸣 (Literature and art forum), no. 1, 1994, pp. 53-61.

Chen Yinke 陈寅恪. Yuan Bai shijian zhenggao 元白诗笺证稿 (An annotated edition of the poems by Yuan Zhen and Bai Juyi). Beijing: Shenghuo dushu xinzhi sanlian shudian, 2001.

Chen Yongchao 陈泳超. 'Zuowei xueshu shi duixiang de “minjian wenxue”, 作为学 术史对象的“民间文学” (Minjian wenxue as a subject of academic research). 
Minzu wenxue yanjiu 民族文学研究 (Studies of ethnic literature), No. 1, 2004, pp. 5-14.

Chen Zhongyi 陈仲义. 'Gujin shixin, heyi huwen jiaohui? — ping Yi Sha Tang nengfou chengwei mingpian’ 古今诗心, 何以互文交汇? -—评伊沙《唐》能否成为 名篇 (Poetry hearts ancient and modern, how do they realise intertextuality? —on whether Yi Sha's Tang can become a masterpiece). Mingzuo xinshang 名作欣赏 (Masterpieces review), No. 9, 2005, pp. 105-11.

. 'Siliang zenneng bo qianjin: du Yi Sha “Huanghe”, 四两怎能拨千斤一一读 伊沙 “黄河” (How does four liang move a thousand jin: reading Yi Sha's ‘Yellow River'). Mingzuo xinshang 名作欣赏 (Masterpieces review), No. 21, 2008, pp. 63-65.

. 'Yi Sha shige lun: “shaduba” bosa ji “huwenxing” huishou’ 伊沙诗歌论: “杀 毒霸” 播撒及 “互文性” 回收 (On Yi Sha's poetry: its 'viral' spread and ‘intertextual' retrieve). Wenyi zhengming 文艺争鸣 (Literature and art forum), no. 10,2009 , pp. 136-41. . 'Fei yixianghua de “shishi shiyi”" 非意象化的 “事实诗意” ('Poetry of facts' without images). Hongyan 红岩 (Red cliff), No. S2, 2011, pp. 23-28. . 'Xinshiji wunian wangluo shixiang guancha' 新世纪 5 年网络诗象观察 (Observations on internet poetry phenomena during the five years of the new century), 2006, http://www.poemlife.com/libshow-1596.htm, accessed 16 September 2017.

Cheng Guangwei 程光伟. 'Jiushi niandai shige: ling yi yiyi de mingming' 九十年代 诗歌: 另一意义的命名 (Poetry in the nineties: naming in another sense). Shanhua 山花 (Mountain flowers), No. 3, 1997, pp. 70-74. , ed. Suiyue de yizhao: jiushi niandai wenxue shuxi, shige juan 岁月的遗照: 九十年代文学书系, 诗歌卷 (A portrait of years gong by: literature of the nineties, poetry volume). Beijing: Shehui kexue wenxian chubanshe, 1998. 'Chongyi Taige'er shiji yin zhengyi: shiren Yi Sha dongle shui de “chulian”?' 重译泰 戈尔诗集引争议：诗人伊沙动了谁的 “初恋” ? (Dispute caused by retranslating Tagore: whose first love has poet Yi Sha touched?). Dushi shibao 都市时报 (Capital times), 
http://blog.sina.com.cn/s/blog_489db0970102eaph.html, accessed 20 May, 2019.

Chow, Rey. Writing Diaspora: Tactics of Intervention in Contemporary Cultural Studies. Bloomington: Indiana University Press, 1993.

Cixous, Hélène, Keith Cohen and Paula Cohen. 'The Laugh of the Medusa'. Signs, Vol. 1, No. 4, Summer 1976, pp. 875-93.

Crespi, John A. 'Poetic Memory: Recalling the Cultural Revolution in the Poems of Yu Jian and Sun Wenbo.' In Christopher Lupke ed., New Perspectives on Contemporary Chinese Poetry. New York: Palgrave Macmillan, 2007, pp. 165183.

Damrosch, David. What Is World Literature? Princeton: Princeton University Press, 2003.

Day, Michael. China's Second World of Poetry: The Sichuan Avant-garde, 1982-1992. Leiden: Digital Archive for Chinese Studies (DACHS). Leiden University, 2005. . 'Online Avant-Garde Poetry in China Today'. In Christopher Lupke, ed. New Perspectives on Contemporary Chinese Poetry. New York: Palgrave MacMillan, 2008, pp. 201-17.

Debritto, Abel. Charles Bukowski, King of the Underground: From Obscurity to Literary Icon. New York: Palgrave Macmillan, 2013.

Deng Gen 邓艮. 'Yipi culi, zhengliang de shazi: ye tan Yi Sha shige de richang yu kouyu' 一匹粗粝、铮亮的砂子——也谈伊沙诗歌的日常与口语 (A coarse, shiny sand: everyday and colloquial elements in Yi Sha's poetry). Shanhua 山花 (Mountain flowers), No. 16, 2012, pp. 101-03.

Dong Yingchun 董迎春. 'Lun 20 shiji 90 niandai shige wenxue yu wenhua de guanxi' 论 20 世纪 90 年代诗歌文学与文化的关系 (The relationship between poetry and culture in the 1990s). Gaoxiao sheke dongtai 高校社科动态 (Social sciences perspectives in higher education), No. 4, 2015, pp. 26-34.

Eagleton, Terry. Literary Theory: An Introduction. Carlton: Blackwell Publishing, 2008. Edmond, Jacob. A Common Strangeness: Contemporary Poetry, Cross-Cultural Encounter, Comparative Literature. New York: Fordham University Press, 2012. . Make It the Same: Poetry in the Age of Global Media. New York: Columbia University Press, 2019. 
Egan, Charles H. 'Were Yüeh-fu Ever Folk Songs? Reconsidering the Relevance of Oral Theory and Balladry Analogies'. Chinese Literature: Essays, Articles, Reviews (CLEAR), Vol. 22, pp. 31-66.

Feng, Jin. Romancing the Internet: Producing and Consuming Chinese Web Romance.

Leiden: Brill, 2014.

'Folk literature' entry. Encyclopaedia Britannica. https://www.britannica.com/art/folkliterature, accessed 4 July 2016.

Frankel, Hans. 'Yüeh-fu Poetry'. Studies in Chinese Literary Genres. Ed. Cyril Birch. Berkeley: University of California Press, 1977, pp. 69-107.

Fu Hao 傅浩. 'Zheng Zhenduo yi Feiniao ji zhixia' 郑振铎译《飞鸟集》指瑕 (Mistakes in Zheng Zhenduo's translation of Stray Birds). Dongfang fanyi 东方 翻译 (Oriental translation), No. 2, 2018, pp. 60-62.

Han Dong 韩东. 'Youguan Dayanta' 有关大雁塔 (Concerning the Wild Goose Pagoda). Zhonghua shiku: Han Dong shixuan 中华诗库: 韩东诗选 (Collections of Chinese poetry: Han Dong), http://www.shigeku.org/shiku/xs/handong.htm\#14, accessed 17 May 2017. . 'Zizhuan yu shijian’ 自传与诗见 (Autobiography and poetic views). Shige bao 诗歌报 (Poetry news), 6 July 1988, p. 3.

Han Fanghang 韩方航. 'Shiren shagnwang, 17 nian qian “qitian qiye” lunzhan beihou, shi zenyang yige jianghu’ 诗人上网, 17 年前 “七天七夜” 论战背后, 是怎 样一个江湖? (Poets going online: what a jianghu lay behind the 'seven-day, seven-night' polemic 17 years ago), 18 September 2017. https://www.qdaily.com/articles/45263.html, accessed 12 September 2019.

Hockx, Michel. 'Virtual Chinese Literature: A Comparative Case Study of Online Poetry Communities.' The China Quarterly, No. 183, Culture in the Contemporary PRC, September, 2005, pp. 670-91.

. Internet Literature in China. New York: Columbia University Press, 2015.

Hou Danqing 侯丹青. 'Yingguo shiren Feilipu Lajin de yijie yanjiu jiqi zhenwang' 英国诗人菲利普·拉金的译介研究及其展望 (A study and prospect of British poet Philip Larkin in Chinese translation). Changcheng 长城 (The Great Wall), No. 8, 2011, pp. 199-200.

$\mathrm{Hu}$ Shi 胡适. Baihua wenxue shi 白话文学史 (A history of vernacular literature). 
Tianjin: Baihua wenyi chubanshe, 2002.

Hughes, Geoffrey. Political Correctness: A History of Semantics and Culture. Malden, MA: Wiley-Blackwell, 2010.

Hung, Chang-tai. Going to the People: Chinese Intellectuals and Folk Literature, 19181937. Cambridge: Harvard University Asia Centre, 1985.

Inwood, Heather. 'Yi Sha: Running His Race in the "Ninth Lane".' Chinese Literature Today, Vol. 2, No. 2, pp. 6-10.

. 'Poetry for the People? Modern Chinese Poetry in the Age of the Internet.' Chinese Literature Today, Vol. 5, No. 1, pp. 44-54.

- Verse Going Viral: China's New Media Scenes. Seattle: University of Washington Press, 2014.

Iyer, Pico. 'Celebrities Who Travel Well'. TIME, 16 June 1986. http://content.time.com/time/subscriber/article/0,33009,961603-1,00.html, accessed 9 October 2019.

Jiang Fei 姜飞. 'Lishi de meili yu shiren de chunxin’ 历史的美丽与诗人的春心 (The beauty of history and the amorous heart of the poet), Hongyan 红岩 (Red cliff), No. S1, pp. 32-36.

Li Bai 李白. Li Taibai quanji 李太白全集 (The complete poems of Li Bai). Beijing: Zhonghua shuju, 1977.

Li, Dian. 'Naming and Antinaming: Poetic Debate in Contemporary China.' In Christopher Lupke ed., New Perspectives on Contemporary Chinese Poetry. NY: Palgrave Macmillan, 2007, pp. 185-200.

Li, Hsiao-t'i. 'Making a Name and a Culture for the Masses in Modern China'. Positions: East Asian Cultures Critique, Vol. 9, No. 1, 2001, pp. 29-60.

Li Xiaoling 李小玲. 'Fan ben su yuan: dui Zhongguo minjian wenxue gainian ji lilun de fansi’ 反本溯源：对中国民间文学概念及理论的反思 (Tracing the source: reflections on the concept and theory of Chinese folk literature). Tansuo yu zhengming 探索与争鸣 (Exploration and free views), No. 10, 2017, pp. 155-64.

Li Zhimin 黎志敏. 'Zhongguo xinshi Zhong de shisihangshi' 中国新诗中的十四行 诗 (The sonnet in Chinese new poetry). Waiguo wenxue yanjiu 外国文学研究 (Foreign literature studies), No. 1, 2000, pp. 65-68. 
Liang Yujing, ed. and trans. Zero Distance: New Poetry from China. Honolulu, HI: Tinfish Press, 2017.

Liang Yujing 梁余晶 and Ouyang Yu 欧阳昱. “Guanyu fanxueyuan, “fennu” yu shuangyu一Ouyang Yu fangtan” 关于反学院、“愤怒”与双语一一欧阳昱访 谈 (Regarding anti-academy, 'anger' and bilingualism: an interview with Ouyang Yu). Huawen wenxue 华文文学 (Literature in Chinese), No.2, 2012,pp. 28-33.

Lin, Julia C. Modern Chinese Poetry: An Introduction. Seattle, WA: University of Washington Press, 1972.

Liu Lizhi 刘立志. 'Shijing guofeng minge wenti yanjiu de huigu yu jiantao'《诗经 • 国 风》民歌问题研究的回顾与检讨 (Retrospective investigation on the folk song issue in The Book of Songs). Nanjing shifan daxue wenxueyuan xuebao 南京师 范大学文学院学报 (Journal of School of Chinese Language and Culture, Nanjing Normal University), No. 4, 2010, pp. 38-43.

Lu, Hongwei. 'Body-Writing: Shanghai Baby's Love Affair with Transnational Capitalism.' Chinese Literature Today, Summer 2010, pp. 41-46.

'Lu Xun wenxue jiang pingjiang chouwen buduan dianwu Lu Xun' 鲁迅文学奖评奖 丑闻不断玷污鲁迅 (Scandals about the Lu Xun Literary Prize continues to defile Lu Xun), http://star.news.sohu.com/20150707/n416284173.shtml, accessed 9 October 2017.

Luo Genze 罗根泽. Yuefu wenxue shi 乐府文学史 (A history of yuefu poetry). Beijing: Wenhua xueshe, 1932.

Luo Zhenya 罗振亚. “"Hou xiandai” lushang de gujue tanxian: 1990 niandai Yi Sha shige lun” “后现代”路上的孤绝探险—1990 年代伊沙诗歌论（A lonely exploration on the 'postmodern' road: Yi Sha's poems in the 1990s). Guangdong shehui kexue 广东社会科学 (Guangdong social sciences), No. 4, 2013, pp. 16472.

. 'Jiushi niandai xianfeng shige de “xushi shixue” 九十年代先锋诗歌的 “叙 事诗学” ('Narrative poetics' of the avant-garde poetry in the 1990s). Wenxue pinglun 文学评论 (Literary review), No. 2, 2003, pp. 88-93. 
Mair, Victor H. and Mark Bender, eds. The Columbia Anthology of Chinese Folk and Popular Literature. New York: Columbia University Press, 2011.

McDougall, Bonnie S. 'Dissent Literature: Official and Nonofficial Literature In and About China in the Seventies.' Contemporary China, III, No. 4, 1979, pp. 49-79. . 'The Anxiety of Out-fluence: Creativity, History and Postmodernity'. In Wendy Larson and Anne Wedell-Wedellsborg, eds., Inside Out: Modernism and Postmodernism in Chinese Literary Culture. Aarhus: Aarhus University Press, 1993, pp. 99-112.

. Translation Zone in Modern China: Authoritarian Command Versus Gift Exchange. Amherst, MA: Cambria Press, 2011.

McDougall, Bonnie S. and Kam Louie. The Literature of China in the Twentieth Century. Gosford: Bushbooks, 1998.

'Mianyang jiangjin baiwan she Li Bai Shige Jiang, liang nian yi jie' 绵阳奖金百万设 李白诗歌奖, 两年一届 (Mianyang establishes Li Bai Poetry Award with onemillion-yuan award money, accorded every other year), posted on 24 December 2014, https://kknews.cc/other/r9a3lj4.html, accessed 28 September 2019.

Mozi 墨子. Mozi 墨子 (Mozi), trans. W. P. Mei, https://ctext.org/mozi/anti-fatalismi, accessed 3 December 2019.

Ouyang Yu 欧阳昱. 'Dapo xintian: dangdai Zhongguo shige de yingyi’ 打破新天: 当代中国诗歌的英译 (Breaking new sky: English translation of contemporary Chinese poetry). Huawen wenxue 华文文学 (Literature in Chinese), No. 3, 2013, pp. 24-36.

. 'Gaobie Hanyu: ershiyi shiji xin huaren de chulu?' 告别汉语: 二十一世纪 新华人的出路? (A farewell to the Chinese language: A way out for the new Chinese in the twenty-first century?), http://www.xys.org/xys/netters/psi4/ouyang.txt, accessed 16 October 2017. . 'Shuangyu rensheng' 双语人生 (Living a bilingual life). Huawen wenxue 华 文文学 (Literature in Chinese), No. 5, 2014, pp. 33-37. , ed and trans. In Your Face: Contemporary Chinese Poetry in English Translation. Otherland 8. 2002. 
. 'Lower Downs, Rubbish and Low Poetry.' Otherland 194, Autumn 2009, p. 43.

http://overland.org.au/?page id=931, accessed 23 October 2019.

Owen, Stephen. 'The Anxiety of Global Influence: What Is World Poetry?' The New Republic, 19 November 1990, pp. 28-32.

. The Making of Early Chinese Classical Poetry. Cambridge: Harvard University Asia Center, 2006.

, ed. and trans. The Poetry of Du Fu. Boston, MA: De Gruyter, 2015.

Pound, Ezra. 'A Few Don'ts'. Poetry Foundation's website:

https://www.poetryfoundation.org/articles/69409/a-retrospect-and-a-few-donts, accessed 3 August 2020.

. 'A Retrospect'. Poetry Foundation's website:

https://www.poetryfoundation.org/articles/69409/a-retrospect-and-a-few-donts, accessed 3 August 2020.

. 'In a Station of the Metro'. Poetry Foundation's website:

https://www.poetryfoundation.org/poetrymagazine/poems/12675/in-a-station-

of-the-metro, accessed 3 August 2020.

Qin Bazi 秦巴子 and Yi Sha 伊沙. Zai Chang'an 在长安 (In Chang'an). Hong Kong: Yinhe chubanshe, 2012.

Ran Xiaoping 再小平. 'Cong shuxie shenti dao shenti shuxie’ 从书写身体到身体书

写 (From writing about the body to body writing). Beijing daxue xuebao 北京 大学学报 (Journal of Peking University), Issue S1, 2003, pp. 128-33.

Raskin, Jonah. American Scream: Allen Ginsberg's Howl and the Making of the Beat Generation. Oakland, CA: University of California Press, 2004.

Roberts, Margaret E. Censored: Distraction and Diversion Inside China's Great Firewall. Princeton, NJ: Princeton University Press, 2018.

Sang Ke 桑克. 'Hulianwang shidai de Zhongwen shige' 互联网时代的中文诗歌 (Chinese-language poetry in the Internet age), 2001, http://www. poemlife.com/libshow-228.htm, accessed 16 September 2017.

Shakespeare, William 威廉 - 莎士比亚. Shashibiya shisihangshi 莎士比亚十四行诗 (Sonnets of William Shakespeare), trans. Yi Sha 伊沙 and Lao G 老 G. Xining: 
Qinghai renmin chubanshe, 2014.

Shen Haobo 沈浩波. 'Dangdai Zhongguo shige zhong de sizhong xurongxin' 当代中 国诗歌中的四种虚荣心 (Four types of vanities in contemporary Chinese poetry). Shen Haobo 沈浩波. Mingling wo chenmo 命令我沉默 (Command me to be silent). Hangzhou: Zhejiang wenyi chubanshe, 2013, pp. 1-12.

. 'Hualian zhi ye' 花莲之夜 (Night of Hualien). In Yi Sha 伊沙, ed. Xin shiji shidian, diwu ji 新世纪诗典, 第五季 (New century poetry classics, vol. 5), Hangzhou: Zhejiang renmin chubanshe, 2016, p. 175.

. 'Night of Hualien', trans. Liang Yujing. jubilat, No. 31, 2017, p. 112.

. 'Mali de aiqing' 玛丽的爱情 (Mary’s love). In Yi Sha 伊沙, ed. Xin shiji shidian, diyiji 新世纪诗典, 第一季 (New century poetry classics, Vol. I), Hangzhou: Zhejiang wenyi chubanshe, 2012, p. 2.

. 'Na yiduan lishi, wo hai congwei hepan tuochu: zai taopao de rizi li' 那一段历 史, 我还从未和盘托出: 在逃跑的日子里 (On that bit of history, I have never yet laid it all out: my days on the run), http://blog.sina.com.cn/s/blog_4b8f46d40100cu9w.html, 2009, accessed 2 October 2017.

. 'Wo de yingxiong' 我的英雄 (My heroes). In Shen Haobo's weibo: https://www.weibo.com/p/2304185951573c0102x9n8?mod=zwenzhang, accessed 25 May 2019.

. 'Xiabanshen xiezuo ji fandui shangbanshen' 下半身写作及反对上半身 (Lower body writing and anti-upper-body-ism). Shikan 诗刊 (Poetry periodical), No. 8, 2002, pp. 77-80.

. 'Zhongguo shige de canren yu guangrong' 中国诗歌的残忍与光荣 (The cruelty and glory of Chinese poetry), http://www.poemlife.com/libshow2011.htm, accessed 9 October 2017.

‘Shen Haobo, Yi Sha yu Yu Jian de juelie jingguo’ 沈浩波、伊沙与于坚的决裂经过 (Shen Haobo's and Yi Sha's breaks with Yu Jian), http://blog.sina.com.cn/s/blog_a6f2b2ce0101oxiy.html, accessed 15 December 2019. 
Shi Zhi. Winter Sun, trans. Jonathan Stalling. Norman, OK: University of Oklahoma Press, 2012.

Tagore, Rabindranath 拉宾德拉纳特・泰戈尔. Jitanjiali 吉檀迦利 (Gitanjali), trans. Yi Sha 伊沙 and Lao G 老 G. Beijing: Beijing lianhe chuban gongsi, 2017. .Feiniao ji 飞鸟集 (Stray birds), trans. Yi Sha 伊沙 and Lao G 老 G. Beijing: Beijing lianhe chuban gongsi, 2017. . Sheng ru xiahua, si ru qiuye: Taige'er mingshi jingxuan 生如夏花, 死如秋 叶: 泰戈尔名诗精选 (Let life be beautiful like summer flowers and death like autumn leaves: selected poems of Rabindranath Tagore), trans. Yi Sha 伊沙 and Lao G 老 G. Nanjing: Jiangsu wenyi chubanshe, 2013. . Stray Birds. Radford, VA: Wilder Publications, 2009. . Xinyue ji 新月集 (The crescent moon), trans. Yi Sha 伊沙 and Lao G 老 G. Beijing: Beijing lianhe chuban gongsi, 2017.

Tang Xin 唐欣. 'Shige ye shi tiaozhan: Yi Sha shige jianlun' 诗歌也是挑战一一伊 沙诗歌简论 (Poetry as a challenge: on Yi Sha's poetry). Lanzhou daxue xuebao 兰州大学学报 (Journal of Lanzhou University), no. 6, 2006, pp. 15-20. . Shuohua de shige 说话的诗歌 (The speaking poetry). Beijing: Zhongguo shehui kexue chubanshe, 2012. . 'Tianhua luanzhui: Yi Sha jinzuo jiedu' 天花乱芏——伊沙近作读解 (Flowers cascading from the sky: Yi Sha's recent poems). Hongyan 红岩 (Red cliff), no. 1, 2014, pp. 164-66.

. 'Chuzuche shiguo yizuo wuming daqiao-Xin shiji shidian' 出租车驶过一座 无名大桥——新世纪诗典 (The cab rolls cross a nameless bridge: New century poetry classics). Qinghai hu 青海湖 (Qinghai Lake), No. 8, 2015, p. 41.

Tao Naikan and Simon Patton. 'Introduction: There Is Style in the Blood'. Yi Sha. Starve the Poets!, trans. Simon Patton and Tao Naikan. Northumberland: Bloodaxe Books, 2008, pp. 9-16.

The blog of Chang'an Poetry Festival 长安诗歌节的博客： http://blog.sina.com.cn/changanshigejie, accessed 25 March 2018. 
van Crevel, Maghiel. Chinese Poetry in Times of Mind, Mayhem and Money. Leiden: Brill, 2008.

. 'Rejective Poetry? Sound and Sense in Yi Sha'. In Maghiel van Crevel, Tian Yuan Tan and Michel Hockx, eds. Text, Performance, and Gender in Chinese Literature and Music Essays in Honor of Wilt Idema. Leiden: Brill, 2009. . 'Underground Poetry in the 1960s and 1970s'. Modern Chinese Literature, Vol. 9, No. 2, Fall 1996, pp. 169-219.

. 'Walk on the Wild Side: Snapshots of the Chinese Poetry Scene'. MCLC Resource Centre, 2017. http://u.osu.edu/mclc/online-series/walk-on-the-wildside/, accessed 9 September, 2019.

Veg, Sebastian. Minjian: The Rise of China's Grassroots Intellectuals. New York: Columbia University Press, 2019.

Wang Shiqiang 王士强. 'Kui: “xiandai shi” de tuizhu zhe yu jisan di' 《葵》: “现代 诗” 的推助者与集散地 (Sunflower: a booster and distribution centre of 'modern poetry'). Lingnan shifan xueyuan xuebao 岭南师范学院学报 (Journal of Lingnan Normal University), Aug. 2017, Vol. 38, No. 4, pp. 55-60.

Wang Xiaoming 王晓明. 'Fanyi de zhengzhi—cong yige cemian kan 80 niandai de fanyi yundong' 翻译的政治一从一个侧面看 80 年代的翻译运动 (The politics of translation: a perspective to view the translation movement in the 1980s), http://www.guancha.cn/WangXiaoMing/2018 $06 \quad 23$ 461091 1.shtml, accessed 4 October 2019.

Wang Youwei 王有尾. 'Chang'an shige jie' 长安诗歌节 (Chang'an poetry festival). Shichao 诗潮 (Poetic tide), No. 6, 2016, p. 61.

Webby, Elizabeth. ed. The Cambridge Companion to Australian Literature. Cambridge: Cambridge University Press, 2006.

'Wenxue fanyi shi yao zhongyu yuanwen haishi suixing chuangzuo' 文学翻译是要 忠于原文还是随性创作 (Literary translation: faithful to the original or free creation?). Xi'an ribao 西安日报 (Xi'an daily), http://epaper.xiancn.com/xarb/html/2016-01/06/content 405783.htm, accessed 20 May, 2019.

Wu, Cuncun. "It Was I Who Lured the Boy": Commoner Women, Intimacy and the Sensual Body in the Song Collections of Feng Menglong (1574-1646)'. Nan Nü, 
No. 12, 2010, pp. 311-43.

Xi Chuan 西川. ‘Sikao bi manma geng zhongyao' 思考比谩骂更重要 (Thinking is more important than abuse). In Yang Ke 杨克, ed. 1999 Zhongguo xinshi nianjian 1999 中国新诗年鉴 (1999 yearbook of China’s new poetry), Guangzhou: Guangzhou chubanshe, 2000, pp. 537-40.

. 'Snow' 雪, trans. Tao Naikan and Tony Prince. The Poetry International Website: $\quad$ https://www.poetryinternational.org/pi/poem/15643/auto/0/0/XiChuan/Snow/en/nocache, accessed 6 August 2019.

Xi Du 西渡. 'Dangdai shige de richanghua yundong-cong Wang Xiaolong, Han Dong dao Luo Yihe' 当代诗歌的日常化运动一一从王小龙、韩东到骆一禾 (The Movement of returning to everyday life: from Wang Xiaolong, Han Dong to Luo Yihe). Jiefangju yishu xueyuan xuebao 解放军艺术学院学报 (Journal of PLA Academy of Art), No. 1, 2016, pp. 151-57.

'Xin shiji shidian quanqiu Zhongwen shige shili bang (2019.8.31 gengxin)' 《新世纪 诗典》全球中文诗歌实力榜（2019.8.31 更新）(The New Poetry Classics strength list of global Chinese poetry, updated 31 August 2019). In Yi Sha's weibo:

https://www.weibo.com/1218293911/I4Oqdc4dR?type=comment\#_rnd1569498 407443, accessed 26 September 2019.

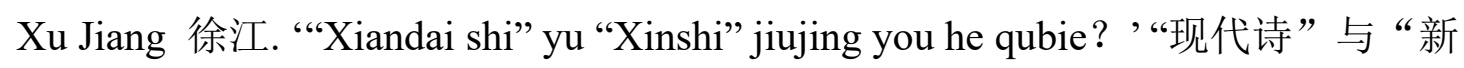
诗” 究竟有何区别? (What is the real difference between 'modern poetry' and 'new poetry'?), http://book.ifeng.com/a/20150617/15821 0.shtml\#, accessed 27 April 2019.

Xu Weinan 徐蔚南. Minjian wenxue 民间文学 (Folk literature). Shanghai: Shijie shuju, 1927.

Xu Ying 许荣. 'Shiyi de "wutuobang”- - tanfang Chang'an shigejie muqian muhou' 诗意的 “乌托邦” ——探访长安诗歌节幕前幕后 (A poetic utopia: before and behind the scenes of Chang'an Poetry Festival). Shidai renwu 时代人物 (Times figure), No. 6, 2011, pp. 82-85. 
Yan Li 严力, Yi Sha 伊沙 and Ma Fei 马非. Yihang cheng san 一行乘三 (A line by three). Xining: Qinghai renmin chubanshe, 1995.

Yang Ke 杨克, ed. 1998 Zhongguo xinshi nianjian 1998 中国新诗年鉴 (1998 yearbook of China's new poetry). Guangzhou: Huacheng chubanshe, 1999. , ed. 1999 Zhongguo xinshi nianjian 1999 中国新诗年鉴 (1999 yearbook of China's new poetry). Guangzhou: Guangzhou chubanshe, 2000. , ed. 2000 Zhongguo xinshi nianjian 2000 中国新诗年鉴 (2000 yearbook of China's new poetry). Guangzhou: Guangzhou chubanshe, 2001.

Yang Tianyu 杨天宇. Liji yi zhu, shang 礼记译注, 上 (Book of Rites with translations and notes, vol. I). Shanghai: Shanghai guji chubanshe, 1997.

Yeh, Michelle. Modern Chinese Poetry: Theory and Practice since 1917. New Haven: Yale University Press, 1991.

. 'Contemporary Chinese Poetry Scenes'. Chicago Review, 39, 3-4, 1993, pp. 279-83.

. 'The "Cult" of Poetry in Contemporary China'. The Journal of Asian Studies, Vol. 55, No. 1, February 1996, pp. 51-80.

奚密, ‘Chayi de youlü-dui Yuwensuo'an de yige huixiang' 差异的忧虑—— 对宇文所安的一个回响 (The anxiety of difference: a rejoinder to Stephen Owen). Zhong wai wenhua yu wenlun 中外文化与文论 (Chinese-foreign cultures \& literary theories), No. 2, 1997, p. 63.

. 'Anxiety \& Liberation: Notes on the Recent Chinese Poetry Scene.' World Literature Today, Vol. 81, No. 4, Inside China, July-August, 2007, pp. 28-35.

Yi Sha 伊沙. Esi shiren 饿死诗人 (Starve the poets). Beijing: Huaqiao chubanshe, 1994.

. Yezhong zhi ge 野种之歌 (Songs of a bastard). Xining: Qinghai renmin chubanshe, 1999.

. Wo zhongyu lijie le ni de jujue 我终于理解了你的拒绝 (I eventually understand your refusal). Xining: Qinghai renmin chubanshe, 1999. . Selected Poems of Yi Sha 伊沙短诗选, trans. Denis Mair 梅丹理 and Ouyang 
Yu 欧阳昱. Hong Kong: Yinhe chubanshe, 2003.

. Wo de yingxiong 我的英雄 (My hero). Shijiazhuang: Hebei jiaoyu chubanshe, 2003.

. Yi Sha shixuan 伊沙诗选 (Yi Sha's poems). Xining: Qinghai renmin chubanshe, 2003.

. Tang 唐 (Tang). Melbourne: Otherland Publishing, 2004.

. Che guo Huanghe 车过黄河 (Crossing the Yellow River). New York: Walt Whitman Literature Fund, 2006.

. Linghun chuqiao 灵魂出空 (The soul leaving the body). Beijing: Zhongguo wenlian chubanshe, 2008 .

. Starve the Poets! Trans. Simon Patton and Tao Naikan. Northumberland: Bloodaxe Books, 2008.

. Niaochuang 尿床 (Bed-wetting). Taipei: Tonsan Books, 2009.

.Wuti shiji 无题诗集 (Untitled poems). Foshan: Ganlu shikan, 2010.

. Relang zhong de lixiangguo 热浪中的理想国 (Heatwave in utopia).

Unofficial publication, 2011.

. Landeng 蓝灯 (Blue lamp). Hong Kong: Yinhe chubanshe, 2011.

. Shiguo bukan huishou yue ming zhong 诗国不堪回首月明中 (It is unbearable

to recall the poetry nation under the bright moon). Taipei: Showwe Information, 2011.

. Zhongguo xiandai shilun 中国现代诗论 (On modern Chinese poetry). Taipei:

Showwe Information, 2011.

. 'Shiji mo: shiren weihe yao dazhang' 世纪末: 诗人为何要打仗 (End of the century: why the poets are going to war). In Yi Sha 伊沙. Zhongguo xiandai shilun 中国现代诗论 (On modern Chinese poetry). Taipei: Showwe Information, 2011, pp. 247-60.

. 'Wo suo lijie de xiabanshen he wo' 我所理解的下半身和我 (The Lower

Body and myself to my understanding). In Yi Sha 伊沙, Zhongguo xiandai

shilun 中国现代诗论 (On modern Chinese poetry), Taipei: Showwe

Information, 2011, pp. 233-35. 
. 'Yi Sha lun’ 伊沙论 (On Yi Sha). In Yi Sha 伊沙. Zhongguo xiandai shilun 中国现代诗论 (On modern Chinese poetry). Taipei: Showwe Information, 2011, pp. 68-104.

. 'Zhongguo shiren de xianchang yuansheng_-2001 wang shang lunzheng toushi' 中国诗人的现场原声—-2001 网上论争透视 (The live soundtrack of Chinese poets: an insight into online polemics in 2001). In Yi Sha 伊沙, Zhongguo xiandai shilun 中国现代诗论 (On modern Chinese poetry), Taipei: Showwe Information, 2011, pp. 146-62.

. 'Zishang zixi (1988-1992)’ 自赏自析 (1988-1992) (Self-appreciation and selfanalysis: 1988-1992). In Yi Sha 伊沙, Zhongguo xiandai shilun 中国现代诗论 (On modern Chinese poetry), Taipei: Showwe Information, 2011, pp. 178-92.

. 'Zuowei shijian de "Penfeng lunzheng": zai Hengshan Shihui "Jiushi niandai hanyu shi yanjiu luntan” shang de fayan” 作为事件的 “盘峰论争” ——在衡 山诗会 “九十年代汉语诗研究论坛” 上的发言 ('Panfeng Polemic' as an incident: a speech on the 'Forum for studies of Chinese poetry in the nineties' at Hengshan Poetry Conference). In Yi Sha 伊沙. Zhongguo Xiandai Shilun 中国 现代诗论 (On modern Chinese poetry). Taipei: Showwe Information, 2011, pp. 279-83.

. Shijie de jiaoluo 世界的角落 (Corners of the world). Xi'an: Shaanxi shifan daxue chubanshe, 2011.

.Xing 行 (Travelling). Unofficial publication, 2011.

. Meng, diyi juan 梦, 第一卷 (Dreams, vol. 1). Xining: Qinghai renmin chubanshe, 2012.

. 'Daidao taiyang dengbuji le, women cai nufang-Bukaosiji yishi xiaoji' 待到 太阳等不及了, 我们才怒放——布考斯基译史小记 (We did not bloom until the sun disgusts with waiting: a brief note on our history of translating Bukowski). In Charles Bukowski 查尔斯 - 布考斯基. Ganjing laotou: Bukaosiji shixuan 干 净老头: 布考斯基诗选 (A clean old man: selected poems of Charles Bukowski), trans. Yi Sha 伊沙 and Lao G 老 G. Unofficial publication, 2012, pp. 193-204. . '9/11 Psychological Report', trans. Heather Inwood. Chinese Literature Today, 
Vol. 2, No. 2, 2012, p. 13.

· ‘9.11 xinli baogao' 9.11 心理报告 (9/11 psychological report). Chinese Literature Today, Vol. 2, No. 2, 2012, p. 13.

, ed. Xin shiji shidian, diyi ji 新世纪诗典, 第一季 (New century poetry classics, vol. 1), Hangzhou: Zhejiang wenyi chubanshe, 2012. , ed.Xin shiji shidian, dier ji 新世纪诗典, 第二季 (New century poetry classics, vol. 2), Beijing: Jiuzhou chubanshe, 2014.

. Di shui cheng bing 滴水成冰 (Dripping water becoming ice). Chongqing:

Chongqing daxue chubanshe, 2015.

. 'Kouyushi lunyu’ 口语诗论语 (Analects of Colloquial Poetry). Shichao 诗潮

(Poetic tide), No. 2, 2015, p. 120-23.

. Meng, dier juan 梦, 第二卷 (Dreams, vol. 2). Xining: Qinghai renmin chubanshe, 2015.

, ed. Xin shiji shidian, disan ji 新世纪诗典, 第三季 (New century poetry classics, vol. 3), Hangzhou: Zhejiang wenyi chubanshe, 2015.

, ed. Xin shiji shidian, disi ji 新世纪诗典, 第四季 (New century poetry classics, vol. 4), Hangzhou: Zhejiang renmin chubanshe, 2016.

, ed. Xin shiji shidian, diwu ji 新世纪诗典, 第五季 (New century poetry classics, vol. 5), Hangzhou: Zhejiang renmin chubanshe, 2016. , ed. Xin shiji shidian, diliu ji 新世纪诗典, 第六季 (New century poetry classics, vol. 6), Hangzhou: Zhejiang renmin chubanshe, 2018. , ed.Xin shiji shidian, diqi ji 新世纪诗典, 第七季 (New century poetry classics, vol. 7), Beijing: Zhongguo qingnian chubanshe, 2018

. 'Police Car, Poet, Snow'雪天里的几种事物, trans. Simon Patton, Tao Naikan and Michael M. Day. The Poetry International Website: https://www.poetryinternational.org/pi/poem/10097/auto/0/0/Yi-Sha/POLICECAR-POET-SNOW/en/tile, accessed 6 August 2019. . 'Zhongguo dangdai shige: cong “quanqiu hua” shuo kai qu' 中国当代诗歌: 从“全球化”说开去 (Contemporary Chinese poetry: starting from 'globalisation'). Jintian 今 天 (Today) website, 16 January 2009. 
https://www.jintian.net/today/?action-viewnews-itemid-3051, accessed 20 June 2019.

Yi Sha 伊沙 and Lao G 老 G, eds and trans. Dang ni lao le: Shijie mingshi 100 shou xinyi 当你老了：世界名诗 100 首新译 (When you are old: new translations of 100 famous foreign poems). Xining: Qinghai renmin chubanshe, 2013.

. Laizi shijian de dahai: Ying Mei mingshi 100 shou xinyi 来自时间的大海: 英 美名诗 100 首新译 (From the oceans of time: new translations of 100 famous British and American poems). Xining: Qinghai renmin chubanshe, 2014.

Yi Sha, Shu Cai and Yang Xie. Poems of Yi Sha, Shu Cai \& Yang Xie, trans. Ouyang Yu. Newtown NSW: Vagabond Press, 2012.

'Yi Sha "Xin shiji shidian” toupao: Shen Haobo "Mali de aiqing” yin reyi' 伊沙《新 世纪诗典》头炮: 沈浩波《玛丽的爱情》引热议 (The first bomb of Yi Sha's 'New Century Poetry Classics': Shen Haobo's 'Mary's love' causes hot discussion), 2011, http://www.poemlife.com/newshow-6102.htm, accessed 10 May 2018.

'Yong 28 nian shengming pinzhi dazao de shige diguo Shi cankao' 用 28 年生命品质 打造的诗歌帝国《诗参考》 (Poetry reference: A poetry empire built from 28 years quality life), http://blog.sina.com.cn/s/blog_7f083ea80102x5h5. html, accessed 1 November 2017.

Yu Jian 于坚. 'Shige zhi she de ying yu ruan: guanyu dangdai shige de lianglei yuyan xiangdu' 诗歌之舌的硬与软：关于当代诗歌的两类语言向度 (The hard and soft tongues of poetry: On two different directions in the languages of contemporary poetry). In Yang Ke 杨克, ed. 1998 Zhongguo xinshi nianjian 1998 中国新诗年鉴 (1998 yearbook of China’s new poetry). Guangzhou: Huacheng chubanshe, 1999, pp. 451-68.

. 'Dangdai shige de minjian chuantong' 当代诗歌的民间传统 (The minjian tradition of contemporary poetry). Dangdai zuojia pinglun 当代作家评论 (Review of contemporary writers), No. 4, 2001, pp. 84-90.

. 'Du Fuluosite' 读弗洛斯特 (Reading Robert Frost). Zhonghua shiku: Yu Jian 
shixuan 中华诗库：于坚诗选 (Collections of Chinese poetry: Yu Jian), https://www.shigeku.org/shiku/xs/yujian.htm\#15, accessed 6 October 2019.

Yuen Wai, Helena: “A Journey across Rivers and Lakes: A Look at the Untranslatable Jianghu in Chinese Culture and Literature" [online article], $452^{\circ} \mathrm{F}$. Electronic journal of theory of literature and comparative literature, 7, 2012, pp. 58-71. http://www.452f.com/pdf/numero07/07 452f-mono-helena-yuen-wai-orgnl.pdf, accessed 24 September 2017.

Yuzhi 愈之. 'Lun minjian wenxue' 论民间文学 (On folk literature). Funü zazhi 妇 女杂志 (Women’s magazine), Vol. 7, No. 1, 1921, pp. 32-36.

Zhang Jian 张剑. ‘Jinsibao, Haojiao yu kangyi wenhua' 金斯堡、《嚎叫》与抗议 文化 (Ginsberg, Howl and the culture of protest), http://epaper.gmw.cn/zhdsb/html/2012-08/08/nw.D110000zhdsb_20120808_117.htm, accessed 7 October 2019.

Zhang, Lijia. 'Mad Dog: The Legend of Chinese Poet Guo Lusheng'. Mānoa, Vol. 14, No. 1, 2002, pp. 105-113.

Zhang Qinghua 张清华. 'Yici zhenzheng de shige duihua yu jiaofeng—“shiji zhi jiao: Zhongguo shige chuangzuo taishi yu lilun jianshe yantaohui” shuyao' — 次真正的诗歌对话与交锋——世纪之交：中国诗歌创作态势与理论建设” 述要 (A real poetic dialogue and battle: an account of 'Turn of the century: a symposium on the creation tendency and theoretical construction of Chinese poetry'). Shi tansuo 诗探索 (Poetry explorations), No. 2, 1999, pp. 68-77.

Zhang Zao 张柊. 'Gen Ciweitayewa de duihua' 跟茨维塔耶娃的对话 (In reply to Marina Tsvetaeva), https://www.douban.com/group/topic/72990797/, accessed 12 December 2019.

Zhao Yiheng 赵毅衡. “Xushi” haishi “xushu”?-yi ge buneng zai “quanyi” xiaqu de shuyu hunluan” “叙事” 还是 “叙述” ? - — 一个不能再 “权宜”下去的 术语混乱 ('Narrative' or 'narration'?: a terminology confusion that can no longer be 'expedient'). Waiguo wenxue pinglun 外国文学评论 (Foreign literature review), No. 2, 2009, pp. 228-32.

Zhong Dao 中岛, ed. Yi Sha zhege gui 伊沙这个鬼 (Yi Sha the devil). Beijing: Shi 
cankao, 1998.

. 'Zong xu’ 总序 (General preface). In Yi Sha 伊沙. Tang 唐 (Tang).

Melbourne: Otherland Publishing, 2004.

Zhong Youmin 钟优民. Xin yuefu shipai yanjiu 新乐府诗派研究 (A study of new Yuefu poetry Group). Shenyang: Liaoning daxue chubanshe, 1997.

Zhou Lunyou 周伦佑. 'Disandai shilun 第三代诗论' (On the poetry of the Third Generation). Conference article at National Poetic Theory Symposium in Yangzhou, 1988. http://www.yuanliuw.com/html/2013-01/40461.html, accessed 30 June 2016

Zhou Zan 周瓒. Touguo shige xiezuo de qianwangjing 透过诗歌写作的潜望镜 (Through the periscope of poetic writing). Beijing: Shehui kexue wenxian chubanshe, 2007. 